\title{
Parada Billings
}

Ana Carolina Ayres Gimenez 

Universidade de São Paulo

Faculdade de Arquitetura e Urbanismo

Ana Carolina Ayres Gimenez

Parada Billings

São Paulo | 2019 

Ana Carolina Ayres Gimenez

Parada BIllings

Dissertação de mestrado apresentada ao Programa de Pós-Graduação de Arquitetura e Urbanismo da Faculdade de Arquitetura e Urbanismo da Universidade de São Paulo como parte dos requisitos para a obtenção do título de Mestre em Arquitetura e Urbanismo.

Área de concentração

Paisagem e Ambiente

Orientador

Prof. Dr.Eugenio Queiroga

São Paulo | 2019 
Autorizo a reprodução e divulgação total ou parcial deste trabalho, por qualquer meio convencional ou eletrônico, para fins de estudo e pesquisa, desde que citada a fonte.

Email da autora: acagimenez@gmail.com

Exemplar revisado e alterado em relação a versão original, sob responsabilidade do autor e anuência do orientador. O original se encontra na sede do Programa.

São Paulo, 11 de outubro de 2019.

\section{Catalogação na Publicação}

Serviço Técnico de Biblioteca

Faculdade de Arquitetura e Urbanismo da Universidade de São Paulo

Gimenez, Ana Carolina Ayres

Parada Billings / Ana Carolina Ayres Gimenez; orientador Eugenio Fernandes Queiroga. - São Paulo, 2019.

274.

Dissertação (Mestrado) - Faculdade de Arquitetura e Urbanismo da Universidade de São Paulo. Área de concentração: Paisagem e Ambiente.

1. Paisagem. 2.Espaço Público. 3.Reservatório Billings. 4.Lazer e Tempo Livre. I.Queiroga, Eugenio Fernandes, orient. II.Título.

Elaborada eletronicamente através do formulário disponivel em: <http://www.fau.usp.br/fichacatalografica/> 



\section{Agradecimentos}

Inicialmente gostaria de agradecer ao orientador Eugenio que me deu apoio nos momentos mais difíceis, com muita leveza e confiança, ajudando a recolocar esse trabalho "no mundo". Sua orientação preciosa, leitura atenta e auspiciosa, tudo isso feito com perspicácia e bom humor foram fundamentais para a existência dessa dissertação.

Agradeço ainda:

Ao Ivar, subprefeito do Riacho Grande, que além de portar memórias e histórias do Riacho, me abriu o canal com as famílias dos colonos italianos;

Aos vivenciadores e técnicos, que me ajudaram compartilhando suas experiências e conhecimentos, em especial a Ferruge e Tim, que dedicaram generosamente seu tempo diversas vezes às nossas conversas,

À Melissa Matsunaga, que além da importante pesquisa de mestrado, me auxiliou diretamente na entrada em campo, dando informações valiosas sobre os moradores que entrevistei no Cantinho do Céu,

À Luciana Ferrara, que desde a graduação, me dá atalhos no território dos "mananciais",

À Renata Moreira, que me ajudou compartilhan- do seus contatos e conhecimento em recursos hídricos, e com seu rigor habitual indiretamente me fez ter certeza de qual seria o lugar deste trabalho. Às amigas Juliana Braga, Mariana Luze Vanessa Moon, pela leitura, revisão, tradução e organização da bibliografia,

Aos amigos Roberto e Maíra, do três design, pelo projeto gráfico e diagramação,

Aos professores Alexandre Delijaicov e Paulo Pellegrino pelas contribuições realizadas na banca de qualificação, mais especialmente ao Alexandre que me acendeu uma luz: "escute as fontes primárias", sendo ele próprio uma delas,

Ao Rafael, meu filho, que fez com que tudo fosse mais complexo e divertido,

A família, Laura, Antônio, Maria Lucia que se dedicaram com afinco aos cuidados com o neto, nos momentos de trabalho mais intenso.

Finalmente em especial, ao companheiro Michel, cujo apoio incondicional, mesmo no momento mais turbulento da sua vida, foi fundamental para o percurso que aqui se encerra. 

...Nosso pai não voltou. Ele não tinha ido a nenhuma parte. Só executava a invenção de se permanecer naqueles espaços do rio, de meio a meio, sempre dentro da canoa, para dela não saltar, nunca mais. A estranheza dessa verdade deu para estarrecer de todo a gente...

\section{Guimaraes Rosa}

A terceira margem do rio 


\section{Resumo}

O ano de 1927 é a data marco da fundação da Billings. De lá para cá a represa atravessou os anos desempenhando papéis variados, tendo sido privilegiada a finalidade técnico-econômica da utilização de seus recursos. Esse trabalho se insere no âmbito dos estudos culturais e pretende contribuir para o fortalecimento de um discurso em que a represa apareça em suas outras dimensões, especialmente àquelas inseridas no âmbito lúdico-recreativo de uso coletivo, privilegiando o uso das margens e águas para lazer. Focou-se em duas situações distintas desse tipo de apropriação: o Riacho Grande, no município de São Bernardo do Campo, e o Parque Linear Cantinho do Céu no município de São Paulo. O estudo se realizou a partir da associação entre pesquisa documental e de campo, e se dividiu em duas partes: na primeira focamos em dados primários e secundários. Com o apoio bibliográfico identificamos os principais processos de urbanização e incorporação das margens da represa às dinâmicas da Região Metropolitana de São Paulo para contextualizar as narrativas tratadas na segunda parte, onde analisou-se o lazer na represa na perspectiva de alguns dos seus usuários. Buscou-se identifi- car quais os aspectos do espaço são valorizados quando escolhas mais livres estão presentes, ou seja, quando as pessoas, já liberadas de suas obrigações escolhem passar seu tempo na represa, buscando assim iluminar outros significados para a paisagem da Billings.

Palavras-chave: Paisagem. Espaço Público. Reservatório Billings. Lazer e tempo livre. 


\section{Abstract}

The year 1927 marks the milestone for the founding of the Billings. Since then, the dam has played several roles through the years, with priority given to the technical and economic uses of its resources. This study is part of a cultural study and it aims to contribute to the strengthening of a discourse in which the dam reveals itself in other dimensions, especially in the recreational sphere of collective use, favoring the use of its waters and waterfront for leisure. The study focuses on two distinct types of appropriation: the Riacho Grande, in the municipality of São Bernardo do Campo and the Cantinho do Céu Linear Park in the city of São Paulo. The study is based on the amalgamation of documentary and field research and is divided into two parts: in the first part we focus on primary and secondary sources and with bibliographic support we identify the main processes of urbanization and incorporation of the waterfront to the dynamics of the Metropolitan Region of São Paulo. This part seeks to contextualize the narratives addressed in the second part of the paper. In the second part we analyze the leisure activities in the dam from the perspective of some of its users. The study seeks to identify which aspects of the space are valued at the moment when freedom of choice is present, that is, when people, free from their obligations choose to spend their time in the dam, thus seeking to illuminate other meanings for the landscape of the Billings.

Keywords: Landscape. Public Space. Billings Reservoir. Leisure and free time 


\section{Sumário}

19 Introdução

27 1. Águas para que $(\mathrm{m})$ ?

27 Rio, Represa, Residência

40 Planos $x$ ações

47 2. Riacho Grande

47 O percurso

48 História, memórias e Paisagem

63 Projeto de Urbanização

71 3. Cantinho do Céu

71 O percurso

74 História, memórias e Paisagem

81 Projeto de Urbanização

85 4. Incorporando princípios da Antropologia no Olhar do Arquiteto

85 Etnografia como método de pesquisa em Arquitetura

90 O campo

93 5. Lazer na represa

93 A represa no olhar de seus vivenciadores:

Depoimentos e experiências

\section{Conclusão}

129 Bibliografia

135 Anexo

141 Apêndice 


\section{Introdução}

Ao longo do século XX, São Paulo assistiu ao progressivo apagamento da memória de usos e funções que se estabeleciam na água. Num intervalo curto de tempo, os rios se tornaram "urbanos" e nessa transformação os mesmos foram afastados do cotidiano da população. Alvo de obras de engenharia que transformaram rios em represas, água em potencial hidrelétrico, em pouco mais de cinquenta anos os recursos hídricos foram sendo identificados em larga medida com produção de água e energia, indústria, esgoto, saneamento e enchentes.

Na represa Billings os processos que levaram a significação de suas águas em seu sentido técnico são bastante claros. Procurou-se descrevê-los no capítulo 1 dessa dissertação, onde foi localizado no tempo e no espaço o projeto da Serra, a formação da represa e suas transformações ao longo dos anos. Avaliou-se as legislações incidentes, seu papel na desvalorização imobiliária dos terrenos contíguos a represa e a inserção das margens e córregos que desaguam em sua bacia na dinâmica do auto provimento de habitação pela população de baixa renda da região metropolitana de São Paulo. Essa dinâmica vem sendo estudada por uma linha de pesquisa bastante consagrada na Faculdade de Arquitetura e Urbanismo da Universidade de São Paulo, portanto não corresponde aos objetivos dessa pesquisa nos aprofundar na temática, apenas circunscrevê-la de forma a contextualizar esta pesquisa.

Este capítulo se apoia em dois tipos de bibliografia: duas teses fundamentais escritas na década de 70 e 80 que versam sobre a estruturação da Grande São Paulo e o papel dos recursos hídricos nesse processo ${ }^{1}$ e outra que procura aproximar o olhar tanto no tempo como no espaço para então se deter em porções menores do território. A ideia é que a Billings pudesse ser estudada a partir de diferentes escalas: uma geral, outra local e outra ainda mais aproximada, presente nos capítulos seguintes, que incorpora a narrativa dos indivíduos que vivem a experiência dos espaços da represa e na represa. Ao propor esse estudo em diferentes escalas, comum ao campo disciplinar da arquitetura, busca-se entender como os processos mais gerais que envolvem legislação e políticas públicas (ou ausência delas) dialogam ou se contrapõe às narrativas dos atores

1. SEABRA (1987), LAGENBUCH (1971). 
sociais. Essa forma de abordagem, como se verá adiante, incorpora princípios da antropologia urbana.

No primeiro capítulo aborda-se a questão da insuficiência hídrica de São Paulo e sua dependência de outras bacias explicitada durante a crise de abastecimento de 2015. A escassez de água em São Paulo já era conhecida pelos planos estaduais para o setor ${ }^{2}$, no entanto, o Governo do Estado, através de discursos de seu governador e do presidente da Sabesp ${ }^{3}$, procurou minimizar a crise de gestão atribuindo excessivo peso a condições climáticas desfavoráveis. Naquele momento abria-se uma oportunidade em discutir o papel estratégico da represa Billings e como as vazões de retirada de sua bacia poderiam ser ampliadas para abastecimento de água na Região Metropolitana de São Paulo.

Essa discussão esteve presente no seminário "a cidade e as águas" que aconteceu em São Paulo em setembro de $2017^{4}$ ocasião em que vários palestrantes, em especial o arquiteto Ricardo Toledo e a geógrafa Stela Goldenstein, defenderam a necessidade de se adotar novos enfoques para a gestão das águas urbanas de São Paulo particularmente no sistema Tietê-Pinheiros-Billings. A pergunta que muitos de se fizeram em 2015 sobre a qualidade da água da represa para abastecimento público se recolocou no seminário: Como aumentar a produção de água de boa qualidade na represa? Qual seria o horizonte temporal para que isso se realize? O consenso entre os presentes foi que a falta de diálogo e articulação entre os sistemas de saneamento e políticas de uso e ocupação do solo estariam atrasando essa solução.

2. No ano de 2004 o Plano Estadual de Recursos Hídricos apontava que a demanda na Regiāo Metropolitana de São Paulo era 4,32 vezes maior que a oferta existente, colocando a RMSP em posição de extrema dependência de bacias vizinhas.

3. Geraldo Alckmin e Jerson Kelman, respectivamente

4. Seminário organizado pelo instituto Insper em parceria com Arq cidade.
Não agem de maneira articulada: as empresas ou concessionárias de coleta e tratamento de esgotos, Estado - responsável pela drenagem dos rios Tietêe Pinheiros, municipios - responsável pela drenagem dos córregos e contenção de erosão, proprietários de terras nas áreas de mananciais (majoritariamente em áreas privadas) e as empresas concessionárias de remoção de resíduos sólidos. Essa desarticulação impõe enormes restrições à reversão do quadro crítico em que a represa se encontra. O primeiro capítulo procura assim apresentar o panorama atual com dados dos planos estaduais de recursos hídricos e informações coletadas com técnicos da área.

É certo que a crise de 2015 foi importante para uma mudança de status da represa, ao menos simbolicamente: de "lagoa de estabilização" passou a ser chamada de "caixa d'água" ${ }^{\text {. Embora esse }}$ status seja em parte um "malabarismo político" diante da severa crise de abastecimento de água em São Paulo naquele ano, colocou em evidência a necessidade de enfrentar em grande escala o problema de implantação de infraestrutura sanitária nas margens represa.

$\mathrm{Na}$ avaliação desses processos, no entanto, escapa um componente importante da análise: quais seriam os aspectos simbólicos que permaneceriam diante dos mesmos? Qual seria a melhor maneira de identificá-los? E ainda: quais os efeitos dos processos gerais sobre porções menores do território? O procedimento adotado para essas investigações

5. O termo é usado por CONTRERAS (1997).Vinte anos antes, em 1977, a revista DAE afirmava: "Quanto ao reservatório Billings, esse corpo d'água se tem comportado por muitos anos como um sistema de tratamento para a maior parte dos esgotos de São Paulo (...) Em linhas gerais, os estudos mostram que o reservatório Billings está se comportando como uma lagoa anaeróbica no seu corpo principal entre Pedreira e o Summit Control (...). pp.40-41

6. "Billings é caixa-d'água de São Paulo, afirma presidente da Sabesp" em 15.01.2015 - Diário do Grande ABC e"Billings é a grande caixa d'água da cidade de São Paulo, diz Alckmin "em 30.01.2015 - Agência Estado. 
foi aprofundar o nível de análise para outras escalas.

O primeiro movimento de aproximação do olhar se apresenta nos capítulos 2 e 3, com a escolha de dois territórios de exploração: o Riacho Grande, no município de São Bernardo do Campo, usado por moradores da Grande São Paulo para passar os finais de semana e o Parque Linear Cantinho do Céu no município de São Paulo, executado como parte das obras de urbanização de favelas e que teve papel fundamental em aproximar os moradores do Grajaú das margens da represa. Para esses capítulos, procurou-se localizar os processos específicos de crescimento dos distritos desde a formação dos mesmos até os dias de hoje.

No Riacho Grande, ocupação originada de uma colônia de povoamento predominantemente de italianos, ao longo dos anos se configurou uma mancha7 de lazer próximo ao centro do distrito. Interessa particularmente entender como esse trecho da orla fluvial da Billings tornou-se "palco" do lazer metropolitano. Embora a destinação oficial fosse a ocupação por casas de veraneio de alto padrão, com uso bastante restrito, ao longo dos anos popularizou-se e tornou-se uma "praia" metropolitana, passando a ser chamado de Prainha. Embora seja um espaço deteriorado ambientalmente, em razão da qualidade das águas e do projeto de urbanização inadequado, é absolutamente vivo e pulsante do ponto de vista do uso para lazer.

No Cantinho do Céu, nome dado ao complexo formado pelos bairros Jd. Gaivotas, Parque Residencial do Lagos e Cantinho do Céu, se trata de um assentamento oriundo do processo irregular de ocupação da área de mananciais. Algumas particula-

7. As categorias mancha e pedaço foram formuladas por MAGNANI, 2012. Mancha seria o lugar de reunião de pessoas com determinado gosto cultural, mas que não se conhecem, dando lugar a encontros imprevistos. Já o pedaço é o lugar dos encontros entre pares conhecidos. As duas categorias serão exploradas no capítulo 4. ridades que serão explicitadas no desenvolvimento dessa dissertação irão explicar como uma Ação Civil Pública em 1997, cujo objetivo era por em prática a remoção do assentamento por completo, culminou, após longa negociação com a Promotoria, na readequação do assentamento com um número bem menor de remoções e implantação de um Parque Linear na beira da represa, intensamente utilizado pela população do entorno atualmente e com características de pedaço.

No capítulo 4 buscou-se construir bases de um método em que a análise do território e a caracterização dos processos mais amplos que incidem sobre o mesmo fossem o suporte para as narrativas exploradas no capítulo 5. A proposta desse capítulo é definir as formas de captar a experiência de alguns indivíduos sem que se perca a dimensão da cidade. Para tal incorpora a abordagem da Antropologia Urbana no intuito de auxiliar na organização e observação em campo para além da visão em voo de pássaro, metáfora comum aos arquitetos. Olhar para os espaços de encontro e troca na cidade a partir desse repertório pode fornecer subsídios para intervenções urbanas que dialoguem melhor com seus vivenciadores ${ }^{8}$.

A cidade vista através da ótica do lazer, algo recente no campo dos estudos antropológicos em São Paulo ${ }^{9}$, permite ao arquiteto enfocar a expe-

8. O termo é utilizado por PEREIRA (2006) no lugar de usuários. Como o autor, acreditamos que o termo expressa melhor a ideia de um agente participante na paisagem.

9. José Guilherme Cantor Magnani defende sua tese em 1982 com o título "Festa no pedaço: cultura popular e lazer na cidade" abrindo um campo de estudos sobre o lazer na metrópole. O campo da Antropologia Urbana paulista vem da linhagem de Eunice Durham e Ruth Cardoso, que Magnani fortaleceu e deu continuidade através de suas pesquisas, criação do Nucleo de Antropologia Urbana no final da década de 80 e formação de inúmeros pesquisadores através de orientaçōes de pós-graduação e iniciação científica. Sua pesquisa de doutorado, que desvenda as inúmeras redes de lazer em bairro periférico, foi fundamental para a legitimação da pesquisa em lazer na Universidade de Sāo Paulo. 
riência de estar no espaço público, tanto do ponto de vista do observador como do vivenciador. Ao se colocar no lugar onde as trocas acontecem, ao mesmo tempo em que as observa, ele participa, pois não está imune ao seu entorno. Para entender esse tipo de apropriação e uso da cidade, fazer parte do sistema de trocas é parte importante do processo. É nesse contexto, da interação com diferentes e entre diferentes no espaço público que se rompe a ideia da fragmentação e da individualização nos grandes centros urbanos.

Da ótica dos estudos da paisagem, que pressupõe a existência e interação ativa de quem a vê e a vivencia, a atenção ao cotidiano no ato de projetar, pode resultar em espaços mais plenos de significado e pertencimento. Assim, calibrar o olhar para o cotidiano das pessoas traz benefícios para o exercício profissional do arquiteto. As narrativas que aparecem no capítulo 5 auxiliam nesse processo ao apontar para outras versões sobre a Billings. Através da fala dos entrevistados, identificamos uma pluralidade de significados, experiências e apropriaçōes da represa.

As situações encontradas em campo apontaram para a existência de um sistema de espaços de lazer na represa seja por conexões e relações atuais, seja por conexões porvir, revelando-se um ambiente fértil para futuras investigações e projetos. Em confronto com a normativa ${ }^{10}$ e senso comum onde impera uma certa ideia de intocabilidade, exclusividade e restrição, a represa, ao revelar experiências concretas de um lazer diverso, democrático e potente cumpre um papel fundamental na afirmação dessa função pública na metrópole.

10. Refiro-me as Leis n. 898/1975 e 1.172/96 que previam índices urbanísticos como taxa de ocupação, densidade e indice de elevação compatíveis com usos nāo urbanos e muito abaixo daqueles praticados nos dois casos estudados nesta dissertação.

\section{Objetivo, percurso e procedimentos}

A pesquisa se propôs a investigar fraturas dentro de um processo tecnicização das margens e águas da represa Billings com o objetivo de iluminar outros significados para a Paisagem. O questionamento se colocou em torno de 3 eixos principais:

1. Como enxergar a represa para além dos conflitos de uso? Com quais "lentes"?

2. Como considerar as potencialidades deste patrimônio social para além de sua finalidade econômica, seja ela para produção energética, abastecimento de água ou moradia?

3. O represamento da Billings, a reversão do Pinheiros, bombeamento e uso econômico de suas águas contribuíram para a transformação de natureza enquanto espaço mediado pela técnica. Mas e as demais dimensões que existiriam e subsistiriam nesse processo?

Durante os anos de 2017-2018 foram feitas visitas à campo em busca de situações em que as pessoas estivessem na represa para passar o tempo. Esse recorte adotou a premissa de que estar na represa era uma escolha e não uma imposição. O olhar distante, impregnado da ideia de que pessoas só estariam na Billings por ter sido o lugar que "sobrou", seja por não terem conseguido uma boa oportunidade de venda, ou por ter sido o lugar possivel para construírem suas casas, foi sendo substituído por uma imagem da represa como lugar de estar.

Essa primeira abordagem ${ }^{11}$ guardou um certo distanciamento e não contemplou a perspectiva

11. Foram feitas visitas de reconhecimento do território em alguns braços da represa, com paradas em pontos específicos, mas sem estabelecimento de contato ou vínculos com pessoas. Essas visitas aconteceram de modo mais sistemático entre fevereiro e abril de 2018, quando se preparou um relatório fotográfico para o memorial de qualificação. 
dos usuários vivenciadores. Teve como resultado o mapeamento de algumas experiências de uso das margens e águas para fins de lazer.

Para um contato mais íntimo com o objeto de pesquisa, optou-se na sequência por restringir o recorte para duas situações representativas desse tipo de apropriação, tendo a escolha sido feita por critério de representatividade e contemporaneidade dos estudos de caso em diferentes escalas: um estudo em escala local, Cantinho do Céu, e outro em escala metropolitana, Prainha. Ambos espaços foram objeto de projetos de urbanização no mesmo período, entre 2009-2010. Na "contramão" do processo metropolitano geral em que se tem uma perda de valor e uso dos espaços públicos e crescente privatização da vida na metrópole, esvaziamento de sentido simbólico de rios e represas, deter-se sobre dois casos pulsantes de uso público das margens da Billings conferem relevância à pesquisa. Ambos se encontram no compartimento abaixo da barragem Anchieta, que divide o "braço sujo" do "braço limpo"12. Essa separação física dos corpos hídricos visou a preservação da captação de água da Sabesp.

No Riacho Grande, antigo porto fluvial, identificou-se, uma mancha ${ }^{13}$ de lazer: restaurantes com cardápio dedicado a peixes e frutos do mar, lojas dedicadas a venda de produtos relacionados a pesca com varas de pescar, redes, etc., lojas dedicadas a venda de canoas e caiaques, boias, etc., além de marinas e estacionamento de veículos náuticos. $\mathrm{O}$ uso das águas e margens para atividades relacionadas a mancha se concentra predominantemente aos finais de semana, mas ocorre também em dias de semana, em "horário de expediente". Embora

12. Terminologia empregada por Ivar José de Souza, subprefeito do Riacho Grande em entrevista à autora.

13. Ver capítulo 4 ocorra em uma diversidade de situações ${ }^{14}$, é mais concentrada na Prainha. São pessoas que vivem a represa em outro registro, algumas delas no tempo da espera e contemplação, como que em oposição ao fluxo frenético dos grandes eixos viários que cruzam as águas. Outras o reproduzem na água em suas motos aquáticas, muitas vezes desrespeitando regras da Marinha, colocando em risco a própria vida e a vida de outras pessoas ${ }^{15}$.

No Cantinho do Céu, parque executado como parte da reurbanização de três bairros do Grajaú durante o Programa de Mananciais entre os anos de 2008 e 2011 o que se verificou foi que o Parque se tornou um polo catalisador da relação dos bairro com a Billings e possibilita encontros e eventos dos moradores que se veem e se reconhecem nos passeios matinais e nos finais de semana, mas também se organizam em torno de ativismos variados cuja temática frequente é a represa ${ }^{16}$.

Embora os exemplos estudados constituam lugares de parada e estar na represa, a região ainda é, majoritariamente, uma zona de trânsito: das águas em direção a Cubatão, das águas que abastecem o ABC ou são transpostas para a Guarapiranga, das mercadorias que vêm e vão do porto de Santos, dos oleodutos que sobem a serra para abastecer os centros consumidores, da "periferia" que vai e volta do centro todos os dias circulando pelos bairros ditos "dormitórios". Duas ferrovias, duas rodovias e um anel rodoviário em operação. Seria ainda uma zona de passagem, nos termos de Langenbuch (1971)?

14. nos embarques das balsas entre Capivari e Riacho Grande, no dique da Anchieta e até nos braços mais distantes e tranquilos, em Taquecetuba e Bororé.

15. São muitos registros de acidentes com moto aquática na Billings e particularmente na Prainha, alguns links para ilustrar, verificar na bibliografia citaçōes de jornais.

16. A exemplo dos grupos Navegando nas Artes, Remada na Quebrada, Imargem, Unigraja, entre outros. 
Ao examinar quais outras dimensões e finalidades existem e subsistem na represa encontramos também outras respostas. Refletir sobre o sentido contemporâneo das margens e águas da Billings como espaços de uso e vivência do conjunto de cidades que estão no seu entorno e configuram a região metropolitana de São Paulo se constituiu então o objetivo da dissertação.

A estratégia adotada focou na observação direta e nas narrativas de alguns de seus usuários dentro de um recorte espacial definido, fornecendo pistas para abordagem em que a represa dê suporte a outras dimensões e finalidades que não simplesmente uma zona de passagem. Procurou-se através de princípios da Antropologia Urbana ${ }^{17}$ privilegiar a experiência de alguns de seus usuários, cujas narrativas se inserem num contexto maior em que se pode observar algumas regularidades tanto nos discursos como nas práticas espaciais, permitindo assim problematizar o discurso que homogeneíza a experiência na cidade e que no caso da Billings, não apresenta suas margens como um lugar de encontro, de troca e de estar. Sem a pretensão de construir "a verdade" sobre o lazer na Billings, optou-se por registrar algumas vivencias, para revelar a perspectiva de alguns de seus vivenciadores, como se relacionam com o lugar, como participam politicamente dos espaços. Esse tipo de registro fornece "pistas" para que o universo do pesquisado seja partilhado e contrastado com o universo do pesquisador, numa relação de troca onde o resultado pode indicar um novo caminho. Essas "pistas' constituem material fundamental para qualquer profissional que se dedique a pensar e projetar espaços urbanos.

Os assuntos que foram abordados nas entrevistas variaram de acordo com os entrevistados. Entre

17. Conceitos como mancha, pedaço e circuito, explicitados no capítulo 4 os vivenciadores, registrou-se as falas ${ }^{18}$ daqueles que surgiram como contato a partir da rede de "informantes" estabelecida tanto a partir das visitas à campo como a partir de outros pesquisadore ${ }^{19}$ que se detiveram sobre as mesmas áreas de estudo. No apêndice encontra-se a descrição de como, quando e onde foram feitas as entrevistas.

Optou-se também por incluir entrevistas com alguns técnicos envolvidos direta ou indiretamente na produção dos espaços estudados, não com a intenção de contrapor falas, mas para acrescentar informações às narrativas dos vivenciadores e contribuir qualitativamente com os assuntos abordados nos capítulos que antecedem as mesmas.

\section{Os vivenciadores}

1. Ferruge, Adolfo Duarte, 38 anos, administrador do Parque Linear Cantinho do Céu e dono da ONG meninos da Billings, que promove vivências náuticas na represa. Veio com os pais para o Cantinho do Céu com 8 anos e depois construiu sua casa no mesmo bairro.

2. Marcos Ramos, Enivo, 36 anos, Artista Plástico, grafiteiro, curador, galerista, morador do Grajaú até os 18 anos.

3. Wellington Neli da Silva, Tim, 38, Artista Plástico, sócio fundador do coletivo imargem, morador do Grajaú.

4. Claudio Ostheimer, marinheiro, família é proprietária do restaurante Nautilus, faz passeios de lancha na represa.

5. Lucia Cavinato, professora do estado aposen-

18. Quando autorizado e possivel, as falas foram gravadas e aparecem transcritas no anexo. Algumas conversas, no entanto, não foram gravadas ou por não terem sido autorizadas ou em alguns casos, para preservar um fluxo já iniciado ou uma situação mais difícil de registro do áudio.

19. Notadamente Simone Polli e Melissa Matsunaga. 
tada, 75 anos, ex. proprietária de escola particular no Riacho Grande.

6. Lucas Cavinato, 37 anos, proprietário da Marina Billings Jet Parking no Riacho Grande

7. Ivar José de Sousa, 63 anos, morador e Subprefeito do Riacho Grande.

8. Quirino Vincentin, conhecido como Leli, 93 anos, aposentado, morador do Riacho Grande 9. Solange Vincentin, 63 anos, filha de Leli, aposentada, moradora do Riacho Grande.

10. Alexandre Delijaicov, arquiteto e urbanista, professor da FAU-USP, frequentador da represa na infância.

11. Carlos Vieira, 55 anos, dono de quiosque na Prainha do Riacho e presidente da associação de comerciantes.

12. Vera e Julio, frequentadores da Prainha do Riacho.

13. Guibson, frequentador da Prainha do Riacho

14. Andrea e Luiz, frequentadores da Prainha do Riacho.

15. Tatieine, frequentadora da Prainha do Riacho

16. Rodrigo e Bruno, frequentadores do Parque Linear Cantinho do Céu.

\section{Os técnicos}

1. Marcos Boldarini, arquiteto, dirige o escritório Boldarini Arquitetos Associados que desenvolveu o Projeto do Parque Linear Cantinho do Céu. 2. Melissa Matsunaga, mestre pela FAU-USP em 2015 com o mestrado "Cantinhos do Céu", fez parte da equipe de projeto no escritório de Boldarini Arquitetos Associados que desenvolveu o Projeto do Parque Linear Cantinho do Céu.

3. Elisabete França, arquiteta, foi secretaria da Habitação entre 2010-2012 e Habitação e entre 2005 e 2012 foi Superintendente de Habita- ção da Secretaria de Habitação da Cidade de São Paulo, período em que o projeto do Parque Linear Cantinho do Céu se desenvolveu.

4. Marco Aurélio Garcia, Arquiteto e coordenador do projeto de revitalização da Prainha do Riacho Grande no âmbito da Urbaniza Engenharia, vencedora da licitação.

5. Fernando Bonisio, Chefe da divisão de Turismo e Eventos do Município de São Bernardo do Campo, esteve na equipe que coordenou o projeto de revitalização da Prainha do Riacho Grande.

6. Amauri Pollachi, coordenador do programa mananciais entre 2007-2015, coordenador da Câmara Técnica do Comitê de Bacia Hidrográfica do Alto Tietê (CBH-AT).

7. Ricardo Toledo, Professor Titular da FAU-USP e Secretário de Estado Adjunto na Secretaria de Energia do Estado de São Paulo entre os anos 2015-2018. 


\section{1. Águas para que $(\mathrm{m})$ ?}

\section{Rio, represa, residência}

(...) nos fundamentos efetivos da riqueza paulistana há que destacaro complexo hidrológico-topográfico do Estado, o qual permitiu um notável aproveitamento hidrelétrico, suficientemente acessível e volumoso para os esforços de industrialização (...) se é que o chão e os climas paulistas forneceram as bases de uma notável atividade agrária (...), o clima e as águas dos planaltos paulistas estão garantindo o aproveitamento de um bom potencial energético indispensável para o desenvolvimento de uma civilização industrial, a despeito do sensivel processo de desindustrialização que vem acontecendo nos últimos anos na capital paulista (AB'SABER, 2004: 87-88)

O processo de retificação dos rios e a constituição das represas em São Paulo ficou a cargo da São Paulo Tramway, Light and Power Company (Light). Como concessionária monopolista, a empresa iniciou uma série de transformações no território paulistano, cujas implicações têm desdobramentos até os dias de hoje. Entre as primeiras mudanças introduzidas pela companhia com a concessão para a produção de energia elétrica foi a construção da represa Guarapiranga entre 1907-1910, cujas águas eram reguladas através do leito do Pinheiros e Tietê de forma a alterar a vazão da Usina Hidrelétrica de Santana do Parnaíba hoje conhecida como Edgar de Souza.

O segundo grande projeto de geração de energia se aproveitando dos recursos hídricos de São Paulo, a Usina de Cubatão, reunia elementos muito favoráveis à empresa, como discorre o engenheiro Edgard de Souza, superintendente geral da Light a partir de 1924:

Esse projeto reúne 4 condições favoráveis dentro do território paulista e de difícil consórcio: grande altura de queda, grande descarga, grande reserva de águas e grande proximidade aos centros de consumo. Além disso, certas condições locais também favorecem seu estabelecimento. Taléo fato de coincidir a localização e enorme zona inundada em terras um pouco impróprias à agricultura, quase desabitadas, embora próximas à Capital, e, portanto, de reduzido valor. Se se tratasse de zona agrícola, como as do interior do Estado, o custo de aquisição 


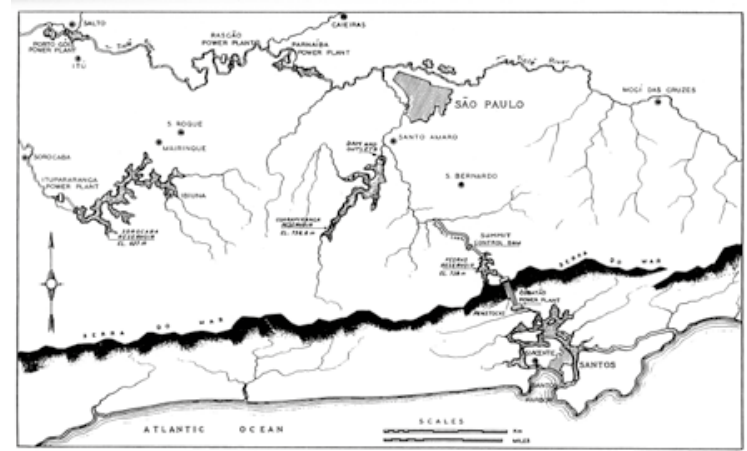

[1] A primeira etapa do projeto da Serra, 1927. Ackerman, 1953

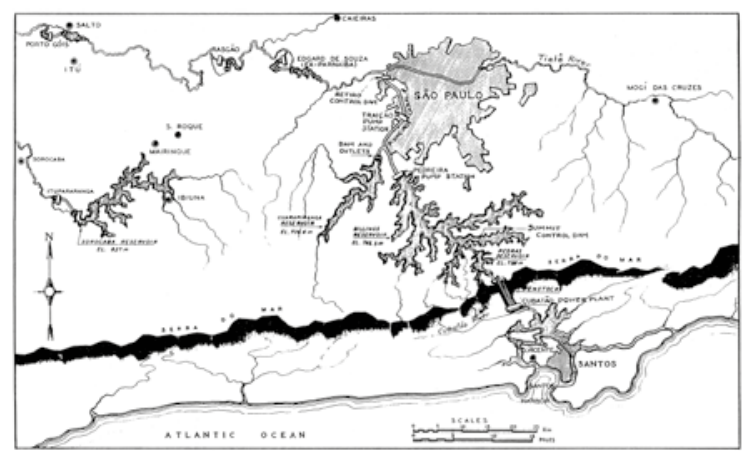

[2] A primeira etapa do projeto da Serra, 1927. Ackerman, 1953 poderia ser tão elevado que tornaria o plano inexequivel. Outra condição extremamente favorável é a do regime pluviométrico, porquanto os ventos do atlântico, carregados de umidade, produzem abundante precipitação nas cumeadas da Serra e no planalto adjacente em quantidade raramente excedida em qualquer outra região, chegando às vezes a precipitação ultrapassar 6 metros (SOUZA apud FILARDO JR, 1998: p.59).

O projeto fora idealizado com a ligação dos tributários do Tietê ao Rio Grande, mas revelou-se mais econômico para a empresa aproveitar as águas do Tietê à jusante com o aumento da capacidade do Rio das Pedras, de vertente marítima. Isso implicava grandes transformações no território paulista, desde a retificação e reversão de seus principais rios como o aumento, em relação ao primeiro projeto, da superfície alagada. A empresa sequer respeitou as cotas de alagamento estabelecidas no segundo projeto aprovado, que previa a lâmina d'água na cota 738. O projeto executado elevou a lâmina à cota a 745 , gerando a necessidade de barrar outros rios de vertente marítima. A empresa ainda teve a liberdade de desenvolver a execução progressivamente, pois podia estabelecer prazos de conclusão em função da flutuação de demanda, direito garantido pelos termos da concessão. Dessa maneira o sistema foi aumentando de capacidade ao longo dos anos, com um boom na produção de energia no final da década de 40, terminadas as obras de reversão do Tietê e Pinheiros.

Os desmandos da "Light" são relatados por SEABRA (1987) para quem não existia legislações de regulação das concessões cedidas à Light, o que tornava a regulação de suas atividades muito difícil para os órgãos públicos. Assim, os serviços empreendidos obedeciam à lógica e racionalidade da empresa, em um confronto desigual com os interesses públicos. Outro subproduto dessa atuação da companhia nas várzeas do Pinheiros e Tietê foi a produção de um imenso estoque de terras urbanas, que se tornaram propriedade da empresa através da obra de saneamento e retificação. Essas terras foram revendidas em hasta pública, ocasião em que a Light auferiu ganhos em dobro: cobrava na venda dos terrenos e na tarifa de energia o valor do investimento realizado. A empresa ainda acumulava 


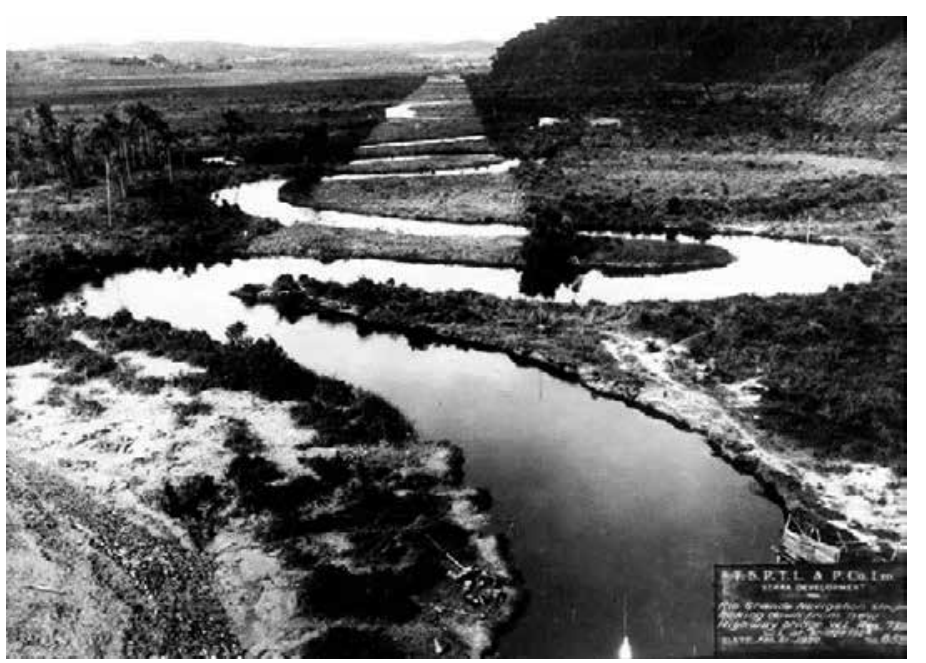

[3] Retificação Rio Pinheiros Acervo Fundação

Energia e Saneamento um patrimônio imobiliário para constituir reserva de valor nas operações de implantação de linhas de bonde e iluminação pública (PASCHES, 1995).

No tocante ao manejo dos recursos hídricos paulistanos, a Light desempenhou um significativo papel na inserção de rios e várzeas na dinâmica urbana. Com o crescimento da cidade, ambos foram ganhando outro significado. De lugar de atividades extrativistas para a população ribeirinha que vivia o ritmo natural do rio, passando pelos barqueiros que extraiam areia nas margens e várzeas, passou para o lugar da tecnologia de produção hidrelétrica. Esse potencial, como sugere AB'SABER (2004) na epígrafe, foi fundamental para a constituição da cidade capitalista industrial.

Essa transformação do significado dos rios foi progressiva. As lavras nas margens do Pinheiros foram diminuindo com o estabelecimento do monopólio da Light, que interferia na navegabilidade do rio abrindo e fechando as comportas da Guarapiranga conforme os interesses da empresa de produção de energia, prejudicando muitas vezes as atividades dos barqueiros. A diminuição das operações de lavra por particulares, permitiu, por algum período, que a Light assumisse essa atividade em condições de monopólio.

No Tietê, essa atividade foi tornando-se empresarial, com a introdução das dragas e empresas grandes na atividade. Cessou pouco tempo depois da fundação da Nitro química de São Miguel em $1935^{20}$, que, associada a outras atividades industriais próximas ao Tietê poluíram suas águas e contaminaram as lavras.

Entre os anos de 1925 e 1947 a Light conseguiu a concessão para executar todo tipo de obra que aumentava a capacidade de geração de energia na usina de Cubatão. O interesse da empresa nesse momento concentrava-se na atividade de geração de energia.

Assim a análise da transformação progressiva do significado dos rios por um conjunto de intervenções feitas neste período até a retificação do

20. A empresa foi fundada em 14 de agosto de 1935 como parte dos empreendimentos de José Ermírio de Moraes. A escolha do terreno próximo ao rio se deu pela necessidade de contar com abundante abastecimento de água para a fabricação e comércio de produtos químicos e têxteis. O primeira unidade a funcionar na fábrica foi de ácido sulfúrico, em 1937 Ver <http://www.saomiguelpaulista-sp. com/2013/09/fabrica-nitro-quimica-em-sao-miguel.html>, acesso em 20 dezembro de 2018. 
Pinheiros na década de 40 parece poder indicar como a empresa redefiniu o papel dos rios e massas d'água em função de novos imperativos econômicos, destituindo antigas vocações e funções culturais como a do lazer e da recreação.

A constituição da represa Billings está associada a um momento da história de São Paulo quando os rios se tornaram canais e represas para geração de energia. A Billings é, a princípio, o reservatório que transfere o volume das águas do Pinheiros para o Rio das Pedras na beira da Serra do Mar. Evidentemente, dada sua extensão e relação com a produção do espaço da cidade de São Paulo, novos usos e destinações aparecem ao longo da história e que particularmente interessa a dissertação investigar como surgem e coexistem, ou são negligenciados e discriminados.

A instância econômica tem tido papel fundamental na determinação espacial da represa, porém, outros determinantes como a cultura, a ideologia e o suporte físico, aspectos fundamentais da paisagem, são fatores igualmente determinantes. Parte-se do pressuposto que está se analisando uma paisagem em uma metrópole do terceiro mundo, cronicamente carente de infraestrutura, com predominância de sub habitações e grande deterioração do meio físico e do espaço antropizado ${ }^{21}$. Sabendo-se desse entendimento preliminar, é preciso buscar um enfoque próprio para a represa que possa considerar em sua dimensão questões de percepção em que a paisagem se apresenta como produto dinâmico entre processos sociais e processos naturais.

Os $100 \mathrm{~km}^{2}$ alagados da Billings abrangem, em sua área de drenagem, os municípios de Rio Grande da Serra, Ribeirão Pires, Diadema, Santo André, São Bernardo do Campo e São Paulo.

21. QUEIROGA (1994)
As tentativas de ocupação da região são anteriores a criação da represa e remontam às primeiras iniciativas do Brasil de incentivar a imigração europeia. Entre os anos 1827 e 1828 chegaram a Santos os primeiros grupos de colonos alemães, dentre os quais destacaram-se uma centena deles que ocuparam a região da cratera de Colônia e vizinhanças.

No período entre o final do século XIX até a anexação de Santo Amaro a São Paulo em 1935, o município vizinho teve uma dinâmica econômica considerável fornecendo matéria prima e mão de obra para a Capital. Esta condição foi favorecida pela acessibilidade da estrada de Ferro de Trens e Carris construída em 1886 e posteriormente sua substituição pelo bonde da Light em 1900. A linha de bonde, por sua vez, fez surgir diversos bairros em seu entorno.

A construção da represa no rio Guarapiranga em 1907 trouxe nova dinâmica à região. Além de sua função original serviu de espaço de lazer para os paulistanos que ali construíram chácaras de recreio, clubes e etc. Posteriormente, em 1928 a construção do eixo norte-sul, Av. Washington Luíz, em 1928, interligando a capital às áreas das represas, possibilitou a construção de residências de alto padrão e balneários em suas margens.

O decreto estadual 6.983/1935, que anexou Santo Amaro ao município de São Paulo, considerava a hipótese de tornar a região um pólo de lazer e indústria. A grande acessibilidade (por bonde, trem e avenidas marginais e Washington Luiz), a proximidade com as redes de transmissão da Usina Henry Borden e o potencial paisagístico das represas eram os fatores considerados (BERARDI,1969)

Em 1957 é concluído o ramal ferroviário de cargas e passageiros da antiga Estrada de Ferro Sorocabana, então FEPASA(Ferrovia Paulista S/A), que interligava a linha Júlio Prestes-Mairinque com 

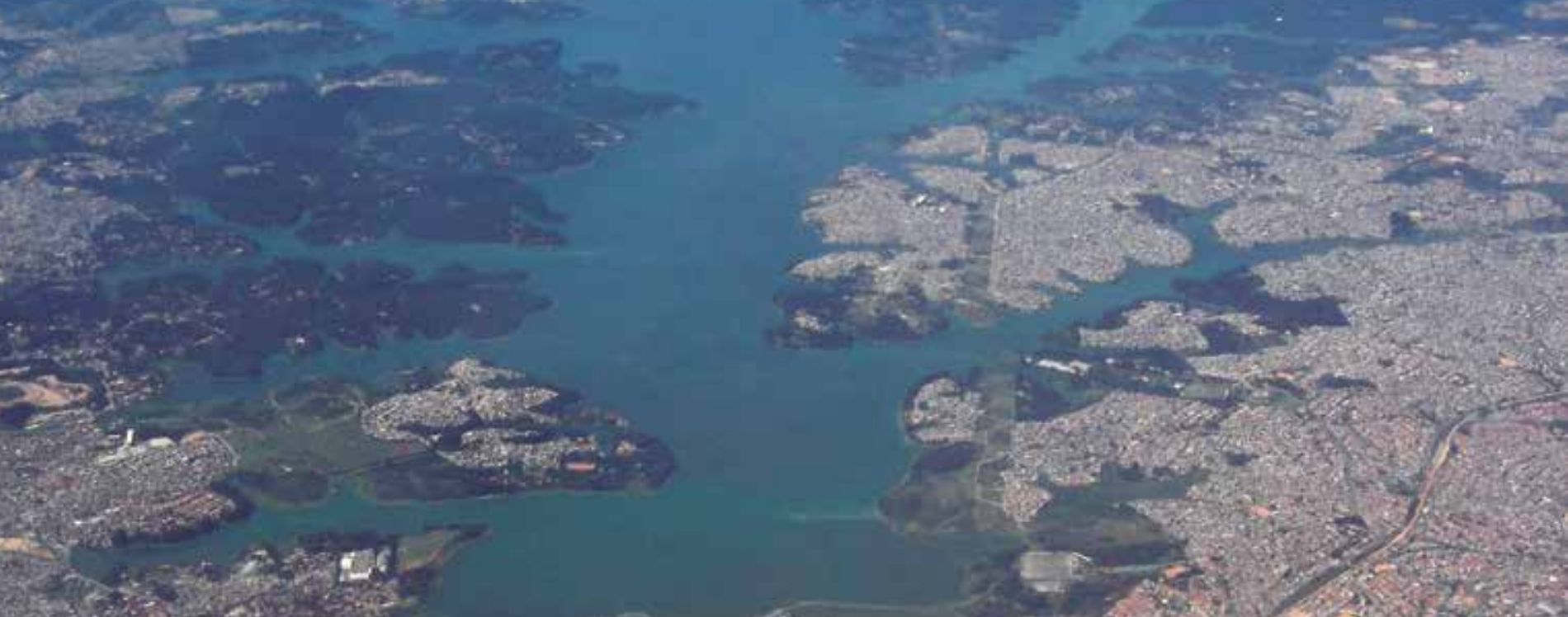

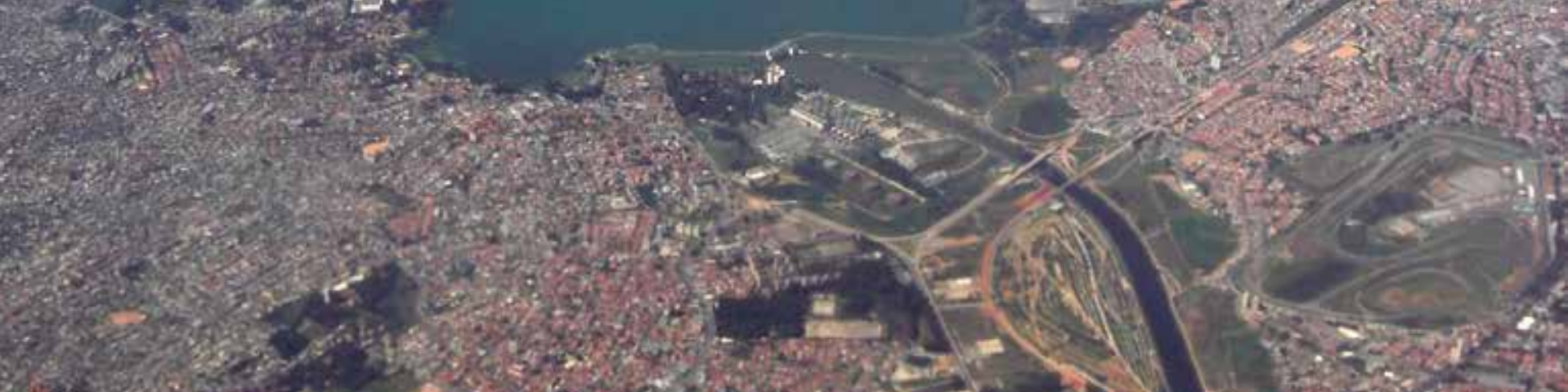

6.

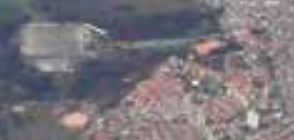

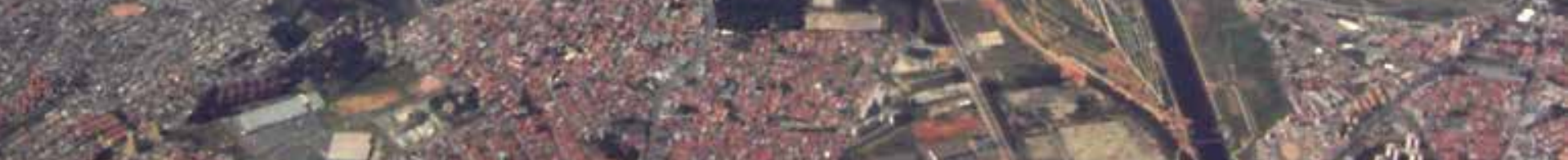

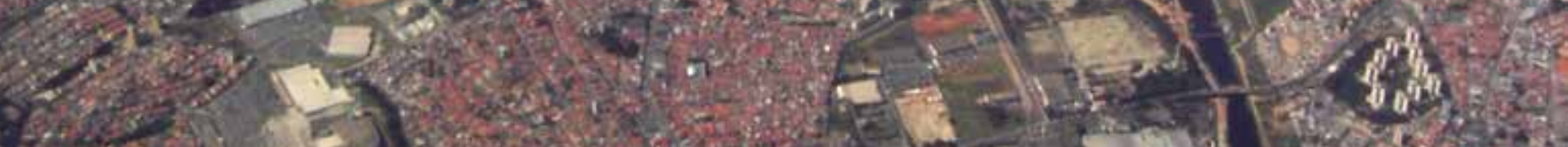

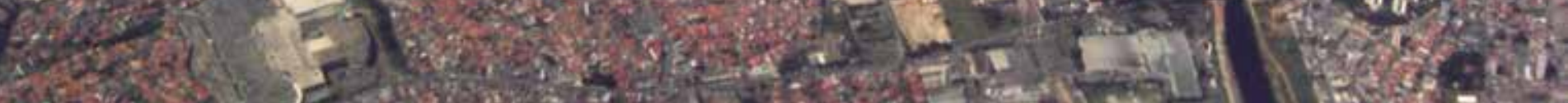
W.

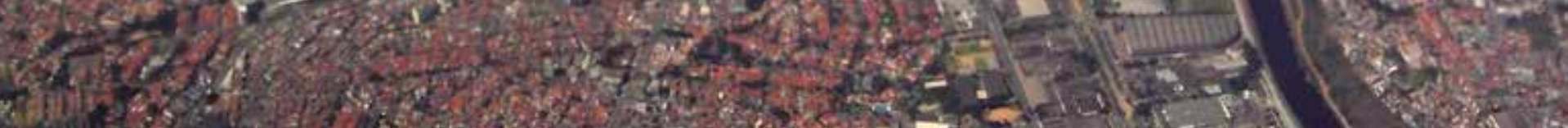

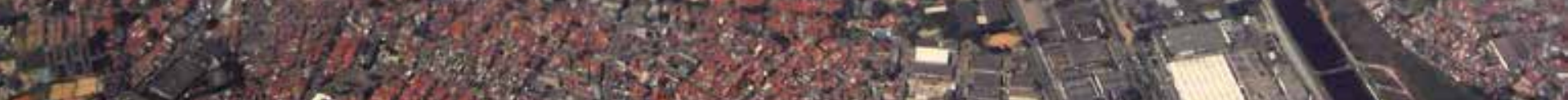

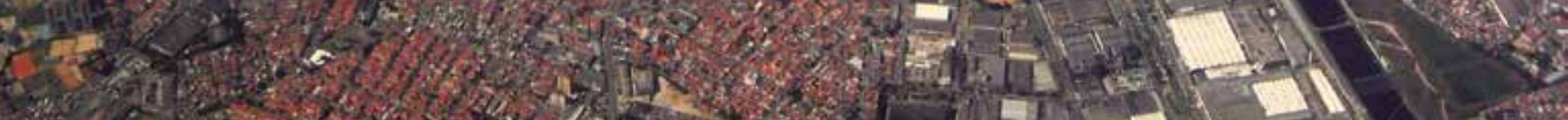

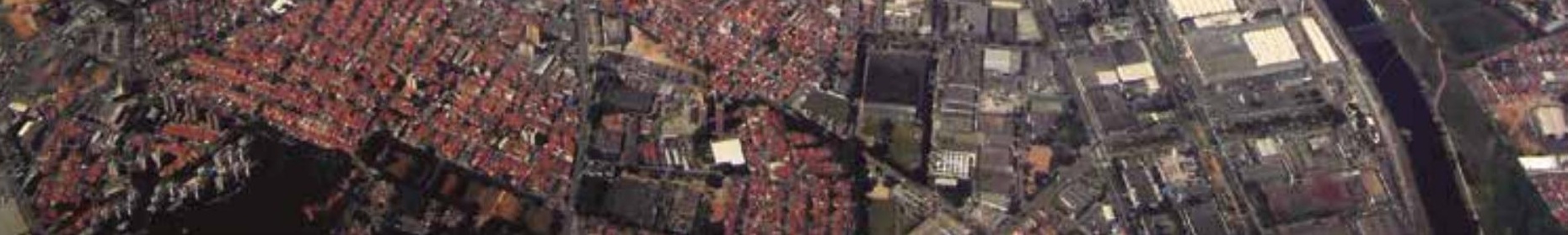

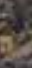


[5] Sobrevôo Billings,

2007 Andre Bonacin

a Santos-Mairinque, através das várzeas dos rios chegando a Interlagos, Grajaú, Itaim, Colônia Paulista e Barragem, entrando portanto na região dos mananciais pelas crista de divisão das bacias da represa Billings e Guarapiranga. Atualmente esse ramal da CPTM (Companhia Paulista de Trens Metropolitanos) opera até a estação terminal Grajaú.

Com a intensificação da industrialização e aumento no parque industrial de Santo Amaro, houve um incremento na demanda por trabalhadores, atendida pelos fluxos de mão de obra de outras partes da cidade e do país. Nesse período já se ensaiava o atendimento dessa demanda por moradia através dos loteamentos periféricos, solução que será amplamente utilizada nesta região, substituindo as roças rudimentares de caipiras alemães. Lotear suas propriedades foi a opção tomada pelos proprietários de terra frente ao aumento de impostos territoriais com a mudança de estatuto de suas propriedades, que progressivamente se tornaram urbanas.

"até os anos trinta, o problema da localização da mão-de-obra necessária para a indústria era em " grande parte resolvido pelas próprias empresas, através de vilas operárias - geralmente contíguas às fábricas - cujas casas eram vendidas ou alugadas a baixos preços aos trabalhadores: era o que ocorria em bairros como o Brás, Mooca, Belém e outros. A intensificação dos deslocamentos populacionais de origem rural, entretanto, permitindo a formação de um excedente de força de trabalho, tornou desnecessária a fixação do empregado na fábrica. Por outro lado, aumentou a pressão sobre a oferta de habitações populares e os terrenos, tanto fabris como residenciais, começaram a valorizar-se. Estes e outros fatores empurraram a massa trabalhadora para os bairros da perifeira de São Paulo e para os municipios circunvizinhos (...) MAGNANI (1982) p.7

O surgimento de bairros periféricos na região iniciou-se pela Cidade Adhemar, Campo Limpo e Jardim São Luiz. Processo semelhante acontecia nos outros municípios vizinhos da Região Metropolitana de São Paulo (RMSP), com surgimento de loteamentos periféricos nos municípios do ABC paulista. Entre os anos 70 e 80 houve um expressivo crescimento urbano nesta porção da metrópole com o aumento de loteamentos não compatíveis com a 
legislação para mananciais.

O ABC teve como impulso de crescimento urbano a presença do binômio ferrovia-terrenos grandes, unidos facilmente ao porto de Santos, dado que aquela região dependia de peças provindas do porto para o abastecimento industrial. A continuação desse processo favoreceu o crescimento denominado por Langenbuch (1971) de sub urbanização residencial, processo que será dinamizado com a construção de autoestradas, e o desenvolvimento do equipamento energético e formação de reservas de mão de obra.

Neste contexto e com a possibilidade de orientação das represas para uso exclusivo de abastecimento público de água, elaborou-se um documento, a Lei de Proteção aos Mananciais, que visava o controle de uso e ocupação do solo, estabelecendo parâmetros e usos permitidos. Contudo, pode-se observar que este documento não especificava as maneiras concretas de realização dos mesmos.

As represas passaram a ser consideradas como espaços de preservação dos recursos hídricos à medida que se consolidava a promulgação das Leis estaduais 898/75 e 1.172/76, de Proteção aos Mananciais da Região Metropolitana de São Paulo. A promulgação da lei, no entanto, não reverteu a situação de crescimento urbano nos mananciais e contraditoriamente teve um papel importante na desvalorização dos terrenos onde a lei incidia, o que ativou um mercado de terras clandestino que através de loteamentos ilegais manteve a direção anterior de ocupação pouco planejada na região.

Embora Langenbuch refira-se a um panorama do início da década de 70, parece antever o processo que teria continuidade nas próximas décadas:

Ainda hoje são terras que pertencem ao grupo do cinturão urbano intercalar, áreas que não são rurais, ou deixaram de ser, mas onde nota-se algumas chá- caras de produção agrícola, chácaras recreativas frequentemente de cunho residencial e aspecto deteriorado (...) As hortas comerciais, em geral, se implantam ai em terrenos arrendados, enquanto as chácaras recreativas - de modo geral - são conservadas até o momento em que boa oportunidade especulativa interesse seus proprietários pelo respectivo loteamento. Grandes extensões de terra aguardam tal oportunidade sem nenhuma utilização presente: glebas ermas são comuns no 'cinturão de urbanização intercalar' LANGENBUCH, (1971), p.298

Um dos bairros que parece melhor representar a dinâmica apontada por Langenbuch é a Capela do Socorro. O desenvolvimento industrial de Santo Amaro influiu consideravelmente na região, que teve rapidamente suas grandes áreas rurais e chácaras transformadas em loteamentos urbanos, com produção de terrenos a baixo custo que passaram a abrigar uma população de baixa renda. Uma boa parte de seus terrenos próximos à barragem de Pedreira já havia sido ocupada pela população mais pobre em razão da desvalorização que a operação de bombeamento das águas do Rio Pinheiros gerou, tornando o local um espaço malcheiroso e degradado.

O crescimento populacional na região é um importante indicativo dessa transformação. O que hoje conhecemos como a unidade territorial da Subprefeitura da Capela do Socorro, contava apenas 30.000 habitantes em 1960 numa extensão territorial de $134 \mathrm{~km}^{2}$. Teve um crescimento de 768\% em 20 anos chegando a 261.230 habitantes em 1980, e novo salto de $130 \%$ até 2010 quando se contabilizou pelo censo um total de 684757 habitantes ${ }^{22}$. Em razão

22. Fonte: PMSP em www.prefeitura.sp.gov.br acesso em julho de 2016 


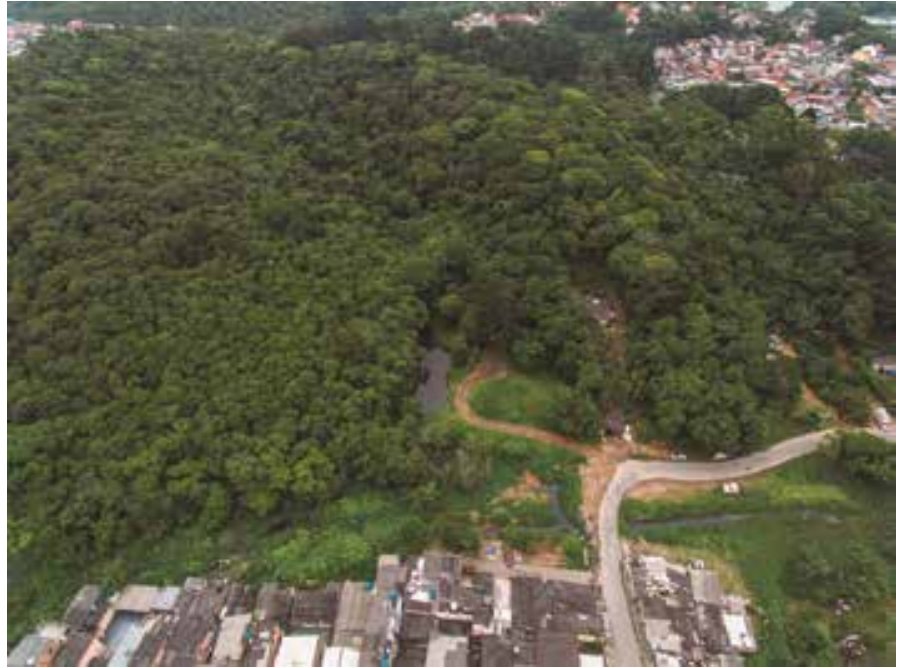

[6] Vila Pelé em São Bernardo do Campo Vôo Drone 2018

Carolina Gimenez e Michel Gubeissi da grande extensão territorial, a densidade é ainda de apenas 44,33hab/ha. Em termos comparativos, trata-se de uma densidade baixa, se considerarmos as Subprefeituras da Sé (164,54 hab./ha) ou Freguesia/Brasilândia (129,28 hab./ha) para tomar de exemplo regiões centrais e periféricas do município. No entanto, cerca de $90 \%$ de seu território está inserido em área de proteção aos mananciais com restrições normativas à ocupação. Houve intenso adensamento em áreas inclusas ou não em proteção de mananciais bem como ocupações precárias em área de restrição a ocupação. Uma parte considerável dessa demanda foi atendida com o auto provimento de moradia, exceção feita aos loteamentos destinados a outras faixas de renda implantados principalmente na margem direita da Guarapiranga.

A porção das margens a Sul do rodoanel ainda guarda as características descritas por Langenbuch para o "cinturão urbano intercalar", com exceção de alguns lugares de entroncamento com eixos viários, notadamente a via Anchieta, onde havia o antigo porto fluvial do Riacho Grande e que atualmente se desenvolvem atividades de lazer relacionadas à represa, contando com pouca infraestrutura. São subúrbios residenciais, desvinculados funcionalmente da Billings, que se alternam com chácaras recreativas, lojas de pesca, pesqueiros e clubes de recreio fechados. Nas margens da represa, banhistas, pescadores, lixo e esgoto.

Essa condição de suspensão ou indefinição da função de grandes porções desse território sinaliza a importância de investigação do campo de interesses e conflitos a respeito dos usos e destinos das águas da represa Billings. Por exemplo, a função lazer tal como é descrita lei 1172/76 imprime uma perspectiva de lazer que se traduz na restrição do uso a poucas pessoas o que, no entanto, precisa ser analisada e repensada sob a ótica do uso coletivo em escala metropolitana em que a represa se insere.

Em 2009 houve uma nova tentativa de regulação do uso do solo no entorno da represa através da promulgação da Lei n 13.579, que definiu a Área de Proteção e Recuperação do Mananciais da Bacia Hidrográfica do Reservatório Billings denominada APRM-B. A bacia foi dividida em 5 grandes compartimentos ambientais para os quais se definiu o uso e ocupação do solo, as estratégias de compensação ambiental para loteamentos já existentes e prerrogati- 


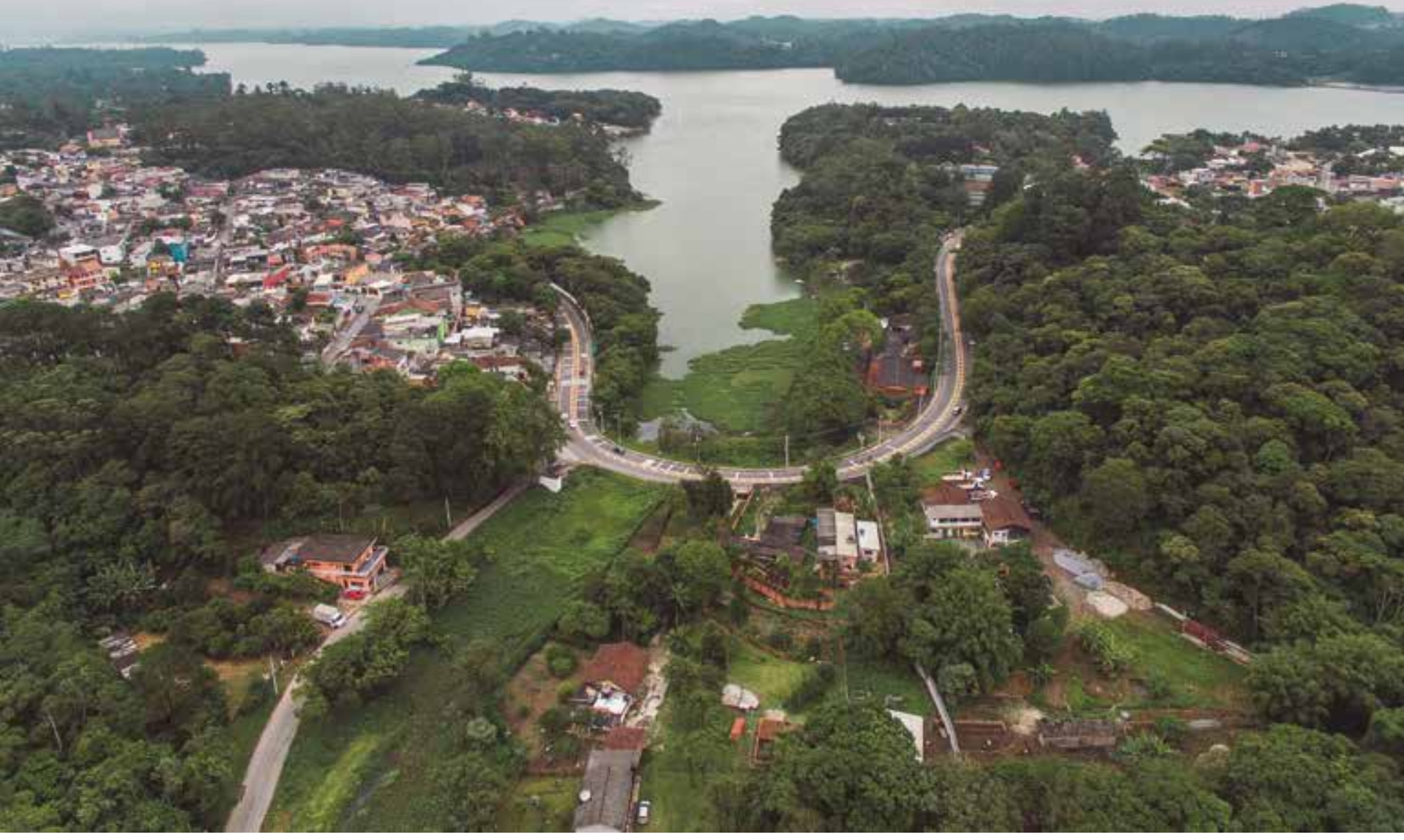

[7] Micro bacia Vila Pelé em

São Bernardo do Campo

Vôo Drone 2018

Carolina Gimenez e Michel Gubeissi 

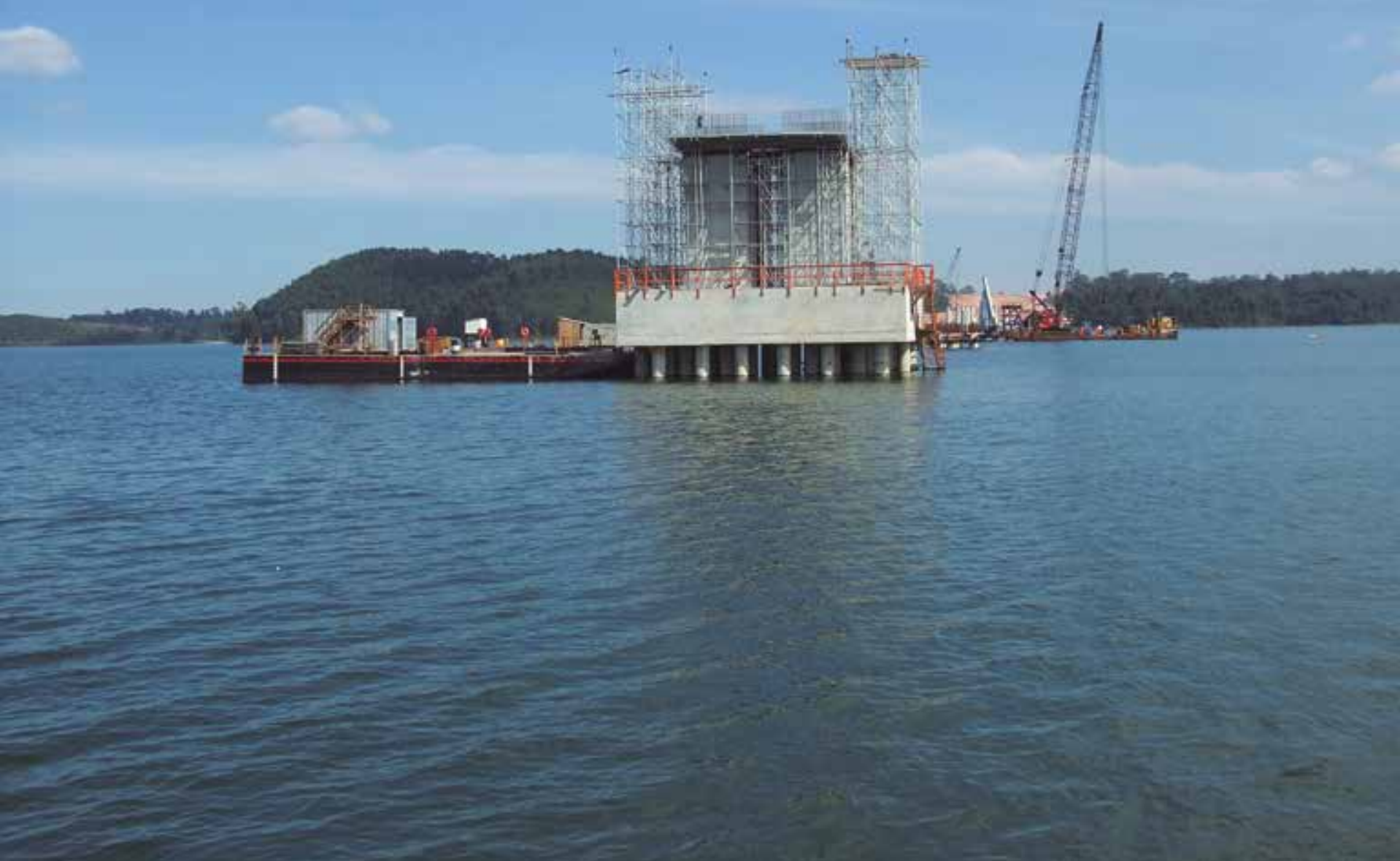

[8] Construção rodoanel

Carolina Gimenez, 2008 

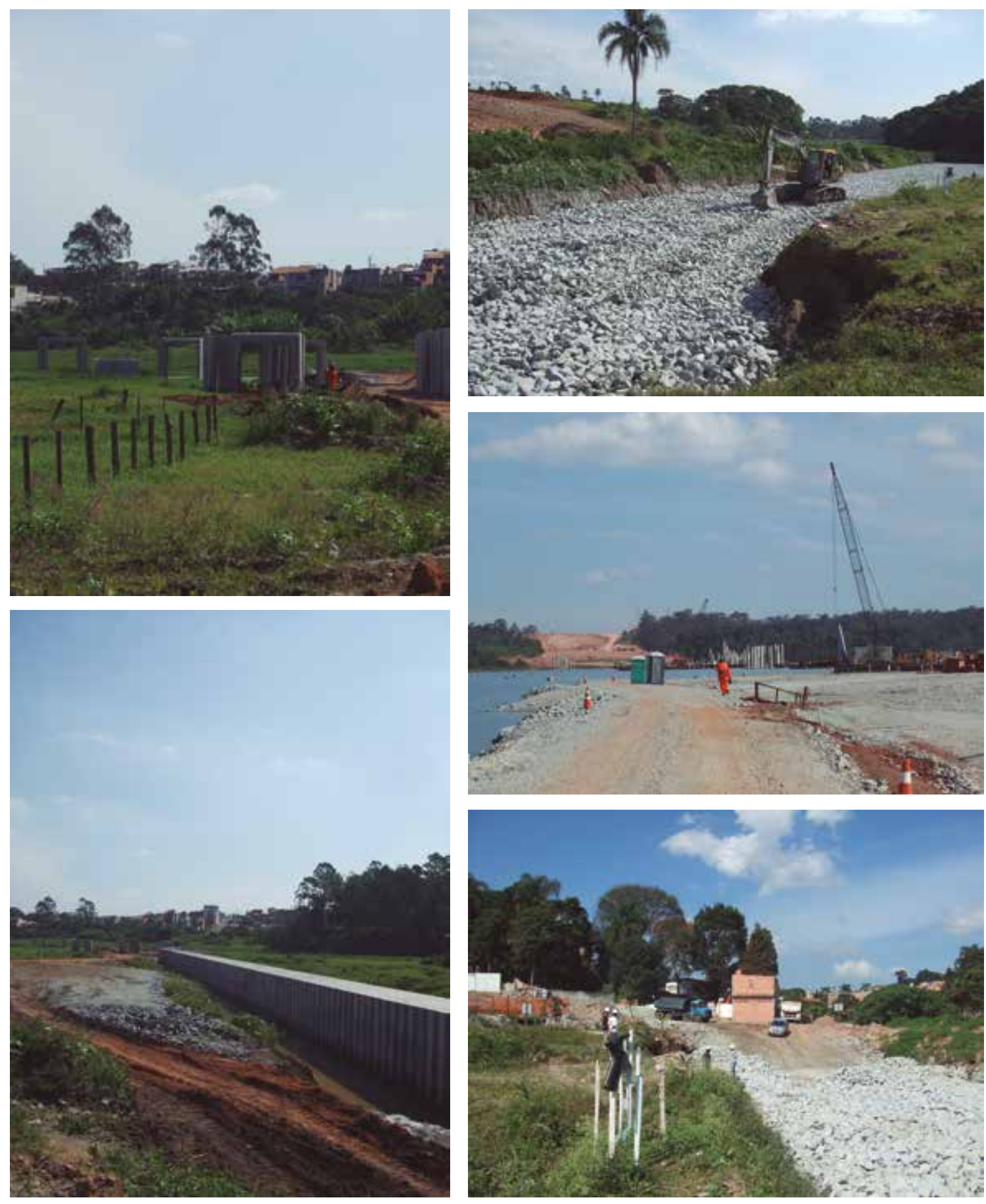

[9 a 13] Construção rodoanel

Carolina Gimenez, 2008 
CRISE DA ÁGUA

\section{Esperança contra crise da água em SP, Billings é caixa-preta de poluição}

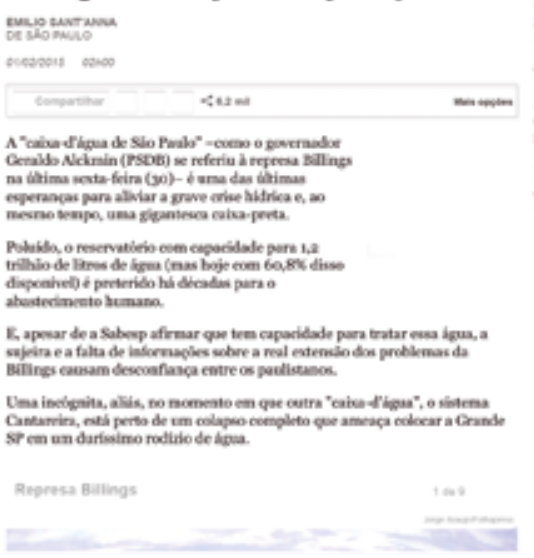

[14] Esperança contra crise da água em SP, Billings é caixa-preta de poluição

Folha de S.Paulo

Cotidiano - 01.02.2015

\section{Setecidades}

Billings é caixa-d'água de São Paulo, afirma presidente da Sabesp

leia também

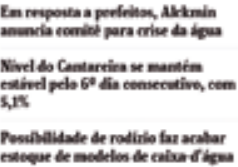

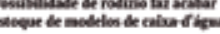

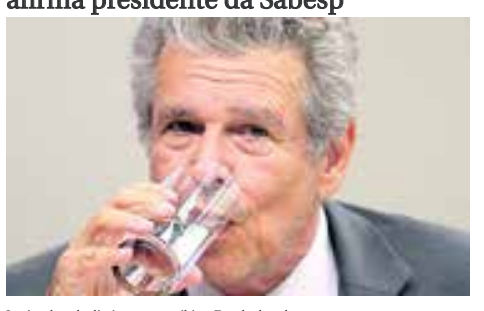

ustiça derruba liminar que proibia o Estado de cobr

Yara Ferraz
Do Diario do Grande ABC
15/001/2015|07:00

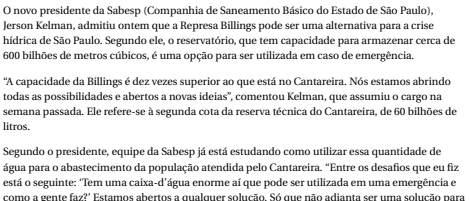

[15] Billings é caixa-d'água de São Paulo, afirma presidente da Sabesp Diário do Grande ABC, 15.01.2015

vas dos municípios no tocante aos investimentos em infraestrutura de saneamento. A lei buscou priorizar a permanência das populações já residentes na bacia, de certa forma relativizando o princípio da intocabilidade da APP, mas sem descartar a necessidade de adequações nos loteamentos com vistas a garantir a qualidade da água da represa.

Em capítulos mais recentes de sua história, durante a crise hídrica de 2015, o papel da represa como grande manancial capaz de solucionar a escassez de água potável em São Paulo retomou as manchetes de jornal. Naquele momento a represa foi apontada como "a grande caixa d'água" de São Paulo pelo então recém empossado presidente da Sabesp Jerson Kelman e na sequência pelo próprio Governador Geraldo Alckmin.

A frase de efeito, em coro com o presidente da Sabesp, "caiu mal", uma vez que o próprio estado, por meio de sua concessionária, continua a ser responsável por parte significativa do lançamento do esgoto in natura na represa, vez que distribui água potável sem cuidar do esgotamento sanitário em sua concepção integral. Apesar de todo esforço do governador em tranquilizar a população sobre a disponibilidade de água para a capital, a solução de ampliar o uso da represa para abastecimento foi e continua sendo vista com desconfiança.

A Billings é de certa forma um símbolo do fracasso do modelo de gestão dos recursos hídricos. De 2015 para cá, não houve avanço significativo na redução das cargas poluidoras em seu entorno ${ }^{23}$ - O monitoramento da água da represa feito pela Sabesp mesmo com algumas lacunas ${ }^{24}$ demons-

23. Dados presentes no site da sabesp http://site.sabesp.com.br/site/ interna/Default.aspx?secaold=43. Acesso em 18.01.2017

24. Os dados a respeito da demanda biológica de oxigênio 
tra que a demanda biológica de oxigênio (DBO), principal medidor para poluição continua em alta desde 2010, ano seguinte a promulgação da lei que definiu a APRM-B, e não apresentou diminuição até as últimas medições de 2017.

Neste cenário complexo e imbricado as mudanças devem envolver diversos atores e frentes. As possiveis soluções passam por um pacto na sociedade entre as organizações sociais e ambientais, Estado e setor privado.

\section{Planos X ações}

A bacia hidrográfica da Billings faz parte da formação geográfica denominada Planalto Paulista. A topografia regular desta formação é frequentemente sulcada por rios configurando vales de vertente continental. Na estrutura hídrica metropolitana, está inserida no sistema Alto Tietê.

Da perspectiva administrativa e gerencial, está inserida na Unidade de Gerenciamento de Recursos Hídricos do Alto Tietê - denominada UGRHI 06. Trata-se da bacia mais intensamente urbanizada do país ${ }^{25}$.

Há praticamente uma correspondência entre a delimitação física da bacia e a Região Metropolitana de São Paulo (ver figura 16), o que impõe enormes desafios entre as práticas de gestão urbana e a gestão dos mananciais nela inseridos

(DBO) aparecem de forma intermitente nos laudos da Sabesp. Pegando o mês de referência dezembro, podemos encontrar dados referentes aos anos de 2010 e 2011, pulando os anos de 2012, 2013 e 2014, retomando as mediçōes em 2015, 2016 e 2017. Para mais informaçōes consultar o site da Sabesp em: http://site.sabesp.com.br/site/interna/Default.aspx?secaold=43. É importante destacar no entanto que a responsabilidade pela medição é da Cetesb.

25. Segundo a Revisão do Plano da Bacia Hidrográfica do Alto Tietê disponivel em http://www.sigrh.sp.gov.br/public/uploads/documents/7111/pat_sumario_executivo.pdf acesso em 19.01.2018.
"Comparativamente a todas as UGRHIS (Unidade Gerencial de Recursos Hídricos) do Estado, a UGRHI-06 é a que dispõe de menor oferta de água per capita, com 130,68 m³/ano por habitante, devido à sua reduzida área geográfica e elevada concentração populacional. No curto prazo, cabe aos municipios conter a ampliação das áreas urbanizáveis e coibir invasões nos espaços ainda disponiveis, em particular nas áreas de mananciais" 26

O órgão responsável pelo gerenciamento da UGRHI-06 é o Comitê da Bacia Hidrográfica do Alto Tietê cuja criação ocorreu por lei estadual em 1991. Como parte dos trabalhos do Comitê, foi elaborado um Plano para a Bacia em 2002, com revisão em 2009. Os documentos apresentam um diagnóstico de toda a bacia e apontam para alguns encaminhamentos a serem adotados para a melhoria na qualidade e disponibilidade de água no sistema. Embora esteja presente a ideia de gestão integrada nos planos específicos para Bacia do Alto Tietê, defendendo a ideia de articulação entre gestão hídrica e políticas territoriais e ambientais, não se discute uma saída institucional para tal, vez que não se apresenta a forma dos municípios adotarem políticas de uso e ocupação do solo que estejam em acordo com as premissas do plano.

Alguns estudos ${ }^{27}$ sobre o papel do Comitê na gestão da Bacia do Alto Tietê bem como as formas como tem sido abordados os conflitos de uso dos recursos hídricos desta Bacia por diferentes agentes do Estado apontam que embora haja formalmente a instância de gestão integrada, ela não se traduz em ações efetivas, ou seja, a gestão metropolitana, fundamental para a qualidade satisfatória dos rios

26. Idem, ibidem.

27. Tais como ALVIM(2003), PENTEADO, ALMEIDA, and BENASS I (2017) entre outros. 


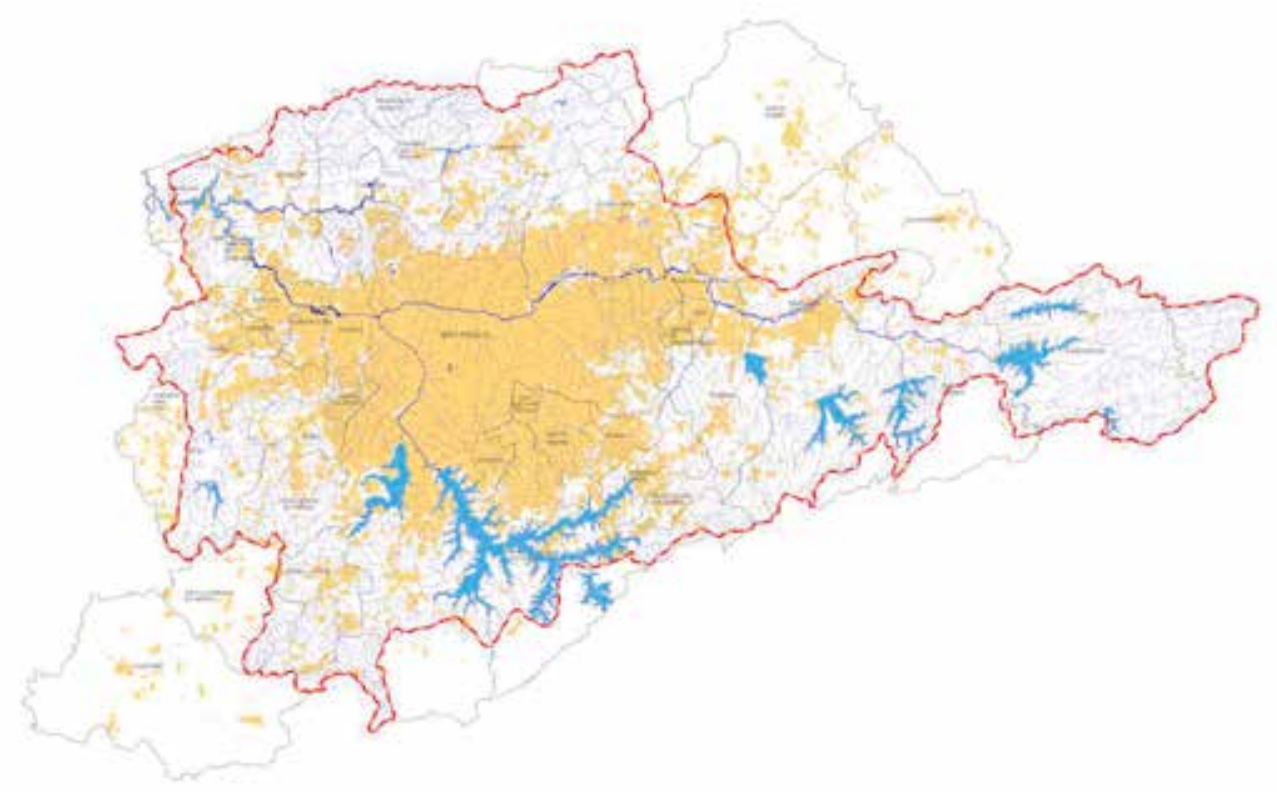

[16] Bacia do Alto Tietê:

pertinência na RMSP

Em vermelho,

delimitação da bacia

Fonte: SP PERH 2004

[17] Demanda / disponibilidade $(Q 7,10)$

Q 7,10 é vazão mínima média de

7 dias consecutivos e 10 anos

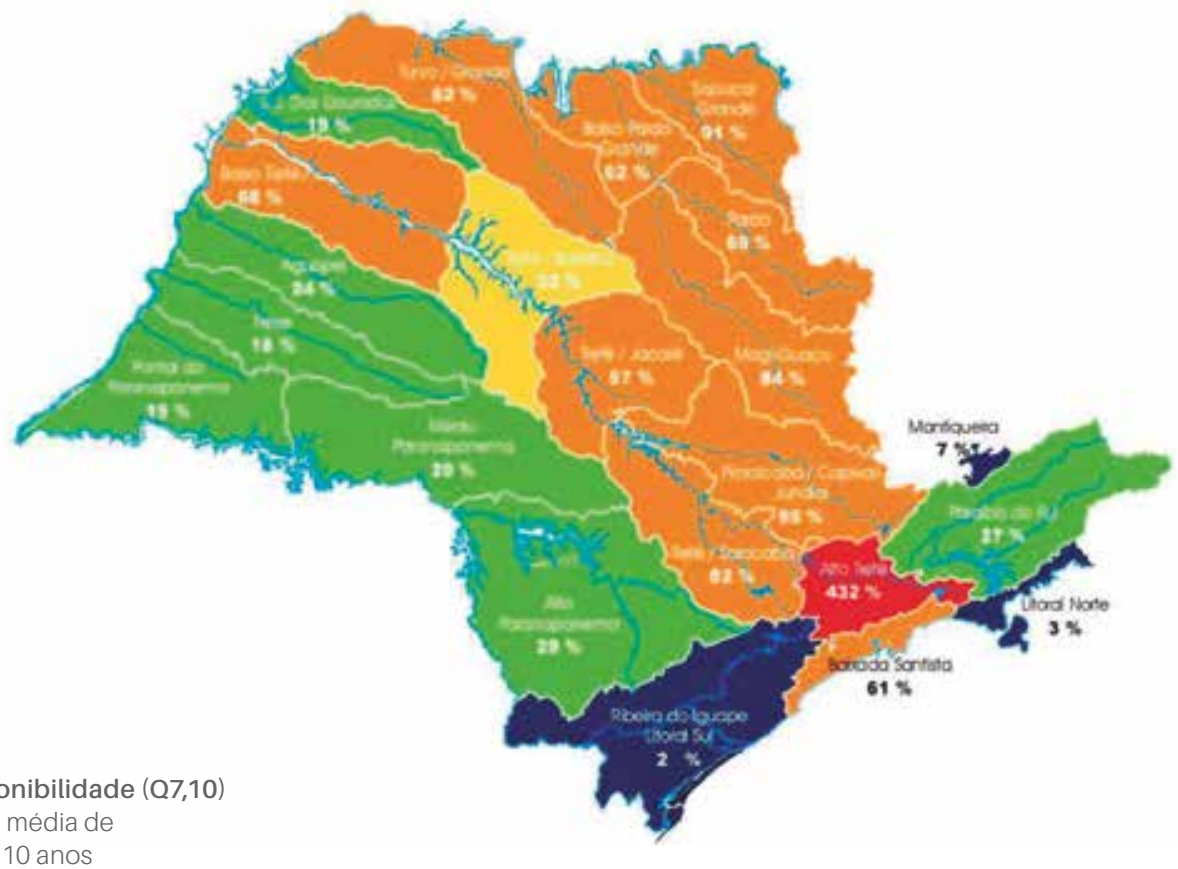

de período de retorno

Fonte: SP PERH 2004 
e represas da cabeceira do Tietê, continua sendo um horizonte distante a se atingir:

"Com a adoção da gestão descentralizada, muitas ações integradas têm sido propostas e consolidadas no Plano de Bacia; contudo, outros problemas têm emergido durante a implantação. Apesar de todos os benefícios assinalados pela adoção do Plano de Bacia, no caso do estado de São Paulo, o plano tem apenas um caráter indicativo - apresenta a melhor proposta do ponto de vista técnico, mas não pode ser imposto nem estabelecer prioridades às agências públicas e municipalidades" CAMPOS e FRACALANZA (2010) p.374

Em entrevista com um de seus membros, Amauri Pollachi, fica evidente que para além da dificuldade em tornar o Comitê um órgão deliberativo e não apenas consultivo, nos últimos anos houve um enorme esvaziamento. Embora haja reconhecimento dos avanços que poderiam ser trazidos por uma gestão integrada, a situação atual é de abandono da instância por parte de atores importantes do Comitê. Ao se referir a legislação ${ }^{28}$ Amauri comenta:

"Essa legislação foi muito bem vista na época por seruma espécie de arena de discussões regionais em que se falava a respeito da questão da água e uso do solo. Mas essa percepção foi se esvaziando ao longo do tempo e percebemos que são muito raros os Comitês em que existe uma participação intensa e presença efetiva, normalmente são aqueles Comitês em que existe escassez de água, e isso é visto como uma questão política relevante. No caso do Alto Tietê não se tem essa

28. Lei Estadual 7663/1991 que estabelece normas de orientação à Política Estadual de Recursos Hídricos bem como ao Sistema Integrado de Gerenciamento de Recursos Hídricos. percepção porque se importa água das bacias vizinhas, embora nós tenhamos passado por uma crise extremamente grave entre 2013 e 2016, não houve uma articulação política principalmente na esfera municipal no sentido de perceber isso como uma prioridade a ser tratada na região. A articulação política dentro da região metropolitana de São Paulo é sensivelmente desgastada, não tem algo que cria uma unidade como na região de Campinas e Piracicaba, em que a escassez de água é vista como um problema grave desde os anos 80. Não é assim aqui, a gente precisaria passar por outra crise talvez para se ter essa percepção (...)"

Em relação a participação no Comitê dos municípios de São Paulo e São Bernardo, casos estudados por essa dissertação:

"A partir de 2017 a atuação dos municipios tem
sido nula, estamos falando de dois municipios ab-
solutamente relevantes, São Bernardo sequer envia
representante para nós, São Paulo enviou algumas
vezes representantes absolutamente descolados
da realidade".

Ricardo Toledo, secretário adjunto de Minas e Energia no Governo Estadual entre os anos $2014 \mathrm{e}$ 2018, corrobora a tese de que embora tenha sido uma ideia inovadora, inspirada nos modelos europeus de gestão das águas, na prática não teve o resultado esperado ${ }^{29}$.

O Plano apresenta a situação em que a demanda hídrica nesta bacia supera sua disponibilidade natural e que esse fator impõe problemas crônicos de abastecimento de água. Para 2035 será necessário incluir $32 \mathrm{~m} 3 / \mathrm{s}$ no sistema considerando

29. Em entrevista no dia 21.01.2019. 
Demanda total (Urb+Ind+Irrig) da Macrometrópole, m3/s

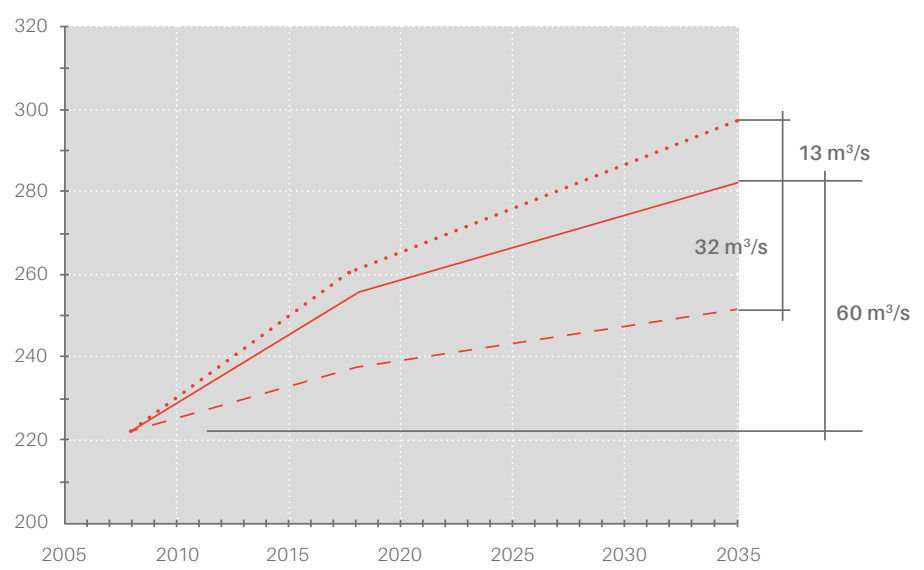

[18] Cenários

(tendencial, cresc. econômico, gestão da demanda)

Fonte: São Paulo, Estado, Departamento de Águas e Energia Elétrica - DAEE (2013) - Plano de Aproveitamento dos Recursos Hidricos da Macrometrópole Paulista www.daee.sp.gov.br/index.php?option=com_co ntent\&view=articleqid=1112:plano-diretorde-aproveitamento-dos-recursos-hidricospara-a-macrometropole-paulista Acesso em janeiro de 2019

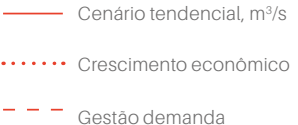

um cenário de gestão da demanda ${ }^{30}$ e de taxas de crescimento baixas, do contrário, será necessário um acréscimo de $73 \mathrm{~m}^{3} / \mathrm{s}$. Dito isto, a solução preconizada para expansão será através da importação de água de bacias vizinhas.

A represa Billings poderia aportar cerca de 1/3 dos recursos necessários, com uma contribuição de $10 \mathrm{~m}^{3} / \mathrm{s}^{31}$, porém não é contemplada para essa expansão. Esses números desconsideram eventuais recuperações de áreas assoreadas, que poderiam aumentar a vazão de retirada.

Por se tratar de região de cabeceira, há uma alternância grande entre situações de cheia e seca, algumas delas bastante severas como a crise de 2015 e de 1963 (ver figura 19).

Dessa maneira, os reservatórios dentro do sistema Alto Tietê são de extrema importância. Por outro lado, sabe-se que a configuração geográfica e territorial dentro da UGRHI-06 atingiu seu limite

30. Segundo Ricardo Toledo melhorias na rede, adoção de diferentes pressōes, trocas de válvulas, seriam as açōes tangiveis e mensuráveis para se chegar nesse volume. Entrevista a autora em 21.01.2019.

31. Idem. O entrevistado defende que esse volume seja considerado, diferentemente do consenso no setor. de armazenamento ${ }^{32}$, ou seja, seria um contrassenso desprezar a contribuição da Billings nessa equação, visto que é o maior reservatório dentro da Macrometrópole e permitiria reduzir a dependência do sistema Cantareira num horizonte mais próximo.

O paradigma da escassez poderia ser visto para além de determinismos geográficos ou resignação diante dos desafios de recuperação ambiental? Estratégias capazes de contribuir localizadamente para a qualidade das águas da Billings, e isto reproduzido em escala, poderiam expandir mais rapidamente a produção de água na represa, oferecendo alternativas às custosas obras de transposição de bacias, além dos conflitos regionais que tais transposições geram? Para além de questões sobre custos, existe ainda uma discussão ética sobre a priorização de investimentos em áreas socialmente vulneráveis cuja baixa taxa de infraestrutura sanitária impõe a milhares de habitantes condições de vida bastante precárias.

É então possível pensar uma forma de conservação dos recursos naturais que não se oponha ao desenvolvimento urbano? Até o

32. Ricardo Toledo, em entrevista no dia 21.01.2019. 


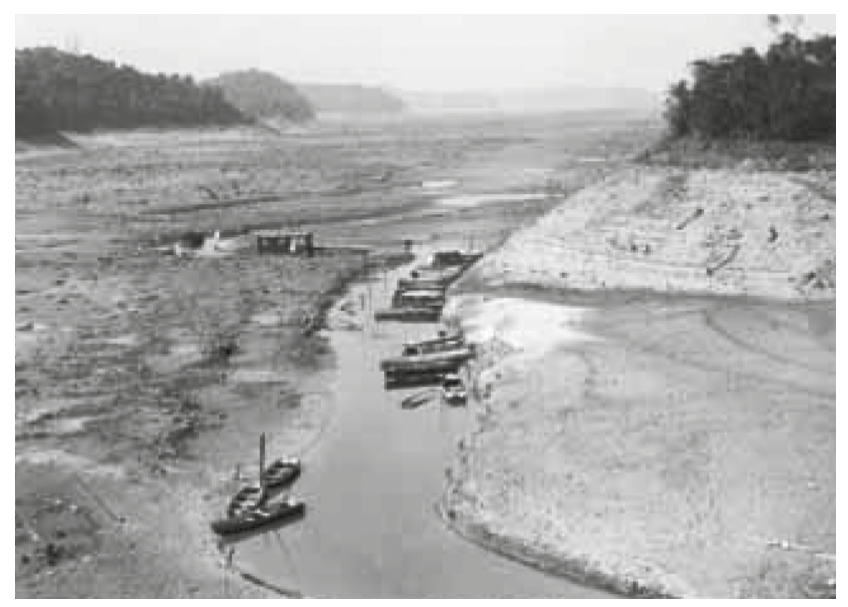

[19] A grande seca de 1963 fez com que a represa Billings secasse a tal ponto que praticamente se viu o Rio Grande em seu leito original, revelando alicerces das antigas casas da Vila do Riacho Grande que haviam sido cobertas por água Acervo Funcação de Saneamento e Energia. momento esse tem sido o grande desafio dos loteamentos próximos à Billings.

Da perspectiva do esgotamento sanitário, também a tradicional solução de interceptação e bombeamento dos efluentes para a uma grande Estação de Tratamento de Esgotos (ETE) poderia ser questionado, visto que em diversas situações o adensamento ocorreu em áreas de difícil acesso a coletores tronco e interceptadores. Assim, as soluções descentralizadas, com pequenas estações de tratamento de esgoto estão entre os novos paradigmas a serem estudados.

Ainda que seja necessário problematizar o uso da Billings como reservatório para produção de energia nas condições atuais de saneamento no município de São Paulo, cabe mencionar a importância do aporte energético que fornece nos horários de alta demanda. A usina de Henry Borden, considerada de alta produtividade ${ }^{33}$, é frequentemente ativada durante picos energéticos que atualmente se concentram próximos ao horário de almoço em razão da

33. Segundo Ricardo Toledo, a produtividade da água vertida pela Billings na Henry Borden é de $5,65 \mathrm{MW} / \mathrm{m}^{3} / \mathrm{s}$. É cerca de cinco vezes mais produtiva que Itaipu. expansão do uso de aparelhos de ar condicionado:

"Por determinação do Operador Nacional do Sistema (ONS - Sistema Integrado) a UHE (Usina elétrica acionada por energia hidráulica) Henry Borden despacha a plena carga nas situações de pico de demanda (diariamente se necessário), sem o que a segurança energética do Leste Paulista (inclusive RMSP) fica comprometida. Essa operação a plena carga por poucas horas faz com que nas demais horas o nível de ociosidade da hidrelétrica - que tem capacidade instalada de $890 \mathrm{MW}$ - fique maior, de maneira a se ater aos 127 MW médios de energia assegurada." ${ }^{134}$

Parece ser consenso, entre os diversos atores que disputam o uso das águas da represa, que a melhor forma de gestão de seus recursos é através de ações compartilhadas, porém ainda não se encontrou uma saída institucional e financeira para tal. Em artigo sobre os conflitos hídricos em dois

34. idem. 
[20] Estrutura hídrica metropolitana Fonte: O Plano Integrado de Aproveitamento e Controle dos Recursos Hídricos das Bacias do Alto Tietê, Piracicaba e Baixada Santista (HIDROPLAN) por Hiroaki Makibara

reservatórios que servem concomitantemente a abastecimento público e geração de energia, PENTEADO, ALMEIDA, e BENASSI (2017) afirmam:

"É fundamental conhecer os passivos ambientais presentes nos reservatórios hidrelétricos Billings e Barra Bonita quantificando-os e qualificando-os, e criar instrumentos econômicos para viabilizar ações compartilhadas entre atores envolvidos. Porque, isoladamente, os atuais mecanismos de recuperação desses reservatórios estão distantes de atingir resultados plenos dentro de aspectos socioambientais" p. 318

Entre os planos em que se articularam ações e atores interessados na recuperação dos mananciais de São Paulo o Programa Guarapiranga foi citado pelos técnicos aqui entrevistados ${ }^{35}$ como uma experiência pioneira na forma como se trataram as questões ambientais no município de São Paulo

35. Amauri, Ricardo e Elisabete. naquele período. Há uma extensa literatura ${ }^{36}$ sobre o Programa e seus desdobramentos com a extensão do mesmo para a bacia da Billings dentro do escopo do Programa Mananciais, no entanto dados atuais ${ }^{37}$ sobre assentamentos precários na bacia demonstram a dificuldade em se manter ações estruturadas e contínuas em relação ao uso e ocupação do solo na área de contribuição da represa.

36. FILLARDO (2005), FERRARA (2013, 2018), POLLI (2010) apenas para citar os consultados aqui.

37. Ver FERRARA (2018) p.419. 


\section{Riacho Grande}

\section{O percurso}

Inicia-se o percurso ${ }^{38}$ de carro partindo da Cidade Universitária $(0 \mathrm{Km})$ em direção a São Bernardo através da planície fluvial do Rio Pinheiros em direção à São Bernardo do Campo. Percorre-se a marginal Pinheiros até a ponte Ari Torres ( $5 \mathrm{Km}$ ), de onde se vê à direita a imponente elevatória de Traição e a subestação da Eletropaulo com suas linhas de alta tensão. Estando em cima da ponte, se avistam as inúmeras torres que compõe o skyline de prédios corporativos da Berrini e da Via Funchal. Alguns deles, com suas fachadas espelhadas, ofuscam quem passa de carro. Ao tocar o chão, na Avenida Bandeirantes, segue-se em 5 pistas assentadas em cima do córrego Traição tendo ao lado generosos canteiros que preservam os bairros do entorno.

Atravessando a planície fluvial do Pinheiros -

38. Os dois percursos tiveram sua origem na Cidade Universitária e destinos Riacho Grande e Cantinho do Céu. Foram realizados de carro. Elaborei a descrição através de memórias como motorista e passageira e posteriormente adicionei informaçōes do Gegran e Google Maps para a indicaçāo correta de cotas e distâncias. Defini o marco zero de quilometragem na Cidade Universitária $(0 \mathrm{Km})$ e na sequência indico, em alguns marcos, a distância percorrida em quilometros desde a origem. Em ambos os percuros a média de tempo entre origem e destino foi de uma hora, a não ser em dias de chuva ou horário de pico. entre as cotas 724 e 734- por bairros de alto padrão, chega-se ao principal eixo norte-sul da cidade, que coincide com o grande talude quadriculado em branco e vermelho da pista de Congonhas (10.5 $\mathrm{Km})$. A elevação Inter fluvial ocorre na cota 807 no bairro planalto paulista, mesma cota da pista do aeroporto. Ali, a proximidade da via expressa fez com que boa parte das casas se degradasse, fosse posta à venda ou virasse algum tipo de comércio.

Inicia-se a descendente, já na bacia do Tietê, pelo talvegue da antiga Avenida Água Vermelha, onde a Bandeirantes foi implantada. Deixando o acesso a Imigrantes para trás $(13.5 \mathrm{Km})$, atravessa-se a elevação da Avenida do Cursino, pelo longo, escuro e inóspito túnel Maria Maluf ( $15 \mathrm{Km}$ ), após o qual, segue-se em via elevada até tocar o chão bem próximo à avenida Nossa Senhora da Saúde, na cota 762, aproximando-se de um fundo de vale. Ali predominam grandes comércios, muitos das quais em franca decadência.

Elege-se a antiga estrada do Vergueiro para acessar a Anchieta (17 Km), saindo da cota 748 até a 792. Neste trecho, predominam casas e prédios residenciais entremeados por postos de gasolina 
e redes de "fast-food", preparando os viajantes do planalto para o percurso até o mar. Uma vez na Anchieta, segue-se em descendente até o Ribeirão dos Couros, divisa entre São Bernardo e São Paulo (20 Km).

A partir do encontro da rodovia com o Ribeirão, segue-se pela rodovia em suaves inclinações descentes e ascendentes, atravessando os diversos acessos ao ABC e tendo como companhia ora grandes lotes industriais, ora conjunto de torres habitacionais. No horizonte está o "Montanhão" e a favela do areião, ambos na cadeia do Parque Natural do Pedroso, divisor de águas do Rio Grande/Billings com o Tamanduateí. As principais montadoras pelas quais o ABC é tão conhecido vão surgindo ao lado, algumas com fachadas imponentes e estilosas, como a Karmann Ghia e a Scania, outras absolutamente inexpressivas, como a Renault $(30 \mathrm{Km})$. Uma fábrica quilométrica aparece antes do rodoanel: é a Volks, com um surfista e uma família feliz impressos na gigantesca fachada (33 Km).

Uma profusão de acessos, alças, placas e pontes anunciam a chegada do rodoanel, que praticamente coincide com o divisor de águas do Rio Grande. No acostamento, um significativo número de pessoas circulando à pé e de bicicleta em direção à Vila do Riacho.

Transposto o divisor de águas, inicia-se uma descendente de onde é possível se visualizar a represa. Ao se aproximar das águas vemos de um lado a antiga estrada do Vergueiro ${ }^{39}$ e de outro a Sabesp (36 Km).

Após esse trecho, a rodovia segue em aterro sob a represa até saída 29, único acesso à Vila do Riacho Grande. A rua principal "Heinrich Nordhoff", é

39. Neste trecho a Anchieta está descolada do antigo leito da estrada do Vergueiro, que tem um trecho ainda em terra batida que dá acesso aos bairros Jardim Jussara e Vila Balneária. O reencontro das duas vias se dá onde antes o caminho do mar atravessava o Rio Grande. um alemão no meio de um mar de ruas com nomes italianos: Caputo, Pinoti, Pelozini, Zampieri, entre outros. A homenagem foi feita ao engenheiro que reconstruiu a Volkswagen no pós guerra, e é também o eixo principal por onde se acessa a Rua da Praia. Ao fim da Rua da Praia se entrevê, pelos galhos da enorme Figueira, os restaurantes flutuantes e as colinas verdes da outra margem do Rio Grande. Não se chegou à praia, mas à Prainha (38 Km).

\section{História, memórias e Paisagem}

A Prainha do Riacho pertence ao Distrito do Riacho Grande e situa-se na porção sul do Município de São Bernardo do Campo, na área da Grande São Paulo, conforme figura 22. A área foi atravessada historicamente por alguns dos caminhos que ligaram o planalto paulista ao litoral e estão associadas ao momento em que São Paulo era um pequeno povoado no planalto de onde se partiam as bandeiras em busca de índios para trabalho escravo. Por essa razão é necessário considerar a importância de tais deslocamentos na formação deste território onde atualmente encontra-se a Prainha.

No período colonial, algumas trilhas indígenas foram aproveitadas pelos colonizadores e algumas delas foram batizadas por nomes que ainda hoje são utilizados, como o percurso de José de Anchieta, a trilha do Rio das Pedras e do Esteiro de João de Ramalho. Tratavam-se de trilhas bastante rudimentares para padrões europeus, conforme descreve padre jesuíta por volta de 1640:

"Não é andando que a pessoa faz a maior parte da viagem, e sim de gatinhas, com os pés e as mãos no chão, agarrando-se às raizes das árvores, em meio a rochas pontiagudas e terriveis precipícios, e meu corpo estremecia, devo confessá-lo, quando olhava 


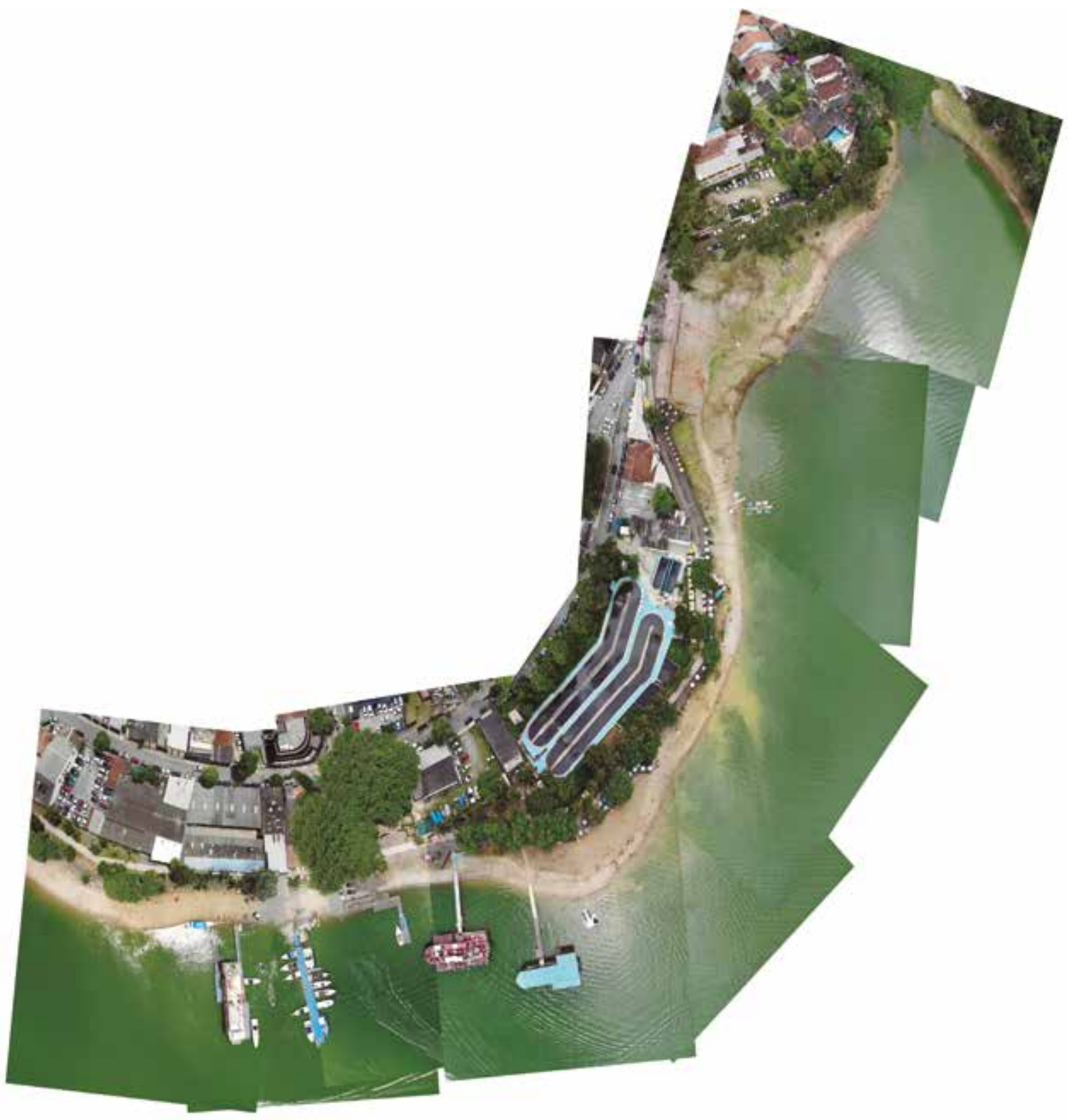

[21] Vôo Drone 2018

Carolina Gimenez e Michel Gubeissi 


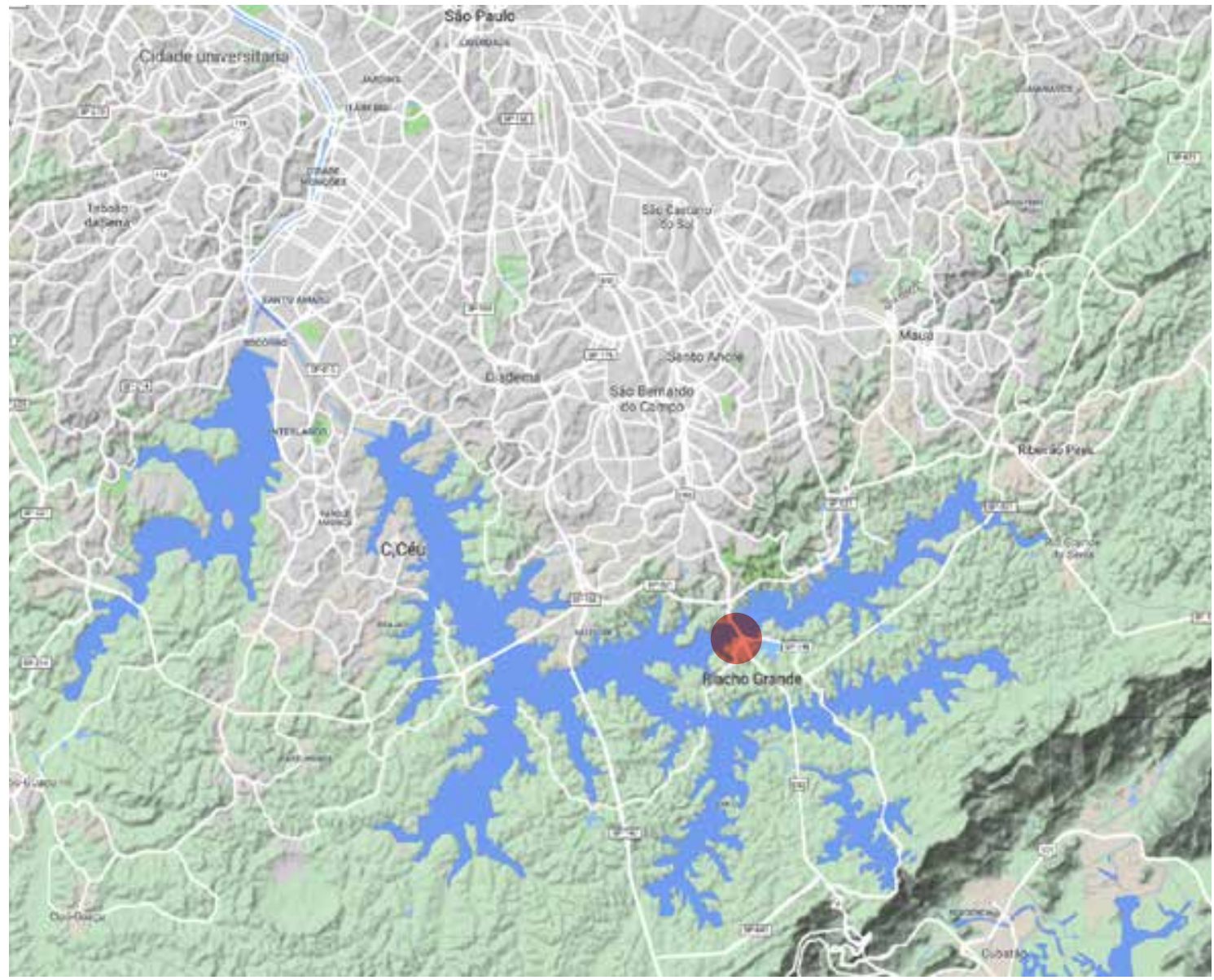

(1) $1 \mathrm{Km} \sqcup 5 \mathrm{Km}$

[22] Localização da Prainha do Riacho Grande.

Sem escala.

Base cartográfica: Google Earth (2018

Prainha do Riacho Grande

Mancha urbana

Principais eixos viários

Rios e Represas

Área não urbanizada

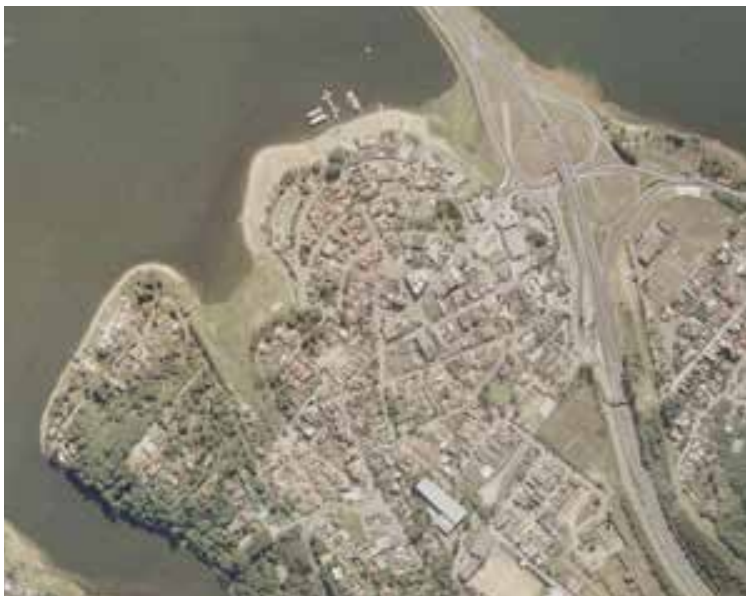

[23] Prainha do Riacho Grande.

Sem escala.

Base cartográfica: CESAD/FAUUSP 
[24] Linhas coloniais do Núcleo de São Bernardo (Santos, 1992)

\begin{tabular}{llll} 
Linha & Lotes & Ano & Bairros Atuais \\
\hline Galvão Bueno & 33 & 1887 & Demarchi e Batistini \\
\hline Jurubatuba & 79 & 1877 & Assunção \\
\hline Camargo & 12 & 1887 & Alves Dias, Vila Ferreira \\
\hline São Bernardo Velho & 19 & 1877 & $\begin{array}{l}\text { Estrada do Vergueiro, sede antiga } \\
\text { da Fazenda dos Beneditinos }\end{array}$ \\
\hline Rio dos Meninos & 23 & 1886 & Rudge Ramos \\
\hline Sede & 146 & 1877 & Centro \\
\hline São Bernardo Novo & 82 & 1877 & Pico do Bonilha, até Pque. do Pedroso \\
\hline Dutra Rodrigues & 29 & 1888 & $\begin{array}{l}\text { Cortada pela Estrada da Pedra } \\
\text { Branca, junto à Billings }\end{array}$ \\
\hline Rio Grande & 83 & 1888 & Billings e Bairro dos Finco \\
\hline Rio Pequeno & 70 & 1897 & Distrito de Riacho Grande \\
\hline Bernardino de Campos & 62 & 1894 & Distrito de Riacho Grande \\
\hline Capivary & 76 & 1891 & Distrito de Riacho Grande \\
\hline Dr. Campos Salles & 76 & 1897 & Distrito de Riacho Grande \\
\hline Curucutu & - & Distrito de Riacho Grande \\
\hline Voluntários da Pátria & - & Distrito de Riacho Grande (794) \\
\hline
\end{tabular}

para baixo. A profundeza do abismo é assustadora e a profusão de montanhas que vão surgindo sucessivamente parece deixar-nos sem nenhuma esperança de chegar ao final" ( Saint-Hilaire, apud DOS SANTOS, 1992, p.73)

Em uma dessas trilhas, percorria-se parte do trajeto por via fluvial pelo rio Cubatão na baixada santista, atravessando o trecho de serra à pé e atingindo o planalto novamente por canoas pelos rios Pequeno ou Grande e desembocando no rio Jurubatuba, hoje rio Pinheiros. Ao final do século XVIII com a intensificação dos deslocamentos de pessoas e cargas entre litoral e planalto, entre os anos de 1788 e 1792 projetou-se e construiu-se um novo acesso pavimentado homenageando o governador Bernardo José Maria de Lorena. Tal rota ficou conhecida como Calçada do Lorena.

Em meados do século XIX a calçada do Lorena foi substituída pela Estrada da Maioridade, posteriormente denominada Caminho do Mar. O que se conhece hoje como centro do Riacho, onde se localiza a Prainha, funcionou no período colonial como entreposto para viajantes na rota do Caminho do Mar ${ }^{40}$. É durante esse período da História em que são adotadas políticas de povoamento e distribuição de terras a imigrantes estrangeiros. Como parte dessa política são abertas linhas coloniais pelo Governo da Província de São Paulo, sendo 15 deles abertos em São Bernardo do Campo, conforme tabela acima.

Diferentemente de alguns núcleos coloniais em que colonos trabalhavam como mão de obra assalariada, as famílias de imigrantes italianos, poloneses e alemães instalaram-se na linha do Rio Grande como proprietários, em situação privilegiada em relação à província, estando em ponto intermediário entre

40. DOS SANTOS (1992). 


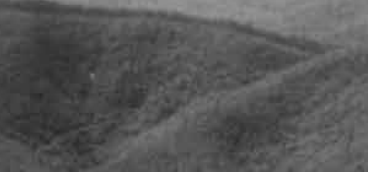

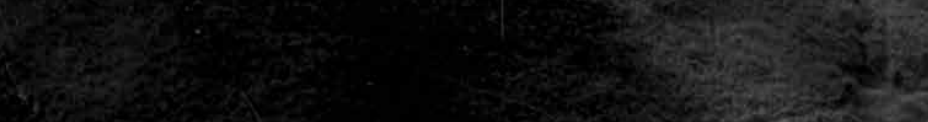
S. 3.

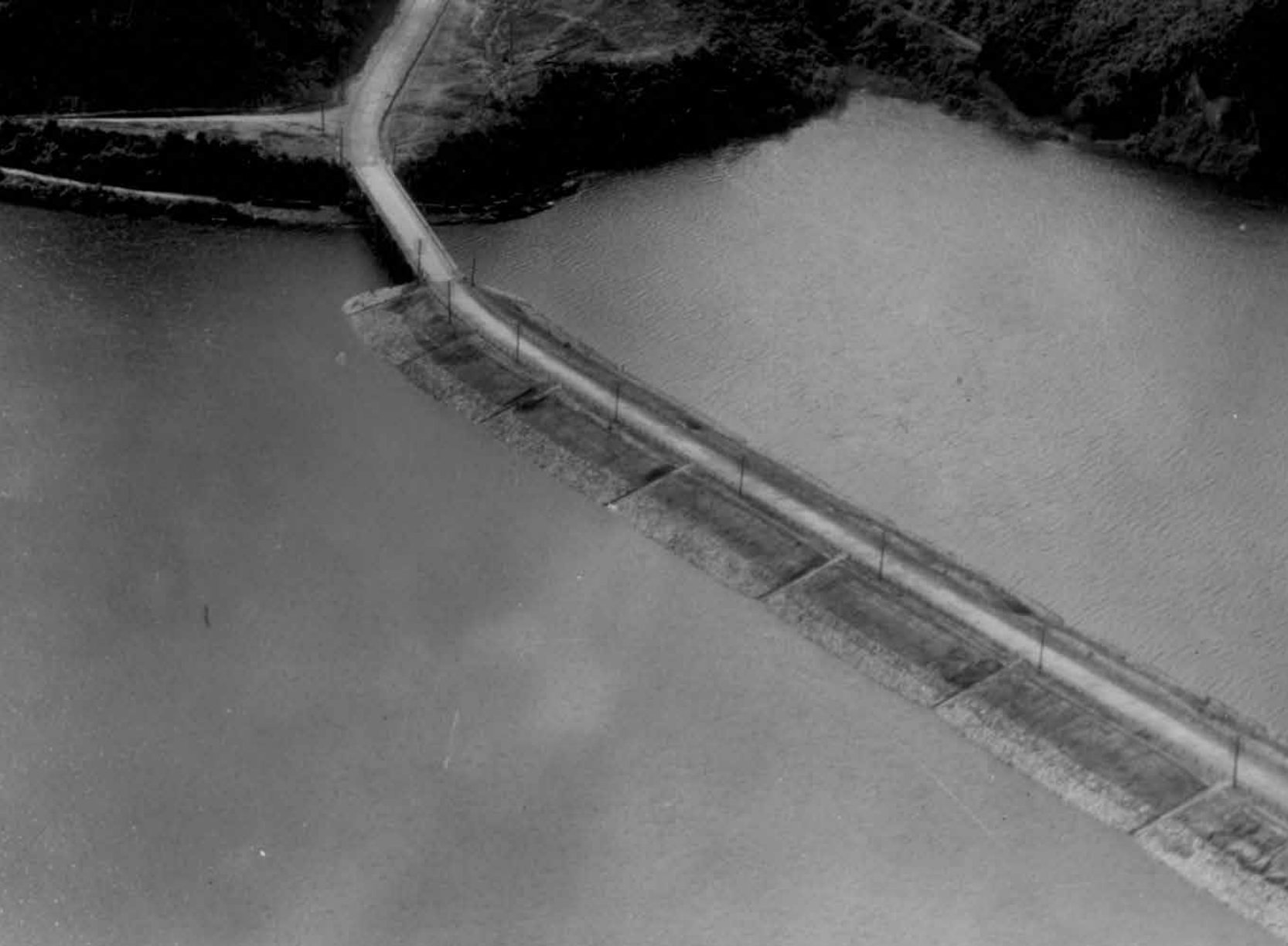




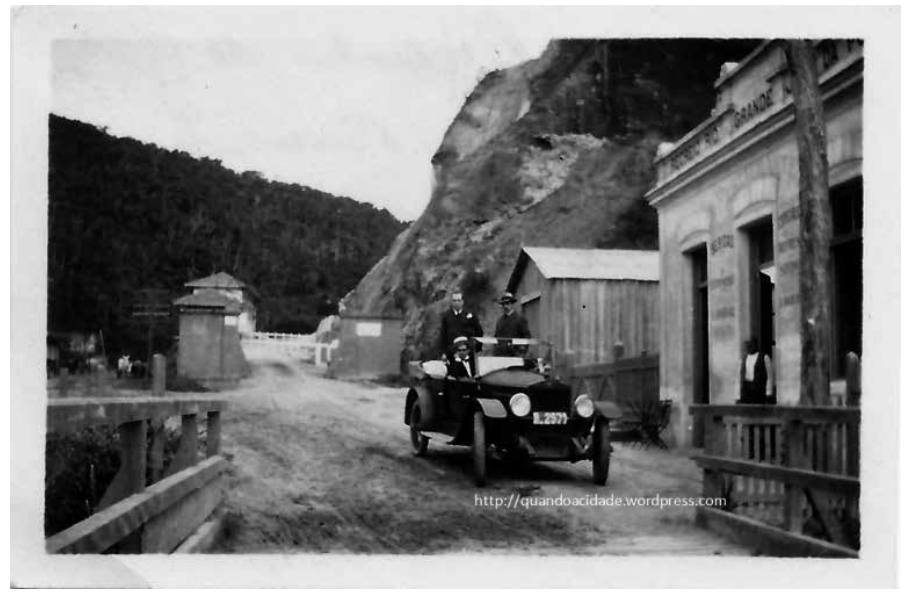

[25] Página ao lado: Trecho em que o antigo Caminho do Mar seria substituído pela Via Anchieta, na altura do encontro com a represa do Rio Grande. Ao lado esquerdo ainda se vê os remanescentes da antiga estrada do Vergueiro.

Sem data

Acervo Fundação Energia e Saneamento

[26] Placa onde se lê Recreio do Rio Grande, na travessia do rio grande - viagem de 1922 entre São Paulo e Santos

Fonte: < https://quandoacidade.wordpress. com> acesso em 22.03.2019 a cidade de São Paulo e o Porto de Santos, junto ao Caminho do Mar.

Há registros da ocupação antes da abertura da linhas coloniais do Rio Grande, com a abertura de uma serraria em 1856 sob propriedade da família Julien, considerado um dos primeiros empreendimentos dessa natureza na província. Com a abertura da linha Rio Grande outras famílias fixaram-se na área e com isso novas serrarias surgiram em pequenos sítios. Os sítios serviam tanto a produção de subsistência como produção de carvão vegetal. Assim, a paisagem da densa cobertura vegetal original foi sendo removida para o abastecimento de carvão para São Paulo, São Bernardo e Santo André.

Com as atividades extrativistas ligadas a madeira e carvão, configurou-se um pequeno núcleo urbano com porto fluvial próximo ao encontro do Rio Grande e ponte do antigo Caminho do Mar. A esse núcleo deu-se o nome de Vila do Rio Grande, e abrigava algumas casas de colonos, mercearias e restaurantes. Havia, na memória de Leli (Quirino Vicentin), um restaurante implantando ao lado da ponte cujo proprietário, João Cavinato passou a ser conhecido como João da Ponte. A vila, com aproximadamente
150 casas, se organizou no entorno próximo a atual estação de tratamento da Sabesp. Lembra Leli:

"LELI: Essa ponte foi feita quando a água começou a aparecer por aqui, o meu irmão ainda lembra que ele ia com o caminhão do meu pai, ali onde tem a caixa d'água (Sabesp), e a rua bem por baixo, ali tinha uma subida, tinha um restaurante do João da ponte, a gente apelidava de João da Ponte CAROLINA: Porque ele estava do lado da ponte? LELI: É, porque ele estava do lado da ponte, já tinha uma pontinha muito vagabunda, e o rio passava por baixo. Depois que fizeram a via Anchieta, essa via Anchieta acho que começaram a fazer em 1930, 1929, porque a água ia tomar toda aquela rua"

A madeira extraída pelos colonos era transportada pelo leito do rio e depois seguia por tropas para as olarias e serrarias. A essa época, com o declínio do tráfego entre planalto e litoral através da região da Vila do Rio Grande e substituição do mesmo pela estrada de ferro "São Paulo Railway" os imigrantes da região ficariam relativamente isolados até mesmo após a restauração do Caminho do Mar entre 1913e 1920 e 
[27] Captação de água da Sabesp.

Acervo fundação energia e saneamento Sem data

sua concretagem em 1925, mesmo período em que a vida dos imigrantes seria diretamente impactada com a desapropriação de parte de suas terras para a construção do reservatório do Rio Grande. Leli conta das dificuldades em trabalhar com extração e transporte de madeira nesse período:

LELI: Tinha muita gente que morava nesses matos e com a machadinha eles cortavam a lenha, tratava três, quatro fios, era uma vida dificil, mas não tinha outra coisa. Aqui não tinha energia, foi em 1957 quando esse ai nasceu (aponta para o filho mais velho) que chegou. Ele tinha três dias quando a energia chegou

CAROLINA: Quando o senhor comprou o motor? LELI: Em 1945 que eu comprei uma lancha com motor para puxar o batelão ${ }^{41}$

CAROLINA: teve um momento antes do motor que o senhor ia no remo mesmo?

LELI: É, nós íamos em dois, era difícil.

CAROLINA: Eu imagino.

LELl: Nós remávamos 6 h sem parar, saia lá para cima

41. Tipo de embarcação de fundo chato, com pequeno calado, própria para operação próxima a margens de rios e represas. da balsa 6h da tarde, chegávamos aqui na prainha meia noite remando.

CAROLINA: Por que além de tudo a represa é tão grande que em alguns lugares pega muito vento... LELI: Pega, e quando o vento não dava contra? Se dava contra, tinha que encostar em um barranco se não ao invés de remar para frente, o vento levava para trás.

SOLANGE: E tinha a época da neblina né pai? Conta para ela.

LELI: A neblina é triste.

CAROLINA: Mas tem uma época ou é sempre assim? Porque a gente está quase no pé da serra. LELI: A neblina aparece mais em dias mais curtos. SOLANGE: Mas antigamente dava mais neblina e mais semana de garoa do que hoje. Eu tenho essa recordação de quando eu era criança que garoava umas duas semanas sem parar. Equando abaixava essa neblina, muitas vezes ele tinha que dormir no barco. Não tinha por onde andar.

LELI: Não tinha celular, não tinha GPS, não tinha nada. Se o vento segurava mesmo a gente, a comida ia acabando... 


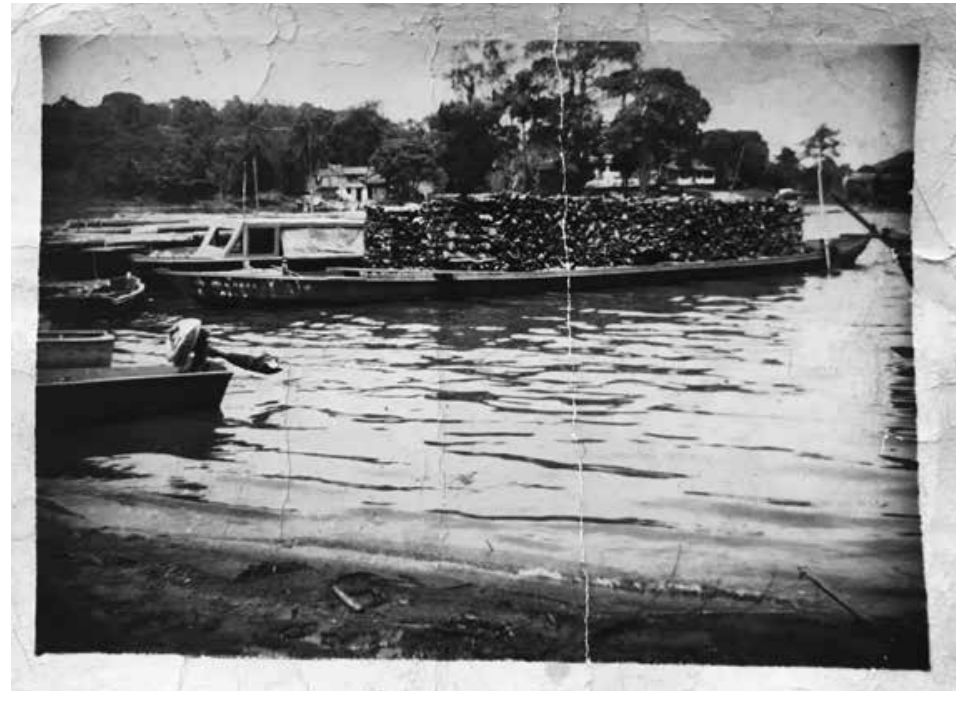

[28] Batelão do Sr. Quirino aportado no Riacho Grande Sem data Quirino Vincentin (Leli)
O impacto do represamento do Rio Grande não seria sentido imediatamente pelos moradores, uma vez que levou alguns anos até a cota do espelho d'água subir os 25 metros do projeto. Leli afirma que a represa só começou a aparecer no Riacho em 1933, e que alguns moradores inclusive se recusariam a aceitar as mudanças, como conta Leli:

CAROLINA: Como foi o processo de formação da represa? você consegue lembrar? e quem tinha terra perto do rio? O que fez?

LELI: Meu pai mesmo tinha, eles indenizavam. Se quisesse vender, combinar tudo bem, se não a água ia enchendo...

CAROLINA: Não tinha muita escolha...?

LELI: Vou falar uma história para a senhora: Tinha um morador teimoso, João Mendes, tio da nossa mãe, ele tinha uma casa que a água ia chegar, mas quase por último, e ele teimoso falando: "Eu daqui eu não saio, quero ver se alguém vem tirar meus filhos daqui, quero ver", e falamos: "ninguém vai tirar seus filhos dai, o senhor vai ter que sair". Ai quem fez a mudança dele? Eu com o batelão...

CAROLINA: A água estava na porta então?
LELl: A água já estava batendo no assoalho, e a rua para chegar caminhão já tinha sido invadida pela água. Fui com o batelão, carregamos a mudança dele e trouxemos aqui no Largo Azul, porque esse terreno do Largo Azul era do João Mendes. Mas ele teimoso falando "daqui não saio, quero ver quem me tira" falei: "Ninguém vai tirar seus filhos daí e jogar fora, uma hora ou outra você vai ter que sair".

Com o represamento do rio, alguns moradores se deslocaram para a parte alta da Vila, atualmente denominada Vila do Riacho Grande, e outros se deslocaram para o centro de São Bernardo. A represa chegou ao centro do Riacho Grande em $1933^{42}$. Até então o transporte de madeira era feito majoritariamente por canoas. Com o aumento da superfície alagada e intensificação da atividade de extração de madeira para alimentar algumas indústrias nascentes em São Bernardo, o transporte por canoas foi sendo substituído pelos batelões e lanchas.

Ao final da década de 40 , outra grande obra transformaria intensamente a região. Em 1947 inicia-se a

42. Segundo Leli, em entrevista a autora. 


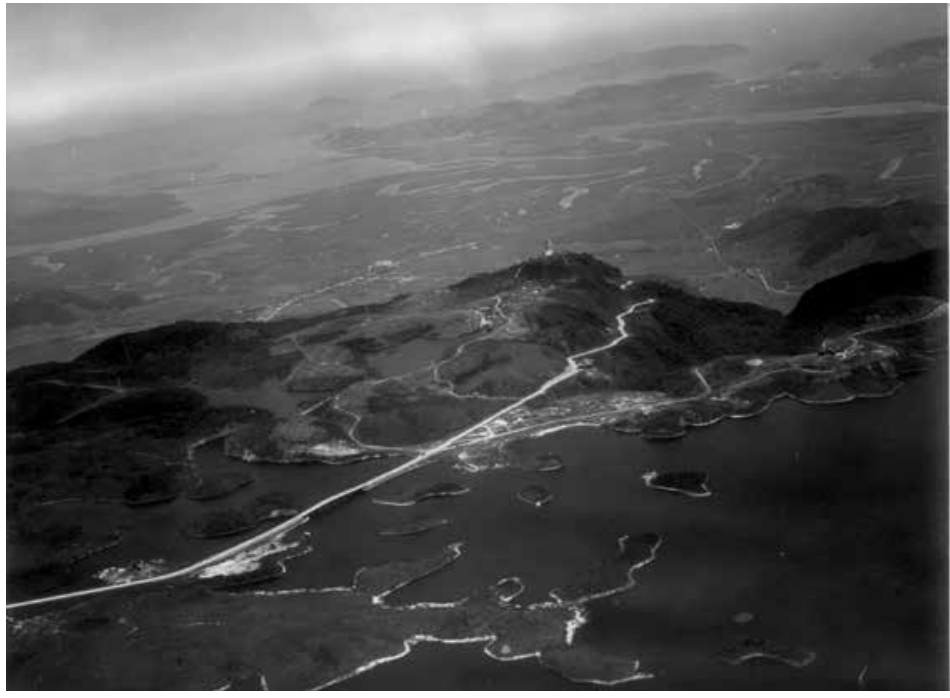

[29] Rodovia Caminho do Mar Sem data

Acerrvo Fundação Energia e Saneamento construção da Via Anchieta, a primeira estrada a ligar a baixada ao planalto com traçado planejado para o uso de automóveis. A construção da via fez parte de um projeto político para controle administrativo e fiscal dos territórios do $\mathrm{ABC}$ como vetor de organização da produção industrial e exportação por Santos. A via, que se aproveitou de alguns trechos do Caminho do Mar, proporcionou o adensamento do centro do Riacho Grande e criou alguns núcleos residenciais em seu entorno que passaram a fazer parte do território. Em 1948 ganhou status de Distrito.

Com acessos facilitados pela rodovia, as propriedades rurais da Vila do Rio Grande passam a ser desmembradas em lotes menores, a exemplo do loteamento onde encontra-se a Prainha. Em 1953 é aprovado o loteamento Parque Rio Grande, cuja gleba, é adquirida da família italiana Caputo por três proprietários: Abrahão Sabbá, Aldhemar Ferrero e Elias Aun. É dividida em 175 propriedades de médio a alto padrão variando entre 250-400 metros quadrados e tem as ruas paralelas à represa do Rio Grande batizadas com nome de rios brasileiros. $\mathrm{O}$ loteamento se acomoda suavemente na topografia em forma de leque, e foi projetado com ruas amplas e arborizadas, no entanto, ocupou a faixa de primeira categoria ${ }^{43} \mathrm{em}$ frente a represa, bloqueando o contato visual com o espelho d'água, que somente pode ser visto através do eixo principal formado pela Rua da Praia.

No período seguinte, já com a presença da Via Anchieta, se intensificaram a venda de lotes junto à represa. A área do Parque Rio Grande devido sua localização privilegiada teve forte valorização imobiliária. Com a construção de casas de campo e pequenas chácaras para pessoas de alto poder aquisitivo de São Bernardo, a represa começou a ser explorada para turismo e lazer. Antigas vocações foram abandonadas, com o fim da extração de madeira, fechamento das serrarias e término da produção de carvão vegetal, com áreas de extração e cultivo sendo progressivamente recobertas por mata secundária.

LELI: Ia pescar no rio antes da represa, depois com o tempo meu primeiro trabalho foi puxando lenha aí

43. Faixa de primeira categoria é aquela definida pela lei 1172/76 em 50 metros a partir da cota máxima de alagamento da represa (747), de onde se deve desenhar uma linha paralela. 


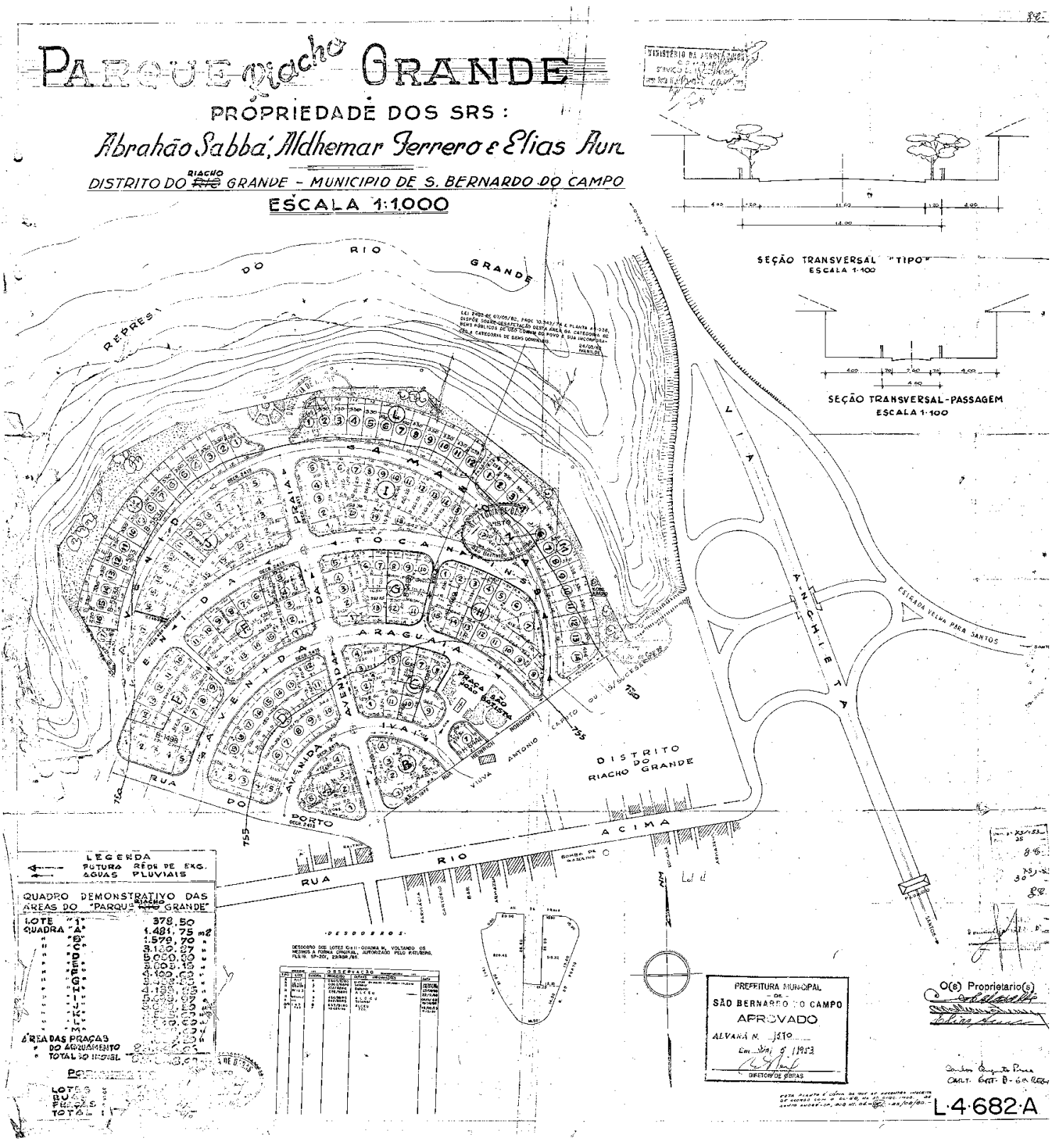

[30] Planta do loteamento "Parque Rio Grande", posteriormente denominado "Parque Riacho Grande"para se diferenciar do município de Rio Grande da Serra. Pode-se identificar a Rua do Porto, por onde saiam os barcos e batelões de transporte de carga e pessoas. 


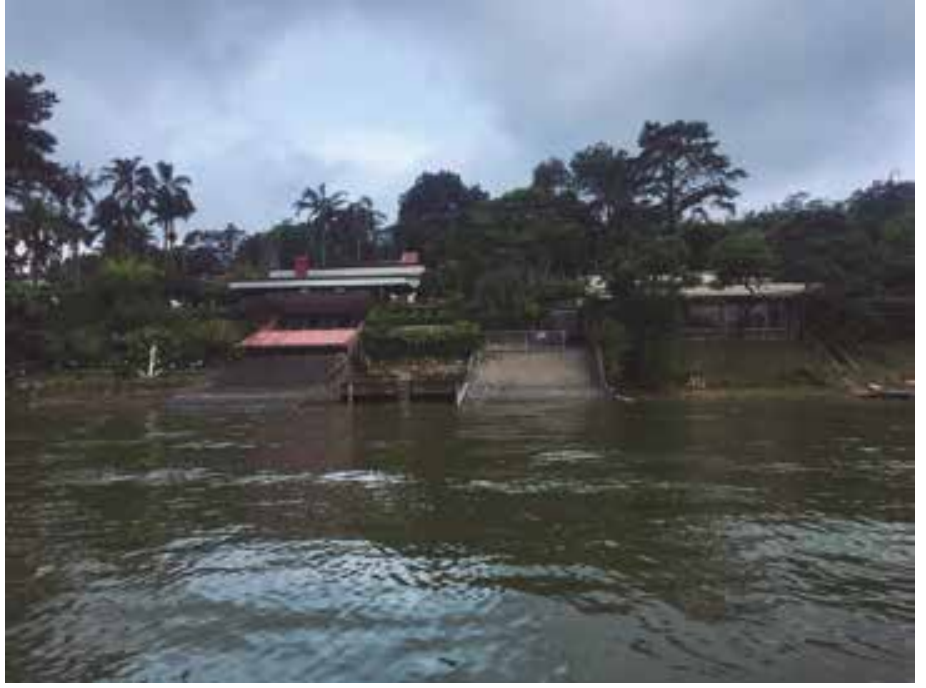

[31] Residência de Alto Padrão próxima à Prainha Carolina Gimenez, 2018 nos batelão com meu cunhado, logo após comprei barco... Antes de 1945 trabalhava no remo carregando esse "barcão" com 60 metros de lenha em dois, depois de 45 comprei uma lanchinha e trabalhei até 1962 na represa. Daícomprei um caminhão até completar os 84 anos, fiquei trabalhando com ele, e agora não estou fazendo nada.

O novo eixo econômico que se formou na Anchieta entre São Paulo e a Vila do Riacho, com forte presença da indústria automobilística, resultou, de um lado, na formação de bairros populares, com pouca ou nenhuma infraestrutura e por outro, reservou, para uma elite que se formava, a orla fluvial da represa Billings. Em situação privilegiada de acesso a represa, o loteamento Parque Riacho Grande foi ocupado por casas de alto padrão e pouco tempo depois as embarcações simples e batelões foram substituídas por barcos de lazer.

A vocação da represa para usos de lazer fez com que se configurasse a partir da década de 70 a "rota do peixe": um circuito composto por restaurantes com menu dedicado a pescados, pesqueiros e lojas com produtos de pesca.
Nas décadas de 80 e 90 vieram os restaurantes flutuantes, as marinas e as motos-náuticas, trazendo um público de maior poder aquisitivo para a região. Esse foi o momento que o Riacho "ferveu", abrigando as "melhores baladas" ${ }^{4}$ para o público jovem de São Bernardo, que vinha passar as noites na Vila do Riacho ou andar de "jet" na represa.

Mesmo com o grau alarmante de poluição oriunda da operação de bombeamento do rio Pinheiros e suas consequências para a qualidade da água da represa, a Prainha manteve-se como ponto de encontro de pessoas de diversas origens da metrópole. Por outro lado, a deterioração das águas fez com que clubes e chácaras para fim de semana fossem abandonados e se iniciasse um movimento de periferização com parcelamento irregular de lotes para venda de terrenos com pouca ou nenhuma infraestrutura sanitária, agravando a qualidade de água do balneário.

O distrito encontra-se atualmente numa área de expansão urbana de São Bernardo, com acessos

44. Assim foi descrito por Marco Aurélio, arquiteto que fez o projeto de urbanização e morador de São Bernardo do Campo. Segundo ele, as melhores "baladas" de São Bernardo aconteciam na Vila do Riacho. 
facilitados pelo km 29 da rodovia Anchieta e distante $1 \mathrm{~km}$ do acesso ao rodoanel. No mapeamento proposto pela lei 13.579 estão presentes 3 tipologias de ocupação: Subárea Urbana Consolidada, Sub-área Urbana Controlada e Sub-área de Ocupação especial, cujas diretrizes principais são por ordem: controlar adensamentos, impedir novos loteamentos e investir em infra estrutura urbana, notadamente investimentos na área de saneamento.

Aos sábados e domingos a Prainha, tal como é conhecida, enche. Famílias, esportistas, pescadores e banhistas vem aproveitar o final de semana na orla fluvial. A inauguração do rodoanel no trecho Sul (2010) e principalmente Leste (2014) facilitou a conexão com áreas densamente populadas da RMSP. Por ser uma opção de fácil acesso e com taxas de pedágio mais baixas que as praticadas para a descida da serra, tornou-se bastante popular e é muito comum ver veículos com placas de diferentes municípios parados nas ruas e estacionamentos do entorno.

O relevo suave que se rebate para dentro é incomum: na maior parte da represa há uma predominância de grandes inclinações próximas à água e muitos casos de afogamento ${ }^{45}$ relatados. É uma área mais segura e adequada para crianças, sendo comum vê-las brincando nas margens. Alguns anos antes, em 2011, houve um avanço significativo na rede de coleta e tratamento do esgoto do bairro, porém optou-se por ampliar em frente à orla uma antiga estação de tratamento de esgoto que seria desativada ${ }^{46}$.

45. Alguns casos registrados entre novembro e dezembro de 2018 http://tvmaisabc.com.br/urgente-garoto-de-15-anos-se-afoga-em-represa-na-estrada-do-pedroso/

https://www.dgabc.com.br/Noticia/2979923/registrada-mais-uma-morte-na-billings-em-sao-bernardo

https://g1.globo.com/sp/sao-paulo/noticia/2018/11/20/policia-in vestiga-5-mortes-por-afogamento-em-represas-na-zona-sul-de -sao-paulo.ghtml

46. https://www.dgabc.com.br/Noticia/323641/estacao-de-riacho-
Para além da degradação ambiental causada pelo mau cheiro, a estação em questão apresenta problemas da qualidade do efluente. Em nota através do portal transparência a Sabesp afirma que o efluente emitido pela ETE Riacho Grande chega a $87 \%$ de eficiência na remoção de carga orgânica ${ }^{47}$, ou seja, chega a tratamento secundário, porém em área em que se tem contato direto com a água, o tratamento precisaria ser mais eficiente, devendo chegar a algo em torno de 98\% . Segundo Amauri:

"Supondo que chegue aos $87 \%$ de remoção, que considero inadequado para mananciais, isso ocorre quando a estação opera com a maior eficiência possivel. Têm duas alternativas viáveis: substitui-se esse sistema por um outro sistema radicalmente diferente - existem hoje sistemas que fazem o tratamento por membranas filtrantes com eficiência muito boa e que podem ocupar um espaço pequeno-ademais essa ocupação do Riacho Grande onde caem esses esgotos não é tão grande, tão significativa. A outra solução é levar os esgotos dessa área para outro lugar, atravessá-lo sobre a via Anchieta e chegar até o coletor tronco"

As principais contribuições de cargas orgânicas nesse trecho da represa vem dos bairros Areião, Vila Pelé ${ }^{48}$, Vila Balneária, Jardim Jussara e Jardim Tupã.

-grande-vai-tratar-esgoto.

47. Segundo a Sabesp, através do portal transparência no dia 15.02.2019 "O tipo de tratamento aplicado na ETE Riacho Grande é biológico aeróbio, através de Valos de oxidação, que promovem o tratamento dos esgotos a nível secundário. A eficiência média de remoção de carga orgânica, medida em Demanda Bioquímica de Oxigênio, obtida em 2018 foi de 87\%". www.sic.sp.gov.br

48. Informação de moradores da Vila Pelé é de que existem duas redes de esgotos, uma delas implantada pela Sabesp recentemente e outra, executada pelos próprios moradores, que na década de 80 recebeu "ajuda"de políticos de São Bernardo, que doaram material para as obras. Essa rede está numa cota abaixo da captaçāo da Sabesp e drena os esgotos diretamente para a represa. 
Segundo a Sabesp ${ }^{49}$ apenas Jardim Jussara e Areião não são atendidos com Sistema de Esgotamento Sanitário, que deverá ser implantado através do Projeto Tietê com previsão de implantação até 2022. Dificilmente essa meta será atingida se o plano de saneamento não vier integrado ao processo de urbanização das áreas, que atualmente encontrase suspenso ${ }^{50}$.

Os técnicos consultados ${ }^{51}$ divergem sobre a possibilidade de se melhorar a condição local da qualidade da água que banha a Prainha. Para Amauri, é possivel considerar que o tratamento integral de esgotos da área indicada acima poderia trazer condições de balneabilidade para a Praia:

"No corpo central da Billings a qualidade da água vai melhorando à medida que a represa se aproxima da serra do mar e do Rio das Pedras. Também o Rio Pequeno é um braço bastante bom em termos de qualidade, mesmo estando ligado ao corpo central. Se tiver um tratamento de esgotos, ou um trabalho de afastamento e coleta nessa sub bacia do Riacho Grande onde está a Prainha, pode se transformar em 'banhável' esse espaço".

Para Ricardo, é difícil estabelecer uma relação de causa e efeito entre tratamento do entorno e balneabilidade da área:

"Não sei dizer qual nivel de tratamento seria suficiente para a balneabilidade naquela área. A qualidade final do corpo receptor tem a ver parcialmente coma

49. Via portal transparência.

50. Amauri Pollachi em entrevista esclareceu que havia um contrato entre o Banco Mundial e a Prefeitura de Sāo Bernardo que foi encerrado pelo banco. Atualmente existem os projetos executivos e orçamento, mas não há previsão de início das obras.

51. Ricardo e Amauri respectivamente. qualidade do efluente lançado. Vai depender muito da hidrodinâmica e das condições de diluição. O reservatório Billings é complexo e não dá para estabelecer de antemão uma relação de causa e efeito entre o nível de tratamento e a qualidade do corpo. Pode ser que o tratamento primário seja suficiente naquela situação, mas de fato o padrão de lançamento deve ser adequado ao que estabelece a Resolução CONAMA 357 / 2005 e, mais especificamente a CONAMA $430 / 2011$, que trata exatamente dos padrões de lançamento"

A Sabesp afirma ${ }^{52}$ também que na Vila Balneária o atendimento é feito com sistema individual de tratamento (fossas sépticas). Na Vila Pelé embora a informação oficial seja de que há atendimento por rede de coleta de esgoto, a informação parece contradizer a situação verificada in loco do córrego que está a jusante da Vila e que chega diretamete à represa ${ }^{53}$.

A visita técnica a ETE Riacho ${ }^{54}$ corrobora a hipótese de Amauri Pollachi que dificilmente se chega a remoção nominal, pois levanta suspeitas sobre a capacidade da estação trabalhar na maior eficiência possivel. A ETE está trabalhando no limite de capacidade o que faz com que em dias de chuva, quando por deficiência na rede de coleta de esgotos ${ }^{55}$ se aumenta

52. Por meio do canal de comunicação portal da transparência

53. Para o trabalho de qualificação em abril de 2018 foi feito um estudo de implantação de Infra-estrutura verde na micro-bacia da Vila Pelé e a observação feita em campo apontava para grande quantidade de esgoto presente no corpo d'água que corria cinza até encontrar o corpo principal da represa. Na ocasião, conversando com moradores antigos foi dito que haveria duas redes de esgoto no bairro: uma delas implantada recentemente pela Sabesp, e a outra implantada pelos próprios moradores, numa cota mais baixa que a rede da Sabesp e que segue para o córrego que deságua na Billings. Essa rede executada pelos moradores na década de 1980, quando se iniciou a formação do bairro, foi resultado de uma doação de material de construção de um vereador em troca de votos.

54. Visita realizada com autorização da Sabesp no dia 24.03.2019.

55. Essa deficiência se dá pelo fato de ser comum, principalmente em loteamentos mais antigos, águas pluviais serem ligadas na rede de esgoto, o que faz com que o volume que chegue nas ETEs seja 


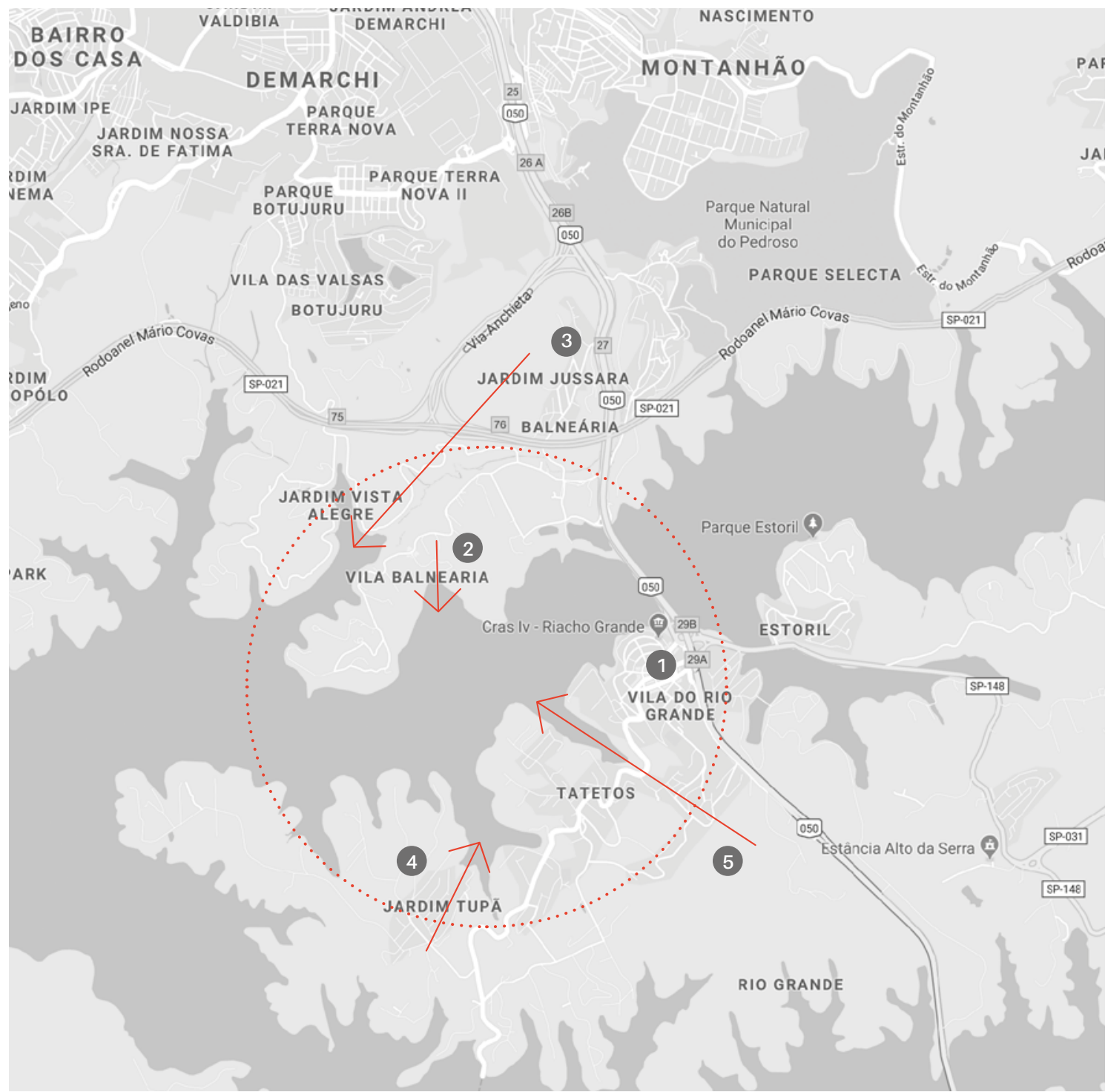

[32] Delimitação da bacia de contribuição

Carolina Gimenez, 2018

Base: Google Earth

\section{$\vdots \quad \vdots \quad$ Área de contribuição}

1. Vila do Riacho Grande

2. Vila Balneária

3. Areiāo / Jd. Jussara

4. Jardim Tupã

5. Vila Pelé 
a vazão de entrada na estação, a velocidade necessária ao tratamento não seja respeitada, podendo levar uma carga orgânica de saída bem maior que admitida, para evitar um dano ainda maior que seria o extravasamento de efluente nos tanques de oxidação, em outras palavras, o alagamento da ETE. A antiga estação foi projetada para atender apenas o loteamento Parque Riacho Grande e está atendendo atualmente a Vila do Riacho Grande, a Vila Pelé e Vila Tupã.

Não obstante a complexa hidrodinâmica do reservatório e os problemas identificados no tratamento de esgotos na ETE Riacho Grande, entre os meses de janeiro e fevereiro, a Prainha esteve própria para banho desde a semana que antecedeu a procissão náutica de Nossa Senhora dos Navegantes em 02.02.2019 até o início de março ${ }^{56}$. É possível que o aumento significativo dos índices pluviométricos associados a distância dos focos mais intensos de poluição tenha contribuído para a diluição de contaminantes na microbacia, alterando por completo o aspecto da água e da Praia. Nesse período, a represa subiu próxima a sua cota máxima, e se manteve menos túrbida porém mais escura, diferente do aspecto verde fosforescente em que normalmente se apresenta, típico de corpos eutrofizados. Nesse período, até as vésperas no aniversário da represa em 27.03.2019 nas margens viam-se inúmeros alevinos e peixes adultos, indicando o aumento de oxigenação da água e melhora da qualidade. No entanto, uma grande mortandade de peixes no corpo central logo abaixo ao viaduto da Imigrantes 2 dias antes da represa completar 94 anos $^{57}$ pode indicar que a operação de bombeamento das águas do Pinheiros acionada para conter enchentes

maior quando chove.

56. Foram feitas consultas periódicas ao site durante todo o periodo da pesquisa https://qualipraia.cetesb.sp.gov.br/qualidade-das-represas/billings.phtml

57. https://www.dgabc.com.br/Noticia/3027927/morte-de-peixes-na-billings-preocupa-pescadores-e-ambientalistas das chuvas de Março já esteja carregando cargas poluidoras em direção a Prainha do Riacho.

\section{Projeto de urbanização}

O descaso com as questões de saneamento e infraestrutura de lazer na Prainha e a pressão da empresa EMAE (Empresa Metropolitana de Águas e Energia) por liberar a faixa de domínio da represa de carros e trailers levou, ao final dos anos 2000 que se iniciassem estudos para a "revitalização" da área. A área havia sido cedida pela EMAE em comodato para a Prefeitura de São Bernardo pela então Light em 1974 com o fim exclusivo de possibilitar "O acesso às águas, podendo todavia ser aproveitado para plantação de gramados, hortaliças, ou outras espécies vegetais rasteiras de ciclo rápido"58, em outras palavras, nada fixo ou definitivo deveria ser colocado na orla.

No decorrer dos anos, como era de se esperar de uma área de grande potencial paisagístico, houve grande apropriação da mesma para fins de lazer, em concordância com a EMAE, que autorizou eventos como festas e encontros, além de festejos relacionados ao distrito. Como também era de se esperar, por conta das atividades de lazer, comerciantes se instalaram na orla para atender a demanda das pessoas que vinham passar o dia na Prainha. Ao permitir, mesmo que tacitamente a instalação de trailers fixos na orla e não proibir o uso da mesma para estacionamento de carros a Prefeitura de São Bernardo feriu os termos do Comodato e após diversas solicitações verbais e formais promovidas pela EMAE sem resultado, a empresa, em 2009, ajuizou ação de reintegração de posse da área. ${ }^{59}$

58. Ver documento da EMAE no apêndice dessa dissertação. 59. idem. 
Durante a primeira gestão do prefeito Luiz Marinho (2009-2012) eleito pelo Partido dos Trabalhadores, iniciaram-se os estudos para realocar os comerciantes e fazer as adequações necessárias para manutenção de usos de lazer na Prainha. A proposta de reforma havia sido uma "promessa de campanha" e estava presente no programa de governo, como afirmou Nilza Oliveira, Secretária de Orçamento e Planejamento Participativo na gestão de Luiz Marinho, para quem o prefeito foi responsável por:

\begin{abstract}
"Assegurar em seu Programa de Governo e depois implantar toda a reforma área da Prainha. Um dos motivos é que até 2008 o desenvolvimento econômico tinha uma atuação fragilizada e não imprimia qualquer política de fortalecimento das vocações econômicas tradicionais da cidade. Também não investia em novas áreas de desenvolvimento como o turismo, serviços ou politica de trabalho e geração de renda e áreas como a Prainha no Riacho Grande, Parque Estoril e Parque Cidade da Criança (este último de grande valor simbólico no imaginário de pessoas que nem moram em SBC) estavam totalmente abandonadas"
\end{abstract}

Assim, foi aberta uma licitação em 2010 para projeto de duas áreas na represa: uma delas, acima da barragem Anchieta, no Estoril, e outra, abaixo da barragem, no Riacho Grande. Segundo Marco Aurelio, arquiteto responsável pelo projeto dentro do escritório que venceu a licitação, não se tinha muita clareza sobre o programa arquitetônico a ser adotado na Prainha, e que coube a ele "traduzir" alguns elementos "vagos" do Termo de Referência (TR) em um programa de necessidades claro, além do escopo da intervenção. A empresa na qual o arquiteto trabalhava, Urbaniza Engenharia venceu a concorrência, muito embora não tivesse especialidade em projeto de urbanização, a despeito de seu nome "de batismo", mas, segundo Marco Aurélio "tinha lá seus atestados, fez um preço bom e ganhou a concorrência". O arquiteto, que tinha experiência em projetos desse tipo, se tornou o coordenador do projeto dentro da Urbaniza, conforme relata:

"O urbanismo era minha experiência principal, e acabei me tornando coordenador do contrato com a prefeitura de São Bernardo. Terceirizamos muita coisa, mas éramos os coordenadores. O Termo de Referência era muito vago. Queriam uma proposta para a orla e para as ruas em volta; queriam incorporar conceitos como 'traffic calming'; tinha também que ter uma proposta de estacionamento e acesso à Prainha, o trevo de saída da Anchieta é muito complicado... Então, envolvia melhorias na região toda. Enão tinha nada de componente ambiental".

Em determinado momento, Marco Aurelio relata que a Prefeitura se posicionou a favor de retirar os trailers do "waterfront" e proibir o banho na represa, de forma que a Prainha se tornasse um belvedere, sem acesso à água.

"Aí, nesse meio tempo, apareceu um novo componente: o espaço deveria ser de contemplação e não de uso, porque a água era imprópria para o banho; e se era imprópria para banho, não tinha sentido instalar quiosques, pelo contrário. A prefeitura estava se posicionando durante a implantação do projeto. Decidiu tirar todo o comércio e proibir o banho. A represa seria utilizada só para contemplação e uso náutico".

Uma prainha sem acesso à água? Numa área da represa que historicamente vinha sendo usada 

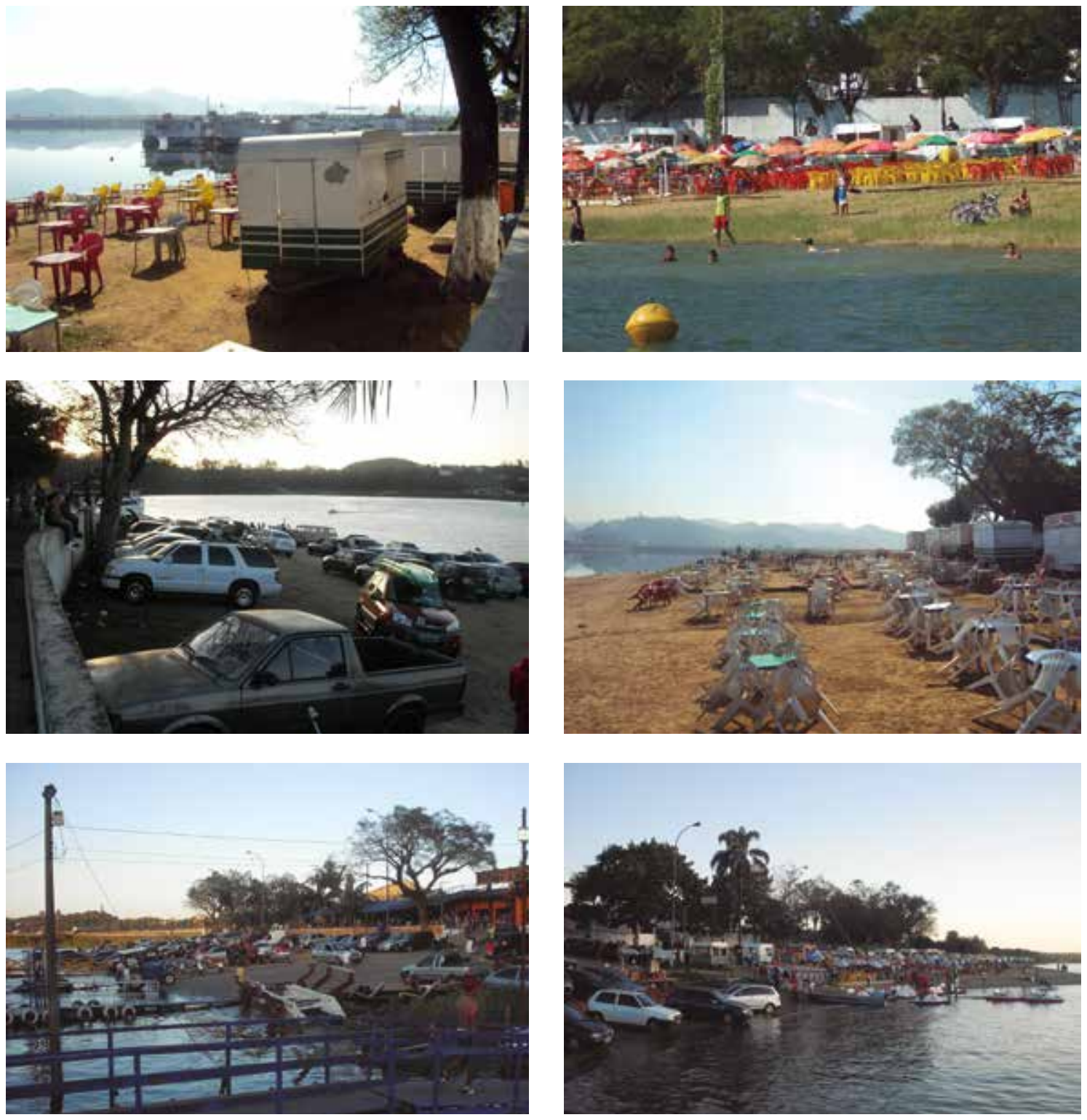

[33 a 38] Situação anterior ao projeto

Créditos das imagens: Urbaniza engenharia 


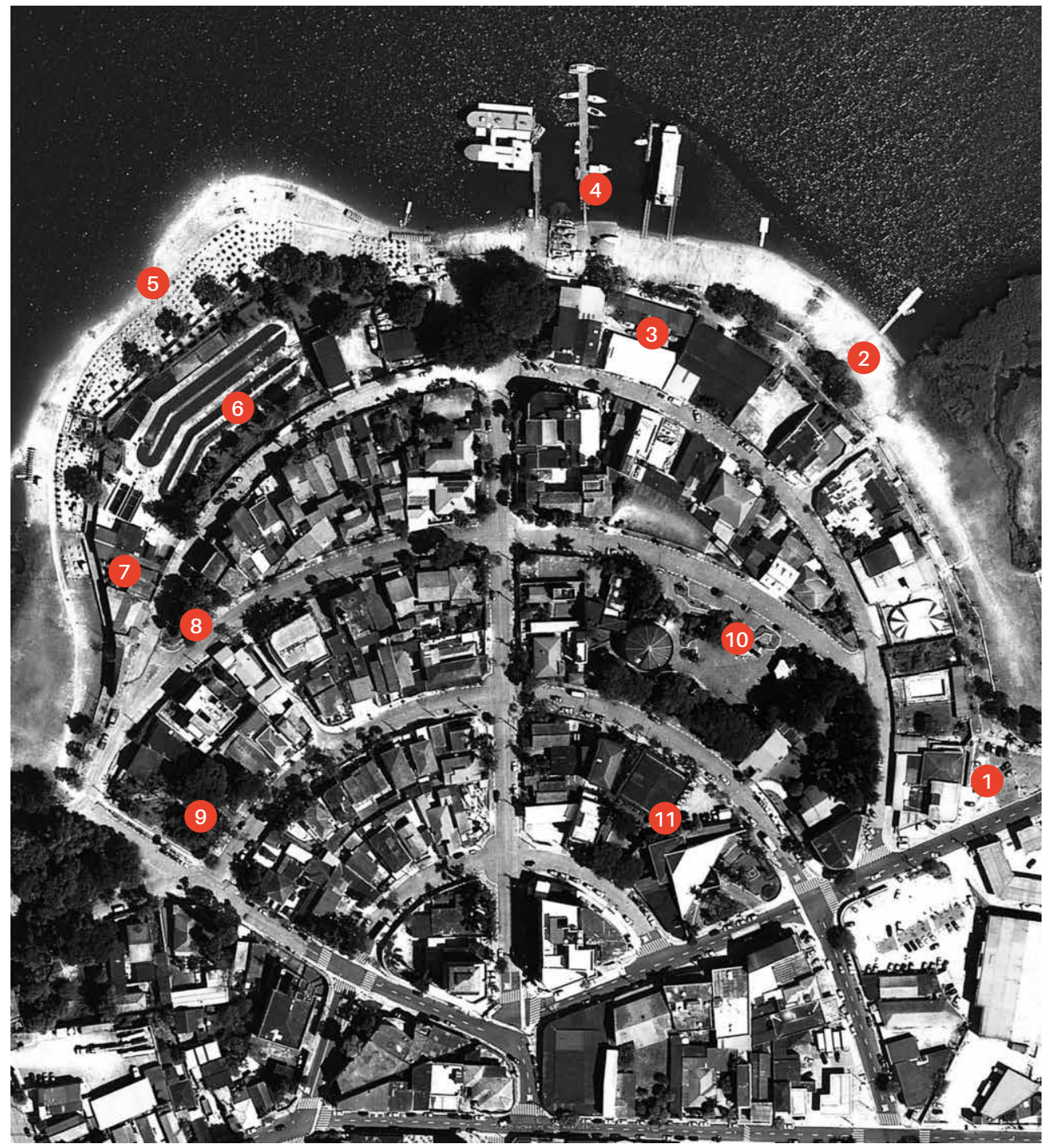

[39]

1. Estacionamento em área pública

2. Estacionamento no domínio EMAE

3. Ocupação de mesas no calçadão

4. Embarcações

5. Comércio na ocupação no domínio da EMAE

6. Estação de tratamento de esgoto - SABESP

7. Área pública - Casa da Biosfera

8. Área verde - Praça

9. Área verde - Praça e Polícia Ambiental

10. Área verde - Praça e Biblioteca - Feira verde

11. Subprefeitura do Riacho Grande

Créditos das imagens: Urbaniza engenharia 
como tal, a radicalidade de um projeto que se contrapunha aos usos já consagrados e que tinha como premissa impedir o acesso a água exigia uma postura severa de policiamento e controle por parte de agentes da municipalidade de São Bernardo, que no entanto, adotou uma postura contrária, liberando acessos do deck de contemplação à praia e possibilitando a instalação de quiosques em cima do deck, conforme relata Fernando Bonisio:

"Isso é protecionismo, assistencialismo barato que foi feito, deixaram ali quem não quer empreender. "Ah, porque é amigo daquele vereador, tal e tal." O projeto da Prainha foi feito para que fosse um deck de contemplação, já que não pode usar água, e aí no final da gestão passada, a subprefeitura autorizou várias construções de escada que não poderiam ser construídas. Não estou criticando, porque eu gostava do subprefeito, morreu já, não tem nem como se defender, mas quando eu fui falar com ele perguntei: "Por que fez isso?", e ele falou assim para mim: "Para ganhar a eleição a gente vende até a mãe"

Para além da discussão das práticas clientelistas tão entranhada na política brasileira, que são apontados por Fernando Bonisio e que precisariam ser melhor investigadas, cabe aqui uma reflexão: como um projeto que nega usos históricos e consagrados da represa poderia ser exitoso? A primeira impressão para quem desconhece o histórico de projeto é que ao caminhar pelo belvedere, parece que há um erro na cota de implantação do mesmo, que fica em alguns trechos 3 metros acima da cota máxima de alagamento da represa, gerando um lugar inóspito abaixo do si ao mesmo tempo que aparta totalmente as pessoas do espelho d'água, sensação reforçada pelas "escadinhas" que "pipocam" ao longo do per- curso. Outra ponto que "salta aos olhos" é : como questões de saneamento ambiental, fundamentais para melhoria da qualidade da água no balneário não foram ao menos colocadas como diretrizes para o projeto de revitalização?

Sob a ótica da organização e setorização propostas pelo projeto, havia uma previsão de acesso exclusivo para praticantes de esportes náuticos na extremidade da orla mais próxima a Anchieta, que afastaria o intenso movimento de descida e retirada das motos náuticas do eixo principal da Prainha na Praça Olavo Fontoura. Essa proposta faria com que o fluxo de tratores e carros de reboque fosse liberado da Rua da Praia, por onde a maior parte das pessoas acessa o deck, outro item que não foi executado na obra contratada. Essa setorização, estudada em conjunto com um estudo de tráfego detalhado contemplou estudos de sentido de ruas, vagas de estacionamento, alargamento de calçadas e estreitamento de vias.

A solução apresentada para a organização dos comerciantes que estacionavam trailers na faixa de domínio da EMAE, foi a proposição de um núcleo de serviços na Praça Bombeiro Giancarlo Massone, ao fim da Rua do Porto, que continha banheiros, vestiários e 4 unidades para servirem de lanchonetes. Também se propôs junto ao eixo principal na Rua da Praia o bloqueio para fluxo de carros, acessível apenas por pedestres e proprietários de imóveis, no intuito de incentivar que se tornasse uma rua de restaurantes e serviços. No canteiro central, haveria espaço para os trailers que outrora ocupavam a faixa de domínio da EMAE, além de banheiros públicos, vestiários e banheiros acessíveis. Nada disso foi executado. O projeto foi, nas palavras do arquiteto, "sendo destruído", e passou por cortes sucessivos de verbas, que inicialmente tinham "o céu como limite" e depois o dinheiro foi "encurtando". 


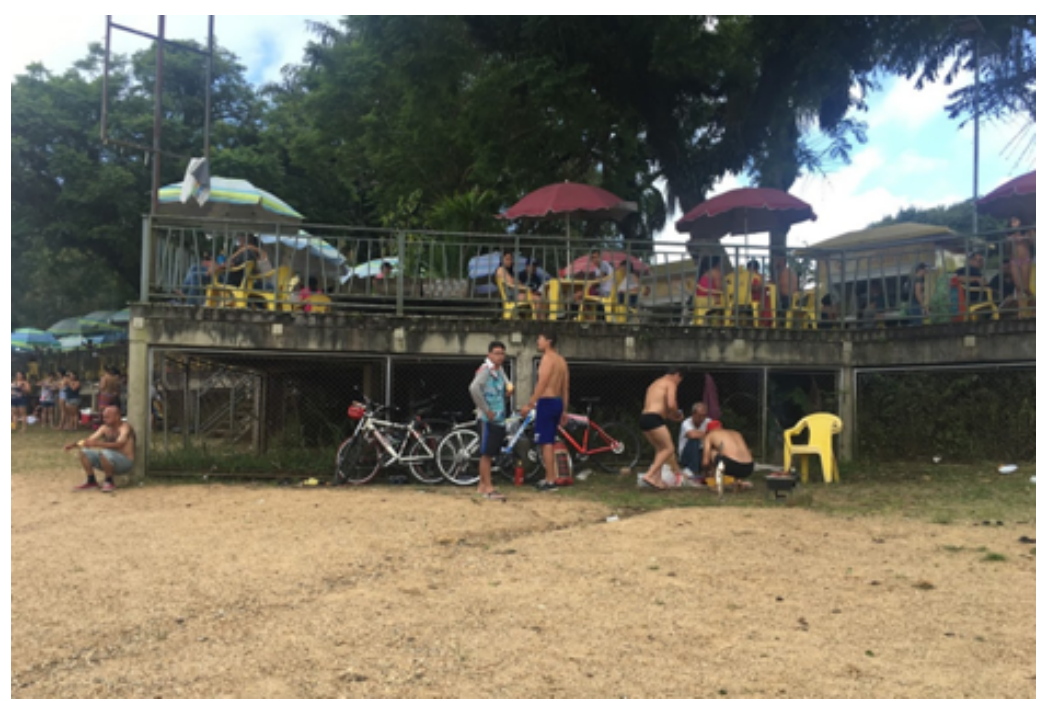

[40] Deck Suspenso Carolina Gimenez, 2019
De todos os problemas enfrentados, no entanto, a questão que "grita" é a solução adotada para a acomodar a solicitação dos comerciantes de alimentos de manterem seus pontos em frente a orla. Como apontado na análise do projeto do loteamento "Parque Riacho Grande" a área que seria de primeira categoria pela lei 1172/76, ou seja, os 50 metros a partir da cota máxima de alagamento da represa, foi ocupada por lotes residenciais, uma vez que o loteamento foi aprovado antes da referida lei. Assim, espaço entre a faixa de domínio da EMAE e os imóveis do loteamento praticamente inexiste. A solução encontrada pela prefeitura foi disponibilizar uma área junto a estação de tratamento de esgotos para implantação dos quiosques. Fernando conta:

"Com esses comerciantes dos quiosques, a gente fez umas 15 reuniōes, porque eles iam ser tirados de lá... Quais eram as condicionantes para a EMAE e a Cetesb autorizarem a obra? Você se lembra que tinham uns trailers? Uns trailers velhos, uns gatos de energia, era uma tragédia viva aquilo. Tinha que remover aquela situação de lá, resolver a situação daquelas pessoas, e não podia mais ter estaciona- mento, essas eram as condicionantes (...)E ai eles iam para essa rua da praia, e os moradores não quiseram, e os comerciantes não queriam, esse foi o problema. Então, o que a gente fez? Essa estação de tratamento de esgoto tinha dois metros para frente de muro, a gente recuou para poder colocar os quiosques. Então foi todo um trabalho, o único lugar que a gente conseguiu colocá-los, porque eles não queriam a Rua da praia"

Não parece razoável um quiosque de alimentos dividir muros com uma estação de tratamento de esgotos. Em um projeto de revitalização do porte que se pretendia, é a perfeita imagem do fracasso. Tampouco parece razoável, dentro das premissas de projeto, não estar contemplado a remoção da estação de tratamento de esgotos da orla. Ainda que isso pudesse ser uma meta a ser atingida futuramente ${ }^{60}$, deveria constar dos planos

60. Não se chegou a um consenso, com a Petrobrás, sobre dividir um espaço, junto ao oleoduto, para fazer a transposiçāo da Billings através de um coletor tronco que estivesse em nível com a Anchieta, que permitiria que o esgoto destinado a ETE Riacho se dirigisse a ETE ABC. A outra opção seria executá-lo abaixo do leito da Billings, obra extremamente cara, segundo informações do técnico responsável pela ETE Riacho. 

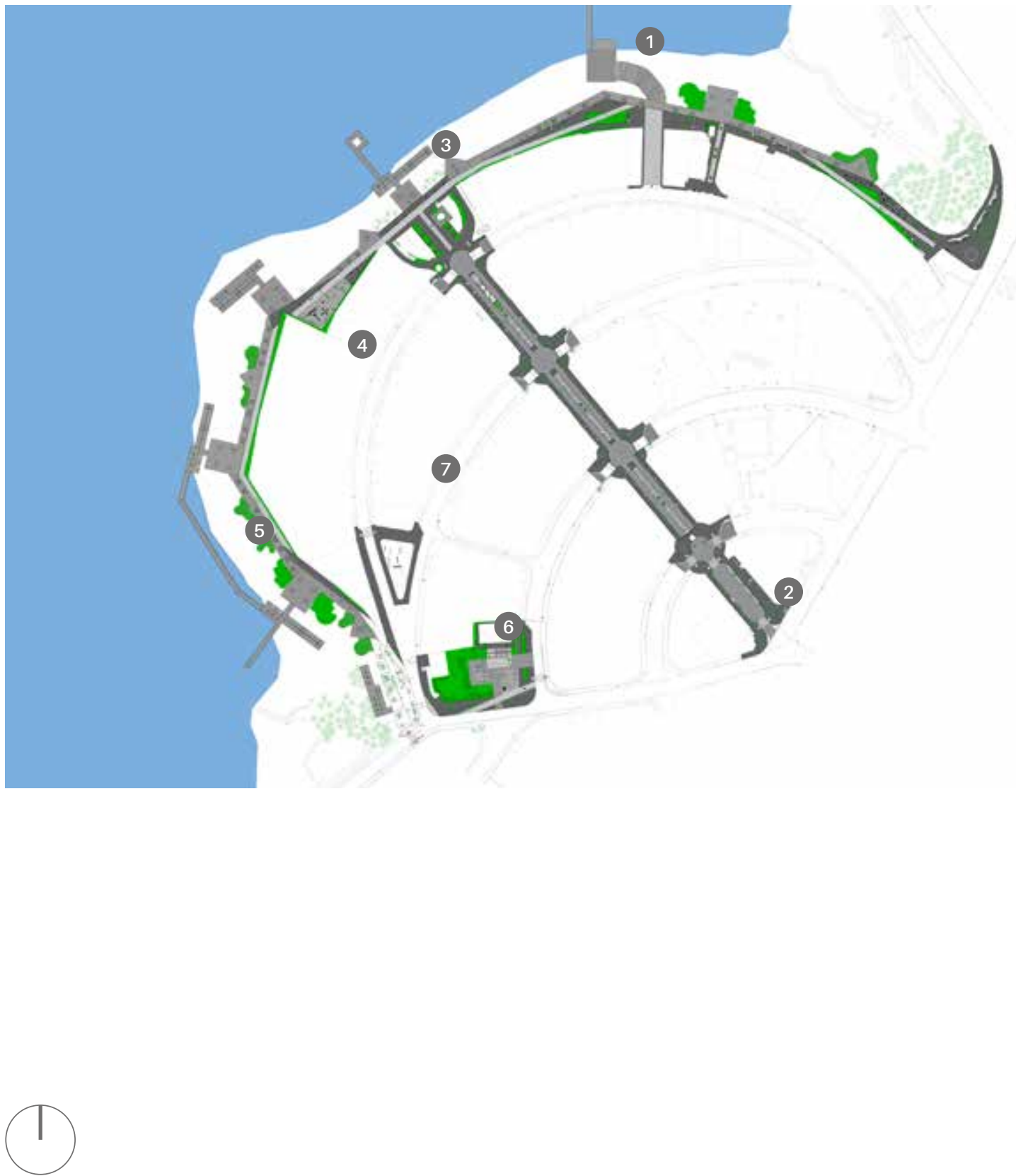

[41] Projeto de revitalização prainha do Riacho Grande

1. Acesso embarcaçōes

2. Rua da Praia: galeria

3. Praça Olavo Fontoura / Acesso de cadeirantes ao deck suspenso

4. Deck suspenso

5. Passarela suspensa sob a água

6. Praça de alimentação

7. Ginástica ao ar livre

Créditos da imagem: Urbaniza engenharia 
da Sabesp, que, ao contrário, planeja ampliar a quantidade de esgotos tratados naquela estação ${ }^{61}$. Essa percepção poderia estar relacionada a distância com que os vários agentes se relacionaram durante o processo, sem que houvesse tempo ou empenho no diálogo entre os diversos atores?

Assim, a praia, que aos finais de semana chega a receber até cinco mil pessoas ${ }^{62}$ fica tomada por um cheiro forte de esgoto e invariavelmente está imprópria para banho63, além de não possuir banheiros públicos adequados. O lugar da troca, da interação, da diversidade e convívio existe e é apropriado pelos usuários, porém não tem o devido suporte para atender a essas finalidades e se perdeu uma grande oportunidade para tal.

61. Em conversa no dia 10.04.2019 com Maria Carolina Gonçalves funcionária da Sabesp da Superintendência da Unidade de negócios Sul da Sabesp informou que já há um plano em andamento de expansão do volume tratado na estação, informaçāo confirmada por Sergio Shiguemi Semura, responsável técnico pela ETE Riacho Grande.

62. Estimativas da subprefeitura do Riacho Grande. Durante o festival de verão no entanto, as estimativas da guarda civil municipal, citadas em reportagem do canal G1 sugerem que o número tenha chegado a 10 mil $h$ ttps://g1.globo.com/sp/sao-paulo/noticia/2019/01/12/veja-a-programacao-do-festival-de-verao-da-prainha-do-riacho-grande. ghtml acesso em março de 2019.

63 Há um acompanhamento regular da Cetesb sobre a qualidade da água e placas com que orientam os frequentadores sobre a qualidade da água.. 


\section{Cantinho do Céu}

\section{O percurso}

Ao iniciar o percurso ${ }^{64}$ pela planície fluvial através da marginal Pinheiros tendo como origem a Cidade Universitária $(0 \mathrm{Km})$ e destino Cantinho do Céu, tem-se ao lado esquerdo o canal do Rio Pinheiros. Predomina na paisagem o relevo suave, com poucas alterações, até a usina elevatória de Traição $(5 \mathrm{Km})$, quando a via expressa se eleva e o canal se eleva 5 metros. Ao lado se vê 6 torres gigantes pertencentes ao complexo de luxo de arquitetura duvidosa ao qual o Shopping Cidade Jardim faz parte. Um pouco depois, em absoluto contraste, estão as modestas casas do Jardim Panorama (6,5 $\mathrm{Km})$, onde não se vê calçadas na divisa com a via local da avenida Marginal. Tendo o rio ao lado esquerdo, ao lado direito se vê a elevação do bairro Morumbi, com alternância de casas e prédios de luxo. Após 13 quilômetros atravessa-se o canal pela ponte Transamérica, percorre-se a planície agora com o rio ao lado direito. Ao passar por uma bela estação da CPTM (14 Km) integrada à linha lilás do

64. Ver nota 38 página 47 metrô ${ }^{65}$, é possivel enxergar o canal Guarapiranga, afluindo ao canal Pinheiros. A barragem Pedreira está próxima quando do lado direito aponta um morro de feições bastante uniformes, totalmente construído pelo homem. Foram percorridos $19 \mathrm{~km}$ até o aterro Santo Amaro.

Atravessa-se novamente o Pinheiros pela Ponte Vitorino Coulart da Silva: do lado esquerdo a barragem de Pedreira, com sua elevação de aproximadamente 25 metros acima do leito do rio e do lado direito uma ponte em estrutura mista de aço corten e concreto que vence o vão de aproximadamente 50 metros por onde os trens da Companhia Paulista de Trens Metropolitanos chegam à região entre os lagos Billings e Guarapiranga.

Saindo da planície da cota 723, a ponte eleva os automóveis cerca de 15 metros e desemboca na avenida Jair Ribeiro da Silva, que segue em aclive até atingir a cota 750, 3 metros acima do espelho d'água da represa (747), e segue paralela à linha da CPTM na crista que divide a bacia da Billings da Bacia da Guarapiranga. Do lado esquerdo está

65. Inaugurada em 1985, a estação é um projeto do arquiteto Walter Toscano em colaboração com Odiléa Setti e Massayoshi Kamimura. 
o Jardim Império, bairro de classe média, e do lado direito, do outro lado da linha férrea, está o autódromo Interlagos e Cidade Dutra $(22 \mathrm{Km})$.

A avenida de três pistas e canteiro central segue em topografia regular, com pequenos aclives e declives, por 2 quilômetros, sempre paralela aos trens. A essa altura, a linha imaginária de delimitação da área de proteção aos mananciais já foi cruzada e o que se vê em volta é um bairro bem urbanizado, estruturado, de média densidade.

Há uma grande ruptura no padrão de urbanização a poucos metros da estação autódromo: a avenida larga, projetada com inclinações suaves e canteiros centrais e laterais transforma-se na "Avenida" Matias Beck: duas pistas estreitas que mal se acomodam no relevo acentuadamente inclinado, o casario de bloco cerâmico sem revestimento invade a pista em alguns trechos em que não há calçadas, vê-se a delimitação entre o público e o privado apenas no meio fio, onde está a porta de algumas casas. Aparentemente, a área pública entre a linha de trem e a via de automóveis foi ocupada por favelas que hoje encontram-se consolidadas. Pela via férrea se vê um grande corte de terra, com um talude de vários níveis permitindo a passagem dos trens nesse trecho do território.

Desse ponto até as estações seguintes, Primavera-Interlagos ( $23 \mathrm{Km}$ ) e estação Grajaú (24km), permanece-se próximo a linha do divisor de águas entre as bacias, com relevo relativamente regular, com inclinações medianas, que permitem a linha do trem atravessar o relevo apenas com cortes e aterros. Logo após a elevação até a estação Primavera-Interlagos, há uma baixada em direção ao Hospital do Grajaú, alguns metros adiante se vê a estação terminal Grajaú e acesso à Avenida Belmira Marin ${ }^{66}$, antiga estrada do Bororé. É nesse momento que o percurso descola-se da via férrea.

O próximo trecho inicia-se a partir do terminal, onde a Belmira Marin encontra-se na cota 760 e está inserida na bacia de contribuição da Guarapiranga.

A antiga estrada do Bororé, única via estruturadora da península do Cocaia, parte da cota 760 e se eleva até a cota 818 em direção ao Parque São José, quando encontra a antiga estrada do Cocaia, atual Avenida Antonio Carlos Benjamin dos Santos. Neste trecho predomina o comércio variado, alternando bancos, comércio varejista variado e cadeias de "fast-food". As ruas perpendiculares dão acesso a bairros de padrão médio onde predominam lotes de 6 metros de frente, ruas e calçadas de padrões regulares e relativamente bem urbanizados, com presença de áreas livres e grandes equipamentos públicos, como o centro cultural Grajaú e o $27^{\circ} \mathrm{BPM}$ (Batalhão de Polícia Militar Metropolitano).

Quando se atinge a cota 818 no Parque São José/Jardim Planalto $(27 \mathrm{Km})$ e entra-se na bacia da Billings, a paisagem muda radicalmente. O que se vê a partir do cruzamento entre as duas Avenidas é um "mar" de casas de dois pavimentos ou mais, sem reboco, mimetizando o relevo da microbacia do Ribeirão Cocaia. Com exceção da várzea, na cota 747, a bacia encontra-se totalmente urbanizada.

Segue-se pela Belmira Marin desde a cota 818 até a cota 747. O uso do solo, até então predominantemente comercial, é entremeado por residenciais de baixo padrão, com calçadas bastante estreitas. É difícil identificar se os lotes tem dimensões variadas ou se no mesmo lote estão mais de unidade

66. Estrada do Bororé teve seu nome alterado em 1983 quando o ex-presidente da CBF José Maria Marin, personagem envolvido em uma séria de escândalos de corrupção ao longo de sua vida, era então governador biônico e alterou o nome da estrada em homenagem a sua mãe, Dona Belmira Marin. 


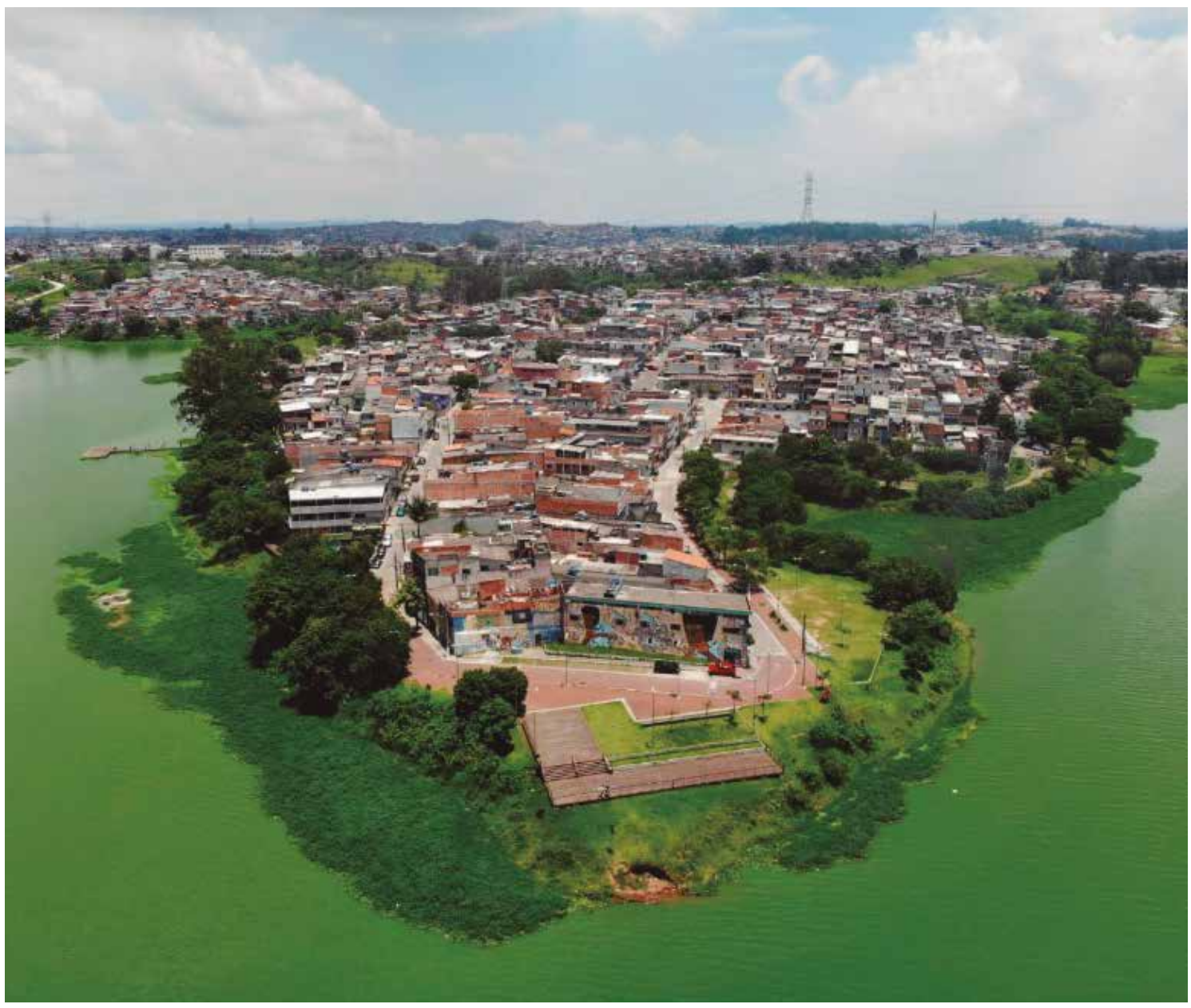

[42] Vôo drone

Michel Gubeissi e Carolina Gimenez, 2018 
habitacional. Na descida íngreme até a várzea, é possivel identificar algumas vielas transversais à avenida onde a urbanização é bastante precária e o esgoto segue diretamente para a rua.

Após a várzea, atravessa-se a elevação do Parque Cocaia até a cota 786, com o conjunto habitacional Faria Lima ao lado direito $(28 \mathrm{Km})$, passando novamente por outra baixada no córrego contribuinte ao Cocaia, para então chegar ao divisor de águas entre o Cocaia e o Ribeirão Varginha na altura da Linha de alta tensão por onde se acessa a península do Cocaia na altura da estrada do Barro Branco, atual Avenida Carlos Barbosa Santos (30 Km).

A península é acessada pela cota 807 pela Rua Pedro Escobar, implantada paralela a linha de alta tensão. Embora não haja sinalização para o Parque Linear, o GPS (Global Positioning System, ou "Sistema de Posicionamento Global") informa onde deve ser feita a conversão. É importante ter atenção nesse momento, pois saindo das vias estruturadoras, é fácil se perder no bairro, onde não há espaços livres ou marcos urbanos significativos e predominam residências de médio a baixo padrão bastante homogêneas.

Vê-se uma placa indicando "Céu Navegantes" em frente, é a hora de fazer a conversão à direita na rua Cisne Azul (31 Km). Passa-se o "portal "da linha de alta tensão, único momento em que a ocupação urbana por residências deixa de existir e se veem alguns cercadinhos sem edificações onde aparentemente se produzem e se armazenam plantas e verduras. Embaixo da linha, na rua que acessa o Parque Residencial dos Lagos, há uma espécie de feira livre onde se vende de tudo: bicicletas, televisores, pneus, eletrodomésticos e etc. Chega-se a cota 787 na rua Andorinhas Brasileiras que desce até a cota 750, de onde se vê o mirante do Parque Linear. Chegando no Mirante (32 Km), a sensação é de estar em frente ao mar, tamanha a ventania, dimensão da represa e a cor da água.

Ao lado do mar de casas autoconstruídas que caracteriza o bairro, está o mar da Billings.

\section{História, memórias e Paisagem}

O Parque Linear situa-se no Complexo Cantinho do Céu ${ }^{67}$, que abrange os bairros Jd. das Gaivotas, Lago Azul e Cantinho do Céu. Localiza-se ao sul do Município de São Paulo no Distrito do Grajaú. A urbanização do Distrito, vista através de fotos aéreas históricas, está associada a um momento em que chácaras e parcelamentos maiores de terra mudam de padrão com o processo desmembramento em lotes populares.

Em imagem aérea de 1972, anterior a Lei de Proteção aos Mananciais (LPM), observa-se, conjuntamente com a construção da COHAB Faria Lima e Sesc Interlagos, o vetor de crescimento em direção a península do Cocaia, com a formação dos bairros Parque Cocaia e Jardim Eliana e o arruamento do Parque Residencial Cocaia. Essa tendência irá se consolidar nos anos seguintes, a despeito da promulgação das leis de proteção aos mananciais, conforme alguns apontamentos feitos no capítulo 1 da dissertação em que se ilustrou os processos mais amplos que levaram a ocupação urbana das porções a sul da metrópole.

Ao observa a série de imagens aéreas, a linha de alta tensão parece ter atuado como barreira à ocupação integral da península até o fim da década de 1980. A partir de então, num período curto e com um padrão de loteamento bastante irregular e

67. Termo adotado por MATSUNAGA (2015) que corresponde a terminologia técnica adotada pela municipalidade de São Paulo e EMAE. 


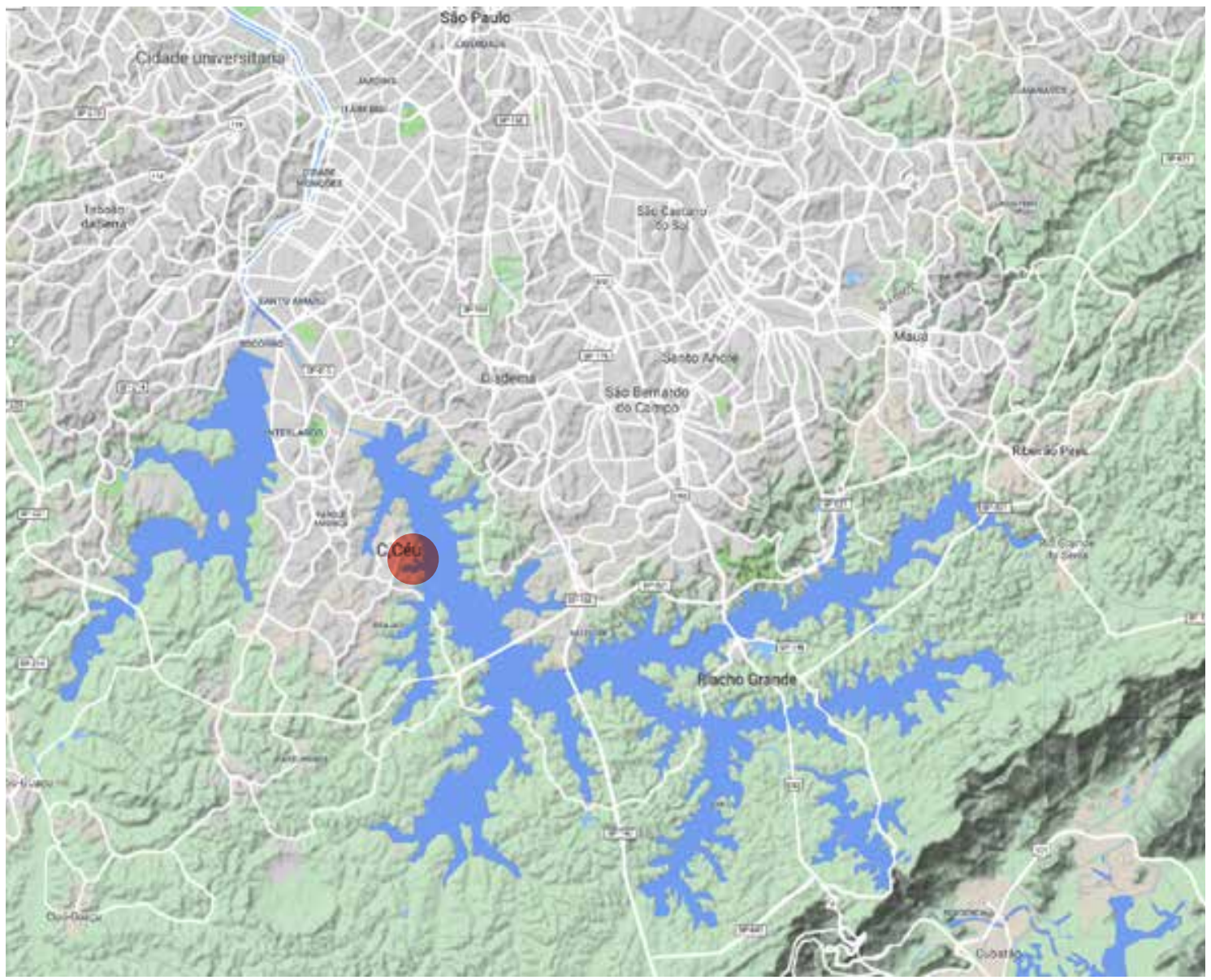

(1) $1 \mathrm{Km} \smile 5 \mathrm{Km}$

\section{Cantinho do Céu}

Mancha urbana

Principais eixos viários

Rios e Represas

Área não urbanizada

[43] Localização do Complexo Cantinho do Céu, onde implantou-se o Parque Linear. Sem escala

Base cartográfica: Google Earth (2018) 

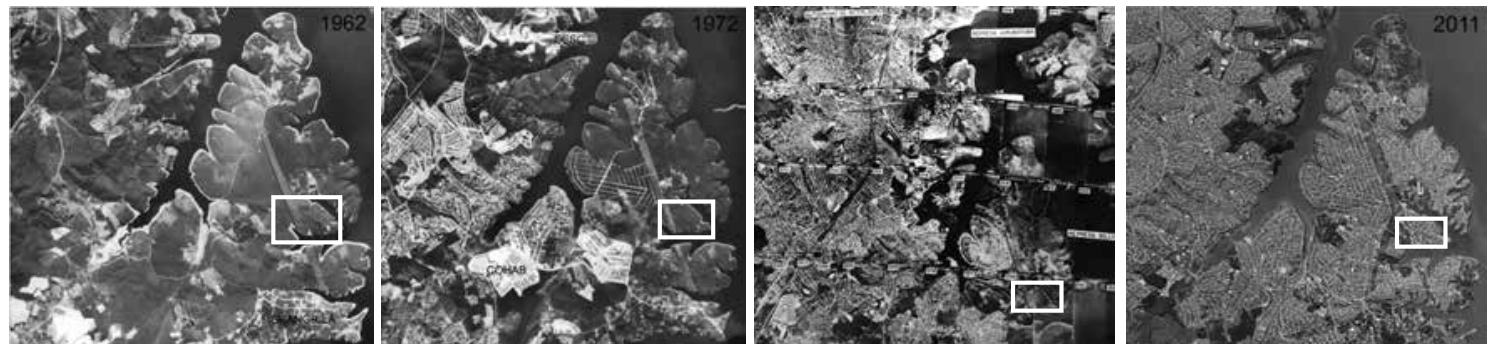

[44] Localização do Parque Linear

Cantinho do Céu.

Sem escala. 1962/1972/1989/1994

Matsunaga (2015)

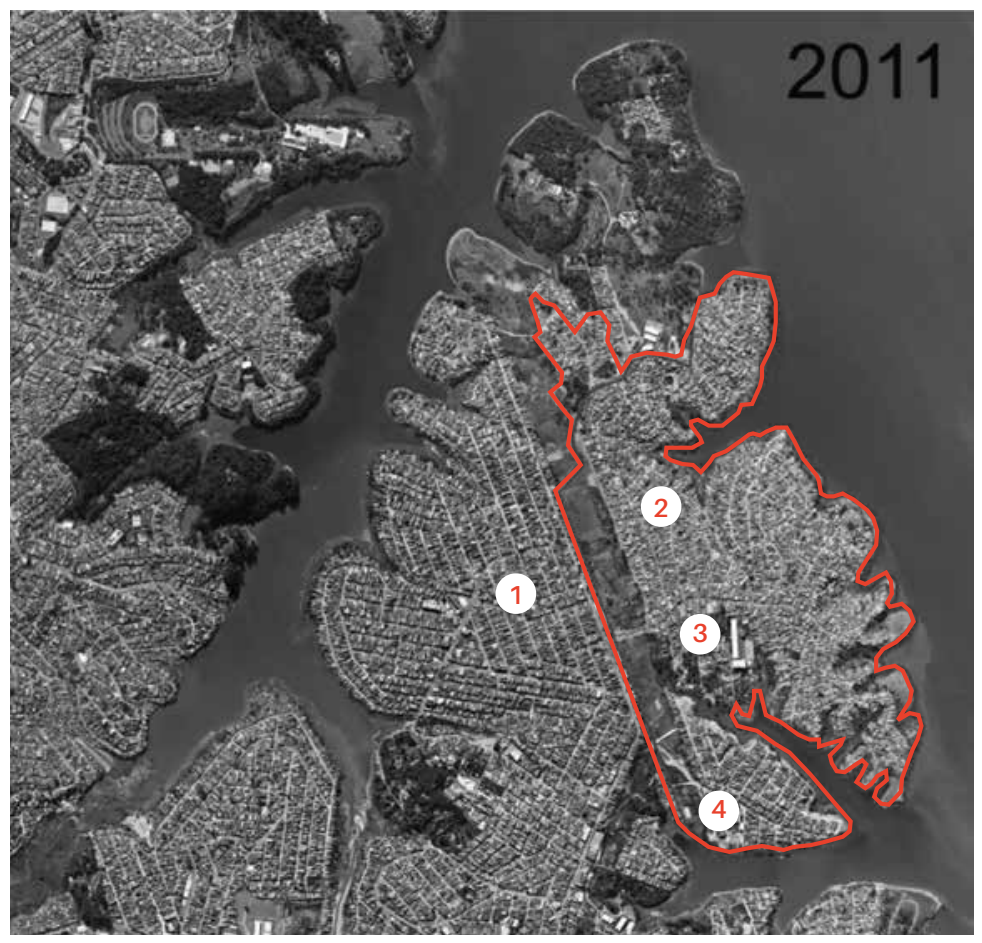

[45] Foto aéra com delimitação da área

correspondente ao complexo Cantinho do Céu.

Fonte: cesad fau-usp

1. Parque Residencial Cocaia

2. Gaivotas

3. Cantinho do Céu

4.Residencial dos Lagos ou Lago Azul

Delimitação do complexo Cantinho do Céu 


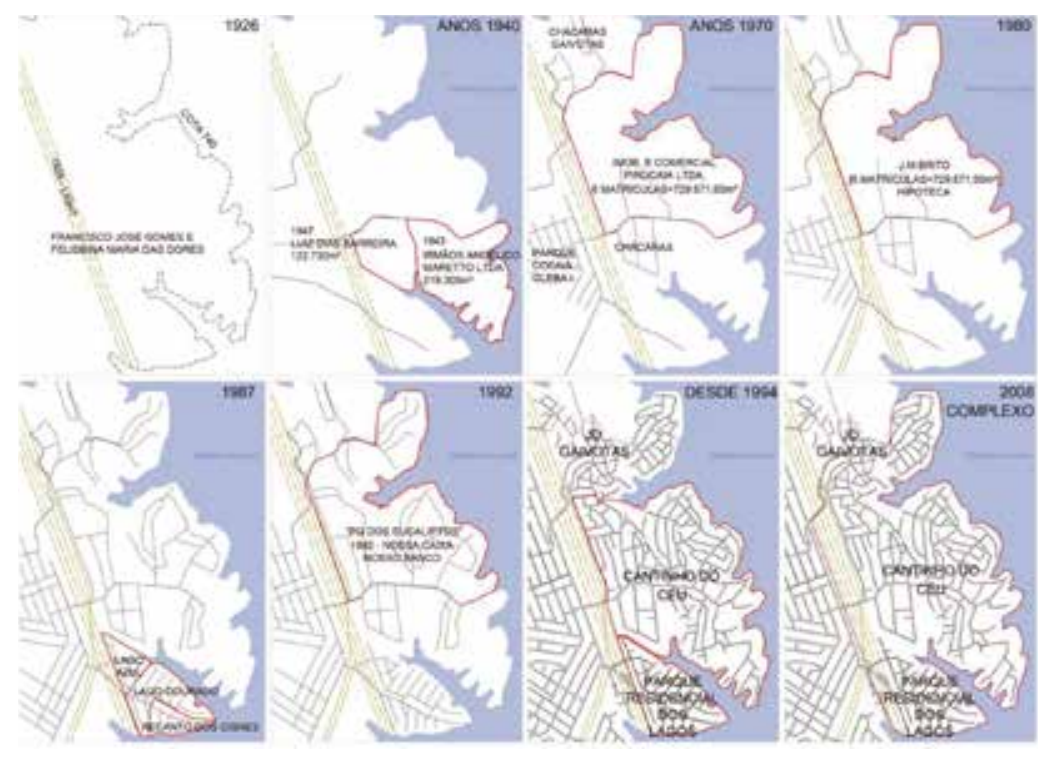

precário, facilmente identificável pelas características do sistema viário, a urbanização avança até as margens à leste como se vê na imagem aérea da década seguinte, realizada em 1994. Essa forma de urbanização pode ser vista na porção mais a norte do complexo, que diferentemente do Parque residencial dos Lagos (à sul) e em contraste ao Parque Residencial Cocaia (ao lado esquerdo do "linhão"), possui ruas sinuosas, lotes irregulares, algumas áreas livres, mas já com arruamento, indicando que o processo de consolidação ainda está em curso.

A mudança de propriedade das terras e alterações nas dimensões das glebas ocorre formalmente ao longo de um período que se inicia com a desapropriação pela Light para fins de represamento do Rio Grande, até períodos a década de 80. A partir da década de 80 altera-se o uso e a densidade das propriedades, conforme relata Matsunaga (2015):

"(...) As primeiras transcrições e registros cartorários presentes no processo judicial informam os proprietários das glebas, cujas respectivas áreas aqui sugeridas, formariam os bairros do Complexo, que pertenciam nesse momento a Francisco José
Gomes e sua esposa, Felisbiana Maria das Dores. A transferência a Light diz respeito a uma parte da gleba original, cabendo esta parte a área de $179.534 m^{2}$ ou 7.419 alqueires (...)

No entanto, a conjugação aqui realizada é suficiente para demonstrar o processo de transformação do território: passando de grandes glebas, denominadas inicialmente sítios (Sítio dos Rodrigues, Sitio Batuira), passando por chácaras, como foi o caso da gleba adquirida por Luiz Dias Barreira e esposa, Elisa Demarebi Barreira, que adquiriram 5 alqueires e $2730 m^{2}$ em 1947, e que nos anos 1970 foi subdivida em chácaras. Grande parte dessas glebas foi destinada a silvicultura até o final do anos 1980, quando estas começam então a serem parceladas clandestinamente para uso residencial, alterando a densidade de ocupação" pp.59-60

O processo descrito por Melissa em seus mapas e texto comparece também na descrição de Paula Santoro (2008) que com base em entrevistas e fontes secundárias elabora histórico singular da ocupação, chegando a conclusão que ali se configurou uma "mistura de processos" em que comparecem 
diversos atores e diversas formas de loteamento:

"(...) as histórias contadas mostram que o local parece mais uma mistura desses processos: há proprietários de chácaras que ainda hoje moram lá em grandes lotes, arborizados; há loteadores clandestinos aparentemente desconectados com proprietários; e há proprietários que procuraram imobiliárias clandestinas para viabilizar um parcelamento que futuramente seria regularizado lo que parece lógico, considerando que não há processos de reintegração de posse registrados nessas áreas, não há oposição por parte dos proprietários à ocupação). E também esses processos foram se misturando no tempo: inicialmente uma ocupação pouco organizada de iniciativa de "forasteiros", posteriormente os próprios chacareiros abandonam suas propriedades, deixando-as serem ocupadas, e proprietários que resistiram ao processo e até hoje moram lá" (SANTORO, 2008, p. 8)

Nos relatos de moradores, há correspondência entre esse processo de transformação de chácaras em lotes populares em mais de um momento do crescimento do bairro. Ferruge conta que primeiro seus pais compraram um terreno na década de 1990 e 20 anos depois foi a vez de ele comprar o seu:

FERRUGE: Quando meus pais vieram para cá era uma chácara (em 1990), e é muito parecido com a minha história atual, a dona da chácara se chamava dona Denise e era uma chácara muito grande, ela resolveu dividir a chácara em quatro terrenos, meu pai resolveu comprar um terreno, ela tinha documento da área e ele comprou o terreno e ela fez um contrato com ele de gaveta. A mesma coisa aconteceu comigo depois (2008), eu comprei um terreno que era uma chácara, uma das últimas chácaras do bairro e quem vendeu era uma senhora muito antiga no bairro, ela separou quatro terrenos, um para ela, outro para o filho dela, outro para o cunhado e eu, eu comprei o terreno e fiz minha casa. Mas assim, tem de tudo aqui, são muitos processos de formação do bairro.

Esse processo também pode ser percebido por moradores de outros bairros próximos, como é o caso de Enivo, que morava no Jardim Eliana, que fica no topo da península, antes da passagem pelo "linhão da Eletropaulo". No período em que morava no Grajaú, Enivo relata como acompanhou o processo de mudança da paisagem:

"É, são 28 anos atrás... Não existia nada. Hoje tem banco, tem tudo lá, mercado, Marabraz, Casas Bahia... e era a vista que eu tinha da minha janela, que era uma floresta. Então eu acompanhei esse processo de desmatamento e crescimento de um bairro. Essa é uma memória que eu tenho de infância... da minha laje, que era em uma parte muito alta, dava para ver até o Pico do Jaraguá. Que fica atrás do Cocaia. Eu vi toda essa migração: mata, barracos, casinhas, casões e uma cidade hoje em dia".

Busca-se aqui apontar para o fato que a constituição da paisagem construída no entorno do Parque Linear se fez de maneira acelerada e com grande descompasso entre a velocidade de construção de casas e implantação de infraestrutura urbana. Sabese, pelas imagens aéreas e relato de moradores que num período de aproximadamente 30 anos os ares rurais do complexo se transformaram radicalmente levando-o a densidade de grandes centros urbanos com 212 hab/ha ${ }^{68}$. Essa velocidade de crescimento

68. A região abriga 9.789 famílias numa área com $1.543 .761 \mathrm{~m}^{2}$, segundo o projeto de regularização da Prefeitura Municipal de São Paulo, ocupando parte do Programa Mananciais. Utilizou-se para o 


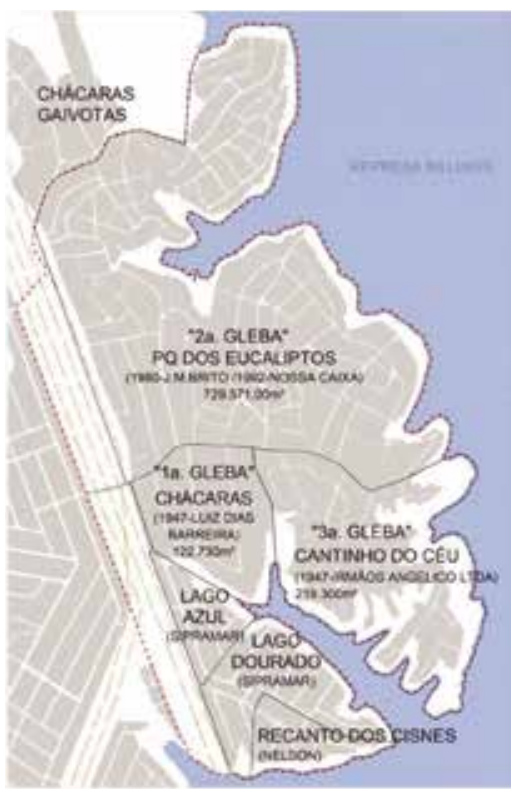

[47] Delimitação aproximada das glebas e domínios fundiários.

Fonte: Matsunaga (2015) p. 75 não foi acompanhada pelo investimento do Estado em serviços públicos, sendo comum, no relato dos moradores, a precariedade ser presença cotidiana:

"CAMILA: Aqui é um lugar que eu moro desde criança, é um lugar maravilhoso. Se você soubesse como eram essas ruas aqui de barro, antigamente o meu pai tinha que por sacolinha de lixo no pé para poder subir, porque trabalhava em hospital, para poder subir até a avenida para pegar um ônibus".

"FERRUGE: O pessoal na época (década de 80) quando vinha pescar tinha como referência o seu Pierre Mambeli, pai do Sandro, que morava na chácara Cantinho do Céu. Ai o pessoal começou a chamar a região do mesmo nome. A região é muito rica, apesar das dificuldades. A água antes vinha de outras regiões que puxávamos com mangueiras. Nem esgoto, canalização, não tinha nada. O povo identificava quem morava aqui pelo barro nos pés, porque não tinha asfalto, não tinha nada. A região não tinha energia, água potável, mas foi crescendo

cálculo de densidade 3.34 pessoas por família, média fornecida pelo IBGE para o ano de 2010. com a ajuda do povo da comunidade, foi crescendo, se fortalecendo"69

Em julho de 1994 a Promotoria recebeu uma carta anônima de Moradores da região da Billings, autodenominados "proprietários legítimos" que expunha em forma de denúncia os processos que aconteciam nesta porção da península, dando início a um processo que culminará na Ação Civil Pública em 1997. Embora o crescimento e adensamento do bairro tenha ocorrido de forma diversa e com diferentes atores, ou uma "mistura de processos" como apontou Santoro (2008), é através da reinvindicação ao direito de propriedade de alguns que Ministério Público (MP) acolhe a demanda por intervenção na área.

O fato do projeto de urbanização do Cantinho do Céu não ter partido de reivindicações populares ou de pressão por parte dos moradores por regularização e sim através do MP de São Paulo, e a Justiça, com a retomada da questão em 2002

69. em depoimento a Simone Polli (2010) p. 209.

70. Ver carta na íntegra em MATSUNAGA (2015) Anexo B, p. 211. 
sugere, segundo Polli (2010) um padrão que denomina de "Cidadania tutelada", e expressa um tipo de cidadania que a direita (elite econômica e política) cultiva ou suporta, a saber, aquela que se tem por dádiva ou concessão de cima. Para a autora, o caso do Cantinho do Céu poderia se enquadrar nessa categoria. A autora reconhece a importância e o papel desempenhado pelo Ministério Público nessas ações ao articular as instituições e exigir a regularização fundiária da área, mas é crítica ao apontar uma possível transferência de responsabilidades na resolução de problemas:

"entende-se por cidadania tutelada o fato de se transferir a este órgão a resolução de problemas, sem a participação direta da população nas etapas do processo de regularização, na concepção dos projetos, precarizando o amadurecimento político e social desses grupos". p. 219

A autora afirma também que a regularização urbanística do Complexo Cantinho do Céu é um típico "projeto piloto"71, em que se observam grandes investimentos em determinadas áreas em detrimento das intervenções no conjunto das ocupações irregulares em mananciais. Desse modo, os benefícios sociais são distribuídos de forma desigual entre os moradores da área de manancial.

Do ponto de vista aqui estudado, no entanto, é difícil de fazer essa afirmação. Pelos resultados observados no uso e ocupação do Parque Linear observa-se uma apropriação abrangente pelos moradores vizinhos ao parque, mas também de muitos moradores dos bairros do entorno. Como se verá mais adiante, a presença de moradores de diversas

71. Ver <https://www.observatorioderemocoes.fau.usp.br/wp-con tent/uploads/2015/06/Observatorio_REMOCOES.pdf> acesso em 23.04.2019. partes do Grajaú e de outras regiōes da cidade revela que os benefícios extrapolam as barreiras do Cantinho do Céu. A despeito dos problemas apontados por Polli, há que considerar o componente simbólico de retomar uma parte das margens da represa para a cidade.

O processo que culminou na urbanização de parte do complexo Cantinho do Céu alterou a forma como o próprio Ministério Público vinha se posicionando em relação ao direito à moradia em áreas de mananciais, o que pode ser visto como um relativo avanço em direção a uma jurisprudência em que se leve com consideração os processos reais de crescimento da cidade. Alguns entrevistados ${ }^{72}$ apontam para um certo "descolamento" da realidade no momento inicial de discussão de soluções para o Cantinho do Céu em relação a postura do MP. Elisabete França relata que havia uma ação para tirar "dez mil famílias do dia para noite" e que na época o Ministério Público estava muito atrasado e em constante briga com a SEHAB. Foram feitas inúmeras negociações para não se desconfigurar o bairro inteiro em nome de manter uma linha "imaginária" não edificada de 50 metros a partir da cota de alagamento da represa, sendo em alguns casos pactuado faixas menores para diminuir o número de remoções. Para a arquiteta haveria ainda naquele momento um certo descolamento do Ministério Público em relação à realidade da ocupação.

Pode-se dizer que do prisma fundiário, é de fato um desafio a resolução de conflitos de uma "urbanização à paulista" em área de mananciais, onde agem na compra e venda de imóveis desde "proprietários legítimos", que muitas vezes são os mesmos que desmembram lotes de forma irregular, como também imobiliárias informais, crime organi-

\footnotetext{
72. Marcos Boldarini, Melissa Matsunaga e Elisabete França.
} 
zado, milícias e grileiros, sendo muitas vezes difícil rastrear os caminhos por quais passam os títulos de propriedade, que muitas vezes são negociadas no mercado informal e que portanto dificilmente tem os registros em suas matrículas. Nesse ambiente de "confusão" patrimonial, é louvável que se cheguem em soluções que consigam transcender a questão da propriedade da terra, para que prevaleça o direito a moradia e cidadania daqueles que ali residem, razão pela qual a questão fundiária ainda está em aberto nas áreas onde já houve a urbanização, como aponta Elisabete França:

CAROLINA Como ficou a questão fundiária? ELISABETE FRANÇA: Lá é bastante complexo. CAROLINA: E me parece que não está resolvido até hoje, correto?

ELISABETE FRANÇA: Não está e não será resolvido tão rapidamente. Porque uma parte da área é particular, então teria que falar com o dono.

CAROLINA: Uma parte onde foi implantada o parque ou urbanização?

ELISABETE FRANÇA: Urbanização. O parque éna área da $E M A E$.

CAROLINA: E COMO a EMAE tratou?

ELISABETE FRANÇA: O parque já é parque, é só cuidar. O problema é parte em que teve a urbanização ... isso é complicado, porque tem parte que é pública, tem parte que é privada, a gente tinha entrado em contato com o dono, ele queria recuperar a área. Levamos ele lá e ele falou (em tom irônico). E tem instrumentos onde o morador pode pagar para o proprietário, iríamos começar a trabalhar nisso, mas depois mudou de gestão e não houve continuidade.
Por outro lado, é preciso afirmar que esse modelo de urbanização, "espontânea"73 está longe de ser um modelo a ser reproduzido. É um tipo de urbanização carente de recursos públicos e geram questões fundiárias quase insolúveis. Os loteamentos são implantados com baixo custo para o loteador, gerando taxas altas de lucro para o mesmo e prejuízos enormes ao Estado e sociedade, que arcam com todos os custos de urbanização. Nesse sentido, a urbanização de áreas precárias vem após à ocupação do solo, e não antecedendo, constituindo-se como medida paliativa frente ao problema de acesso formal à terra pelas classes menos favorecidas. Não obstante, o "plano piloto" como preconizado por Simone Polli é um marco positivo para outras intervenções que resgatem para a cidade a orla da represa.

O que se observa atualmente é que as edificações no Complexo configuram, em sua maioria, o elemento caracterizador da paisagem ao lado da represa, que se revela ora em mirantes que se configuraram pontualmente pela topografia do sítio urbano, ora nas margens, quando é possivel ter a apreensão da enorme dimensão que a represa ocupa no território. O Parque faz justamente essa mediação entre o interior construído e o enorme espelho d'água.

\section{Projeto de urbanização}

A Ação Civil Pública (ACP) referia-se ao Cantinho do Céu como a "Expressão viva do inferno de Dante", na expressão do Promotor Carlos Alberto Amin filho, autor da ACP. Esta ação, movida pela Promotoria de Justiça de Habitação e Urbanismo da Capital

73. Terminologia usada por Ricardo Toledo em entrevista a autora em janeiro de 2019 para se referir as ocupaçōes urbanas em área de manancial. 

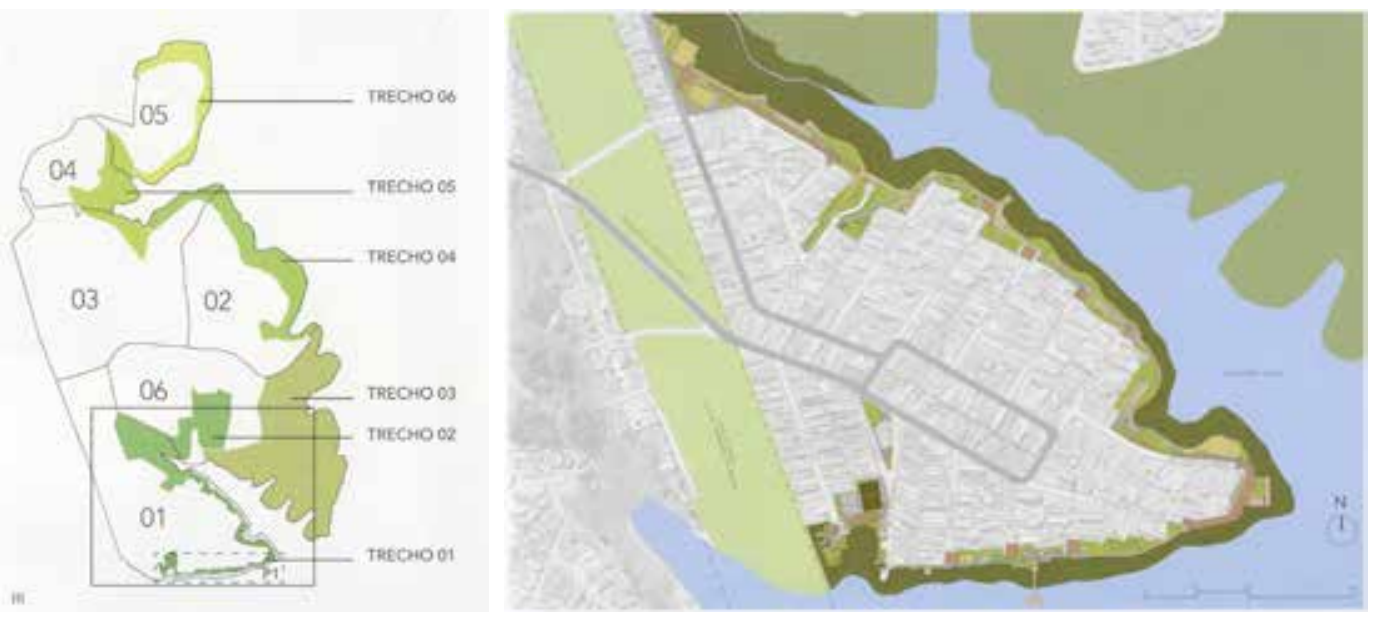

[48 e 49] Planta Geral dos trechos de projeto de urbanização. Implantação do Parque no trecho 1 FRANÇA, BARDA (2012)

contra a Prefeitura, Governo do Estado e os ex-administradores regionais da Capela do Socorro da gestão Erundina (1989-1992) e da gestão Maluf (1993-1996) ${ }^{74}$, resulta de processo investigativo que envolveu não apenas o Cantinho do Céu, mas outros bairros que estavam passando pelo mesmo processo de ocupação ilegal. Mas foi durante o segundo mandato de Gilberto Kassab (2009-2012) eleito pelo DEM, que se encontrou a solução institucional, dentro do Programa Mananciais, para que houvesse uma mediação e não demolição total do bairro, inicialmente prevista pela ACP.

Para Marcos Boldarini, o projeto do Cantinho do céu tem uma equação muito singular justamente por ter tido esse início "judicializado", em que se coloca Prefeitura do Município de São Paulo e Sabesp como rés em um mesmo processo e a ordem expedida do Juiz é de desfazimento do assentamento. O projeto do Parque em si não havia nem sido previsto no projeto básico, conforme relata Marcos:

74. A ação foi movida contra Prefeitura e Estado, em conjunto com os administradores regionais.
"A ordem do Juiz foi: "Vamos desfazer o assentamento". Então, 1,5 milhão $m^{2}$ tinha de ser desocupado, 10 mil familias tinham de sair dali. Tudo bem, retiramos todo mundo dali, e para onde as pessoas vão? Mesmo que tivéssemos fôlego para uma ação como essa, bancando do ponto de vista econômico e social, o que faríamos com todo o entulho que restaria ali? Então, a prefeitura junto com o Ministério Público e a Sabesp começaram a desenvolver um projeto para a área, que foi o projeto básico usado na licitação de obras, a partir de uma licença especial. O escritório entra no trabalho em 2008 mais ou menos, com esse projeto básico e a incumbência de fazer as revisões necessárias para que as coisas caminhassem; todos entendiam que um processo como aquele era "superdinâmico" e pressupunha adequações e revisões. Como o projeto básico não tinha os sistemas de lazer e as áreas livres desenhadas, ficamos também com a incumbência de fazer toda a área verde".

O projeto previa a construção de um parque linear em 6 trechos, dos quais apenas o primeiro 
foi executado. A realização dos trechos permitiria que uma parte significativa da península do Cocaia pudesse ter seus territórios integrados, totalizando $7 \mathrm{~km}$ de parque linear.

Tratando-se de um dos bairros mais carentes da cidade de São Paulo, o projeto foi desenvolvido a partir de diretrizes formuladas pela Secretaria Municipal de Habitação (SEHAB) em conjunto com a Promotoria Pública, como uma resposta frente a determinação de desocupação da área.

O projeto, segundo Marcos, formulou hipóteses de intervenção que almejavam suprir déficits de infraestrutura, qualificar e integrar o assentamento à cidade compatibilizando as diversas disciplinas envolvidas, além de questões fundiárias. A interlocução entre projetistas e comunidade se deu através de lideranças comunitárias, conforme relata Melissa Matsunaga:

"Houve uma interlocução com a Dona Vera, que era naquele momento uma liderança muito forte, tinha representatividade, tínhamos uma conexão direta com ela. Chegamos a fazer no canteiro de obras uma apresentação da proposta geral do parque num sábado de manhã, mas foi muito pouca gente, então se for ver, o canal mesmo de interlocução foi sempre intermediado com a Dona Vera"

A percepção tanto de Melissa Matscunaga como de Marcos Boldarini é de que através de Elisabete França que se criou um ambiente mais favorável para o desenvolvimento de um "projeto piloto". O projeto básico não contemplava o Parque, somente após a contratação da obra que o escritório foi convidado a desenvolver o projeto. Marcos relata:

"Ela (Elisabete França) que bancou esse projeto dentro da prefeitura. Na verdade a coisa fica em pé antes dela, mas tem um momento em que ela vai tomar uma decisão, e por meio das possibilidades legais dos contratos, de gerenciamento, ela chega ao fim de sua atuação pela prefeitura com 40, 45 escritórios de arquitetura trabalhando para a secretaria de habitação, tem desde o Marcos Boldarini até o Marcos Acayaba".

Essa percepção é compartilhada por Melissa, para quem Elisabete chamou para si a responsabilidade de fazer as mediações com órgãos de licenciamento, inclusive para questões de projeto:

"A Bete bancou essa responsabilidade, a gente estava executando, mas tinha alguém que estava por trás dando suporte, em relação aos órgãos licenciadores por exemplo, tinha que ter alguém enfrentando. E eu vejo que essa atitude dela foi muito importante para termos a solução que tivemos lá, de adentrar a represa, por exemplo. Fizemos decks que se projetavam na água, pode parecer muito simples e tal, mas quando vai ver a questão legal isso tudo é muito engessado, muito complicado de se fazer. Então ela foi alguém que bancou essa responsabilidade, puxou para ela"

Por outro lado, Elisabete França vinha, em suas palavras, de uma experiência com os projetos do programa Guarapiranga, que foi uma referência para intervenção no âmbito de microbacias, conforme relata a arquiteta:

"Já tínhamos aprendizados do Programa Guarapiranga, e em 2005 quando eu voltei para a prefeitura, eu tinha passado anteriormente quatro anos trabalhando em projetos com o Banco Mundial, então quando começamos a fazer o plano de habitação, no diagnóstico todo, a gente estabeleceu 
uma unidade territorial de projeto semelhante ao do Programa Guarapiranga, que era sub bacia, então todo o plano de habitação foi em função das unidades territoriais dessas sub bacias, os arquitetos projetavam dentro dessa lógica. No plano foram feitas prioridades e a contagem das casas, assim, o diagnóstico foi feito em cima dessa contagem, que é uma maneira de entender a realidade do local".

De modo geral, todos técnicos aqui entrevistados ${ }^{75}$ tratam a intervenção com bons olhos. Marcos, além de ter conquistado segundo ele uma condição de respeito, alega que essa relação permanece nas consultas posteriores aos trechos em andamento.

Mesmo sendo um projeto simples em termos técnicos/construtivos, com uso de pouca movimentação de terra, arrimos baixos em alvenaria estrutural, é um projeto que traz inovações dentro do universo de materiais e soluções para projetos de áreas públicas, notadamente o uso de madeira e ativação da relação com água.

75. No que tange os questionamentos sobre as formas de financiamento do projeto, a relação com as agências internacionais de financiamento e seus desdobramentos, sugere-se consultar os autores citados na nota 36 , página 45 


\section{Incorporando princípios da Antropologia no olhar do arquiteto}

\section{Etnografia como método de pesquisa em Arquitetura}

A pesquisa de campo partiu de um ponto em que se viu a necessidade de ouvir e entender o ponto de vista do usuário dos espaços que foram eleitos para a pesquisa. Assumindo essa perspectiva e modo de ver o objeto, entendeu-se que adotar princípios da antropologia urbana traria um ganho qualitativo ao trabalho.

Ao se debruçar sobre as fontes humanas, captando seus pontos de vista, o espaço ganha vida. Sem a pretensão de construir "a verdade" sobre o lazer na represa, optou-se por registrar algumas experiências, para revelar o olhar de alguns de seus usuários, como se relacionam com o lugar, como participam politicamente dos espaços. Esse tipo de registro, inserido no campo dos estudos culturais, fornece pistas para que o universo do pesquisado seja partilhado e contrastado com o universo do pesquisador, numa relação de troca onde o resultado pode indicar um novo caminho.

A etnografia urbana permite problematizar o discurso que homogeneíza a experiência na cidade através de imagens como a massificação e despersonalização dos indivíduos nas metrópoles que desconsidera a forma como as pessoas participam efetivamente da cidade no dia a dia. Nesse sentido, as primeiras experiências de campo forneceram um insight importante: enquanto o projeto de pesquisa propunha-se repensar margens e espelho d'água por usos estruturados para o lazer, e questionava a apropriação exclusivamente técnica que se fazia dos mesmos, o campo revelou que haviam múltiplas apropriações desses espaços que estavam fora do discurso dos trabalhos acadêmicos, dos jornais e dos técnicos. Era necessário aproximar-se.

Numa sexta feira ensolarada em março de 2018 enquanto eu observava a represa andando na orla da Prainha, o salva-vidas, percebendo que eu não era do pedaço ${ }^{76}$, se aproximou para entender o que me trazia ali. Contei que era estudante universitária e estava pesquisando o lazer na represa. Enquanto discorria sobre o porquê da água da represa não servir para as pessoas se banharem ou se divertirem, ativi-

76. O termo no jargão popular define um lugar onde as pessoas se conhecem e se reconhecem. Magnani empresta do uso corriqueiro e desenvolve uma categoria analítica para ser empregada no estudo de campo, ver mais adiante. 


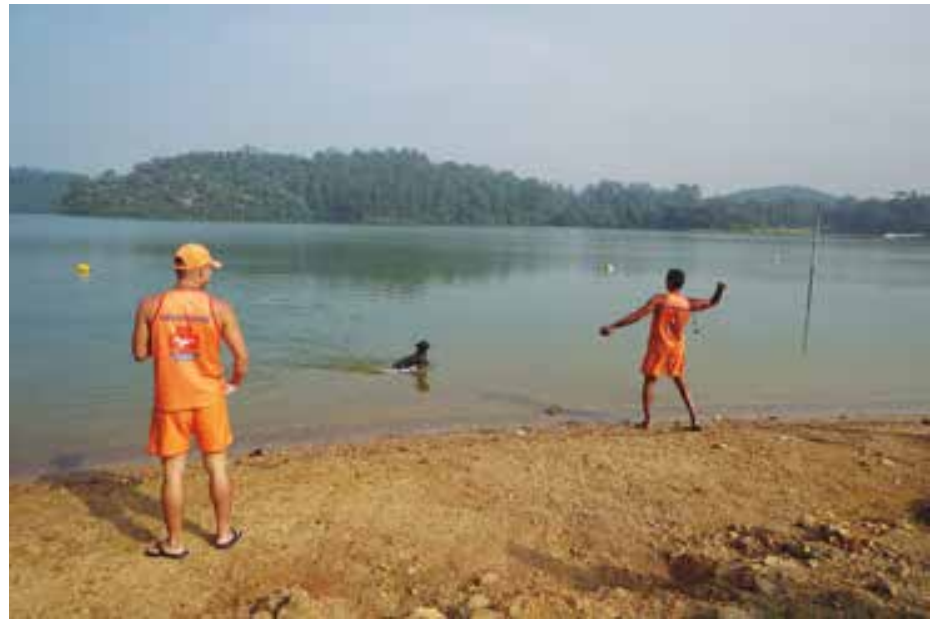

[50] Prainha

Carolina Gimenez, 2018

dades que segundo ele eram proibidas pelo poder público, o salva-vidas brincava com um vira-lata que costumava passar o tempo ali junto aos seus colegas de salvamento. A brincadeira parecia divertir o homem e o cachorro, e como eu demonstrava interesse, o salva-vidas começou a jogar o toco de madeira cada vez mais longe para o cachorro buscar. Investi um pouco naquela conversa perguntando se o cão era o mascote da Prainha, se participava dos salvamentos, quando me deparei com a seguinte resposta: "ele gosta muito de nadar, às vezes me acompanha de manhã cedinho nadando até a outra margem". Naquele dia a água parecia particularmente limpa.

Nadar espontaneamente até a outra margem era, portanto, uma imagem suficientemente forte para desconstruir a ideia de que a água da represa não servia para as pessoas estarem lá. Por outro lado, era um choque saber que alguém se dispunha a nadar tantos metros naquela água "imprópria para banho". Seria apenas uma contradição entre o discurso e a prática? Sabendo-se que o discurso nunca dá conta da realidade que ele representa, mas que pode dar pistas e algumas vezes dentro de uma aparente incoerência ele pode ser entendido como uma via de acesso a uma informação mais preciosa, pareceu-nos que havia ali uma situação a ser explorada.
Até que ponto a pesquisa antropológica, voltada para situações e casos singulares como esse, estaria restrita a descrever aquela ocorrência numa perspectiva da experiência pessoal do salva-vidas, que por "teimosia" nadava todos os dias de manhã na represa, ou se ao contrário, sem abandonar esse nível de observação e análise, essa abordagem permitiria criar condições de inseri-la nos processos mais amplos como uma forma de acessar um melhor entendimento das dinâmicas de uso daquele espaço e sua relação com a paisagem da represa?

Em "Da Periferia ao Centro" (Magnani, 2012) o autor, ao analisar as trajetórias de pesquisa em Antropologia Urbana, propõe que a experiência de campo colabora com esse entendimento ao revelar que o lugar comum do "caos urbano" é insuficiente para estudar as dinâmicas urbanas:

"[...] Ampliou-se o horizonte: é a própria cidade que se expõe, em escala de metrópole. Se "lazer" numa visão correntee limitada não dava conta desse quadro, "tempo livre", por sua vez, precisava ser qualificado, pois abrange desde momentos de simples descanso individual até atividades coletivas altamente elaboradas e dispendiosas de cultivo do corpo, aprimoramento intelectual, busca de espiritualidade, construçãoe 
demarcação de identidades, exercício de cidadania. E se por um lado é no contexto da cidade que essa multiplicidade se manifesta, quando ela é analisada para além das particularidades de cada manifestação, aquela explicação é fácil, inevitável e sempre a mão-o decantado caos urbano- mostra-se redutora e insuficiente. Ao contrário: em vez de uma situação de anomia, fragmentação ou caos, o que se percebia era a existência de regularidades - trajetos plenamente identificáveis, circuitos conhecidos e explorados por seus usuários, manchas de convivência e consumo de determinado produto ou serviço-como porexemplo, porções inteiras de bairros dedicadas a gastronomia italiana ou "a vida noturna, no Bixiga e na Vila Madalena, respectivamente, para citar apenas dois entre os mais conhecidos. [...]" pp.79-80.

Para o autor, no trabalho de campo consegue-se analisar a dinâmica urbana contemporânea sob a perspectiva de quem dá vida a cidade, ou seja, privilegia-se a experiência dos moradores propriamente ditos, em suas redes, sociabilidades, afetos, estilos de vida e deslocamentos. A introdução desses atores e de suas práticas, permite introduzir outros pontos de vista sobre a dinâmica da cidade.

Para tanto, é preciso adotar um ajuste de foco para observar fenômenos urbanos. O termo "de perto e de dentro" representa esse ponto de vista, é utilizado por Magnani (2012) para definir uma forma de análise, própria da antropologia, voltada para a apreciação da dinâmica urbana contemporânea que resgate a experiência dos cidadãos com a cidade. Entendida como uma forma de pensar quando se tem o outro como objeto, pode ser uma ferramenta muito útil para captar aspectos da dinâmica urbana que não seriam notados em "vôo de pássaro".

No campo da arquitetura e urbanismo, esse esforço em compreender a cidade a partir da relação que os cidadãos estabelecem entre espaço e indivíduos que ali estão se dá se inicia com a revisão da doutrina urbanística moderna. Em contraposição a ideia da cidade como máquina que realiza funções produtivas, ou do "rolo compressor" modernista cuja metáfora mais direta é o projeto a partir da tábula rasa, ignorando as camadas de cada lugar, alguns autores procuraram, a partir da década de 1960, retomar o conceito histórico da cidade. Autores como Kevin Lynch (1960) em A imagem da Cidade, Jane Jacobs (1961) em Morte e vida de Grandes Cidades e Aldo Rossi (1966) em A Arquitetura e a Cidade, para citar alguns exemplos, buscaram, cada um a seu modo, introduzir a perspectiva de que as experiências urbanas envolvem elementos importantes como pertencimento, memória e história.

Busca-se aqui contextualizar esse movimento, sucedido por outros autores, como por exemplo a publicação em 1977 de Aprendendo com Las Vegas de Venturi, Brown e Izenour, onde se sugere uma prática em que os arquitetos possam enxergar o existente, não necessariamente fruto do risco do arquiteto, e nesse processo questionar a forma como veem as coisas. Esse procedimento, é importante para criar um espaço dentro da disciplina da arquitetura e do urbanismo para que a diversidade e a pluralidade das cidades contemporâneas sejam reconheciveis e reconhecidas.

O debate é colocado aqui brevemente para ilustrar que dentro do campo disciplinar da Arquitetura e do Urbanismo, há um movimento em reconhecer nos indivíduos e suas práticas elementos importantes tanto na análise de contextos urbanos como para ensejar uma prática profissional que leve em consideração essas questōes, debate que ainda reverbera e é bastante atual. O lazer certamente integra o cotidiano das pessoas em seu aspecto mais "agradável e descontraído". Embora nas condições de vida dos trabalhadores na Grande São Paulo se exija que o 
tempo e energia sejam direcionados majoritariamente para a reprodução da vida, sempre há algum tempo livre para se dedicar à diversão, ainda mais quando ela não requer recursos financeiros. Magnani (1982), dentro de uma perspectiva de pesquisa em antropologia coloca na apresentação de sua tese:

"O lazer - tema deste trabalho-é parte integrante da vida cotidiana e constitui, sem dúvida, o lado mais agradável e descontraído de sua rotina semanal. Exatamente por estas razões é que não está imune a preconceitos quando se trata, não de desfrutá-lo, mas de refletir sobre seu significado. Em primeiro lugar, é considerado irrelevante, enquanto tema de pesquisa: há coisas mais sérias, como o trabalho, a política. Aliás nem mesmo existe: no caso especifico dos trabalhadores, há quem constate que o tempo livre é basicamente utilizado para complementaros magros orçamentos domésticos. Quando existe, ressente-se da falta de espaço, equipamentos, ou então está irremediavelmente contaminado pelos "mass-media", não passando, portanto, de válvula de escape e alienação" p. 3

É no lazer que se expressam as possibilidades de criação dos indivíduos, momento no qual eles fazem as escolhas de forma livre, ou seja, não estão respondendo a obrigações do trabalho, e dessa forma o lazer pode ser tomado como ponto de partida para compreender alguns aspectos da vida cotidiana, não totalmente imune a ideologias de classe, mas certamente com mais significados que uma explicação totalizante como essa poderia dar.

Os dois estudos de caso presentes nessa dissertação focam o lazer que é realizado no espaço público, lugar dos encontros e tensionamentos. Talvez um pouco mais distante da ação direta da ideologia transmitida pelo "mass media", a paisagem da represa, aqui entendida como uma resultante entre processos sociais e naturais que ali ocorrem e que estão sempre em transformação, é o elemento agregador que "convida" as pessoas a passarem o tempo livre ali. É, como aparecerá na fala de muitos, o lugar onde se sentem bem, livres, seguras e em paz, e, ao mesmo tempo, o lugar da aventura e do perigo.

O princípio que norteou o trabalho de campo foi o de fazer uma observação atenta para identificar elementos que a priori não faziam sentido, mas que depois, em seu conjunto, constituíram-se uma versão sobre o lazer na represa. Mais que observação, buscou-se adotar uma postura onde as práticas de lazer fossem observadas de perto, com atenção, para entender o significado para aqueles que a praticam e habilitar a capacidade de descrevê-las de forma mais densa.

Como critério metodológico buscamos nos orientar pela família de categorias proposta por Magnani (1982, 2012) para observar as práticas de lazer no espaço. Seguem abaixo descritas.

Pedaço: termo emprestado do jargão popular, o autor propõe um uso analítico para o mesmo: é o lugar dos encontros entre pares conhecidos. Para o autor, o núcleo do pedaço apresenta um contorno nítido, mas bordas fluídas, e designa um espaço intermediário entre o privado (a casa) e o público, onde se desenvolve uma sociabilidade básica, ampliada em relação à família, porém mais permanente e densa que as relações fora do "pedaço".

As pessoas que não fazem parte do pedaço, podem se sentir receosas, temendo o conflito, pois a hostilidade é latente e o pedaço do outro é aquela parte desconhecida do mapa, onde está o perigo. Essa descrição se encaixa perfeitamente aos dias que antecederam meu ritual de entrada no pedaço do Parque linear. Até o meu encontro com Ferruge no Cantinho do Céu, eu tinha a sensação que eu seria uma 'estrangeira' 
ali, e qualquer coisa poderia me colocar em risco. A sensação foi desfeita no dia que conheci pessoalmente Ferruge durante a oficina de marcenaria: fizemos uma troca em que ele me apresentou o pedaço, ou "quebrada" em suas palavras, e eu intermediei a doação de algumas vigas de madeira para a oficina de marcenaria. Após esse dia eu iria inúmeras vezes citar o nome dele para estabelecer novas relações no Parque.

"São dois elementos básicos constitutivos do pedaço: um componente de ordem espacial, a que corresponde uma determinada rede de relações sociais. Alguns pontos de referência delimitam seu núcleo: o telefone público, a padaria, alguns bares e casas de comércio, o ponto do "búzio"(ônibus), o terreiro e o templo, o campo de futebol e algum salão de baile. (...)No núcleo do pedaço, enfim, estão localizados alguns serviços básicos - locomoção, informação, culto, entretenimento - que fazer dele ponto de encontro e passagem obrigatórios. Não basta, contudo, morar perto ou frequentar com certa assiduidade esses lugares: para ser do pedaço é preciso estar situado numa particular rede de relações que combina laços de parentesco, vizinhança e procedência(...) Magnani, 1982, pp. 206-207

Mancha: É o lugar de reunião de pessoas com determinado gosto cultural, mas que não se conhecem, dando lugar a encontros imprevistos. A mancha é mais generosa e abrangente e se compõe de equipamentos culturais ou comerciais que concorrem entre si ou se complementam, configurando certa estabilidade e visibilidade na paisagem. Tanto do ponto de vista dos acessos, da circulação como das edificações, caracteriza-se por um continuum tal qual a rota do peixe na Prainha, que é composta tanto por restaurantes e quiosques com especialidade em pescado, como lojas de pesca e produtos para esportes náuticos e afins.

Enquanto no pedaço se procuram seus pares, a mancha dá lugar a encontros imprevistos e combinações variadas. Esses conceitos não são estanques e há que se fazer a ressalva, segundo o autor, de que a cidade não é um aglomerado de pontos excludentes entre pedaços e manchas, até porque dentro de cada mancha as pessoas costumam se dirigir aos seus pedaços seguindo determinada lógica, configurando o que Magnani irá denominar trajetos, ou seja, os fluxos recorrentes no espaço mais abrangente da cidade, reconhecíveis em suas regularidades:

"a ideia de trajeto permite pensar tanto uma possibilidade de escolhas no interior das manchas como a abertura dessas manchas e pedaços em direção a outros pontos no espaço urbano e consequentemente, a outras lógicas. Sem essa abertura, corre-se o risco de cair numa perspectiva reificadora, fechada e demasiadamente "comunitária" de pedaço - com códigos de reconhecimento, laços de reciprocidade e relações face a face exclusivistas" p. 96

Circuito: escapa da contiguidade espacial, amplia o espaço da sociabilidade, é o conjunto de pontos conhecidos pelos frequentadores, e pode articular pontos separados da cidade. O circuito é vivo porque depende dos trajetos dos atores. Nesse sentido, o Parque Linear Cantinho do Céu pode fazer parte, em determinados momentos, do circuito de skatistas, como o foi durante o festival Red Bull Amaphiko ${ }^{77}$ ou do circuito dos veganos, durante a feira de encerramento da Unigraja ${ }^{78}$.

77. Verificar adiante na passagem que menciona o festival.

78. Unigraja é resultado da União dos coletivos: Associação esporte clube Vila Real, Agência Cresce, Cooperpac, Casa Ecoativa, Graja na Cena, Imargem, Meninos da Billings, Periferia em Movimento, Nóis por Nóis e Salve Selva. 
Essas categorias foram apresentadas como apoio para constituir e interpretar o material colhido em campo. São uma unidade de sentido para os vivenciadores e de inteligibilidade para quem observa, ajudando a entender a lógica dos interlocutores.

\section{campo}

Em um primeiro momento busquei entrar em contato com a experiência dos vivenciadores com ida a campo orientada por um conjunto de questões que permitiriam aproximar-se do universo de escolhas de algumas pessoas. O questionário foi formulado para permitir desdobramentos e seria um primeiro contato para selecionar alguns informantes. As perguntas seguem transcritas abaixo:

1. Você é daqui? Onde nasceu? Se sentir a vontade, em que ano nasceu?

2. Como é seu dia a dia? Trabalha? Sempre trabalhou nisso? E descanso?

3. O que faz quando tem tempo? O que gosta de fazer para descansar ou se divertir?

4. Como começou a vir aqui? quem te trouxe? Lembra da primeira vez? Mudou muito? Conhece a História desse lugar?

5. Essa represa, sabe como foi formada?

6. Para quê serve essa represa?

7. De quem é essa represa? tem um dono? é privado ou é do estado? qualquer pessoa pode usar?

8. Quem usa a represa (ou esse lugar)? e quem abusa dela?

9. O que as pessoas falam desse lugar? Você concorda? Quando ouviu falar daqui pela primeira vez?

10. Tem fotos daqui?

11. Como você se sente nesse lugar?
12. O que a represa te faz lembrar?

13. Como você chama aqui?

14. Você já viu alguém fazendo alguma coisa estranha aqui?

15. Você acha que tem gente que usa o espaço melhor que outros? Ou pior?

16. Você sabe como é a qualidade da água? Dá peixe? Dá lixo? Dá bicho?

17. Se você pudesse fazer alguma coisa para melhorar aqui, o que faria?

18. Se tivesse escolher outro nome para esse lugar, qual seria?

19. Quais são as turmas que frequentam aqui?

O que se percebeu, após a realização das primeiras entrevistas ${ }^{79}$ é que essa abordagem, não permitiu que se estabelecesse uma relação de proximidade entre entrevistador e entrevistado. As respostas eram curtas e limitavam-se a poucas frases, insuficiente para entender o significado do lazer para aquelas pessoas a não ser de modo mais superficial, como quem responde a marca preferida de sabão quando perguntado na rua. Algumas passagens ofereceram belas imagens, mas ainda deixaram uma impressão de que outra estratégia deveria ser adotada.

Magnani em sua tese coloca:

"Se as informações obtidas através das entrevistas e questionários permitiram construir, como primeira aproximação ao universo do lazer em Três Corações ${ }^{80}$, um quadro geral das modalidades prefe-

79. No feriado de 02 de novembro de 2018 foram feitas entrevistas usando como fio condutor o questionário acima, mesmo o resultado tendo sido mais superficial, foram usadas algumas passagens mais representativas.

80. O autor acompanhou a desmontagem e montagem do circo Rosemir em dois bairros do Grajaú durante a pesquisa para o doutorado, cuja tese foi defendida em 1982: o Jardim Eliana, bairro em que viveu boa parte da vida Enivo, um dos entrevistados, e Três corações, que fica atrás da cohab Faria Lima. 
ridas de entretenimento, eram ainda insuficientes para se chegar à compreensão do lazer realmente desfrutado pelos moradores da vila. Tentar enriquecer este quadro, no entanto, estendendo o raio de aplicação daqueles instrumentos de pesquisa, não parecia como a alternativa mais apropriada para fazer avançar a análise: ou bem se realizava um levantamento completo sobre a base de uma amostra representativa, ou então se experimentavam outras estratégias. Algumas entrevistas em profundidade - destinadas a captar um discurso mais fluido e contínuo - tampouco se revelaram eficazes, não porque o resultado fosse fragmentário, desarticulado: o discurso simplesmente não se desencadeava. Ou seja, chamava atenção a dificuldade das pessoas em superar o estágio monossilábico de suas falas sobre lazer, por um lado, e a flagrante distância entre o nivel do discurso e o da prática real de lazer, por outro" p. 199

No segundo momento a entrada em campo se deu via conexões da Universidade. Embora eu tivesse relutado em adotar esse caminho, me pareceu um atalho possível diante de um prazo exíguo para conseguir "colher os frutos do campo". No Cantinho do Céu, o contato foi feito através da arquiteta Melissa Matsunaga, que em 2015 apresentou para a FAU-USP a dissertação "Cantinhos do Céu". Além da pesquisa sobre a paisagem dos bairros Cantinho do Céu e Parque Residencial do Lagos, com enfoque nos moradores e ex-moradores, Melissa fez parte da equipe de projeto do escritório Boldarini Arquitetos Associados durante o período de projeto e implantação do Parque Linear. Na Prainha, o primeiro contato foi feito com a arquiteta Luciana Ferrara, professora adjunta da Universidade Federal do ABC, pesquisadora de longa data dos mananciais de São Bernardo e que teve contato com a gestão anterior, quando se reali- zaram as intervenções na Prainha. Através dela recebi o contato da ex-diretora de Planejamento Urbano de São Bernardo do Campo, Claudia Virginia Cabral de Souza que esteve na gestão que executou o projeto de renovação da Prainha em 2014.

Esses contatos permitiram que fossem mapeadas as primeiras conversas que serviriam de base para a definição de quem seria a rede de interlocutores. Com alguma sorte também, consegui formar uma outra rede através do contato sem mediação de outros pesquisadores com o Subprefeito do Riacho Grande, que acabou por ajudar a construir outra rede de interlocutores.

Decidiu-se então acompanhar os vivenciadores da represa com objetivo de revelar e apreender os padrões de comportamento e como a vida dos mesmos transcorre na paisagem da represa no contexto do lazer. Paralelamente, analisou-se as narrativas de alguns técnicos que atuam nos instâncias municipais e regionais de gestão da represa ${ }^{81}$.

Ao trabalhar no cotidiano dessas pessoas, foi possivel iluminar algumas perspectivas que dificilmente seriam acessadas sem que o contato fosse mais íntimo, o que exigiu que as primeiras conversas se estendessem posteriormente por entrevistas gravadas, quando possível, e trocas posteriores ${ }^{22}$.

Os assuntos que abordei nas entrevistas foram distintos de acordo com os entrevistados. A seguir, apresento alguns trechos que contribuem para constituir uma narrativa sobre os espaços estudados bem como procuram iluminar alguns aspectos que considerei importantes na vivência dos mesmos.

81. Verificar lista de entrevistados apresentada na introdução da dissertação.

82. Os contatos permaneceram durante todo período da pesquisa. 


\section{A Represa no olhar de seus vivenciadores}

\section{Prainha do Riacho Grande}

"A represa é multiuso. A história da represa como turismo, como lazer, começou na década de 1960, que eu acompanhei. A pesca, a profissional acho que começou antes, mas a pesca do lazer, pesca de varinha, começou na década de 1960, se firmou na década de 1970 e cresceu na de 1980, tanto que o comércio de produtos voltados à pescaria ferveu nessa época. Hoje, ele está bem fraquinho porque o peixe também sumiu. Então, o pessoal vinha de tudo quanto era lugar, porque tinha muito peixe. Você pescava peixes grandes, bagres, trairas; tilápia de um quilo; pegava no anzol, traíra de dois, dois quilos e pouco; carpas. Tinha uma oferta de peixes bastante grande, e era um atrativo. Teve um sujeito, que era pintor de quadros, que montou uma cantina na beira da represa para casais. Isso aípegou muito. Eaícomeçou a aumentar também a oferta desse tipo de bar para casais. Essa orla da Prainha começou a ficar conhecida em qualquer lugar do $A B C$ como lugar para casais, e o pessoal começou a vir muito. Começou a vir o casal à noite, mas depois vinha com a família durante o dia, sábado, domingo, frequentar a beira, por isso começou a tornar-se uma praia. Por que Prainha? Porque dava para nadar, era raso. A represa em si é cheia de barrancos perigosos"

Abro esse capítulo com uma fala de Ivar por dois motivos: o primeiro deles é porque o relato dá conta de algumas entradas possíveis para uma primeira visão do lazer da Prainha. O segundo é porque Ivar se tornou meu principal interlocutor para assuntos da Prainha desde que o entrevistei pela primeira vez. Suas falas são apresentadas aqui no papel de quem vivencia os espaços da represa e a rede de sociabilidade formada em torno de si e não no papel de representante do poder público constituído.

Desde o primeiro encontro, quando estava há apenas 90 dias nomeado e empossado para a subprefeitura do Riacho Grande, Ivar foi solícito em todas as ocasiões em que conversamos.

Essa relação permitiu que eu tivesse acesso a outros moradores, e também fez com que de certa maneira as relações estabelecidas tivessem a marca dessa relação pré-existente, afinal eu era para as pessoas a "jornalista" amiga do Subprefeito. Entre- 
tanto, essa relação facilitou o contato e o trânsito de informações com outras pessoas do Riacho.

Durante a primeira conversa que tivemos, em seu gabinete, Ivar me conta que mora há 59 anos no Riacho e que mesmo não tendo ocupado cargos políticos antes, sempre foi ativo nas questões políticas, ambientais e comunitárias do distrito ${ }^{83}$. Após às eleições de 2016 em que se elegeu Orlando Moraes, de seu grupo político, foi convidado a fazer uma consultoria na Fundação Criança ${ }^{84}$. Em seguida foi convidado pelo mesmo para assumir a subprefeitura do Riacho.

Aluno da primeira turma do ginásio do Riacho junto com Solange, filha de Leli, conta que sempre teve boa relação com a comunidade devido seu engajamento em questões diversas, desde a alteração do viaduto abaixo da Anchieta, passando por órgãos do meio ambiente e órgãos de segurança pública. Quando indagado sobre qual o papel da represa em sua vida, Ivar convoca sua memória afetiva de infância, lembrando que passava o tempo livre com os irmãos nas margens:

"Eu aprendi a nadar aqui. Vinha com meus irmãos mais velhos. Na época, a gente morava na Balneária. Comecei a aprender a nadar na represa com eles. la pescar também, e quando a represa secava, a gente fazia um campo de futebol na parte seca. A gente tinha uma relação assim: nadar, jogar bola e andar a cavalo na beira da represa".

83. É membro do Conselho de segurança do Riacho Grande, foi presidente do MDV - Movimento em defesa da Vida do ABC, é diretor e fundador do Fórum dos moradores do Distrito de Riacho Grande e Presidente da Comissão de Meio Ambiente da OAB SBC além de ter saído candidato a vereador nos anos de 1988, 1996, 2000, 2012 e 2016, este último pelo PSDB. Conheceu o atual prefeito em 2001 quando Orlando era vereador e fez campanha para o mesmo em 2002 para deputado federal, fazendo parte do atual grupo político do mesmo.

84. Instituída em 26 de novembro de 1998 e atendendo as diretrizes e normativas da lei 8069/90 - Estatuto da Criança e do Adolescente a Fundação Criança de São Bernardo do Campo é uma fundação pública municipal, com missão, diretrizes e objetivos focados na defesa e garantia de direitos de crianças, adolescentes e jovens.
As memórias da represa me levam a perguntar sobre o presente, qual seria a forma com que as pessoas usam a Prainha na atualidade. A primeira referência que ele me dá é a procissão de Nossa Senhora dos Navegantes, geralmente no primeiro domingo de fevereiro, depois o festival de verão, nos três últimos finais de semana de janeiro:

Temos, por exemplo em fevereiro, normalmente o primeiro domingo tem a procissão da Nossa Senhora dos Navegantes. Essa procissão é histórica (...)Temos um evento que é o show de verão que a prefeitura promove que traz artistas de nome nacional que são três finais de semana em janeiro, sábado e domingo, estamos indo para a terceira edição. Tivemos a primeira edição em 2017, segunda edição em 2018 e vamos para a terceira edição agora em 2019. Esse é um evento grande, isso na Prainha. Fora isso tem algumas atividades, mas isoladas.

Embora, segundo Ivar, sejam poucos os eventos de grande porte, no meu entendimento o cotidiano da Prainha já é um "evento de grande porte". Durante o verão 2018-2019, até início de março, quando a represa ainda não tinha recebido os aportes do bombeamento do Pinheiros e as chuvas de março ainda não tinham aparecido, ou seja, a represa ainda estava baixa, deixando uma larga faixa seca nas margens, a visão da faixa de "areia" ocupada era comum, até mesmo nos dias menos ensolarados.

A Prainha é uma boa expressão do conceito de mancha: com um público diverso e várias faixas de renda, recebe aos finais de semana famílias que vem a pé do Areião, trazendo o farnel e as crianças para passar o tempo no talude da represa, famílias de outras localidades, que montam seus guarda-sóis e mini churrasqueiras embaixo do deck, empresários do ABC que vem na hora do almoço pegar o "jet" 


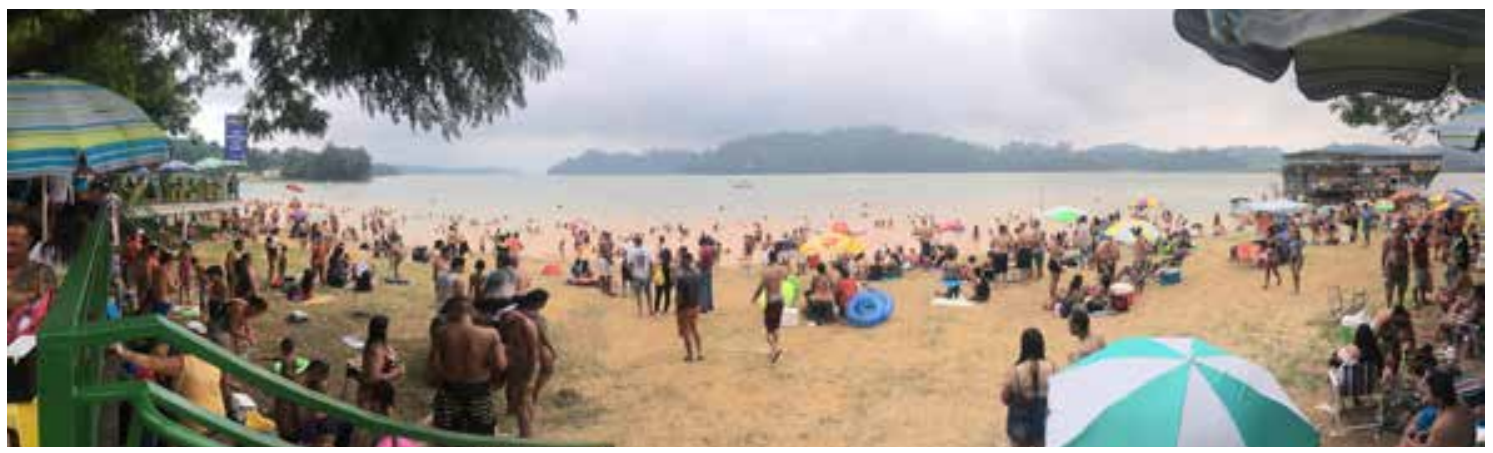

[51] Prainha em janeiro

Carolina Gimenez, 2019

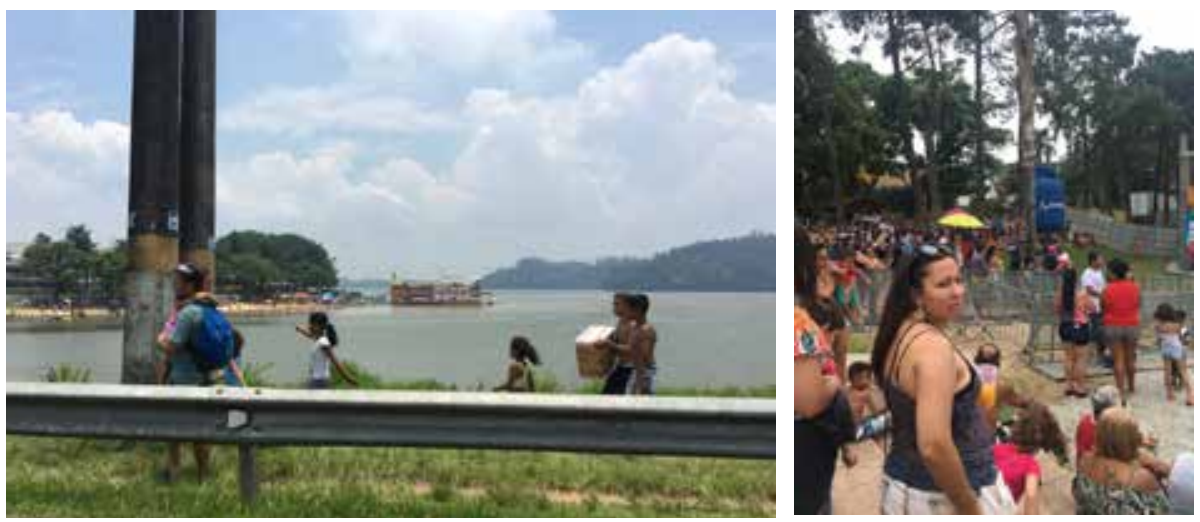

[52 e 53] Família atravessando a Anchieta em direção à Prainha/ festival de verão Carolina Gimenez, 2019

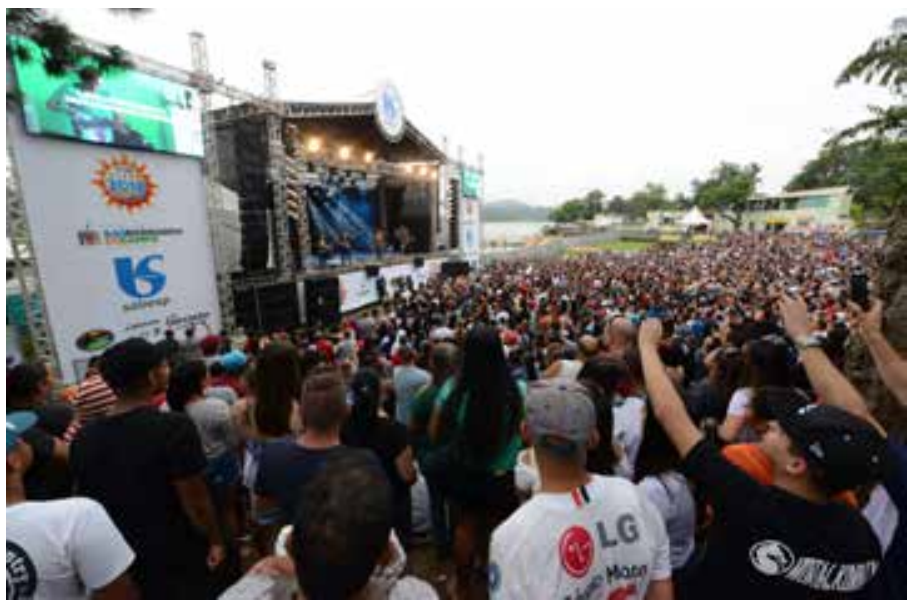

[54] Prainha durante o festival de verão 2019. Foto de Omar Matsumoto 
para almoçar nos restaurantes da rota do peixe no Rio Pequeno, aposentados de São Bernardo que vem pescar nas margens, entre outros públicos.

Os preços não são baratos, para um passeio de barco em família por exemplo gasta-se $\mathrm{R} \$ 120$ por 20 minutos. O marinheiro Cláudio, um dos poucos que faz passeio de lancha, justifica o preço atribuindo aos altos encargos que paga, além de ser o "único que tem licença e empresa para transportar pessoas".

O gosto por barcos veio do pai, que sempre gostou de embarcações. Foi assim que surgiram o Nautilus e o Atrevidus, dois dos flutuantes ancorados no pier da Praça Olavo Fontoura. O pai de Claudio adquiriu ambos em leilão, onde foram vendidas embarcações utilizadas para as obras da represa. Inúmeras adaptações foram feitas até chegarem a sua forma atual, com um salão no térreo e uma varanda no topo. Por algum tempo a família administrou os dois restaurantes com outros sócios, mas com o tempo e com os desentendimentos a família de Claudio preferiu ficar somente com o Nautilus.

Nas conversas que tive com o marinheiro havia sempre um tom de melancolia e revolta. Suas maiores reclamações referiam-se a falta de fiscalização das atividades na água e irresponsabilidade "da turma do jet-ski", tanto de usuários como de outros marinheiros que levam na garupa da moto náutica, fato que pude observar em diversas situações de embarque e desembarque de passageiros. Claudio reafirmou inúmeras vezes em nossas conversas que estava cansado daquela "bagunça" e da "terra sem lei", e um dia falou: "aqui parece que o certo é ser errado". O discurso permeava um certo conservadorismo quando se estendia ao que ele chamava de "invasões" na represa, a direitos trabalhistas dos funcionários, a presença de criminosos e "vagabundos" nas águas da represa, entre outros. Um dia, ao ser consultado sobre valores para me levar até o Cantinho do Céu em sua lancha me falou: "você tá louca, só tem maloqueiro ali, além dos piratas da Billings". Olhando minha cara de espanto, explicou sobre a existência de "piratas" que navegavam na represa assaltando e matando marinheiros como ele. Um dia, conversando com Cláudio numa sexta-feira à tarde, falamos sobre uma possível venda do flutuante da família, porque segundo o marinheiro, já não dava mais para ficar ali, quando ele me pergunta: "você já viu trabalhador parar essa hora para ficar aí na represa de jet ski? Isso aí é tudo vagabundo do crime organizado ${ }^{85 " .}$ Se aqueles eram ou não criminosos, é difícil afirmar, porém Ivar já havia comentado, em outra ocasião, que não era incomum ver um pessoal "estranho descer moto náutica na represa" e afirmar que se tratavam de pessoas relacionadas ao crime organizado.

A informação sobre piratas na Billings não é exatamente uma "lenda urbana". No ano de 1999 houve um assassinato em decorrência da tentativa de um comerciante resgatar o filho que estava sob custódia de "piratas"86. Posteriormente foram relatados casos de assaltos de motores de barcos em diversos pontos da represa ${ }^{87}$, levando a construção de um imaginário de piratas agindo permanentemente na represa por parte de Claudio.

Lucas Cavinato, proprietário da Marina Billings Jet Parking, tem uma visão um pouco diferente: ele relata saber da existência de roubos a motores e se lembra da história do assassinato em 1999, mas atribui os roubos a facilidade com que se retira um motor de um barco

85. Claudio cita a facção criminosa, porém preferi omitir essa informação aqui por questões de segurança

86. O caso teve repercussão na Folha de São Paulo: "Piratas atacam turistas na represa Billings" Folha de São Paulo. 16 de Dezembro de 2001. Disponível em: <https://www1.folha.uol.com.br/fsp/cotidian/ff1612200134.htm> Acesso em 18 Set 2018

87. "Represa Billings não está para peixe" Diário do Grande ABC. 10 de agosto de 2004. Caderno Setecidades, p.2 
e que portanto é necessário muita precaução de não deixa-los ancorados na água em regiões com menos movimento. O exemplo que ele usa parece bem didático: "Eu trabalho apenas com moto-náutica, que é até mais fácil de levar embora que um motor. Você já viu alguém deixando moto sem corrente na rua? Então, por isso que eu tenho cuidado de sempre trazer as motos aqui para a garagem, não deixo na água ali na água vacilando depois que o camarada usou. A carreta de transporte também nunca fica no mesmo lugar que as motos, só fica quando está em uso".

Lucas abriu a marina há dois anos, no lugar antes ocupado pela quadra poliesportiva da escola que a mãe construiu. Relata que cobra uma mensalidade de $\mathrm{R} \$ 300$ e que a maior parte de seus clientes é empresário de São Paulo ou São Bernardo, muitos deles aparecem aos sábados e domingos para passar o dia na represa ou vem almoçar na rota do peixe em dias de semana. A mancha pode ser percorrida por terra ou por água: de moto náutica são 20 minutos até o restaurante Netuno, um flutuante ancorado próximo a ponte do Caminho do Mar com o Rio Pequeno; por terra, sem trânsito, leva 15 minutos, metade da distância percorrida por quem vai pela água.

O empresário relata que a ideia de abrir a marina foi idealizada com sua mãe, Lucia, para fazer "render melhor o terreno da escola", que já estava em dificuldades financeiras em 2017.

Lucia é professora aposentada do Estado e decidiu no final da década de 1980 abrir uma escola particular no Riacho Grande. Sua família tem parentesco com o João Cavinato, o João da Ponte ${ }^{88}$, viviam no centro de São Bernardo até 1988, quando Lucia comprou o terreno da escola e a casa onde vive e trouxe os 4 filhos para morar junto.

Lucia tem 50 anos de experiência em educação,

88. Ver relato de Leli no capítulo anterior "Riacho Grande: Histórias, Memórias e Paisagem". se diz um pouco cansada de trabalhar e desanimada com a quantidade de exigências que foram feitas as escolas particulares para atender a acessibilidade universal dos alunos: "eu só tive dois alunos especiais, um com síndrome de down, mas que não tinha nenhuma questão motora, e outro que era mudo, e ainda assim fizemos as rampas de acessibilidade para o primeiro andar. Mas aí começaram a nos cobrar 'acessibilidade universal', ou seja, todos os recintos precisariam ser adaptados, como eu faria com os escritórios aqui embaixo? Plataformas são muito caras. Vai ver se alguma escola municipal tem isso". Como a escola foi perdendo alunos nas turmas ano após ano, chegando a apenas 50 alunos em 2018, resolveu fechar as portas, pois não teria fôlego para todas as mudanças que seriam necessárias no espaço.

De todo modo, Lucia segue atuante na "comunidade" que apelidou de "cidade do interior". Faz parte do Conselho Comunitário de Segurança (CONSEG) do Riacho Grande ${ }^{89}$, onde, segundo ela, ocorrem as menores taxas de criminalidade de São Bernardo ${ }^{90}$, discurso também compartilhado pelo Subprefeito Ivar, que também faz parte do CONSEG. As reuniōes acontecem uma vez por mês e qualquer um pode endereçar irregularidades ou solicitações ao conselho. Comentei sobre as reclamações do Claudio sobre a fiscalização dos passeios irregulares de moto-náuticas e Lucia me falou: "Ele veio aqui uma vez e depois não voltou nunca mais. As coisas

89. O CONSEG III cobre a área do $3^{\circ} \mathrm{DP}$ e da $3^{\mathrm{a}} \mathrm{CIA}$ do $40^{\circ}$ Batalhão da Polícia Militar, compreendendo a área a oeste daVia Anchieta até o Riacho Grande,

90. A informaçāo não é completamente verdadeira. No mapa da criminalidade de da Secretaria de Segurança Pública o Riacho Grande aparece com uma quantidade significativa de ocorrências, porém as mesmas se concentram em regiōes mais afastadas da Vila do Riacho, onde Lucia reside. Ver <https://www.metrojornal.com.br/ foco/2019/02/28/maioria-homicidios-longe-centro-abc.html $>$, <http:// www.soudapaz.org/upload/pdf/diagnostico_saobernardo_2006. pdf $>$ ambos com acesso em 01.Mar.2019 


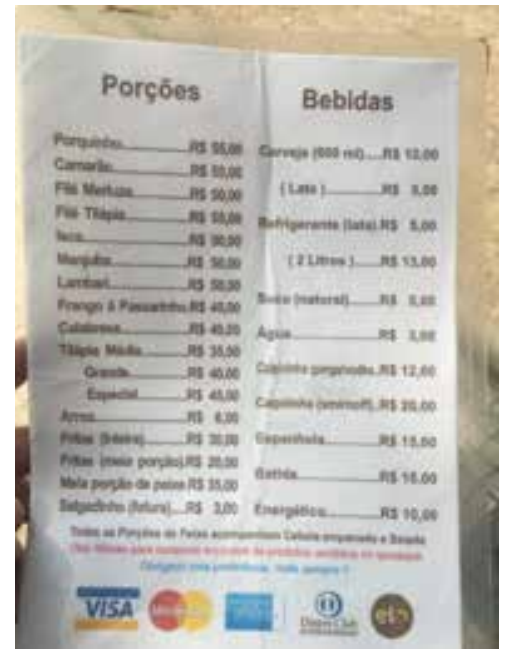

[55] Exemplo de cardápio do que é servido nos quiosques, que como a maior parte dos estabelecimentos tem temática "pescados". O cardápio neste caso é do quiosque do Carlos, presidente da associação.

Carolina Gimenez, 2019 no poder público demoram, e aqui somos só um conselho consultivo, tem ficar em cima dos órgãos competentes depois, tem que participar. Água mole em pedra dura...." Lucia comenta que a principal reclamação dos moradores no CONSEG refere-se aos mendigos, que segundo ela são mandados de perua da baixada santista até o Riacho. Pergunto se ela já testemunhou isso acontecendo:

" Já vi. Não se sabe de onde vem, mas enchem a perua de "drogado" e mandam para cá, porque lá na baixada tem muito (drogado ou mendigo, não fica claro). Aí eles dormem na prainha, porque lá tem aqueles buraquinhos, e aqui tem o coreto, eles dormem e se instalam aí. Já notificamos, e etc. e tal (...) a gente tem que conviver, eles não são, para mim, um problema. Mas a turma reclama muito porque fica na Praça, é depreciativo...e o policial não pode tirar, porque todo mundo tem o direito de ir e vir. Acontece eles (quem reclama) querem levar para CRAS (Centro de Referência de Assistência Social) mas eles (mendigos ou drogados) não vão, porque lá tem regras. O principal problema aqui e no Brasilé a droga, e os pontos ficam todos em praça pública. Aqui o pessoal reclama muito da Prainha à noite."
A fala de Lucia dá conta de um fenômeno que já havia apontado como um problema do projeto: o deck suspenso resulta em um "não-espaço" abaixo de si. A relação que se tem com a paisagem para quem está em cima é interessante, mas seriam necessárias mediações entre a cota do deck e a cota da orla. De todo modo, na maior parte das vezes que visitei o deck suspenso nota-se uma grande diversidade de pessoas: desde famílias a grupos de homens jogando dominó, jovens escutando funk e casais namorando e mesmo com preços não tão populares, isso não afasta quem tem pouco ou nenhum dinheiro sobrando, e afinal, sempre sobra um para a "cervejinha" do final de semana.

Ando em frente aos quiosques para tirar algumas fotos e topo com Carlos Vieira, presidente da associação e dono do quiosque 8 . Como quem nota a presença de um estranho, ele me pergunta o que que eu estava fazendo ali, depois de ter me visto tirando algumas fotos da estação de tratamento de esgotos. Me apresento, mostro a carteirinha de estudante e ele muda um pouco o semblante desconfiado com que tinha iniciado a conversa e assim recomeçamos a conversa de um jeito mais amistoso. Ele me oferece um refrigerante e então eu pergunto sua opinião 
a estação e ele é categórico: "o corredor ${ }^{91}$ tronco deveria passar na Anchieta, tirando a estação dai". Assinto, e comento que essa é uma demanda do Subprefeito Ivar, mas que envolve muita articulação para se realizar. Percebo então que Carlos fica um pouco incomodado com o nome que eu havia citado e tento tatear por quê. Ele conta que durante o festival de verão haveria um acordo da Ambev com os comerciantes dos quiosques que não prosperou, levando a um desentendimento entre ambos, uma vez que Carlos fez uma cobrança pública ao Subprefeito, mas que segundo o comerciante "faz parte da política a gente cobrar né? Mas já tá resolvido".

Segundo Carlos o projeto de revitalização da Prainha "tava errado, primeiro porque queriam tirar a gente daqui a qualquer custo, e por isso nasceu a associação, porque ninguém defendeu a gente. Sabe quem deixou a gente ficar aqui? O Juiz, que viu que a gente era tudo trabalhador. Era um juiz jovem, tinha um pensamento diferente. Você pode ir lá ver, tá tudo lá nos autos". Demonstrando um conhecimento da terminologia técnica do processo de reintegração de posse que havia sido solicitado pela EMAE, a fala se distancia um pouco da versão oficial ${ }^{92}$, em que a permanência dos comerciantes na orla havia sido uma prerrogativa do município.

Mas o problema maior, segundo o comerciante é que a Prainha não comportaria os 20 quiosques, "muita gente pra pouco público". "Mesmo no pico do verão?", pergunto. Carlos fala que com o movimento "igual de praia" o comerciante tem "ganhar no verão

91. O termo correto é coletor tronco, porém a imagem de corredor parece funcionar. É a tubulação que faz parte do sistema de coleta de esgotos que recebe contribuiçōes das redes coletoras e que conduz a um interceptor, este último leva os esgotos até uma estação de tratamento. O entendimento dele está correto sobre a solução, uma vez que para a remoção da estação, o esgoto da Vila do Riacho deveria ser encaminhado para a ETE ABC, na bacia do Tamanduateí.

92. Conforme Nilza Oliveira, Secretária de Orçamento e Planejamento Participativo na gestão de Luiz Marinho. e poupar no inverno" e nem todo mundo "aguenta" e que mesmo o festival de verão não trouxe o retorno que ele esperava. Lucia, de um outro ponto de vista também questiona o número de quiosques, que segundo ela era arbitrário:

\begin{abstract}
"Veio até o ministro do Turismo aqui ver. Mas assim, não era para ter quiosque nenhum. O projeto não era esse, era bem melhor, e não tinha barraquinha nenhuma. Meio ambiente não combina com comida.. Tinha que fazer uma praça separada de alimentação. Aquijáfoisede de disputa náutica, pararam porconta da invasão das barraquinhas... aqui era para fazer um jardim bem bonito. Eu perguntei ao Wagner Lino (subprefeito na época): 'mas porquê 20 quiosques', ele respondeu: 'nós aceitamos 20, porque tem gente de fora do Riacho também, coitados'".
\end{abstract}

De família simples e morador do Riacho há 45 anos, veio com a família, de Santa Catarina, em busca de oportunidade. O pai, trabalhador da construção civil, conseguiu um "terreninho" na Vila Pelé, onde Carlos mora com a família até hoje. O bairro, que já foi favela, cresceu com o "esforço das famílias e ajuda do Marcos". "Marcos?", eu pergunto, "foi subprefeito do Walter Demarchi, o único que realmente fez algo pelo Riacho". Carlos então propõe uma ideia: "o Riacho tinha que se emancipar. Temos três fabricas de dinheiro aqui". Percebendo que eu não acompanhava o raciocínio ele me responde: "Você sabe quanto de dinheiro dá um pedágio? Então, só aqui no Riacho são 3, um no rodoanel, outro na Anchieta e outro na Imigrantes".

Andamos no deck em direção a represa e ele aponta em direção ao que seria o pedágio do rodoanel. Nesse dia, como durante boa parte do período da chuva, a represa está bem alta, escura e aparentemente saudável. Pergunto para Carlos como ele 
faz para servir as pessoas na parte de baixo quando a faixa seca fica tão estreita. "Quer saber minha opinião? A gente não devia servir lá. Não devia nem montar mesinha, porque obstrui toda passagem. E se alguém se afoga, como já aconteceu aqui? O bombeiro nem consegue chegar. Fora que fica toda essa sujeira aí que você tá vendo".

Entre os entrevistados que responderam ao questionário, privilegiei aqueles que estavam na faixa seca, em contato direto com a represa. Era feriado de 02 de novembro de 2018 e embora estivesse nublado, o dia estava relativamente quente atraindo bastante gente. Entre os entrevistados, apenas um casal morava em São Bernardo, na Vila Balneária, bairro pertencente ao distrito do Riacho Grande e que fica no lado oposto da represa. O casal jovem viera de bicicleta e estavam saindo um pouco da rotina, como disseram, já que aos finais de semana costumam ficar em casa vendo televisão. Apesar de considerarem naquele dia a visita à Prainha uma exceção, ambos têm memórias de infância de estar na represa brincando, e afirmam frequentar desde de 1996, o que sugere que talvez frequentar a orla não a exceção como apontam. Os outros eram todos da Região Metropolitana de São Paulo: Santo André, Itapecerica da Serra, São Paulo, e São Caetano. Essa pequena amostra de pessoas dá conta de uma condição singular: trata-se de uma praia metropolitana.

\section{"Se eu pudesse morar aqui, eu moraria"}

" (...)quando eu cheguei eu comentei que se eu pudesse morar aqui, eu moraria. Porque eu acho muito tranquilo, e é o meu jeito de ser. Já ele comentou que não, ele gosta mais de um local agitado, para passear tudo bem. Eu moraria aqui, se eu tivesse condições financeiras para comprar ou alugar. O problema maior aqui também que eu vejo é a distância, eu teria que vir de carro ou de ônibus, que na realidade eu não sei como pega, porque eu vim de carro".

A frase acima, presente na fala de Vera, frequentadora da Prainha, dá conta de fenômenos que vai aparecer na fala de outros entrevistados de outras maneiras: a Prainha é um lugar onde as pessoas se sentem bem, em paz, tranquilas, livres e confortáveis o suficiente para considerar a hipótese de morar ali. Quando perguntado como se sente na represa, Júlio responde:

"Eu me sinto livre, como eu te falei, eu gosto dos dois lados, gosto muito da natureza e gosto muito de lugares fechados. Mas aqui eu me sinto livre, a gente vive no nosso trabalho, a sociedade cobra muito postura, a gente vive num ambiente de regras e comportamentos, e acho que aqui você está em um momento em que você pode ser você mesmo, ficar na natureza, fazer aquilo que você gosta, não pensar em nada que seja cobrado no dia-a-dia"

Embora a circulação não seja assim tão livre, para quem não vem a pé ou de bicicleta, já que os acessos são ruins, com poucas linhas de ônibus chegando ao centro do Riacho, isso não afasta os visitantes, que às vezes ficam horas no trânsito da Anchieta para conseguir entrar no bairro.

Essa questão é um assunto que aparece em outras falas. Para quem realmente mora no Riacho, por vezes é difícil esse fluxo de pessoas de "fora", que além de sobrecarregar as vias do loteamento Parque Riacho Grande, faz com que a entrada e saída do bairro fique congestionada por horas.

CAROLINA: Quem que frequenta a represa atualmente? Aqui na prainha? Fica assim de gente né? SOLANGE: No verão sim. 
CAROLINA: O que o Ivar me faloué que nãoé gente aqui do Riacho.

SOLANGE: Sempre é gente de fora do Riacho. Então, é mais gente de fora que vem passar o dia... CAROLINA: Mas vocês veem algum problema, tem algum conflito?

SOLANGE: O bairro não tem estrutura para tanta gente, o pioré o trânsito que se forma, comoé uma única saida, o que complica é o trânsito. Formam fila, junta com pessoas que querem passar o dia na Estrada Velha, vem para almoçar, e também quer pegar o acesso da Anchieta.

CAROLINA: É um entroncamento... SOLANGE: Fica fila até às $16 \mathrm{~h}$ da tarde.

LELI: No fim do ano passado teve um show que foi isso.

SOLANGE: Anchieta às vezes tem fila para entrar às 16h da tarde, para vir para cá.

CAROLINA: Para voltar para o Riacho?

SOLANGE: É, quando é hora do pessoal já vir voltando. A pior questão eu acho que ainda é o trânsito, que a gente sente mais. Mas não tem estrutura, têm muito pouco banheiro...

As falas de Leli e de sua filha Solange dão conta de um fenômeno que identifiquei nas minhas visitas: a Prainha faz parte da mancha, e é utilizada principalmente por gente de "fora", mas há dentro dela o pedaço onde se comemoram os eventos mais tradicionais, como Nossa Senhora dos Navegantes e a celebração do aniversário da represa, ambas celebrações frequentada por gente de "dentro".

Entre as propostas para melhoria dos acessos a Vila, tanto para moradores como para visitantes, seria a execução de uma outra entrada para o bairro através da fábrica abandonada da antiga CBL - Companhia Brasileira de Lâmpadas, onde se cogitou, na época em que estavam sendo feitos estudos para a revitalização da Prainha, usar parte do imenso parque industrial para receber um grande estacionamento para automóveis que se dirigiam a Prainha. Para viabilizar o negócio, parte da planta seria utilizada para receber um centro de distribuição da Madel, que arcaria com parte dos custos da imensa dívida de IPTU que a antiga fábrica tem com o Município de São Bernardo. A posição estratégica da antiga fábrica tanto em relação aos acessos via Anchieta como a distância em relação a Prainha faz do imóvel "a menina dos olhos" do Distrito. Infelizmente o projeto não foi adiante na ocasião em que se discutiam os investimentos na Prainha

O que une o discurso entre aqueles que são de "dentro" e aqueles que são de "fora" é a preocupação em relação a qualidade da água. Todas as pessoas com que tive contato se lamentam do estado da água da represa. Quando, por "milagre" a Cetesb publicou o resultado da qualidade da água como boa, próxima a celebração de Nossa Senhora dos Navegantes, Ivar falou, rindo, "Tive que tirar nossas placas de água imprópria para banho, mas muita gente não acredita que está própria, inclusive eu".

\section{Nossa Senhora dos Navegantes}

Com a mudança da parte baixa da Vila do Riacho para a parte alta, devido ao represamento do Rio Grande, a Prainha passou a receber o fluxo de barcos que antes aportavam próximos a ponte do Rio Grande e se configurar como o principal ponto de encontro e parada para as saídas para outras localidades da represa. Em frente a Rua do Porto, o trânsito de barcos de carga era apenas interrompido aos finais de semana pelas famílias que iam passar o dia na represa. Além das memorias de pescarias, desde o tempo em que não se tinha represa, comparece também as festividades ligadas a tradição cristã de 


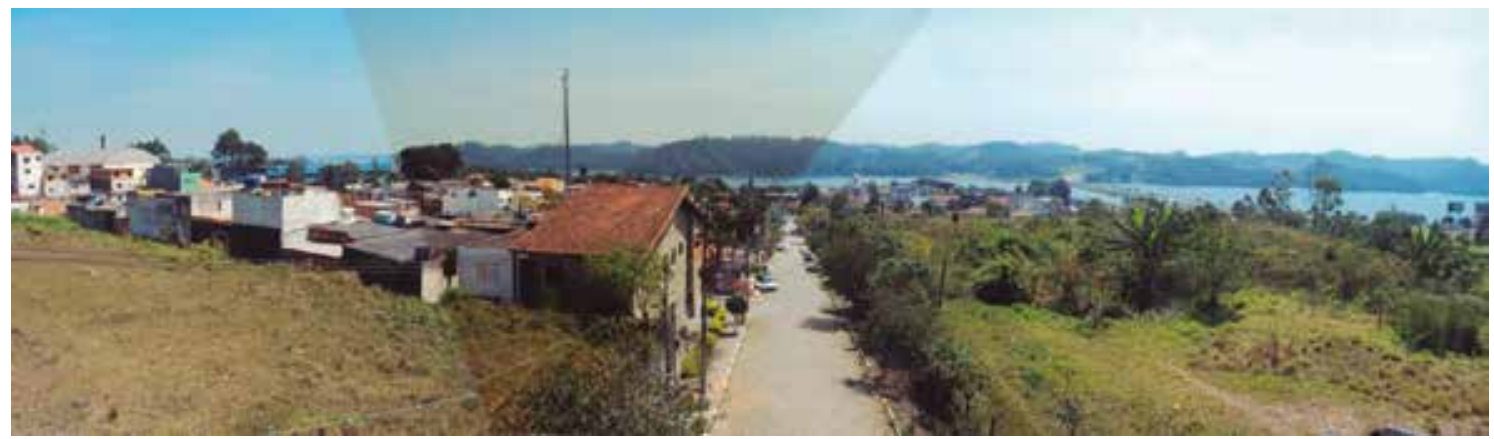

[56] Vista a partir do estacionamento da CBL em direção a Prainha.

Urbaniza Engenahria, 2010

Urb

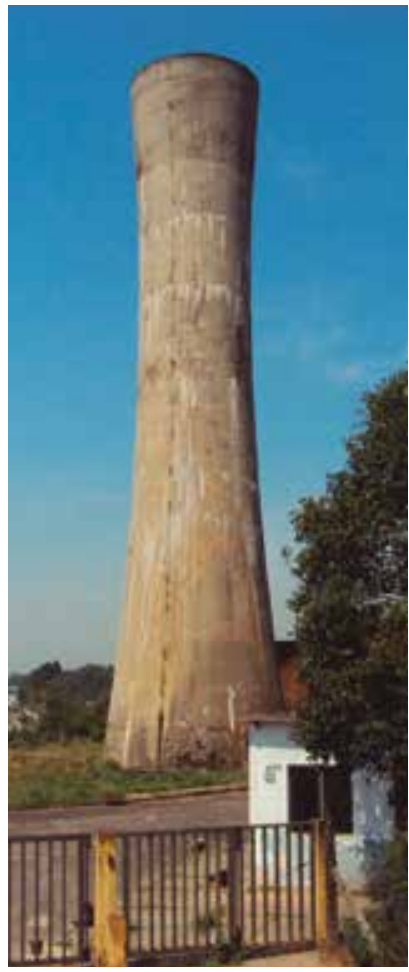

[57] Torre de caixa dágua desativada, onde se planejava instalar um mirante e um centro de atendimento ao turista. Urbaniza Engenharia, 2010

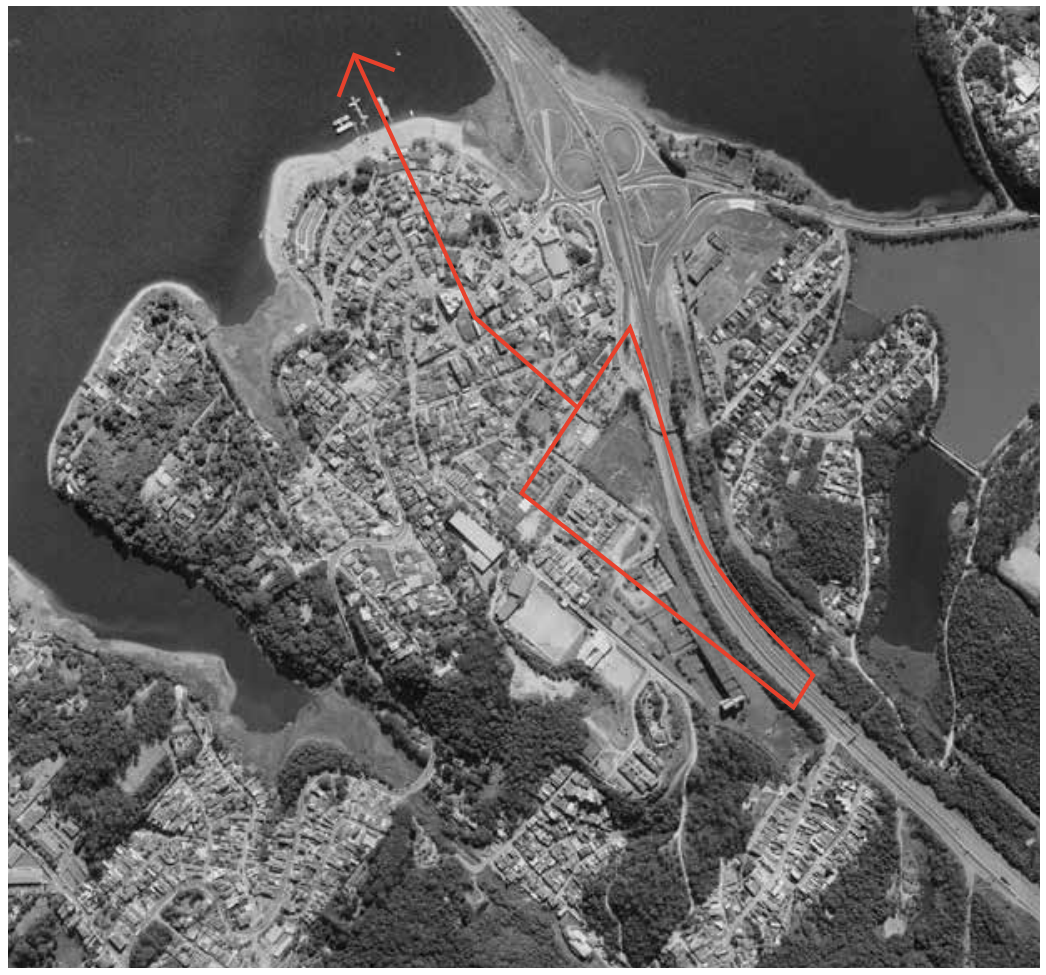

[58] Situação da fábrica em relação a Vila do Riacho Cesad-FAUUSP 
homenagem a Nossa Senhora dos Navegantes. Os moradores do Riacho durante o mês de janeiro e fevereiro faziam as comemorações e preparativos para a festa de São Sebastião, com procissão náutica até a Igreja de mesmo nome no Bororé, e Nossa Senhora dos Navegantes. Conforme relata Leli e Solange:

LELI: Então, eu fui pescar antes da represa, pescava no rio. Eu lembro que era mulecote, ia com meus irmãos pescar antes da represa chegar aqui, porque ela devagarzinho fechou as comportas em Santo Amaro e até ela aparecer aqui demorou. Foi aparecer em 1932, 33, aqui no riacho, e encheu até a cota 47. Eu, com o tempo comecei a trabalhar nos barcos, durante uns 20 anos, puxando lenha para esses batelões (...) la pescar no rio antes da represa, depois com o tempo meu primeiro trabalho foi puxando lenha aí nos batelão com meu cunhado, logo após comprei barco...Para falar a verdade, os filhos e sobrinhos se divertiram bem comigo na represa, a gente pegava o barcão, levava eles, a gente pescava, fazia café no barco com a água da represa.

SOLANGE: E a gente acompanhava nas procissões, éramos todos crianças, e era dia de festa para a gente.

CAROLINA: Vocês têm essa memória positiva de estar perto...

SOLANGE: Faziamos piquenique, que está voltando à moda hoje, já levavam a comida de casa para comermos no piquenique.

LELI: Lá no Bororé a gente ia e levava comida, a gente...

SOLANGE: Enfeitava o barco todo de bandeirola.

Embora oficialmente se diga que as festividades de Nossa Senhora dos Navegantes tenham se iniciado em 1953, Leli se recorda de fazer a procissão já no ano de 1950, quando levava os filhos para passear na represa até a llha do Bororé. Assim, o começo do ano, época também mais quente e favorável para passeios na água, era marcado pelos preparativos para as procissões.

A tradição da procissão náutica se manteve até o presente com algumas alterações. Com a abertura da capela de Nossa Senhora dos Navegantes no bairro Eldorado (atual município de Diadema) iniciou-se oficialmente a tradição com a primeira procissão entre Eldorado e Riacho Grande. No fim da década de 1970 até metade da década de 1990 a procissão deixou de ser realizada por conta da piora significativa da qualidade das águas da represa, sendo retomada em 1995 entre Riacho Grande e Diadema. Durante alguns anos, (19982003) realizou-se a procissão entre Santo Amaro e Riacho Grande, retornando a ter o ponto de partida no Riacho em 2003. Em 2015 opta-se por realizar diferentes cerimônias, uma em Diadema e outra no Riacho Grande, como tal como se fez em 2019.

Neste ano os preparativos começaram na semana anterior dentro da paroquia, com a compra do ingredientes para o almoço festivo que seria preparado para o dia da procissão náutica. Recebi o convite para "a macarronada com almôndegas" pelo Ivar, que me avisou sobre a possibilidade de embarcar em um dos barcos que acompanhariam a Santa no domingo dia 03.02.2019. Haveriam ainda 3 missas, celebradas na quinta-feira (31.01), sexta-feira(01.02) e sábado (02.02) que configurariam o "Tríduo Preparatório".

Com o tema "Maria, Mãe dos Navegantes, leva-nos para as águas mais profundas" a procissão começou no domingo dia 03 de fevereiro. A Santa foi embarcada às 7h00 em uma pick-up que a levou até a balsa João Basso, atravessando a represa até a Colônia dos Pescadores no pós-balsa. 


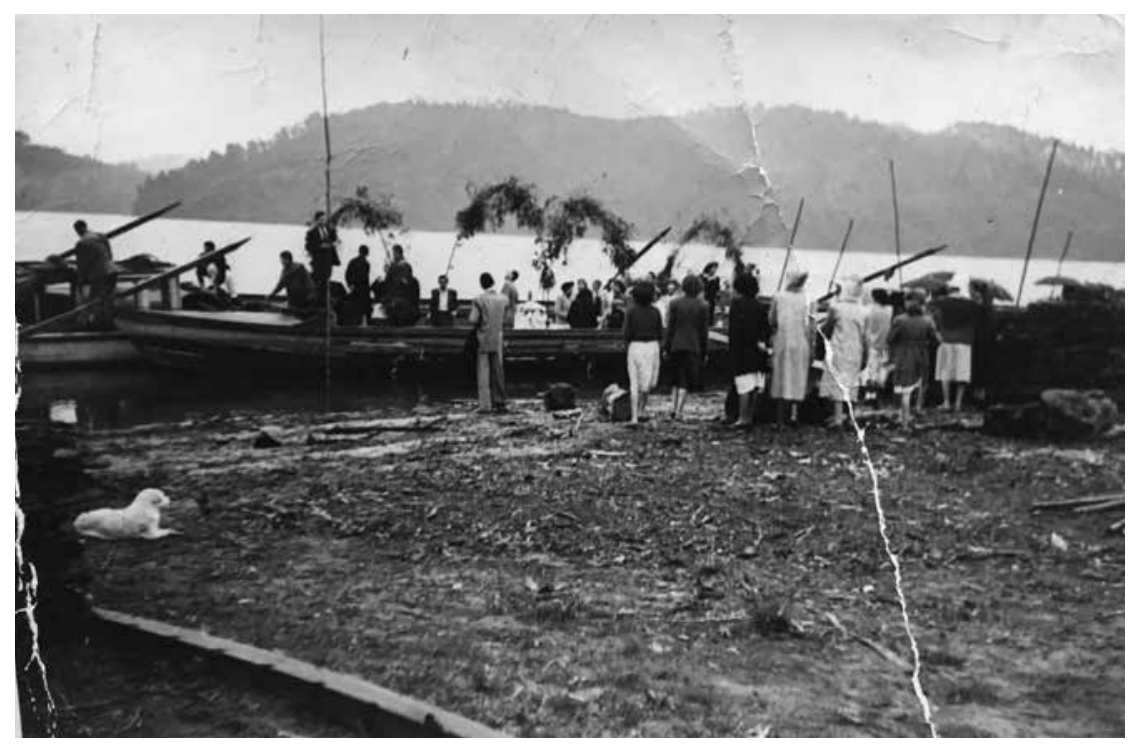

[59] Embarque de passageiros em Batelão de Leli para igreja de São Sebastião na Ilha do Bororé em 1950 durante as festividades de Nossa Senhora dos Navegantes Autor da foto: Leli

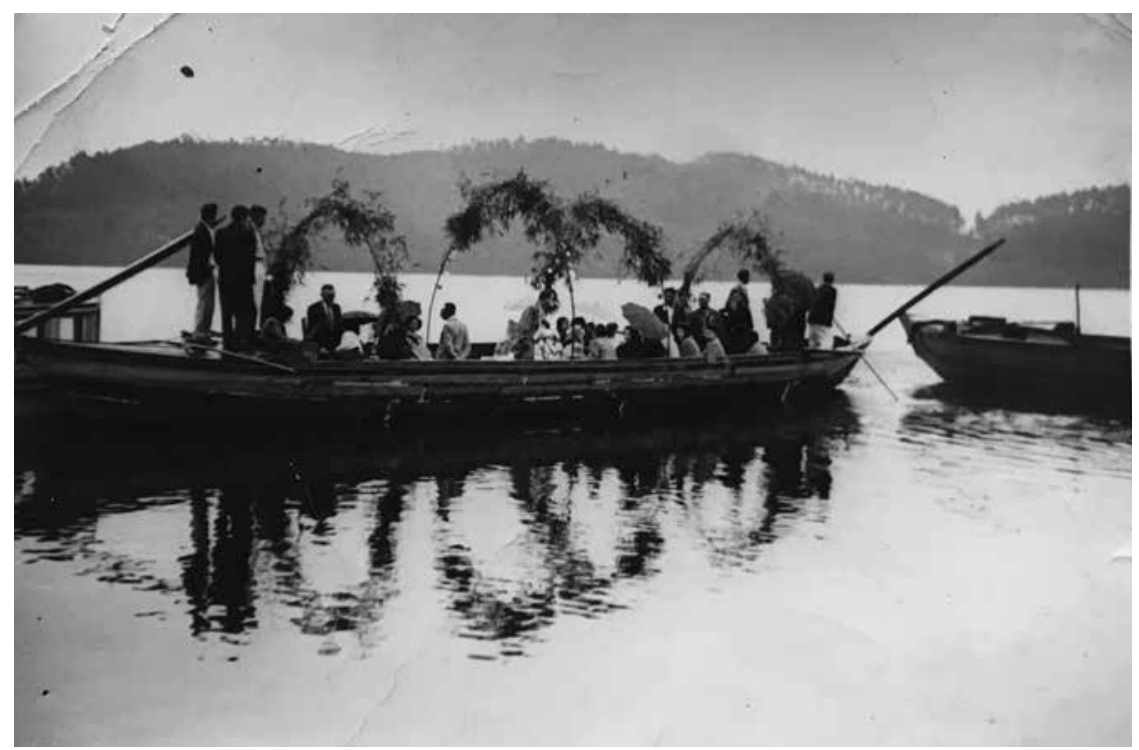

[60] Embarque de passageiros em Batelão de Leli para igreja de São Sebastião na Ilha do Bororé em 1950 durante as festividades de Nossa Senhora dos Navegantes Autor da foto: Leli 

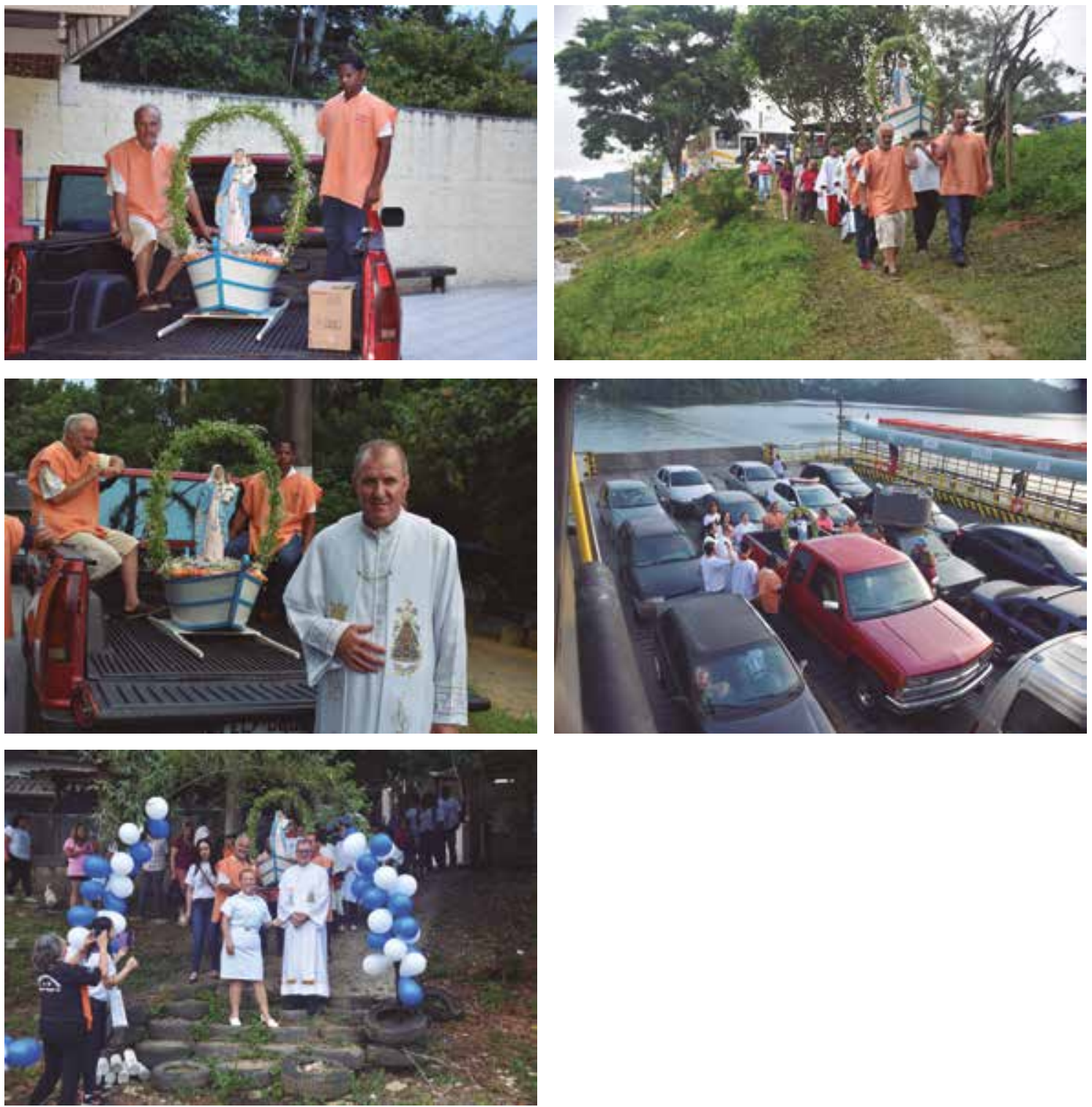

[61] Na Colônia dos Pescadores foi feita a

benção às embarcações, sendo a Santa colocada

posteriormente em um dos barcos para a procissão

náutica pela Represa Billings até a Prainha .

Ulisses Guglielmetti, 2019 

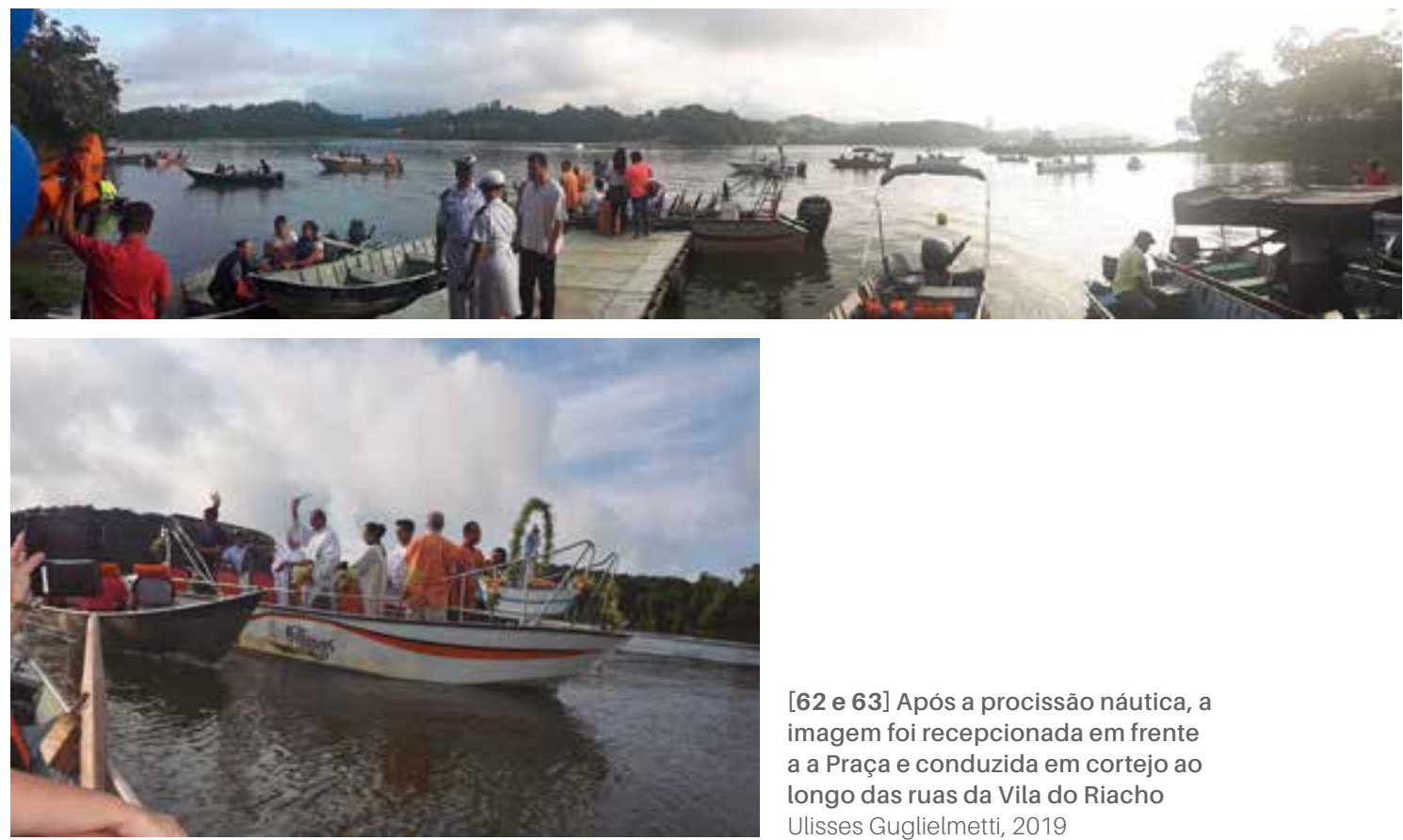

[62 e 63] Após a procissão náutica, a imagem foi recepcionada em frente a a Praça e conduzida em cortejo ao longo das ruas da Vila do Riacho Ulisses Guglielmetti, 2019
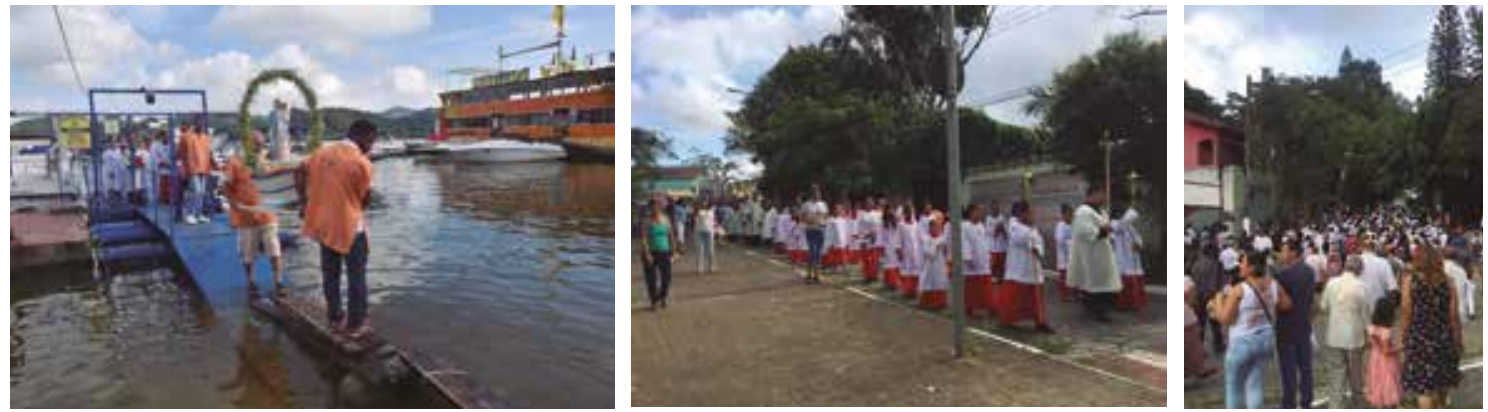

[64 a 66] Em seguida a imagem de Nossa Senhora foi levada à Paróquia São João Batista, para celebração da Santa Missa, presidida pelo pároco e co-celebrada pelo vigário. Ulisses Guglielmetti, 2019

Carolina Gimenez, 2019 

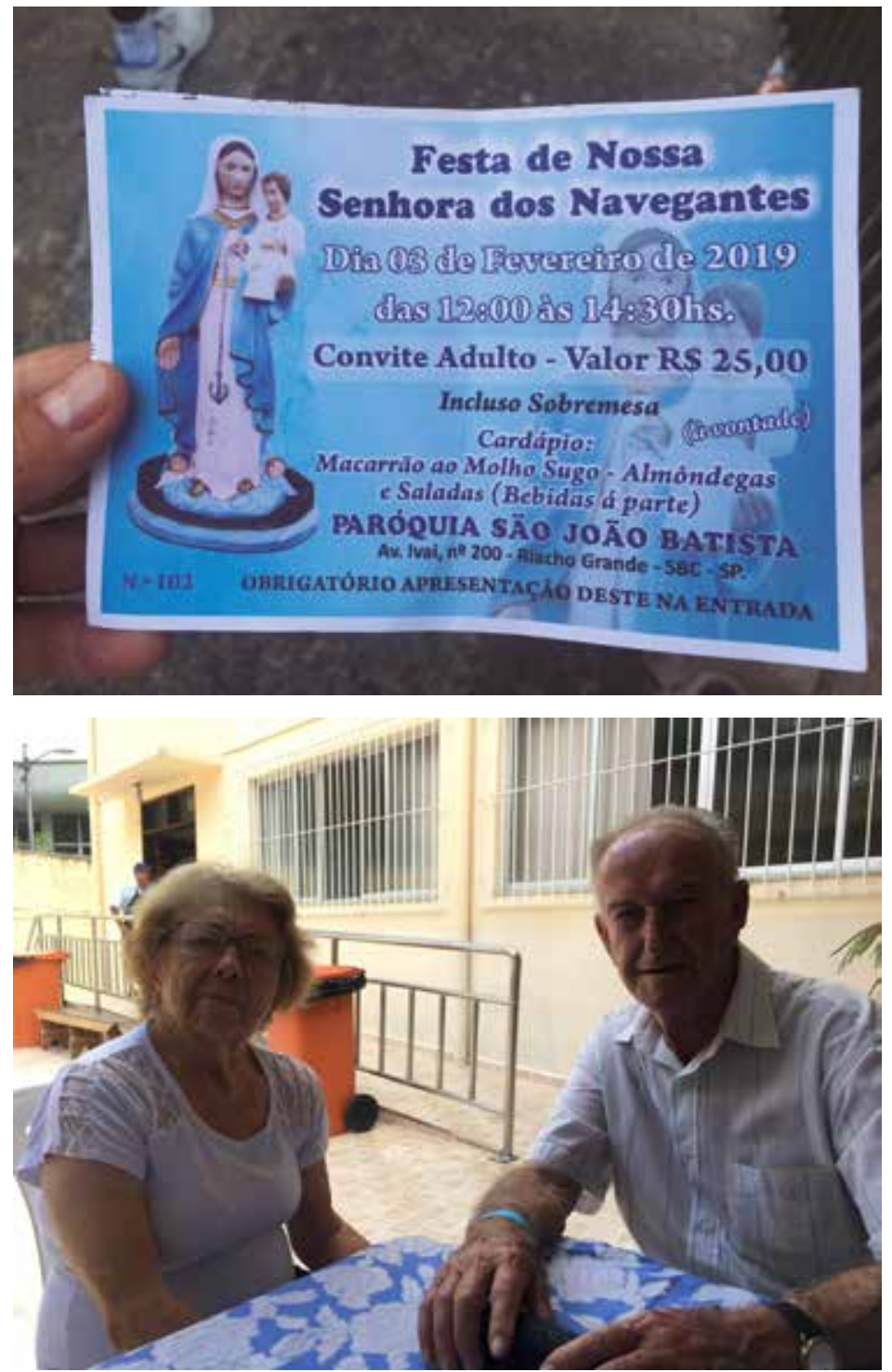

[67 e 68] Ao fim da missa, os fiéis e pessoas que acompanhavam o evento desde de manhã aguardavam ansiosamente o início do almoço festivo. Realizado atrás da igreja, uma quantidade grande de mulheres estava na cozinha da paróquia terminando os preparativos. Todos ali se conheciam, e eu fui apresentada para outras famílias de colonos italianos que frequentavam a festa desde as primeiras realizações. Servia-se vinho da família Rocco, que produz vinho artesanal no Riacho, tocava-se chorinho na banda de música ao vivo e circulava-se entre gente do pedaço. $\mathrm{Na}$ foto, o convite para o almoço e na sequência Leli e esposa. Carolina Gimenez, 2019 


\section{Cantinho do Céu}

A primeira visita que fiz ao Parque Cantinho do Céu em outubro de 2018 foi agendada com Ferruge após contato com a arquiteta Melissa Matsunaga, que sugeriu que o mesmo seria a ponte para outros contatos dentro do bairro. Historiador de formação, Ferruge, como é chamado, foi registrado como Adolfo Duarte, tem 37 anos, 29 deles vividos no bairro. Nosso primeiro encontro aconteceu durante uma oficina de marcenaria da Unigraja ${ }^{93}$ que ocorria na mesa de pingue pongue em frente à Billings, que considerei um ritual de passagem para minha entrada naquele pedaço, como já descrito no capítulo anterior.

Sem conhecer a região e em qual situação estaria o Parque passados 8 anos após sua inauguração procurei me informar com meu anfitrião se haveria algum cuidado que eu deveria tomar já que estaria sozinha. Ele me alertou para a existência de algumas "biqueiras" 94 e para o fato de haver uso corriqueiro de drogas leves tidas como ilegais, mas que se eu não tirasse fotos nem de uma coisa nem de outra, não haveria razões para preocupação.

Minha lembrança do bairro ainda estava vinculada às visitas que havia feito como estudante de Graduação em 2008, ocasião em que fui conhecer o CEU (Centro Educacional Unificado) Navegantes, um dos primeiro marcos urbanos no complexo. Alexandre Delijaicov, um dos autores do projeto,

93. Unigraja é a Universidade Livre do Grajaú. Trata-se de uma iniciativa dos vários coletivos que atuam na região para a formação de jovens estudantes da periferia. Nas palavras de Tim não é verdadeiramente uma Universidade Livre, nos moldes de outras Universidades, mas uma iniciativa do que chamou "nois por nois", ou seja, pensar a periferia através do olhar de quem reside nela. Durante o período da pesquisa pude acompanhar algumas atividades e a feira de encerramento do semestre, cujos registros aparecem no decorrer da dissertação.

94. Nome dado ao ponto de venda de drogas ligado ao crime organizado. relata ${ }^{95}$ que no terreno desapropriado para a construção daquela Unidade do CEU, haviam pessoas morando em situação muito precária:

"Quando fomos ver os terrenos do CEUs que seriam desapropriados, ao chegar na chácara onde seria implantado o CEU Navegantes, no Cantinho do Céu, encontramos pessoas naquele talvegue que moravam dentro de caixas de papelão de refrigerador, como se estivessem numa casinha de cachorro, dormindo numa toca"

A dissertação da arquiteta Melissa, principal fonte antes da primeira visita, também apontava para um desfecho melancólico do processo de implantação do Parque, resultando em muitas pessoas descontentes pelos deslocamentos forçados e o profundo desapontamento da principal liderança, Dona Vera, que havia sido fundamental na interlocução entre os técnicos e os moradores, e que ao fim acabou se deprimindo pois nutrira a expectativa de se tornar a gestora do espaço, fato que nunca ocorreu ${ }^{96}$. O que eu encontraria pela frente?

Para minha surpresa o Parque pareceu, na primeira visita, um "oásis" no meio daquela paisagem tomada por certa monotonia, resultado de um processo em que o esforço de cada família em aproveitar ao máximo os poucos recursos disponíveis para construir a morada, resulta, invariavelmente, numa volumetria constituída do empilhamento de blocos cerâmicos sob lajes de concreto, multiplicando três, às vezes quatro vezes a exata área do lote em que

95. Relato feito durante sua arguição no exame de qualificação deste trabalho.

96. Melissa conta que essa expectativa foi criada pela Dona Vera, que se sentia "dona" do Parque e que em alguns momentos havia feito solicitaçōes incompatíveis com a finalidade pública do mesmo, como por exemplo cercar a quadra de futebol e ser guardiã da chave que abriria a mesma. 

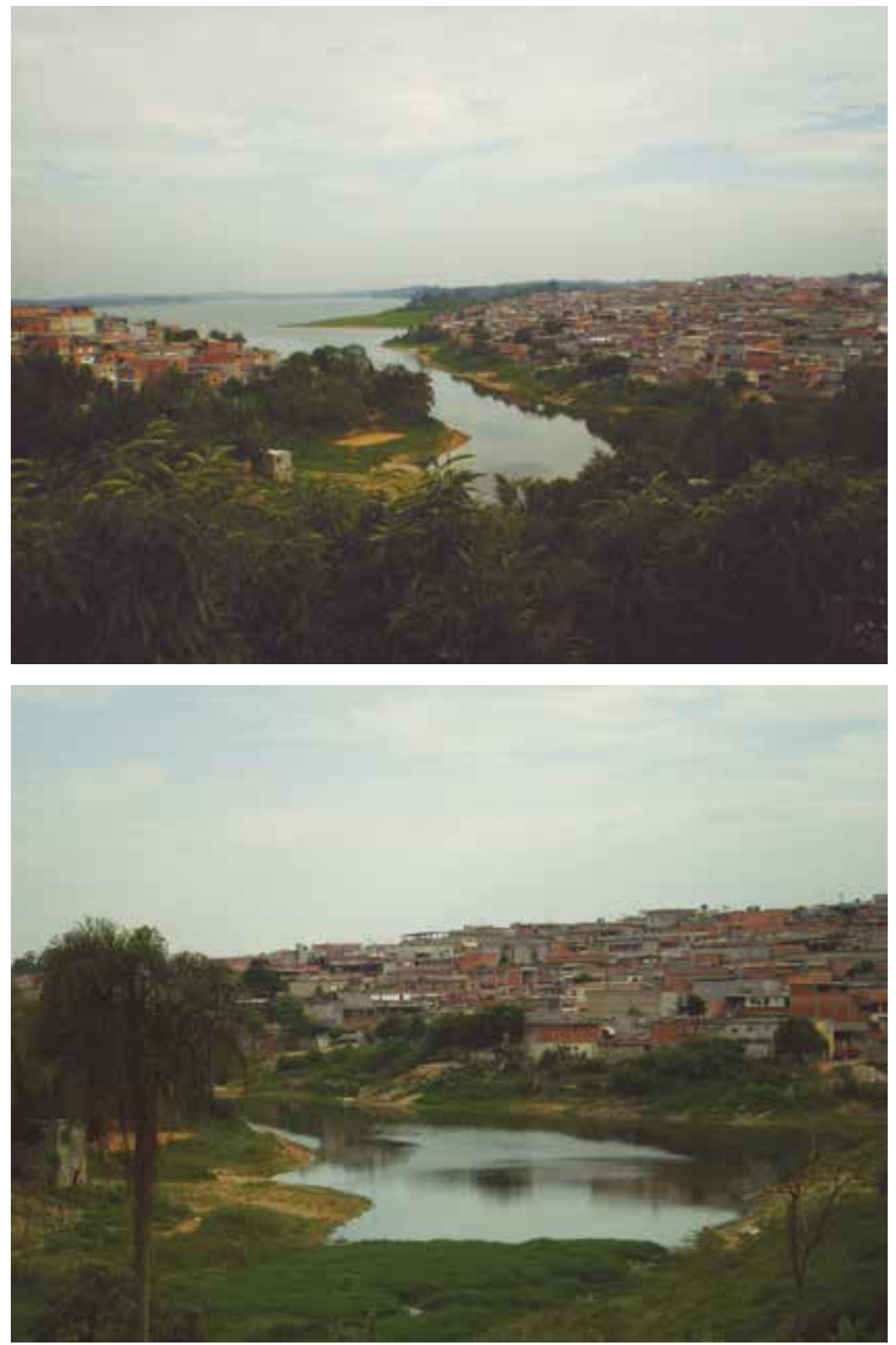

[69 e 70] Vista do Ceu Navegantes,

Carolina Gimenez, 2008 

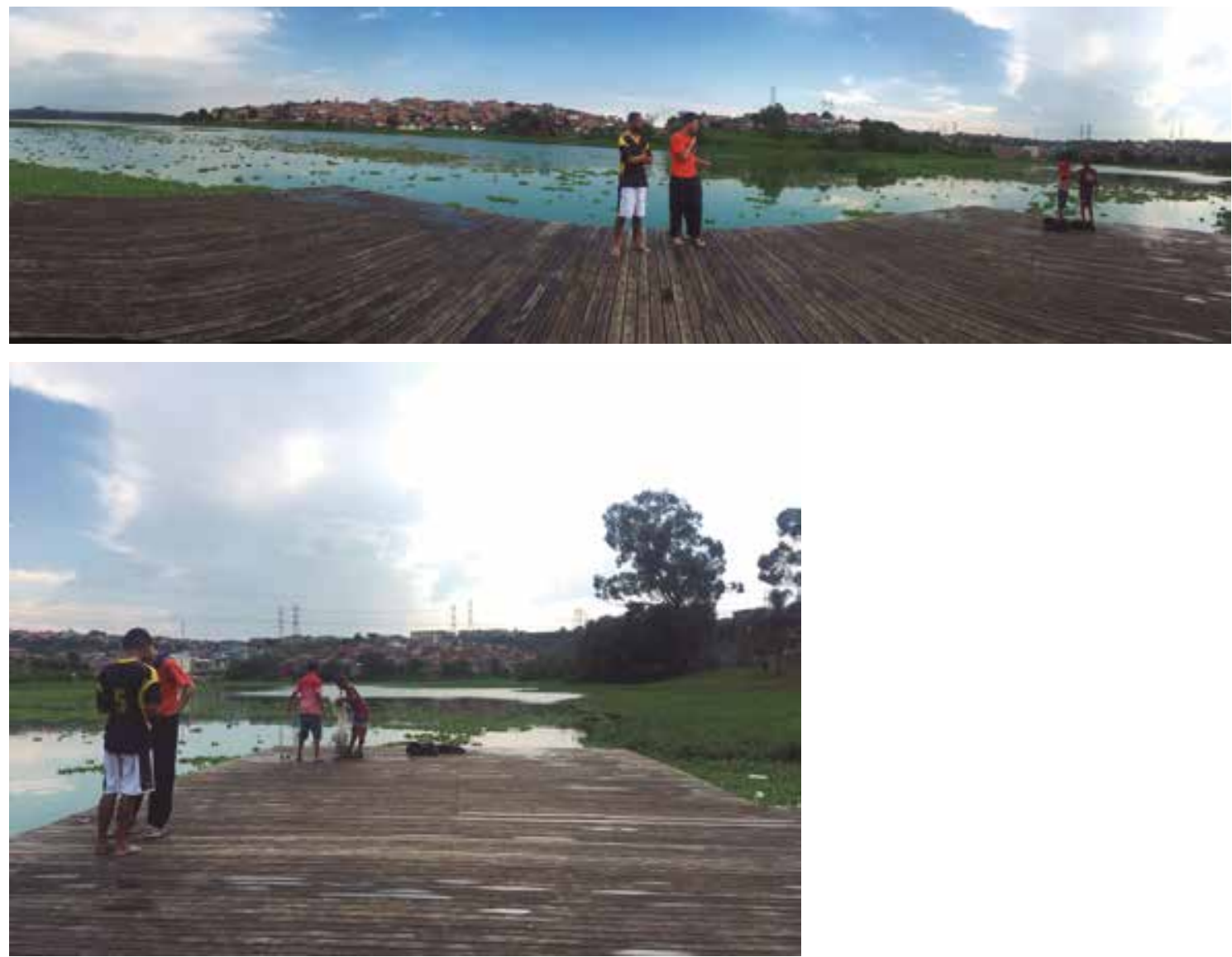

[71 e 72] Meninos soltam tarrafa e conversam no deck Carolina Gimenez, 2018 
se implantam.

Nesse dia fui recebida por uma brisa fresca e úmida, que depois vim a saber que era bastante comum às tardes na beira da represa, pois nas palavras de Ferruge: "de manhã, quando venta, vem o ar seco e quente de São Paulo, à tarde, vem sempre o ar fresco e úmido do litoral". Esse ar fresco e úmido que me recepcionou me possibilitou apreender a paisagem da represa em horizontes mais amplos que àqueles sugeridos pelo trajeto, em que aparentemente predomina a periferia cinzenta e homogênea.

Ao conversar com Ferruge uma das primeiras coisas que escuto, e que depois se repetiria em outras conversas com outras pessoas é que o Parque havia mudado por completo a relação das pessoas com a represa. "Catarse", "Superação do trauma", "estouro da boiada" foram os termos que ele usou para descrever a inauguração do primeiro trecho, onde está implantada a pista de skate e a quadra de futebol, e que "até aquilo entrar na normalidade, precisou de muita bomba de efeito moral, porque todo dia tinha festa, pancadão, multidão e confusão". Ao mesmo tempo que o processo de construção havia sido dolorido e traumático, gerando muita insegurança e incertezas entre os moradores, e que segundo outro vivenciador, Tim, havia a promessa de alguns de que nunca usariam aquele espaço, quando foi inaugurado, o Parque passou a ser frequentado intensamente tanto por moradores do pedaço como de outras localidades.

A relação dos vivenciadores da represa no Cantinho do Céu tem a presença de alguns componentes que se repetem: a mudança trazida pelo Parque Linear, a represa no lugar da aventura e do perigo e as mortes frequentes por afogamento. São esses os temas trazidos por Enivo quando inicio a entrevista perguntado "Qual sua relação com a represa".
"ENIVO. Eu posso falar a minha relação com a represa. Eu morei há cerca de $1 \mathrm{~km}$ da represa, morava no Jardim Eliana, perto de vários braços da represa...então eu morava ali na frente do campo de futebol, na Rua Clarissa, onde eu cresci, e dava para ir sempre a pé para a represa (...) e eu tenho muitas memórias lá do meu tio, Walter, que sempre me levava para passear nos braços da represa, tanto na primeira balsa... andava de balsa, ali perto da Ecoativa, projeto que o Tim está envolvido, mas na verdade uma amiga da minha mãe morava lá e o pai dessa amiga trabalhava lá, era balseiro, então eles moravam no Bororé. Então eu tenho essas memórias de passar lá, tem uma igrejinha lá na frente, aquela cruz...são coisas que eu tenho a memória muito marcante. É nessa parte da represa também que em 2003 a gente perdeu o Niggaz, que era um artista muito importante para a gente. Ele faleceu ali nas águas, em 2003, afogado. Então também se torna marcante esse lugar, que deu origem em 2007 ao "Imargem"...".

CAROLINA. O imargem é uma forma elaboração também, certo?

ENIVO.: Sim, e então, isso ali na região da balsa, e tem o outro braço que se pegar o arco de onde eu morava, as mesmas distâncias, que é o Canal do Cocaia, que já era um lugar que eu sempre via como muito degradado, a construção lá foi muito avançada, avançaram muito para as beiras, então sempre tinha bicho morto, cavalo morto, gente morta. Ali embaixo era uma rua mais densa. $O$ Cocaia mesmo no final dos anos 80 e começo dos anos 90 era realmente... e que era onde meu tio me levava ali. Cocaia, Cipramar, Lago Azul, o que é hoje é o Cantinho do Céu, o Parque Linear, ali no Lagoa Azul meu tio me levava para passear na floresta. E lá era floresta, não existia casa nenhuma, era mata fechada. 

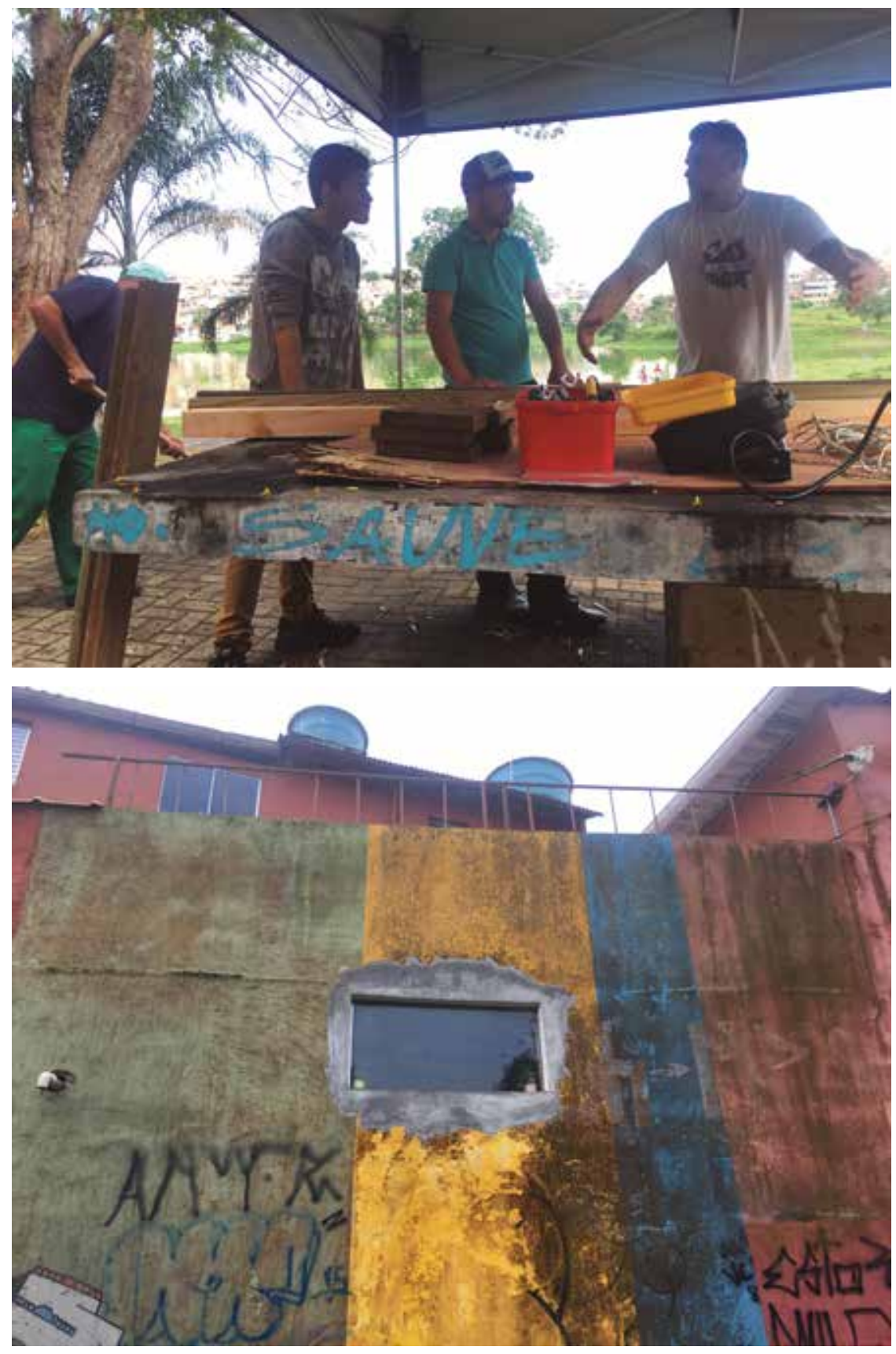

[73 e 74] Oficina de marcenaria no Parque e Janela da casa Carolina Gimenez, 2018 
CAROLINA. E como entra o Parque Linear nesse história?

ENIVO: Tem uns filmes também para te mostrar, um vídeo, bem bonito. Com eu e o Mmoneis, e tem a construção desse painel no Parque Linear. Tem cenas da represa, é bem bacana. Então é essa a ligação que eu tenho, sabe, essa coisa com a natureza. E ai construíram um lugar lindo. Hoje é um lugar limpo, um lugar lindo, um lugar maravilhoso, eu tenho orgulho de levar as pessoas, estrangeiros, pessoas que eu admiro, artistas, principalmente ali para o Parque Linear.

Durante a oficina de marcenaria, Ferruge me conta que o objetivo era que os estudantes conseguissem construir as barracas para serem usadas na feira de encerramento do semestre que aconteceria ao final de dezembro na "curva do vento", nome dado ao mirante de onde se vê o rodoanel. Pergunto por que do nome, e descubro que ali é "onde o vento faz a curva", que remete tanto ao fato de estar em um lugar distante de tudo, mas também ao fato de receber as rajadas de vento que vêm do corpo central da represa. A oficina, com duração de dois dias, teve participação dos alunos selecionados para as atividades do Unigraja e aconteceu no parque próximo ao pier. O local fora escolhido por ter uma mesa fixa de concreto projetada para ser usada como mesa de ping-pongue, mas que servia perfeitamente a vários propósitos. Próximo a sede de outro projeto do Ferruge, "Meninos da Billings", que promove vivências náuticas na represa, esse lugar acabou se configurando o meu pedaço, de onde partiram as minhas observações em razão da possibilidade das pessoas poderem estar em relação direta com as águas através do pier.

Enquanto eu acompanhava o desenrolar da oficina pude observar dois meninos de aproxima- damente 10 anos treinando o lançamento da tarrafa ao lado de outros jovens, que depois vim a saber que estavam "cabulando" aula para ficar no Parque. Na oficina, dois alunos estiveram presentes: Symon e Pedro. Aproveitei a presença dos dois para perguntar sobre a relação deles com o espaço, como enxergavam a represa e o Parque. "Da hora tio", foi a resposta que ouvi de Pedro, que embora dissesse que se tivesse oportunidade de sair do bairro, sairia, mas que gostava de passar o tempo ali, especial-

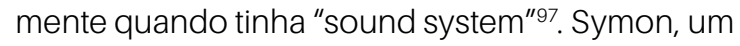
pouco mais reservado apenas sorriu.

Atrás da mesa onde ocorria a oficina me deparei com uma situação intrigante: no meio da pintura do antigo mural desenvolvido à época de implantação, uma janela recortava a empena cega da casa divisa com o Parque. O painel estava ali atrapalhando a vista do morador, que sem muito pudor, quis ter a paisagem da represa dentro da sua própria casa.

O tema do painel foi apresentado po Marcos Boldarini na entrevista, que relatou ter havido um certo "ruído" com os coletivos de artistas do Grajaú. Houve uma tentativa de trabalharem juntos em outro trecho do Parque, que não vingou por divergências sobre o valor a ser pago para os artistas, o que gerou um desconforto entre as partes envolvidas:

MARCOS BOLDARINI.: "Tentamos um diálogo. Fizemos algumas imagens de uma viela, chamei os caras aqui no escritório e falei : "Olha, a gente tem essa oportunidade para trabalhar juntos, eu tenho essa percepção para o lugar, a gente têm duas escalas de muro, uma mais alta e essas mais baixas, eu quero saber se vocês topam, eu tenho uma ideia. Eu queria que o azul do céu entrasse para a viela

97. Jargão usado para as noites em que jovens levam aparelhos de som para o Parque para passar a noite escutando música com os amigos. 


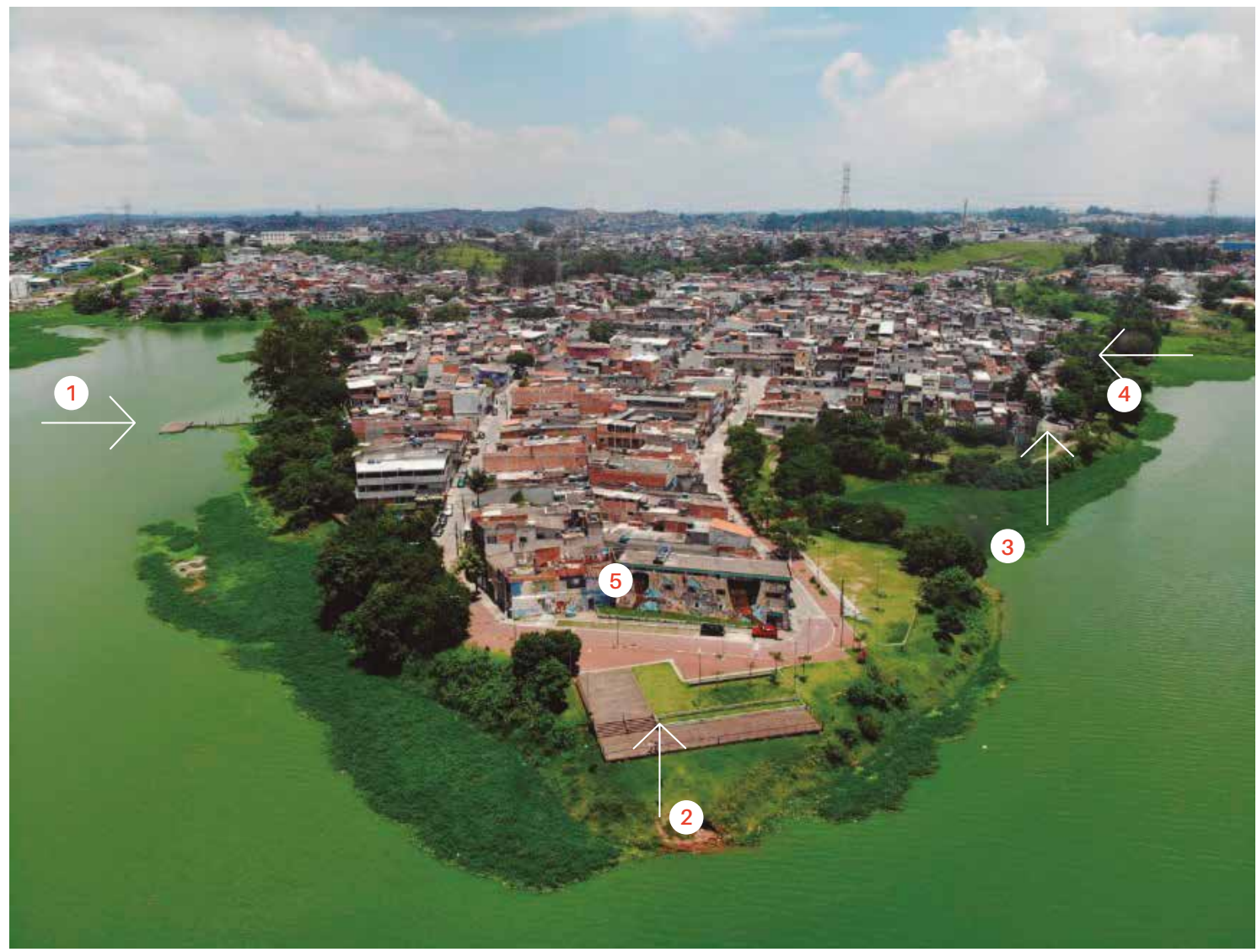

[75] Pedaços do pedaço

Vôo drone

Michel Gubeissi, Carolina Gimenez, 2018

1. Pier ou $T$

2. Curva do vento

3. Ponte

4. Arco

5. Painel de envio 
nessas paredes mais altas, laterais de casa de três, quatro andares, então num dia de céu muito azul essa coisa vai formar um túnel na medida que você olha de cima ou de baixo para cima. Isso que está na altura do olhar a gente podia definir um pouco para cada artista. Não conseguiram organizar isso e a resposta que veio para a gente era assim: "Ó, não dá para organizar porque os caras vão lá, são artistas e fazem o que querem". E eu falei: "Bom, então vocês façam sozinhos, vocês vieram pedir apoio, eu tentei organizar", veio um primeiro um orçamento que era um despautério.

Para Marcos Boldarini o valor era incompatível com o trabalho, para o coletivo Imargem aquela era uma oportunidade de valorizar os artistas locais remunerando-os bem, segundo Tim:

"A gente mandou um orçamento alto, eu tenho consciência, mas tinha um propósito, queriamos valorizar a potência dos artistas daqui. Mas eu entendo o lado de lá também, poderíamos ter trabalhado juntos"

Na minha opinião, a apropriação daquelas empenas seria naturalmente uma das primeiras coisas a serem alteradas do projeto, como de fato foi. Além das inúmeras intervenções que foram acontecendo de forma espontânea sobre o painel, houve em 2014 um projeto chamado "Transformações" que por um período de quase 12 meses capitaneou intervenções artísticas em diferentes locais do Grajaú. Entre as ações, destacamos uma delas em particular: o Painel do artista Enivo na curva do vento.

O espaço em frente ao painel, muito utilizado pelas famílias aos finais de semana também é chamado de "a câmera", apelido dado em razão de uma antiga câmera de monitoramento da Guarda
Civil Metropolitana (GCM) que depois foi arrancada. Deste trecho do Parque ando em direção ao "Arco", um suporte metálico originalmente projetado para exibição de filmes mas que acabou ficando apenas como um elemento escultórico, pois a projeção de filmes aconteceu apenas durante os primeiros meses de utilização do Parque. Ao andar em direção ao "arco" é fácil captar uma certa tensão um pouco antes da "ponte", pelo fato de ser o local onde a "lojinha" ou "biqueira" é aberta, razão pela qual meus registros foram menos frequentes nesse lugar.

Os diferentes públicos no parque flutuam de acordo com horários e dias da semana: durante a semana, de manhã cedo antes de ir para o trabalho ou antes que o sol fique muito intenso, homens e mulheres mais velhos fazem caminhadas e exercícios até aproximadamente 9h00. São substituídos por crianças, principalmente meninos, que antes do almoço ficam conversando no pier, jogando bola na quadra de futebol ou andando de "carrinho" na pista de skate. À tarde, aparecem alguns grupos de adolescentes, "cabulando" aula e jovens adultos que se reúnem em grupo às vezes para "causar", às vezes para testar manobras de parkour, às vezes para tocar uma música, muitas vezes somente para passar o tempo e conversar com os amigos. Vários moradores se aproveitaram da situação de contiguidade de suas casas junto ao Parque e abriram pontos de comércio de bebidas e comidas que são vendidas para quem estiver por ali. No fim do dia, esse comércio é muito utilizado por homens, voltando do trabalho ou não, que vão para o Parque para se encontrar, beber e se divertir. Aos finais de semana esse movimento vai até amanhecer.

Essa rotina às vezes é interrompida quando o Parque recebe eventos, os mais variados possiveis. Durante o período em que estive no campo, destaco dois: O festival Red Bull Amaphiko e a Feira de Encerramento do ano da Unigraja. Ambos eventos reuniram pessoas de vários pedaços, vinculando o 
Parque linear a um circuito de lazer maior, ampliando assim suas bordas.

A feira aconteceu no dia 09 de Dezembro e contou com a participação de dez coletivos. Trata-se de uma rede de contatos que naturalmente extrapola aquele pedaço, abrangendo universitários, veganos, permacultores e interessados em geral, além daqueles que estavam diretamente relacionados as atividades do unigraja.

Por ser um Parque linear e por ter uso intenso por um período de horas tão prolongado, é difícil captar todos esses movimentos numa primeira visita, mas estar no parque é como estar imersa na brisa fresca no meio de um entorno árido. Essa dicotomia brisa e aridez tem contornos que descreveremos a seguir.

\section{Homens e Mulheres}

O parque está ocupado, é uma tarde de terça-feira ainda durante a vigência das férias escolares e o píer, ou $\mathrm{T}^{98}$ como é chamado pelos moradores, está em pleno uso por grupos de meninos que se revezam fazendo acrobacias ao se jogarem na água. Há nesse horário, como em outros dias, uma predominância de meninos e homens usufruindo do parque, que me levanta questões sobre o papel das mulheres naquele espaço, e que em outros momentos, por ser a única mulher presente, me dá certa insegurança. Embora a presença feminina seja menos frequente fisicamente no parque, e aconteça com mais frequência no período da manhã, ela foi fundamental nas atuações por melhorias no bairro e nas articulações durante o período de execução das obras, como aponta MATSUNAGA (2005). Quando questionado sobre uma possivel diferença na participação de meninos e meninas no espaço

98. O T remete a forma como o pier foi projetado. público, Ferruge explica que se a visibilidade das mulheres no parque é menor, por outro lado são elas que põe a mão na massa:

"FERRUGE.Isso, ai domingo eu passei ali e vi os equipamentos (de ginástica) todos enferrujados, mas chumbados, instalados na rua e eu me perguntei: 'Quem foi que fez isso?', tá tudo ferrado, tudo quebrado, enferrujado, mas funcionando. Ai eu parei o carro e perguntei: 'Quem foi que instalou isso aqui?', tinha umas seis mulheres e elas falaram assim: 'A gente', e eu: 'Como assim?', e elas: 'Nós aqui', e eu: 'Mas vocês contrataram um serralheiro?' e responderam: 'Não moço, nós que puxamos com a corda', elas cavaram, chumbaram, viraram concreto, você precisa ver, um negócio muito louco, elas fizeram a academia ali.

CAROLINA. Estou vendo ali

FERRUGE. Está lá, elas resgataram os negócios no fundo da represa, mano. Umas seis mulheres e um monte de meninas adolescentes, algumas mulheres mais idosas...O nome 'Meninos das Billings', não tem mais meninos, hoje é Meninxs com x, porque muitas meninas participam também do 'remada na quebrada' e inclusive tem protagonistas mulheres. A Cristina Lacerda é uma professora que fez uma pesquisa do óleo usado que ia para a represa e transforma em biodiesel, tem muita mulher que põe a mão na massa, na verdade é a maioria, no natal a gente fez a ação de distribuição dos brinquedos e todas as voluntárias eram mulheres, eram as mães, então tem uma participação. Aí uma das mulheres cobraram: 'Por que meninos da Billings?' e tem todo um contexto, na época eu fiz uma referência ao meu filho (que faleceu), Miguel, por isso que foi 'Meninos da Billings', foi uma lembrança, mas que na verdade contempla à todos. 


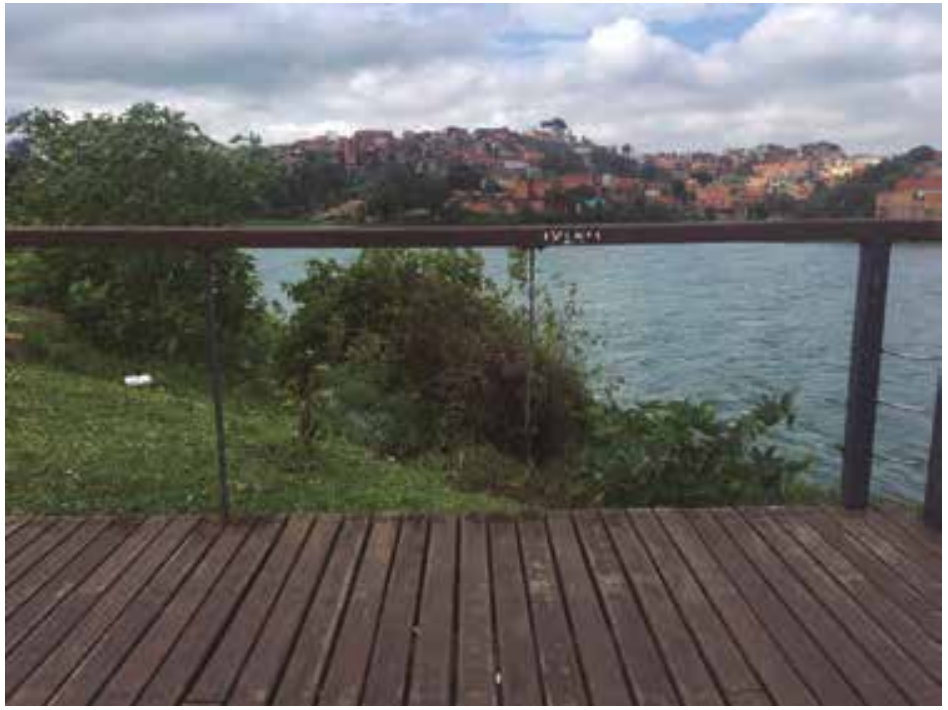

[76] Guarda corpo vandalizado Carolina Gimenez, 2019

\section{Manutenção}

No mesmo dia em que eu aguardava no mirante para realizar uma entrevista, e que acabou por acontecer alguns dias depois, conheci Rodrigo e Bruno ${ }^{99}$. O encontro, resultado de uma casualidade, pois o que havia me levado aquele dia ao Parque era a entrevista agendada, apontou alguns elementos chave sobre a manutenção e segurança dos espaços. Ao ouvir a conversa sobre mortes na água, assunto tão presente nas entrevistas que realizei, me aproximei, me apresentei, falando que aguardava Ferruge ${ }^{100}$ para uma entrevista, conhecido de ambos.

As queixas apresentadas diziam respeito principalmente a dificuldade em manter o Parque em condições adequadas. Rodrigo criticava tanto os usuários, que para ele não tem consciência, jogam lixo em qualquer lugar, como problemas relacionados a conservação dos decks e guarda-corpos. Ele me pergunta "Como a gente vai manter aqui o

99. Essa conversa aconteceu no dia 29 de janeiro no mirante do Parque Linear e não foi gravada.

100. Foram vários encontros que aconteceram durante a pesquisa, sendo um desses encontros com horário marcado e audio gravado deck? Tem coisa que a gente, sozinho, dentro da comunidade, não tem como dar conta". Eu concordo.

Acredito que os decks e guarda-corpos são dois elementos críticos nas condições que foram implantados. A opção adotada para os guarda-corpos em cabos metálicos para fazer a proteção no vão entre os parapeitos e pisos me parece inadequada. Embora esteticamente delicada, não apresenta durabilidade alguma em situações de uso intenso, sendo mais adequado para usos bastante restritos. Para além da questão da delicadeza da solução, os cabos são retiráveis com instrumentos simples de corte, o que facilita bastante a vandalização. O resultado, no parque, é que nenhum guarda-corpo está íntegro, gerando situações inseguras, especialmente para crianças pequenas.

Enquanto conversava com Rodrigo, que estava com o filho pequeno de 2 anos, tive uma breve demonstração de como esse detalhe interfere diretamente na relação dos pais de crianças pequenas com o espaço do mirante: é preciso atenção máxima em tempo integral.

Em relação a utilização dos decks de madeira, partido adotado para diversas situações de projeto 

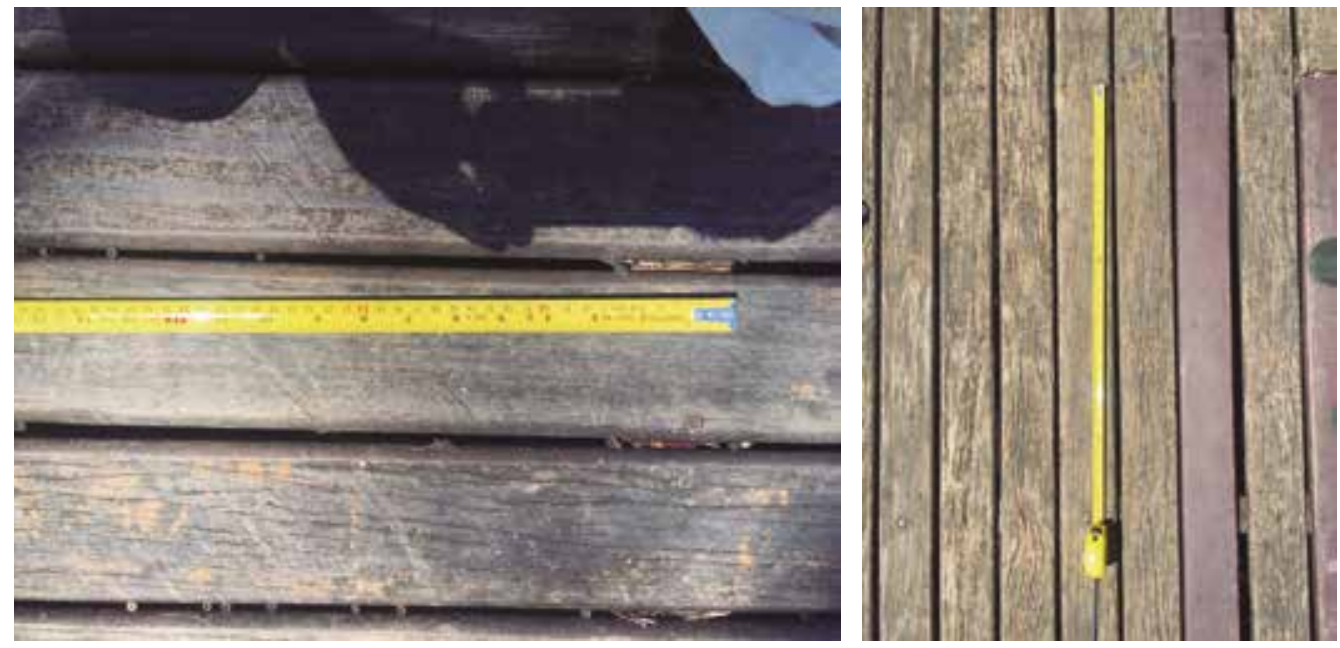

[77 e 78] Fotos do Píer e Mirante: Decks Fornecidospela empresa PierGlass, também responsável pela consultoria ao escritório de Arquitetura no detalhamento. No pier são vãos de $70 \mathrm{~cm}$ com madeiras de $2 \mathrm{~cm}$ de espessura. Numa situação de demanda intensa de uso, exposição ao tempo, inexistência de manutenção, são várias as madeiras que estão apresentando sinais de fadiga, algumas delas tendo sido substituídas aleatoriamente, outras estão se rompendo. No mirante o vão é de $60 \mathrm{~cm}$, que embora seja admissível, poderia ter maior durabilidade se tivesse apoios mais frequentes, espessuras maiores nas seções e manutenção constante.

Carolina Gimenez, 2019

no percurso do Parque Linear, embora exista um ganho significativo em relação a permeabilidade do platôs e possibilidade de utilização de encostas e terrenos íngremes com pouca movimentação de terra, a avaliação é que passados 8 anos de implantação do projeto a maior parte deles está apresentando problemas sérios de resistência e conservação. A solução adotada, bastante adequada para a implantação em APP (área de proteção permanente), poderia ter sua durabilidade estendida caso o arranjo estrutural dos decks fosse outro, adotando-se estruturas mais robustas e com vãos menores que certamente iriam demandar menos esforço de flexão nas peças de madeira, aumentando a vida útil das mesmas.

Rodrigo e Bruno sentem falta de uma sede, símbolo da presença do poder público, que deveria servir tanto como ponto de apoio para atividades culturais, como o de ser uma referência para a molecada. Rodrigo fala: "a molecada precisando de exemplos para seguir e o exemplo é o funk ostentação". Apontam para imóvel onde está o painel do grafiteiro Enivo, dá frente para o mirante e falam: "seria uma bela sede para o parque". Citam a falta de oportunidades no bairro e a facilidade em ver o mundo do crime como uma saída para a vida.

Ferruge por outro lado acredita que a sede viraria um "ponto de lamentações":

CAROLINA. Você sente falta de uma sede aqui, para o parque?

FERRUGE.Não, porque infelizmente na periferia existe essa cultura do assistencialismo, essa questão de "Ah, é culpa do fulano, fala com o fulano", para você ter uma noção, quando eu assumi o cargo, todos do bairro achavam que eu vireio 'presidente' do bairro, tudo que era problema de energia, o gás da casa da mulher faltou, era "fala com o Ferruge'(...) "Arrombaram lá, roubaram lá no parque, então é você"? Não sou eu, é polícia militar, então esse é 


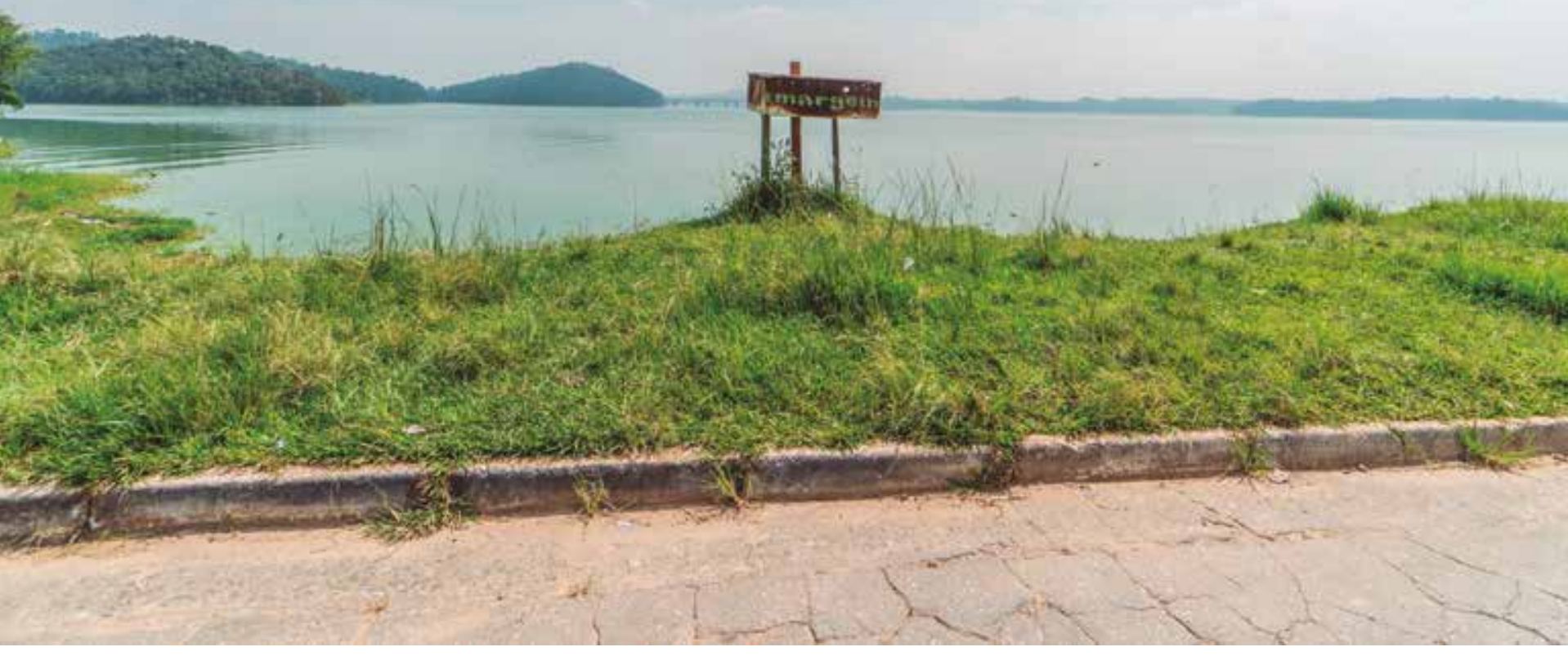

[79] Intervenção artística do grupo Imargem na Ilha do Bororé. A foto

foi tirada próxima a chegada da balsa de São Bernardo do Campo, olhando em direção ao rodoanel Carolina Gimenez, 2018 

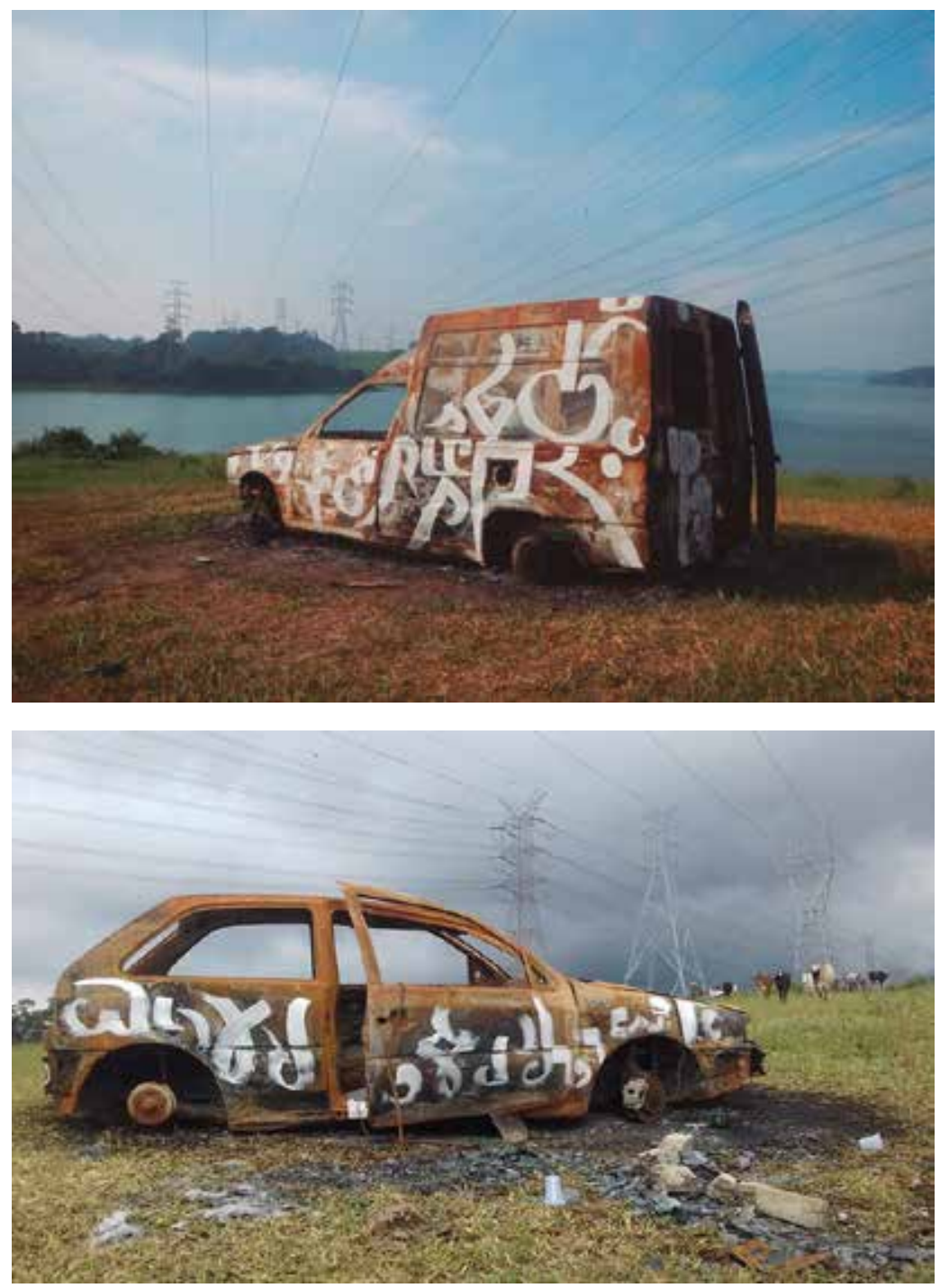

[80 e 81] Intervenções

artísticas em carcaças

Tim, 2017 
um problema, se você tem uma sede isso acaba virando um ponto de lamentações, isso não os impede de me encontrarem, a base dos guardas tem meu telefone disponivel, eles são autorizados a passar meu telefone para qualquer pessoa, porque eu quero saber o que está acontecendo, eu quero entender, se a gente vai resolver ou não já é outra história.

\section{Tim e o imargem}

Tim é envolvido com vários coletivos e fundador, junto com o irmão, do coletivo imargem. O jogo de palavras imagem e margem denota uma operação de poetização para a margem, tanto da represa como da sociedade. O grupo começou a se formar ainda na época em que Niggaz era vivo, e se autodenominavam agentes marginais, porém ainda não agiam em formato de coletivo, com um nome e uma organização por trás. A ideia era colocar a "quebrada" em foco, através das suas palavras com a cultura hip-hop em suas várias vertentes: rap, grafitti, estêncil, etc.

Na primeira conversa que tive com Tim, na casa ecoativa na ilha do Bororé, ele me falou uma frase que depois retomou na nossa entrevista: "o residencial dos Lagos era um não lugar. Agora é algum lugar.".

\section{O perigo mora ao lado}

Bruno e Rodrigo já haviam me dito: "Tá morrendo um monte de menino aí na represa", "pois é rapaz, e morre do quê?" "quando não é desova, é os meninos que morrem afogados". Comento que esse assunto das mortes havia aparecido em outras conversas e Rodrigo repete a mesma versão que eu já havia escutado em outras ocasiões: a ida a represa não é consentida pelos pais, mas todos os meninos vão.
Nesse mesmo dia, um pouco antes ouvi uma conversa entre dois meninos que confirmava essa versão, um falava para o outro: "se a gente chegar molhado a mãe vai matar a gente, o que a gente faz?". Essa mesma versão apareceu na conversa com Tim, algumas semanas antes, quando ele afirmou que ia para represa sem a mãe saber e lembrou da perda de um amigo querido para a Represa em 2003.

"TIM: A gente desde pequeno se acostuma ao perigo da represa, que também é aventura. Todo moleque já apanhou em casa porque foi para a represa sem avisar, porque mesmo sem contar, depois aparecem aquelas manchas brancas no corpo e já não tem como esconder que entrou na água... aí a mãe vinha ralhar...Foi numa dessas que perdemos o Niggaz. Já éramos adultos, mas ainda gostávamos de desbravar por aí, buscávamos os lugares escondidos, de difícil acesso, que às vezes passavam por um terreno de um e de outro. Na noite que ele morreu tava todo mundo junto perto da represa e cada um foi indo embora aos poucos e ele foi ficando. Não sabemos se ele caiu, se alguém empurrou, porque a gente passava ali pelas propriedades e tal, ou se ele já tinha tomado algumas já, tudo isso pode ter acontecido".

A memória de ver bombeiros passando na água está associada as mortes na represa, e isso comparece na fala de Enivo também:

ENIVO: Todo mundo ali eu conheço desde criança, então é uma coisa linda. No dia que a gente foi andar de skate, é coisa de emocionar mesmo, de juntar todos os amigos e relembrar... Aquela nostalgia. Então, é um local onde eu me sinto em casa, por isso, que eu propago o Grajaú. Aquela região, aquelas águas. Lembro que tanto no skate, quanto 


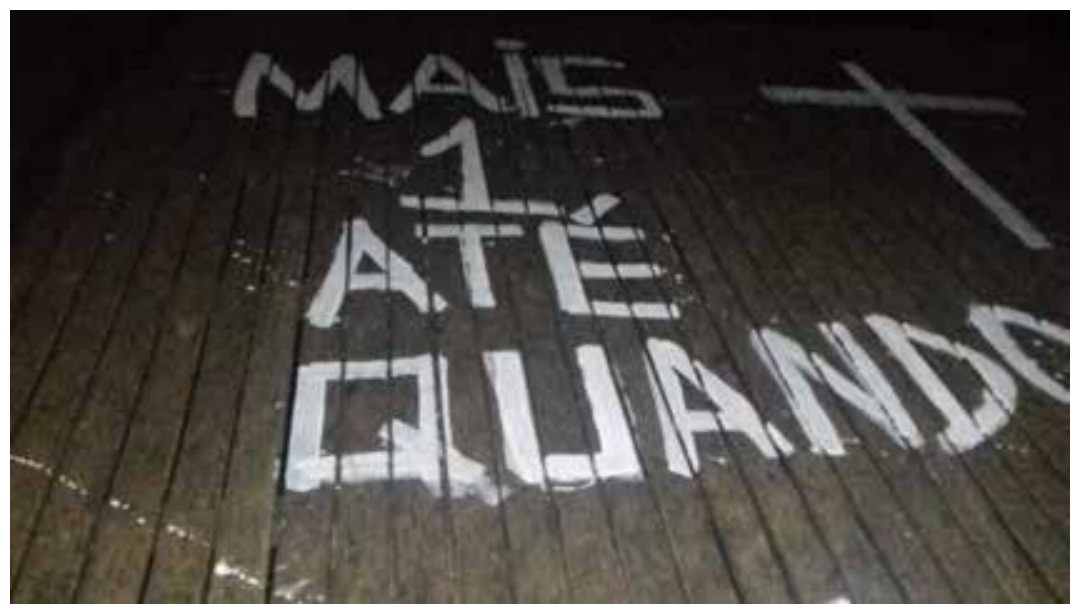

[82] Píer com inscrições dos moradores no dia 02.02.2019

Ferruge, 2019

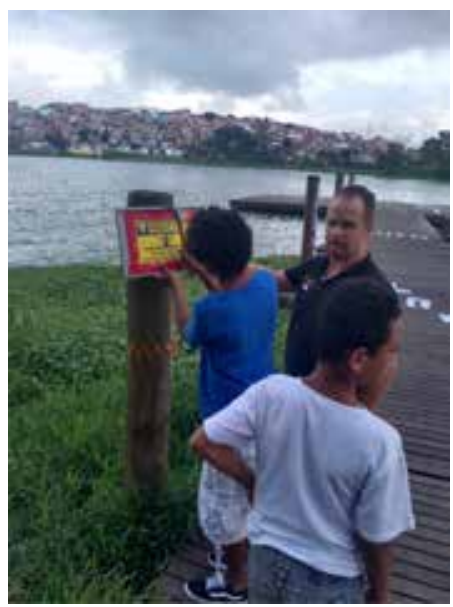

[83] Ferruge auxilia na instalação de placas alertando para risco de afogamento no deck em 03.02.2019 Autor desconhecido, 2019 na época que eu andava de patins, a gente descia ali a ladeira, e fazia isso dez vezes, porque descia, esperava a balsa, quando saia os carros a gente pegava a rabeira e subia tudo de novo. Eficava descendo e subindo, então, tem muita memória assim...

\section{CAROLINA: pegava rabeira da balsa?}

ENIVO: Não, da balsa não, dos carros. A gente ficava descendo e subindo, descendo e subindo, e sempre pegando esse fluxo. E tinha muito bombeiro passando também; morria gente demais, todo final de semana tinha morte. Ainda deve ter; não sei porque eu não frequento mais.

CAROLINA: É horrivel mesmo. No fim de semana passado, soube da morte de um garoto lá.

ENIVO: Tem, tem. Mas isso é direto. Morre muito. Já perdi amiguinho, o próprio Niggaz era muito jovem, tinha 20 anos. Toda semana, era muito bombeiro descendo, porque muita gente...

As fatalidades acontecem longe dos olhos dos adultos que geralmente ficam sabendo que os filhos estavam na represa quando a tragédia já aconteceu. "a mãe só vai dar conhecimento quando o corpo já tá boiando" diz Rodrigo. Pergunto se não há nenhum tipo de patrulha da marinha ou bombeiro, e recebo a seguinte resposta: "eles são muito eficientes e violentos para prender quem usa tarrafa, que agora é época de piracema, então eles só aparecem para dar esculacho". De todas as visitas a campo, eu vi o barco dos bombeiros apenas uma vez, e de passagem.

Quando questionado sobre essa problemática, Ferruge conta:

CAROLINA: E você acha que precisaria ter mais gente na equipe?

FERRUGE: Deveria aumentar a equipe de seguranças e deveria ter um ponto de apoio do corpo de bombeiros, não de uma empresa terceirizada e sim do corpo de bombeiros do Estado CAROLINA: Até pela questão de afogamento né? FERRUGE: Tem que ter um barco disponivel 24h para fazer "salvatagem", tem que ter uma casinha para o salva-vidas. Isso faz falta, você acaba legitimando o uso do pier, o cara vai ver que tem salva-vidas e vai ficar mais tranquilo. CAROLINA: Até porque o pier não tem guarda-cor- 
po né? Se vem uma criança correndo, cai na água FERRUGE: Já foi solicitado para que eu colocasse uma base aqui na frente do pier, mas quem tem condições de trabalhar aqui são os guardas, e os guardas são patrimoniais e não salva-vidas, o que eu fiz foi comprar um kit de "salvatagem", deixei bem claro aos moradores que existe esse kit lá na base, na guarita que é um colete salva-vidas, uma boia e um cabo de 15m, se alguém precisar é só correr lá e pegar.

Era uma questão de tempo para que um evento desses acontecesse no período em que a pesquisa se desenvolveu. No dia 02 de fevereiro, data comemorada tanto pela tradição cristã como pela tradição do candomblé, féis e simpatizantes celebram a Senhora dos Navegantes. Nesse dia, enquanto me preparava para acompanhar a procissão náutica e terrestre que aconteceria na manhã do dia seguinte no Riacho Grande, um menino de 15 anos morreu afogado no Cantinho do Céu. Daniel, que fora aluno do Ferruge, "Um menino de ouro" nas palavras do mesmo, foi brincar no pier no sábado à tarde e se afogou. Daniel, como outros meninos que usam o pier para se banhar, não sabia nadar, e poderia ter sobrevivido se ali junto ao T tivesse uma pessoa treinada em salvamento na água.

O evento alterou momentaneamente o equilibrio das coisas. Ferrugem me liga e fala "Eu não sei o que vai ser desse Parque não". A despeito da tragédia (anunciada), a vida seguiu no Parque. 


\section{Conclusão}

\section{"Se eu tivesse que morar aqui eu moraria"}

A frase proferida por Vera, vivenciadora da Prainha do Riacho Grande, que escolheu passar o seu aniversário de 58 anos na beira da Billings no dia 02 de novembro de 2018 é retomada aqui por re- presentar a ideia de que a Billings está em seu imaginário e cotidiano como o lugar da segurança, da memória e do afeto. É a afirmação da represa como um lugar familiar, sugere que aquela Paisagem poderia fazer parte de seu dia a dia. Melhorar clareza da frase

Essa afirmação representa também um processo interno enquanto pesquisadora. Durante a pesquisa me aproximei da represa, passei sábados e domingos com minha família na beira da Prainha, procurei uma chácara para ir com os amigos de final de semana na represa, fiz algumas pontes profissionais e amigos no Cantinho do Céu. Escutar os vivenciadores e decifrar suas práticas fez com que a frase de Vera saisse do lugar da alteridade, $\mathrm{e}$ encontrasse ressonância em mim mesma. Ao fim da pesquisa, passei em algumas ocasiōes meu tempo livre na represa.

Os princípios da Antropologia urbana adotados aqui permitiram abrir uma porta para a escuta e interesse sobre o outro, e minha conclusão ao fim dessa dissertação é que configuram um material fundamental para um arquiteto pensar e projetar espaços públicos de lazer.

As contradiçōes encontradas no caminho quando reinterpretadas pela ótica do lazer abriram um horizonte mais amplo. Se pensarmos o Cantinho do Céu e a Prainha como experiências singulares, caberia um estudo que incorporasse também outros parques, outras "quebradas", outras praias na represa. Nessa ótica, os casos aqui estudados poderiam fazer parte de um sistema de espaços de lazer na represa.

No cantinho do céu, onde o mercado imobiliário formal não esteve presente, a paisagem da represa foi franqueada para todos. Há questionamentos do processo de produção daquele espaço sob várias óticas (investimentos, prioridades, truculência nas remoçōes durante as obras, etc.) mas a implantação do Parque Linear afirma e valoriza a esfera pública e margens como um espaço público livre com alto 


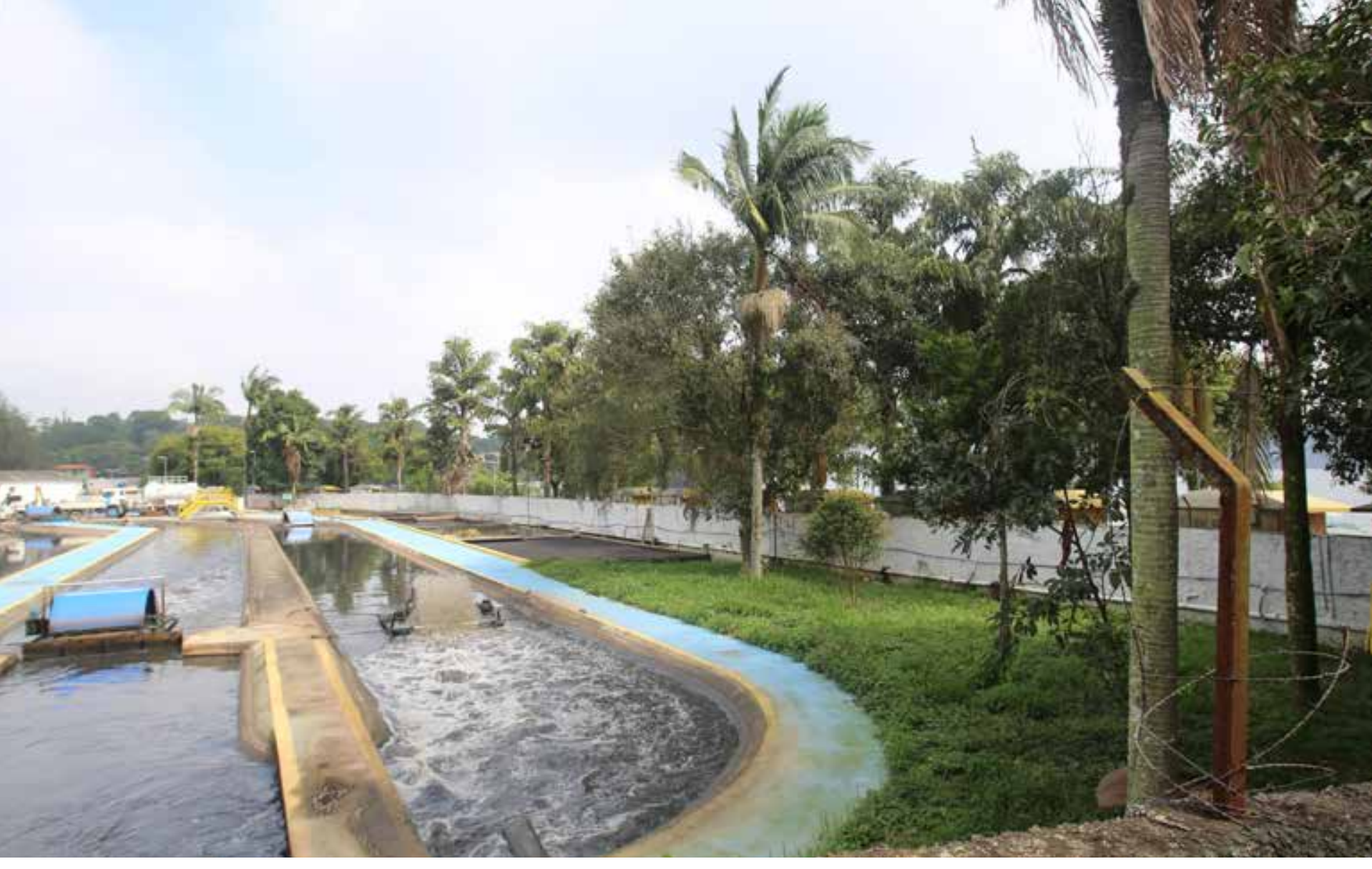

[83] Estação de tratamento de

esgotos ETE Riacho Grande

Foto da autora

27 de Março de 2019, dia do

aniversário da represa 
potencial de usufruto social além de plurifuncional. Embora sem a participação popular direta, houve diálogo com lideranças políticas locais, que trouxeram suas demandas aos projetistas. Coube aos arquitetos interpretá-las em projeto dando espaço para que aquelas demandas fossem atendidas, com abertura suficiente para que outras, não colocadas no momento do projeto, também fossem acolhidas em espaço multifuncional e diverso.

A despeito dos equívocos de projeto na revitalização da Prainha, que propôs o apartamento das pessoas em relação à orla e fracassou nessa proposta, além de dos agentes envolvidos terem dialogado de forma ambígua com usuários ou comerciantes, o espaço segue sendo palco (literalmente) de inúmeras apropriaçōes e usos, revelando uma potência que ultrapassa os equívocos de projeto e processo.

É muito difícil transcender o problema da balneabilidade da represa, em ambos os estudos de caso não tive desejo algum de mergulhar na água por essa hipótese se mostrar arriscada demais. Urge uma abordagem que em curto ou médio prazo dê conta da melhoria significativa da qualidade da água e açōes que revertam a negligência do Estado com os acidentes fatais de meninos na periferia da metrópole. Não se tem enfrentado com consistência os desafios e impasses na gestão das águas do maior reservatório urbano do Brasil e pouco tem se avançado na coordenação de ações de uso e ocupação do solo no manancial. No entanto, alheios a tais condiçōes, moradores Região Metropolitana de São Paulo de todas as classes sociais, continuam indo à represa para se divertir, se confessar, se batizar, namorar ou passear. Esta é a principal questão colocada aqui: se a represa é objeto de interesse de tantas pessoas, cabe um olhar mais generoso para essa Paisagem. 


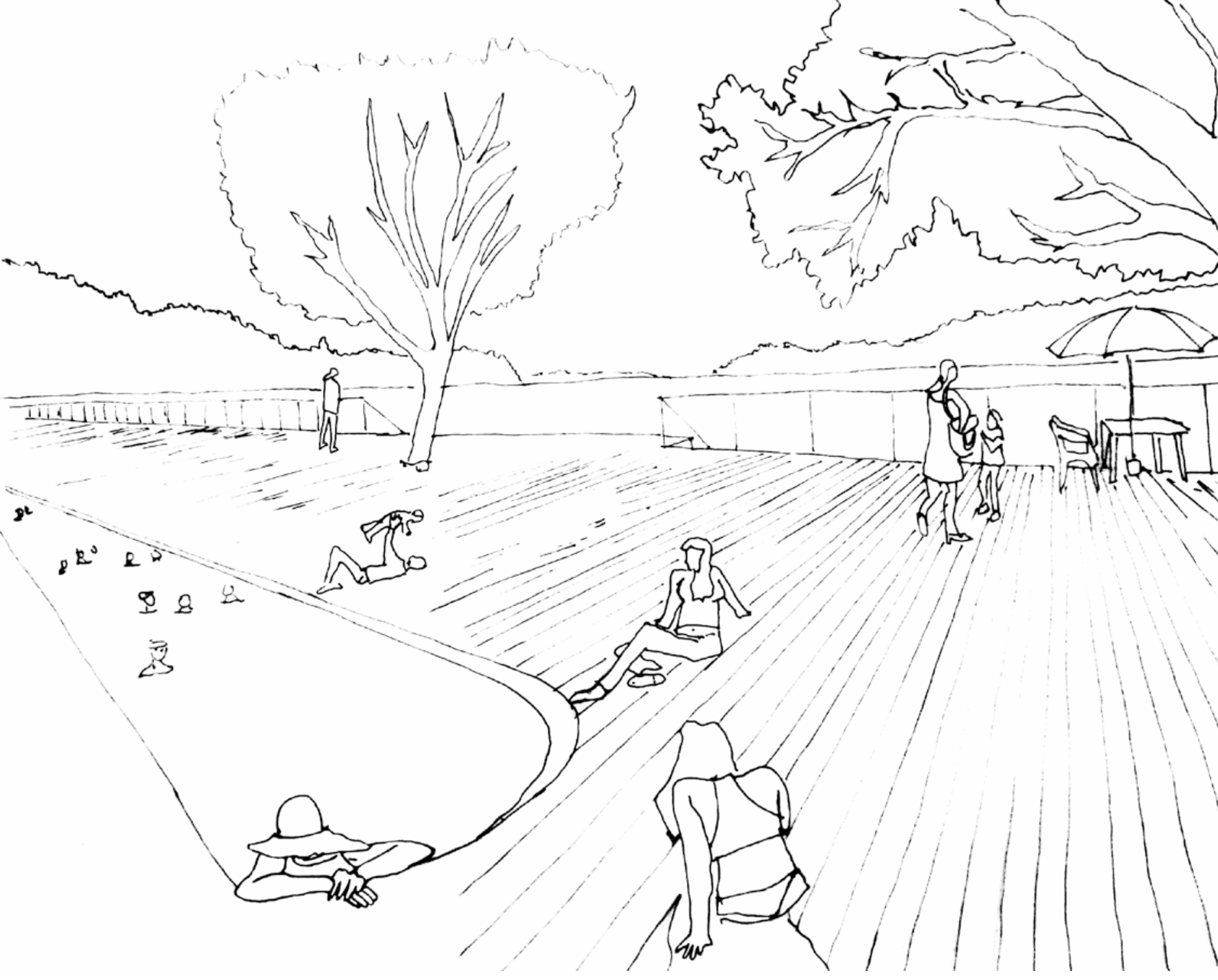




\section{Bibliografia}

AB'SABER, Aziz Nacib. São Paulo: ensaios entreveros. São Paulo: EDUSP/Imprensa Oficial, 2004.

ACKERMAN, Adolph J. Billings and water power in Brazil: a short biography of Asa White Kenney Billings. Madison/ New York: The author/ American Society of Civil Engineers, 1953.

ALEX, Sun. Água e paisagem: questões de paisagismo em torno de um reservatorio de abastecimento na grande São Paulo. São Paulo: FAU-USP, 1985. (Dissertação de mestrado).

ALMEIDA, Vinicius de Souza. Infraestrutura verde urbana na subprefeitura de Capela do Socorro: rede de espaços conservados em áreas de mananciais para sustentação da paisagem, da biodiversidade e suas funções socioambientais. São Paulo: Instituto de Energia e Meio Ambiente - USP, 2015. (Dissertação de mestrado.).

ALVIM, Angélica Tanus Benatti. "A contribuição do Comitê do Alto Tietê à gestão da bacia metropolitana entre 1994 e 2002". Pós / Revista do Programa de pós-graduação em Arquitetura e Urbanismo da FAUUSP. São Paulo: FAU-USP, 2006, n.19, pp.26-44. ALVIM, A. T. B.; KATO, V. R. C.; ROSIN, J. R. G. "A urgência das águas: intervenções urbanas em áreas de mananciais". Cadernos Metrópole, v.17, n.33. São Paulo: PUC-SP, 2015.

ANCONA, Ana Lúcia. Direito ambiental, direito de quem? Políticas públicas do meio ambiente na metrópole paulista. São Paulo: FAU-USP, 2002. (Tese de doutorado).

BACELLI, Ronei. Presença da companhia city em são Paulo e a implantação do primeiro bairro jardim, 1915-1940. São Paulo: FFLCH-USP, 1982. (Dissertação de mestrado).

BERARDI, Maria Helena Petrillo. Santo Amaro: história dos bairros de São Paulo. São Paulo: Secretaria da Educação e Cultura, 1969.

BONZI, Ramón Stock. Andar sobre Água Preta: a aplicação da Infraestrutura Verde em áreas densamente ubanizadas. São Paulo: FAU-USP, 2015. (Dissertação de mestrado.)

BRANDIMILLER, Tatiana Urbanovik. Programa de regularização fundiária sustentável de assentamentos irregulares de São Bernardo do Campo: avanços e desafios ao processo de regularização fundiária no âmbito da política habitacional municipal. São Paulo: FAU-USP, 2017. (Dissertação de mestrado.). BUENO, Laura Machado de Mello. O saneamento 
na urbanização de São Paulo. São Paulo: FAU-USP, 1994. (dissertação de mestrado.).

Cadernos de Educação Ambiental - Edição especial mananciais / Billings. São Paulo: SMA / CEA, 2010. CAPOBIANCO, João Paulo Ribeiro. Billings 2000: ameaças e perspectivas para o maior reservatório de água da região metropolitana de São Paulo. São Paulo: Instituto Sócio ambiental, 2002.

CARMO, Milena Mateuzi. Margem adentro: políticas sociais, sujeito e resistências na zona sul de São Paulo. São Paulo: FFLCH-USP, 2017. (dissertação de mestrado.).

CASTILHO, José Contreras. História do reservatório Billings e as bacias hidrográficas do ABC. s.l., s.n., 1997.

CHADAD, Luiz Alberto Gestas. Da mão à máquina: as fábricas de móveis de São Bernardo do Campo. São Paulo: FFLCH-USP, 2003. (Trabalho de graduação). COMITÊ DA BACIA HIDROGRÁFICA DO ALTO TIETÉ. Plano da Bacia Hidrográfica do Alto Tietê. São Paulo: FUSP/ FEHIDRO, 2002.

- Revisão Plano da Bacia Hidrográfica do Alto Tietê. São Paulo: FUSP/ FEHIDRO, 2009

CORMIER, Nathaniel S.; PELLEGRINO, Paulo R. mesquita. "Infra-estrutura verde: uma estratégia paisagística para a água urbana". Paisagem e ambiente: ensaios. São Paulo: FAU-USP, 2008, pp.125-142.

Diagnóstico da Violência e Criminalidade em São Bernardo do Campo. Prefeitura Municipal de São Bernardo do Campo e Instituto Sou da Paz. São Bernardo do Campo: PMSBC, 2006

DELIJAICOV, Alexandre. Os rios e o desenho da cidade: proposta de projeto para a orla fluvial da Grande São Paulo. São Paulo: FAU-USP, 1998. (Dissertação de mestrado).

São Paulo, metrópole fluvial. São Paulo: FAU-USP, 2005. (Tese de doutorado).
ELETROPAULO. A Cidade da Light - 1899-1930: edição bilingue português-inglês comemorativa dos 5.000.000 de ligações / The City of the Light Company - 1899-1930: bilingual edition portuguese-english 5.000.000 consumers commemorative. São Paulo: Eletropaulo, 1990.

ESCAMES, Edson Fernando. Prospecção da viabilização do uso múltiplo da água no reservatório Billings - São Paulo. Santo André; UFABC, 2018. (Tese de doutorado.).

FAVRET-SAADA, Jeanne. "Ser afetado". Cadernos de campo, n.13. São Paulo: Departamento de Antropologia / FFCHL-USP, 2005, pp.155-161.

FERRARA, Luciana Nicolau. Urbanização da natureza: da autoprovisão de infraestruturas aos projetos de recuperação ambiental nos mananciais do sul da metrópole paulista. São Paulo: FAU-USP, 2013. (Tese de doutorado.).

"Urbanização de assentamentos precários em área de mananciais: um balanço da atuação do poder público e os desafios que permanecem na região metropolitana de São Paulo." Oculum Ensaios, v.15, n.3, 2018. Campinas: PUCCAMP, 2018, pp. 413-435.

FILARDO JUNIOR, Angelo Salvador. Territórios da eletricidade : a Light em São Paulo e o projeto da Serra de Cubatão - 1925-1950. São Paulo: FAU-USP, 1998. (Dissertação de mestrado).

Externalidade

e gestão dos valores do ambiente: considerações teóricas e uma aplicação ao caso do Programa Guarapiranga, 1991-2000. São Paulo: FAU-USP, 2005. (Tese de doutorado).

FRACALANZA, Ana Paula. "Reservatório Billings: apropriação da água, conflitos e gestão". Anais do I Encontro da Associação Nacional de Pós-Graduação e Pesquisa em Ambiente e Sociedade. Indaiatuba, 2002, pp. 1-24. 
FRACALANZA, A. P.; CAMPOS, V. N. O.; "Governança das águas no Brasil: conflitos pela apropriação da água e a busca da integração como consenso." Ambiente e Sociedade, v.13. Campinas, 2010, pp.365-382.

FRANÇA, Elisabete (coord.). Guarapiranga: recuperação urbana e ambiental no município de São Paulo. São Paulo: Marcos Carrilho Arquitetos, 2000. Favelas em São Paulo (1980-2008): das propostas de desfavelamento aos projetos de urbanização, a experiência do programa Guarapiranga. São Paulo: FAU-UPM, 2009.

FRANÇA, Elisabete; BARDA, Marisa (orgs.). Entre o céu e a água: o cantinho do céu. São Paulo: Prefeitura de São Paulo, 2012.

IDOETA, Irineu. São Paulo vista do alto: 75 anos de aerofotogrametria. São Paulo: Érica, 2004.

LANGENBUCH, Juergen Richard. A estruturação da Grande São Paulo. Rio de Janeiro: Instituto Brasileiro de Geografia/ Departamento de Documentação e Divulgação Geográfica e Cartográfica, 1971.

Lei $n^{\circ}$ 13.579, de 13 de julho de 2009 - Assembleia Legislativa do Estado de São Paulo.

LEITE, M. A. F. P.; FERRARA, L. D.; GHOUBAR, K.; MAUTNER, Y.; OSEKI, J. H.; PELLEGRINO, P. R. M. "As margens do rio". Anais do Seminário Metrópoles Latino-americanas II. São Paulo: FAU USP, 1992, v. 3, pp. 127-135.

MACHADO, Giancarlo M. Carraro. De "carrinho" pela cidade: a prática do street skate em São Paulo. São Paulo: FFLCH-USP, 2011. (Dissertação de mestrado). "Natureza e parti-

cipação social, uma nova estética para o desenho urbano", Pós / Revista do Programa de pós-graduação em Arquitetura e Urbanismo da FAUUSP. São Paulo: FAU-USP, 1993, n.3, pp.19-26.

MAGNANI, José Guilherme Cantor. Festa no pedaço: o circo-teatro e outras formas de lazer e cultura popular. São Paulo: FFLCH-USP, 1982. (Tese de doutorado.).

Da periferia ao centro: trajetórias de pesquisa em antropologia urbana. São Paulo: Editora Terceiro Nome, 2012.

"De perto e de

dentro: notas para uma etnografia urbana". Revista brasileira de Ciências sociais, v.17, n.49. São Paulo: ANPOCS, 2002, pp.11-29.

"A antropologia

urbana e os desafios da metrópole". Tempo social: revista de sociologia da USP, n.15. São Paulo: Departamento de sociologia / FFLCH-USP, 2003, pp.81-95. MARENGO, J. A.; NOBRE, C. A.; SELUCHI, M. E.; CUARTAS, A.; ALVES, L. M.; MEDIONDO, E. M.; OBREGÓN, G.; SAPAIO, G. "A seca e a crise hídrica de 2014-2015 em São Paulo". Revista USP, n.106. São Paulo: USP, 2015, pp. 31-44.

MARICATO, Ermínia. Metrópole na periferia do capitalismo. São Paulo: Hucitec, 1996.

MATSUNAGA, Melissa Kikumi. Cantinhos do céu. São Paulo: FAU-USP, 2015. (Dissertação de mestrado.).

Monolito - Arq. Futuro: a cidade e a água. São Paulo: Editora Monolito, 2013.

MORAES, Paulo Roberto. Península do Riacho Grande: Uma abordagem geográfica na análise ambiental. São Paulo: FFLCH-USP, 1994. (Dissertação de mestrado.).

MOREIRA, Renata M. Pinto. Distribuição de águana região metropolitana de São Paulo: tecnologias de universalização e produção do espaço. São Paulo: FAU-USP, 2008. (Dissertação de mestrado.).

MOURA, Rafael Moraes e RODRIGUES, Eduardo. "Interligação de Billings com Alto Tietê deve ser entregue em maio, diz Alckmin". O Estado de $S$. Paulo. 30 de janeiro de 2015.

Observatório de remoções - Laboratório de Habi- 
tação e Assentamentos Humanos e Laboratório do Espaço Público e Direito à Cidade da Faculdade de Arquitetura e Urbanismo da USP. Por um observatório das remoções no município de São Paulo. São Paulo: FAU-USP, s.d.

OSEKI, Jorge Hajime. "A fluvialidade em rios paulistas". In: COSTA, Lúcia Maria Sá Antunes (org.), Rios e paisagens urbanas em cidades brasileiras. Rio de Janeiro: Viana \& Mosley/ PROURB, 2006, pp. 77-95. PASCHKES, Maria Luisa N. de A. "Bondes, terrenos e especulação". História e energia. São Paulo: Eletropaulo / Departamento de Patrimônio Histórico da Eletropaulo, 1986.

PENTEADO, C. L. C.; ALMEIDA, D. L.; BENASSI, R. F. "Conflitos hídicos na gestão dos reservatórios Billings e Barra Bonita". Revista de Estudos Avançados, n.31. São Paulo: IEA-USP, 2017, pp. 299-322. PEREIRA, Raul Isidoro. O sentido da paisagem e a paisagem consentida: projetos participativos na produção do espaço livre público. São Paulo: FAUUSP, 2006. (Tese de doutorado.).

Plano Diretor de Aproveitamento de recursos Hídricos para a Macrometrópole Paulista no Estado de São Paulo, Relatório final - volume I. São Paulo: CEBRAPE, 2013

Plano estadual de recursos hídricos 2004-2007 relatório síntese do plano. São Paulo: SSRH / DAEE, 2005.

Planos regionais estratégicos - PRE: município de São Paulo / Subprefeitura Capela do Socorro. São Paulo: PMSP/SEMPLA, 2004.

POLLI, Simone Aparecida. Moradia e meio ambiente: os conflitos pela apropriação do território nas áreas de mananciais em São Paulo. Rio de Janeiro: IPPUR-UFRJ, 2010. (Tese de doutorado.).

QUEIROGA, Eugenio Fernandes. A produção da paisagem habitacional metropolitana: Três estudos de caso no Município de Osasco. São Paulo, FAU-
USP, 1994.

Relatório técnico do Plano Diretor SANEGRAN Resumo. Revista DAE, edição 110, n.380, 1977. SANTORO, P. F.; FERRARA, L.N.; Whately, M. (orgs.). Mananciais: diagnóstico e políticas habitacionais. São Paulo: Instituto Socioambiental, 2009.

SANTORO, Paula. Leitura urbanística de duas ocupações em São Paulo: Cantinho do Céu, no Grajaú, e Heliópolis, em Sacomã. São Paulo,UNICEF/ Instituto Pólis, 2008

DOS SANTOS, Wanderley. Antecedentes Históricos do ABC Paulista: 1550-1892. São Bernardo do Campo: Prefeitura do Município de São Bernardo do Campo, 1992

SEABRA, Odette. Os meandros dos rios nos meandros do poder. São Paulo: FFLCH-USP, 1987. (Tese de doutorado).

Secretaria do Meio Ambiente. A água no olhar da História. Governo do Estado de São Paulo, 2000.

SILVA, R. T.; PORTO, M. F. do Amaral. Gestão Urbana e gestão das águas: caminhos da integração. Revista de Estudos Avançados, v.17, n.47. São Paulo: IEA-USP, 2003, pp.129-146.

SPINELLI, J.J.; TRIMANO, C.; LAZZARO, C.S; LOPES, V.V. Transformações: arte urbana e cidadania. São Paulo: Via das Artes / Zupi, 2015.

WERTHMANN, Christian. Operações táticas na cidade informal. São Paulo: SEHAB, 2009.

\section{Notícias de jornal/ publicações periódicas online}

"Billings é grande caixa d'água de São Paulo, diz Alckmin". Diário do Grande ABC. 30 de janeiro de 2015. Disponivel em <https://noticias.r7.com/sao- paulo/billings-e-a-grande-caixa-dagua-da-cidade-de-sao-paulo-diz-alckmin-30012015> Acesso em 29 Mar.2018

"É tanto esgoto que a cor da água da Bil- 
lings sofre os efeitos". Diário do Grande ABC. 18 de janeiro de 2017.Disponível em https://www.dgabc.com.br/Noticia/2773963/ e-tanto-esgoto-que-ate-a-cor-da-agua-da-billingssofre-os-efeitos Acesso em 20 Mar.2018

"Maioria dos homicídios acontece longe da região central no $A B C$ ". Metro $A B C$. 28 de fevereiro de 2019. Disponível em <https://www.metrojornal.com.br/foco/2019/02/ 28/maioria-homicidios-longe-centro-abc.html>, Acesso 01.Mar.2019

"Piratas atacam turistas na represa Billings" Folha de São Paulo. 16 de Dezembro de 2001. Disponível em : <https://www1.folha.uol.com.br/ fsp/cotidian/ff1612200134.htm> Acesso em 18 Set 2018

"Represa Billings não está para peixe" Diário do Grande ABC. 10 de agosto de 2004. Caderno Setecidades, p.2

"Vídeo registra morte de piloto em acidente com moto aquática no ABC". Portal G1. 27 de agosto de 2014. Disponível em: < http://g1.globo.com/sao-paulo/noticia/2014/08/video-registra-morte-de-piloto-em-acidente-com-moto-aquatica-no-abc. html> Acesso em 13.Abr.2018

FERRAZ, Yara. "Billings é caixa-d'água de São Paulo, afirma presidente da Sabesp - Diário do Grande ABC. 15 de janeiro de 2015. Disponível em: < https://www. dgabc.com.br/Noticia/1117028/billings-e-caixa-d-agua-de-sao-paulo-afirma-presidente-da-sabesp?referencia=buscas-lista> Acesso em 29 Mar.2018 HISAYASU, Alexandre, RIBEIRO, Bruno e TOLEDO, Luiz Fernando. "Em menos de um ano surgem 32 invasões as margens da represa". O Estado de $S$. Paulo. 22 de setembro de 2016. Disponível em:< https://sao-paulo.estadao.com.br/noticias/geral,em-menos-de-1-ano-surgem-32-invasoes-as-margens- -de-guarapiranga-e-billings,10000078072> Acesso em 25.Abr.2018

MARTÍN. María. "Sob pressão, Alckmin admite racionamento pela primeira vez". El País Brasil. 14 de janeiro de 2015. Disponivel em:< https://brasil.elpais.com/ brasil/2015/01/14/politica/1421252195_864485. html> Acesso em 29 Mar.2018

MEDICl, Ademir. "Batelões de lenha e fé". Diário do Grande ABC. 26 de agosto de 2018. Caderno Setecidades/História, p.2

"Dutos, lama, sacaria na Billings de 1963". Diário do Grande ABC. 11 de fevereiro de 2014. Caderno Setecidades/História, p.2

MUNHOZ, Fábio. "Pilotos de jet skis colocam em risco banhistas na Prainha da Represa Billings" Diário do Grande ABC. 16 de novembro de 2010. Disponível em: https://www.dgabc.com.br/Noticia/224566/pilotos-de-jet-skis-colocam-em-risco-banhistas-na-prainha-da-represa-billings. Acesso em 15.Maio.2018 PACHECO, Patrícia. "Há solução para a crise da água em São Paulo". Motherboard. 12 de novembro de 2015. Disponível em: < https://motherboard.vice. com/pt_br/article/9aqeqv/a-crise-hldrica-persiste-em-sao-paulo>. Acesso em 17.Set.2018 RIBEIRO, Bruno. "Sem-teto invadem e desmatam área de $38 \mathrm{mil} \mathrm{m}^{2}$ à beira da Billings em SP". O Estado de S. Paulo. 28 de julho de 2016. Disponível em: < https://sao-paulo.estadao.com.br/noticias/geral,sem-teto-invadem-e-desmatam-area-de-38-mil-m2-a-beira-da-billings-em-sp,10000065392>. Acesso 12.Dez.2018

SANTOS, Leonardo. "Prainha está imprópria para banho ". Diário do Grande ABC. 12 de novembro de 2016 Caderno Setecidades, p.4

SELICANI, Vanessa. "Billings tem melhora na água, mas sofre com assoreamento". Metro Jornal ABC. 22 de junho de 2017. Disponível em:< https://www. metrojornal.com.br/foco/2017/06/22/billings-tem- 
-melhora-na-agua-mas-sofre-com-assoreamento. html $>$, Acesso 03.Mar.2019

"Morador do Riacho Grande

tem 55\% mais doenças ligadas a água". Metro Jornal ABC. 1区 de dezembro de 2017

SIQUEIRA, Felipe. "Estudo deve rever Lei da Billings pela Assembleia . Diário do Grande ABC. 25 de abril de 2017.

SIVIERO, Samir e RESK, Sucena Shkrada. "Estação de Riacho Grande vai tratar esgoto. Diário do Grande ABC. 27 de abril de 2003.

SANT'ANNA, Emílio. "Esperança contra crise da água em SP, Billings é caixa-preta de poluição". Folha de São Paulo. 1囚 de fevereiro de 2015.

VASCONCELOS, Mônica. "São Paulo está preparada para enfrentar a estiagem". BBC Brasil. 5 de maio de 2015. 
Anexo 


\section{emae}

\section{SÃO}

RELATÓRIO

\section{ATENDIMENTO À PESQUISA ACADÊMICA}

\section{Mestranda Ana Carolina Ayres Gimenez}

\section{Orientador Prof. Dr. Eugenio Fernandes Queiroga}

\section{Março/2019}

EMAE - Empresa Metropolitana de Águas e Energia S.A. Av. Nossa Senhora do Sabará, 5312 | CEP 04447-902 | São Paulo - SP Fone: (11) 5613-2100 | www.emae.com.br 


\section{ang}

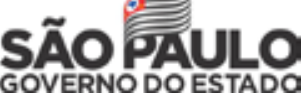

\section{Prainha Riacho Grande}

Trata-se de área integrante do Reservatório Billings (cota de inundação $747 \mathrm{~m}$ RN EPUSP).

Essa área está situada no distrito de Riacho Grande, no município de São Bernardo do Campo, próximo à rua Amazonas.

Em 22/01/1974 a então Light - Serviços de Eletricidade S.A (antecessora da EMAE) firmou com a Prefeitura Municipal de São Bernardo do Campo um contrato de comodato, tendo por objeto uma faixa de terras situada na margem do Reservatório Billings, distrito de riacho Grande, município de São Bernardo do Campo, com aproximadamente 780 metros de extensão. O terreno deveria ser usado exclusivamente para acesso às águas, podendo, todavia, ser aproveitado para plantação de gramados, hortaliças ou outras espécies vegetais rasteiras de ciclo rápido.

No decorrer do tempo, com concordância da EMAE, a área foi utilizada para outros fins, como $1^{\text {a }}$ Festa da Primavera (02 de outubro e 20 de novembro de 2005), $1^{\circ}$ Mega Encontro Moto ciclístico Beneficente $(29,30$ e 31 de maio de 2009) e festejos de 61 anos de criação do Distrito de Riacho Grande (12 e 13 de dezembro de 2009).

Concomitantemente o local foi sendo ocupado por trailers e barracas para comércio e estacionamento irregular, inicialmente apenas nos finais de semana, passando a se instalarem permanentemente, não obstante às solicitações verbais e formais promovidas pela EMAE.

Permanecendo as irregularidades a EMAE, em 2009, ajuizou ação de reintegração de posse.

Em março de 2010 a Prefeitura do Município de São Bernardo do Campo apresenta projeto de Revitalização e Requalificação da Prainha de Riacho Grande, o qual foi analisado pelas áreas técnicas e patrimonial da EMAE, obtendo a formalização da anuência, condicionada à retirada das ocupações irregulares e à obtenção de licenciamento junto aos órgãos ambientais competentes.

Em dezembro/2010 aquela municipalidade solicita alterações no documento de anuência, obtendo a concordância da EMAE.

Em junho/2011 é apresentado o licenciamento emitido pela CETESB.

Em dezembro/2011 a Prefeitura de São Bernardo apresenta projeto executivo de Requalificação da Prainha do Riacho Grande, contendo urbanismo, paisagismo, arquitetura, instalações, geometria, drenagem, estrutura, iluminação, implantação, perspectiva e memorial descritivo.

EMAE - Empresa Metropolitana de Águas e Energia S.A. Av. Nossa Senhora do Sabará, 5312 | CEP 04447-902 | São Paulo - SP Fone: (11) 5613-2100 | www.emae.com.br 


\section{onve \\ SÃO}

Em abril/2012, a pedido da EMAE, a prefeitura encaminha revalidação da autorização ambiental emitida pela CETESB e revisão do projeto executivo.

Em junho/2012 a EMAE responde à prefeitura informando que não está autorizada qualquer intervenção abaixo da cota de nível d'água do Reservatório Billings (747m RN EPUSP), excetuando-se a construção de rampa de acesso a embarcações, acrescentado que os decks deverão ser suspensos de forma a não comprometer a capacidade de armazenamento e a operação do referido reservatório.

Em novembro/2012 a EMAE solicita brevidade no envio do projeto executivo com as adequações solicitadas em junho/2012, sendo atendida pela prefeitura em dezembro/2012.

Em dezembro/2012 a EMAE expede ofício autorizando a utilização da área para implantação de rampa de acessibilidade que faz parte do projeto de Requalificação da Prainha do Riacho Grande. Devolvido em novembro/2013 com o "De acordo" da Prefeitura.

Em novembro/2013 houve audiência de conciliação entre as partes tendo o juiz determinado que a prefeitura fosse convocada para prestar esclarecimentos sobre a mudança dos trailers e solicitou á EMAE que providenciasse relatório do local identificando sua propriedade e as ocupações existentes, o que foi providenciado.

Em maio/2016 a ação de reintegração de posse foi julgada parcialmente procedente, devendo a área ocupada pelos comerciantes (trailers, barracas e estacionamento) ser desocupada, permanecendo, no entanto, as intervenções realizadas pelo município.

Assim, a área permanece cedida à Prefeitura de São Bernardo do Campo, por meio do contrato de comodato firmado em 22/01/1974.

Em fevereiro de 2017, 2018 e 2019 foram realizados no local eventos denominados "Verão Riacho Grande". 


\section{ang}

\section{SOÃOFAULOLO}

\section{Parque Linear Cantinho do Céu}

Trata-se de área integrante do Reservatório Billings (cota de inundação $747 \mathrm{~m}$ RN EPUSP).

O local está situado na zona sul da cidade de São Paulo, com forte adensamento urbano, composto basicamente por moradias de baixa renda.

Em setembro/2008 a Secretaria Municipal de Habitação, da Prefeitura de São Paulo, encaminhou projetos do Programa Mananciais que atingiam várias áreas sob responsabilidade da EMAE, integrantes dos Reservatórios Billings e Guarapiranga, inclusive aquelas situadas no bairro Cantinho do Céu.

Em dezembro/2008 a EMAE emitiu ofício anuindo ao pleito, em caráter precário e com o objetivo exclusivo de obtenção de concessão de outorga junto aos órgãos ambientais competentes.

Em dezembro/2012 a SEHAB/PMSP encaminha relatório com informações da fase 3 do Programa Mananciais, com interferências em áreas integrantes dos Reservatórios Billings e Guarapiranga, inclusive no bairro Cantinho do Céu.

Em abril/2013, a EMAE emite ofício anuindo ao pleito, em caráter precário e com o objetivo exclusivo de obtenção de concessão de outorga junto aos órgãos ambientais competentes. Não houve resposta da SEHAB concordando com as condições.

Em julho/2014 a EMAE encaminha ofício à SEHAB informando sobre aumento considerável das ocupações na área denominada Cantinho do Céu e arredores, propondo união de esforços para conter essa atividade.

Em agosto/2014 a SEHAB encaminha estudo de concepção para implantação do Parque Fase 2 - Complexo Cantinho do Céu - Programa Mananciais - Fase III, solicitando indicação das divisas das propriedades da EMAE e informações sobre batimetria existente do reservatório Billings, assim como documentação do histórico referente ao regime das águas, para auxiliar o desenvolvimento do projeto executivo.

Em agosto/2014 a SEHAB se compromete a encaminhar os levantamentos topográficos da região para subsidiar estudos da EMAE.

Em outubro/2014 a EMAE encaminha informações sobre série histórica de níveis d'água e batimetria.

Em outubro e novembro/2014 a EMAE informa à SEHAB sobre aumento das ocupações irregulares.

EMAE - Empresa Metropolitana de Águas e Energia S.A. Av. Nossa Senhora do Sabará, 5312 | CEP 04447-902 | São Paulo - SP Fone: (11) 5613-2100 | www.emae.com.br 


\section{emae}

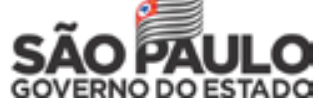

Em janeiro/2016 a EMAE informa à SEHAB sobre constatação de reocupações em locais onde já havia tido atuação do Programa Mananciais, principalmente na área do Complexo Cantinho do Céu, indagando sobre a continuidade do Programa Mananciais.

Em outubro/2018 a SEHAB solicita à EMAE autorização para implantação de um trecho do Parque Linear Cantinho do Céu, denominado Frente 1, da Etapa 5, encaminhando licença de instalação da CETESB. Esse trecho situa-se próximo da Avenida São Paulo e Rua 9 de Setembro e ocupará $939,19 \mathrm{~m}^{2}$ de área pertence à EMAE. Não vendo óbices de ordem técnica, patrimonial ou jurídica, o respectivo instrumento formalizador da cessão gratuita está sendo providenciado pela EMAE.

Em fevereiro/2019 a SEHAB solicita à EMAE autorização para implantação parcial do Parque Linear Cantinho do Céu, na região denominada Etapa 2, Trechos 1 e 2, Fase 3 do Programa Mananciais, encaminhando a respectiva licença emitida pela CETESB. Essa cessão ocupará duas áreas, sendo uma com $133,46 \mathrm{~m}^{2} \mathrm{e}$ outra com $6.454,79 \mathrm{~m}^{2}$. O projeto apresentado está sendo analisado pelas áreas técnicas da EMAE.

EMAE - Empresa Metropolitana de Águas e Energia S.A. 


\section{Apêndice}

Neste apêndice são apresentadas as entrevistas que foram gravadas e posteriormente transcritas para utilização de alguns trechos no corpo do texto. Foram realizadas entre Outubro de 2018 e fevereiro de 2019. Os entrevistados, conforme enunciado na introdução do trabalho, foram separados em duas categorias: vivenciadores e técnicos, os primeiros aqueles que experienciam os espaços estudados e os técnicos aqueles que agem no espaço através de instituições.

Além das entrevistas transcritas, foi mantido um caderno de campo com endereços, telefones úteis, anotações, croquis e transcrições de conversas que não foram gravadas, mas que foram incorporadas na dissertação. (inserir foto do caderno). Todos os deslocamentos até o Cantinho do Céu e Prainha do Riacho foram feitos de carro, num total de quase $1500 \mathrm{~km}$ percorridos. O percurso de carro possibilitou uma certa agilidade na realização das visitas ${ }^{1}$ nos 5 meses de estudo de

1. Ao todo para a pesquisa foram feitas em torno de 20 visitas distribuidas igualmente entre o Parque Linear e a Prainha. O número exato pode extrapolar se considerar as idas que fiz antes do período em que eu estava fazendo o campo, antes da qualificação, entre janeiro e março de 2018. campo. Mesmo assim, após a primeira visita ao Cantinho do Céu, no dia 17 de Outubro de 2018, uma forte chuva trazida pelos ventos do litoral caiu na zona sul e alagou a marginal Pinheiros na altura da ponte do Socorro, me mantendo apreensiva e parada por 2,5 horas até que cessassem os pontos de alagamento. Nesse dia, tive uma breve experiência das dificuldades enfrentadas pelos moradores do Grajaú no deslocamento até áreas centrais, que de transporte público, descontando os dias em que ocorrem acidentes na Belmira Marin, pode demorar entre 2 e 3 horas todos os dias.

No cantinho do céu as entrevistas foram realizadas no próprio Parque Linear, com exceção da entrevista com Enivo. O artista foi entrevistado em sua casa/atelier no bairro da aclimação em fevereiro de 2019 na semana que sucedeu a morte por afogamento de um ex-aluno do Ferruge (01.02.2019). A entrevista com Tim foi feita em frente à mesa de pinque-pongue na segunda quinzena de janeiro de 2019. Infelizmente perdi o áudio por conta de um problema técnico, mas resgatei de memória a entrevista e as conversas 
que tivemos presenciais e por telefone, sendo a primeira delas na casa ecoativa na ilha do Bororé no dia 17 de novembro de 2018. Ao todo foram 4 encontros, sendo o último deles agendado para um sábado, dia 19 de janeiro de 2019 ocasião em que sentamos num banco e conversamos por 1h30 vendo os meninos brincarem no pier, as vacas pastarem no parque, enquanto meu interlocutor contava a história do Imargem e de todos os outros coletivos dos quais fazia parte, reforçando a fala de Enivo dias depois de que Tim era "o cérebro do Imargem" e atuava em "tudo".

Na reta final de encerramento da pesquisa me dei conta que ao constatar em diversas visitas a presença física em maior quantidade de homens no Parque, eu havia falhado ao não ter incluído também entre meus interlocutores as mulheres que estavam à frente de outros coletivos artísticos com outros homens, como o Abebé, ou mesmo os coletivos só de mulheres como o GrajaMinas e Mulheres na Luta, assim deixei de entender como e esses coletivos se apropriam do Parque. Embora soubesse da importância das lideranças femininas na luta pela implantação de melhorias para o bairro e mesmo a frente de cooperativas atuantes no Grajaú e no Parque, como a Cooperpac2, a pesquisa falha ao não trazer essas vozes para a dissertação. Feita a ressalva, algumas interlocutoras apareceram nas conversas que tive com Ferruge, especialmente no dia da entrevista

2. A cooperpac é uma cooperativa de reciclagem que nasceu em 2010 da iniciativa de mulheres que estavam no mercado informal e atuavam porta a porta na coleta de resíduos recicláveis. Em 2015 estabeleceu um convênio com a prefeitura e passou a receber também lixo coletado por empresas concessionárias. Valquíria uma das principais lideranças da empresa, que continua majoritariamente feminina, palestrou no "anfiteatro" no Parque Linear na feira de encerramento da Unigraja em 2018, ocasião em que eu estava presente na plateia. A Cooperpac, faz parte do grupo de coletivas da Unigraja, que inclui também o Imargem de Tim e o Meninos da Billings de Ferruge. "agendada".

No dia 31 janeiro de 2019 gravei nossa conversa após uma série de 5 encontros em diferentes datas entre Outubro de 2018 e janeiro de 2019. Nesse dia, pude acompanhar sua rotina entre 09h30 da manhã e 16h30.

Cheguei ao Parque às $09 \mathrm{~h} 00$ e vi ele organizando a diária dos funcionários da empresa de manutenção e poda. Entre orientação e outra aos jardineiros, ele parava para conversar com várias pessoas conhecidas que cruzavam nosso caminho, ou mesmo nas portas das casas e ia explicando o porquê da demora na poda, que seguia um calendário da prefeitura que era longe da frequência ideal.

Ferruge me contou que a Dona Vera, que não foi entrevistada nessa pesquisa, havia sido peça fundamental na implantação do Parque e principal interlocutora entre os moradores com a equipe de projeto do escritório de arquitetura, mas que naquela semana em que o entrevistei ela havia feito um abaixo-assinado para destituí-lo do cargo de gestor pois, nas palavras de Ferruge, "ela acha que sou negligente com a manutenção, como se isso dependesse exclusivamente de mim. E olha que eu fico em cima, porque tem um monte de morador que joga lixo de casa nos lixos do Parque, quando não resolvem jogar entulho também", e que por essa razão o clima entre eles não estava bom.

Numa dessas conversas que transcorreram ao longo do dia, parei, junto com Ferruge, na porta de Dona Lurdes, que havia atuado como liderança do bairro junto com Dona Vera. Ficamos ali uns 30 minutos conversando sobre as melhorias que Dona Lurdes acompanhara, seu engajamento e os novos conflitos agora trazidos pela antiga companheira de luta. Segundo Dona Lurdes, Dona 
Vera ainda guardava mágoas por não continuar na gestão do Parque. Dona Lurdes, ao falar, tratava Ferruge como filho e me tratava com afetuosidade semelhante, e pedia calma e paciência a Ferruge. Meu entrevistado por outro lado solicitou a Dona Lurdes que intercedesse por ele e saímos da conversa com um pedido de Ferruge para Dona Lurdes "pede para ela se acalmar lá, estou fazendo meu melhor, mas as pessoas daqui precisam ajudar também, o parque é de todo mundo".

O que percebi é que mesmo dizendo-se não político, Ferruge tinha uma habilidade que consistia em dialogar pacificamente com os mais diversos públicos, desde os mais velhos até os mais jovens. Após gravar a entrevista, na escadaria em frente ao pier, continuamos conversando e almoçamos no bar do Ceará, quando ele me contou as peripécias da sua juventude no bairro e como aprendeu a transitar entre "boys e maloqueiros".

A tarde visitamos a obra de recuperação da ponte de madeira, paramos no bar de um amigo do Ferruge, que me ofereceu um café e uma água e na sequência fui convidada a entrar na casa do William, bem em frente ao arco3. William abriu as portas e me guiou pela casa. Na última laje, ainda sem acabamentos, ele mantinha um viveiro de plantas e uma oficina. Era ali que ele produzia os lixos para o parque, todos feitos com garrafas pet, algumas delas doadas pela Cooperpac. Na saída da casa, Ferruge me confessou que acharia bom se William o sucedesse na gestão do Parque.

No Riacho Grande comecei formalmente as entrevistas com aplicação de questionário no feriado do dia 2 de novembro de 2018. Nesse dia foram entrevistadas pessoas aleatórias que

3 (estrutura projetada para servir de tela de projeção, mas que acabou sendo apropriada como escultura e totem, ganhando status de localidade no Parque a ponto das pessoas falarem: vamos lá no arco?). estavam na Praia disfrutando o dia ensolarado com amigos e familiares.

Além dessas entrevistas, eu havia feito contato com um grupo de salva-vidas em fevereiro de 2018 e com o Marinheiro Cláudio, com quem fiz um passeio de barco e mantive contato mais frequente entre setembro de 2018 e fevereiro de 2019. Cláudio é um personagem singular. Em todas as ocasiões que nos encontramos, ele fazia algum tipo de denúncia ou expressava sua revolta em relação a situação da Prainha. Curiosamente era o mesmo tom que adotava desde meu primeiro contato lá nos idos de 2008 quando conheci a Prainha e ainda estava na graduação. Foi quando fiz meu primeiro passeio de lancha na Billings e fui guiada pelo Marinheiro, como ele gosta de ser chamado. Durante essa pesquisa, as várias tentativas que fiz para agendar uma entrevista gravada falharam, então procurei incorporar suas histórias através das anotações no caderno de campo e memória. Esse formato também foi utilizado para as entrevistas com Lucas Cavinato, Lucia Cavinato e Carlos Vieira, essas três últimas foram conversas entre janeiro de fevereiro de 2019.

Depois das entrevistas com questionário procurei o Ivar, subprefeito do distrito. Ele é um personagem ambíguo, as vezes fala de sua história no Riacho, mas sempre que pode faz política partidária. Ainda assim, na entrevista que fiz no dia 23 de novembro de 2019, apareceram muitas histórias e memórias do Riacho, razão pela qual mantive ele na categoria de vivenciador e não de técnico. Minha relação com Ivar permitiu a aproximação com a família de Quirino Vizentin (Leli), que entrevistei coletivamente em 7 de dezembro de 2018, estando presente os filhos Laércio e Solange, e a sua esposa Terezinha Conrado Vizentin. A "entrevista" de quase 3 horas terminou 


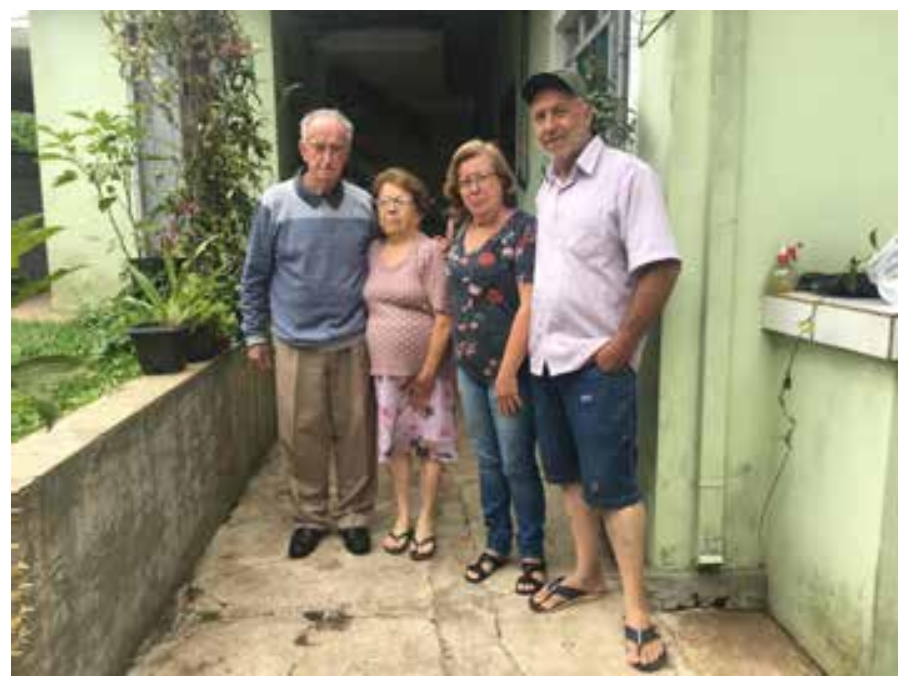

[85] Família Vizentin

Carolina Gimenez, 2018

com Leli me entregando uma muda de flor de cera, um tipo de trepadeira que dá flores em cachos. Permaneci em contato com a família por telefone e encontrei o casal Vizentin outras 2 vezes em eventos relacionados a represa.

Optei também por transcrever as entrevistas dos técnicos cujas falas incorporei em alguns trechos da dissertação. São as 6 últimas entrevistas que encerram o apêndice. 


\section{Vivenciadores}

Ferruge, Adolfo Duarte, 38 anos, administrador do Parque Linear Cantinho do Céu e dono da ONG meninos da Billings, que promove vivências náuticas na represa. Veio com os pais para o Cantinho do Céu com 8 anos e depois construiu sua casa no mesmo bairro

CAROLINA: Eu vou fazer umas perguntas pessoais e depois umas perguntas sobre o parque, mas se entrarem outras histórias no meio não tem problema nenhum. Você é aqui do Grajaú?

FERRUGE: Sou do Grajaú. Na verdade, nasci em Interlagos. Vim pro Grajaú com meus pais na década de 1990.

CAROLINA: Em que ano você nasceu?

FERRUGE: Em 1981. Estou com 37.

CAROLINA: E como é o seu dia a dia?

FERRUGE: Bem corrido, bem movimentado. Levanto às sete da manhã dia de semana; final de semana um pouco mais tarde. Ultimamente, estou procurando andar um pouco, pedalar. Oito horas, estou de volta em casa, vou para o parque, este ou o Prainha; e duas vezes por semana procuro ir lá para o outro parque, no Aeroporto, que é o Parque do Chuvisco.

CAROLINA: Então, você está administrando três parques?

FERRUGE: Três parques.

CAROLINA: É possível fazer isso?
FERRUGE: É possível se você tem uma equipe que colabora. Eu costumo falar que a minha gestão é colaborativa. As pessoas ajudam muito, participam muito, e eu distribuo as vitórias. A responsabilidade é toda minha, mas as coisas vão acontecendo, procuro distribuir bem as responsabilidades, cada um no seu quadrado, claro. Tenho três lideranças boas nos três parques, três equipes boas de segurança; e o pessoal da limpeza é superparceiro, é amigo, a gente conversa bastante. As equipes trabaIham dia sim, dia não, mas são equipes fechadas. A gente conversa bastante, tem grupo no Whatsapp...

CAROLINA: São sempre as mesmas pessoas...

FERRUGE: Já fui chamado para vir de madrugada no parque porque tentaram roubar um barco. Esses caras são bem fechados comigo, por enquanto.

CAROLINA: Legal, tem uma parceria boa.

FERRUGE: Vamos ver até quando.

CAROLINA: Mas por quê?

FERRUGE: Porque muda. Lá no Parque do Chuvisco, por exemplo, o líder era um cara que tinha outro conceito. Ele trabalhou só dois meses. Tive que recolher ele, nunca imaginei que ia ter que pedir para mandar alguém embora um dia. Mas é um cara que veio de outro parque maior, acabou me dando alguns problemas de presença. Eu preciso do cara lá; o segurança patrimonial é meu olho, se eu não estou, ele está olhando: "Olha, quebrou um galho aqui", "Ah, beleza, estou indo aí agora dar uma olhada". 
CAROLINA: E mesmo essa questão de evitar conflitos entre pessoas, imagino...

FERRUGE: Eu costumo falar para os caras que eles são mediadores de conflitos; eles não são seguranças, eles são seguranças patrimoniais; e qualquer problema que tiver, eles vão mediar até eu chegar. Eu tive um problema de um morador jogando entulho no parque, e o segurança pegou o cara e agiu com ele como se fosse o administrador. Trouxe postura, falou de legislação. Quando cheguei eu assumi; e o cara resolveu, tirou o entulho. Porque também se você abre muito, fica muito na amizade, o morador confunde.

CAROLINA: É, isso é um problema, acho que deve ser uma dificuldade para você: ter um trânsito bom, sem perder a autoridade.

FERRUGE: E ter autoridade no parque da periferia é você ser amigo de todos, literalmente de todos.

\section{CAROLINA: É possível?}

FERRUGE: Sim, você tem que ser imparcial. Não é uma receita de bolo, mas funciona por enquanto. Existe tráfico, existe droga, existe crime, existe tudo isso, mas não é problema da secretaria do Verde e do Meio Ambiente. Eu deixo isso muito claro para os caras. Eu não sou da segurança pública, não sou da prefeitura regional, não sou vereador, sou da secretaria do Verde.

CAROLINA: Acho que é um bom posicionamento; isso permite que esse parque exista do jeito que ele é, plural. E o que você faz quando tem tempo livre, se é que você tem tempo livre?
FERRUGE: Eu trabalho muito.

CAROLINA: E você também toca o projeto...

FERRUGE: O projeto social Meninxs da Billings. O projeto é na questão do acesso às águas. A gente trabalha a prática do remo, a prática de educação ambiental, construção naval. Para manter o projeto, eu preciso me relacionar com as pessoas, e as pessoas que gastam e consomem turismo não estão na periferia, elas estão no centro. Então, a gente começa a conversar com essas pessoas, sair, conversar, mostrar o trabalho e uma vez por mês a gente faz essa experiência, essa vivência de remo, que é o Remada na Quebrada. Essa parte aí tá mais parada agora. A gente só tá fazendo o Remada pra comunidade mesmo.

CAROLINA: Uma vez por mês...

FERRUGE: Todo último domingo do mês é certo que acontece, mas geralmente a gente costuma fechar por grupos para não ficar muito oscilado. O Remada na Quebrada atende muito o CCA, que é o Centro para Criança e Adolescente do bairro.

CAROLINA: Então, as crianças vêm...

FERRUGE: Às vezes, por exemplo, pode acontecer no último domingo no mês, mas sexta-feira tem a aula no CCA, e aquele público que viria no domingo, vai vir na sexta pelo CCA com kit-lanche, segurança, transporte.

CAROLINA: Você consegue fornecer essas coisas ou a criançada vem alimentada?

FERRUGE: Isso fica muito solto, quando a gente faz 
por nós, pelo fato de não ter financiamento e não ter recursos, a gente não tem como praticar atividade náutica e dar um kit-lanche. Então, na sexta-feira, a criança vem pelo CCA alimentada. Hoje, o projeto é uma extensão do CCA, do CEU, da Unidade Básica de Saúde. O Meninxs da Billings é uma extensão desses espaços. O que mantém a Billings é o turismo de base comunitária, que é o turismo que a gente faz com as pessoas da cidade. A galera vem, a gente tem alguns barcos, junto com os pescadores a gente faz rota náutica, visita o mirante da ilha do Bororé, visita a Ccasa Ecoativa, vai para outros municípios, sai de São Paulo...

CAROLINA: Sabe que esse domingo vai ter a festa de Nossa Senhora dos Navegantes lá em São Bernardo?

FERRUGE: Que daora, tinha que fazer alguma coisa aqui.

CAROLINA: Tem missa, procissão, cortejo náutico... É num lugar que eles chamam de Prainha, um parque que fica na saída da Anchieta, mas do lado de baixo da barragem, não do lado de cima.

FERRUGE: É municipal?

CAROLINA: Municipal. É uma praia, é muito legal. Esse lugar também faz parte do meu estudo. Falando na Prainha, lembrei que, quando conversei com o Bruno e com o Rodrigo, eles disseram que as crianças se afogam aqui na represa.

FERRUGE: É bem esporádico, não é com frequência, não. Teve um verão 2015, acho, que rolou naquele ano uns três óbitos aqui. Em 2016, aconteceu um aqui nesse terceiro tronco, na terceira base, o cara estava com um cachorro, o cachorro pulou, foi pegar o cachorro, caiu e morreu. O cara adulto já, estudou no EJA, dei aula para ele no EJA. Não sei o que aconteceu...

CAROLINA: Às vezes, a pessoa se desespera...

FERRUGE: Aqui tem um problema muito sério; agora não muito, mas logo quando inaugurou, isso aqui era um ponto de encontro. Então, a galera virava nas baladas e vinha para cá de manhã tomar banho, ou o cara ia para a balada e vinha para cá antes para fazer um esquenta. Era um negócio muito louco, a galera mergulhava, tomava banho, e é isso, às vezes o cara estava alcoolizado.

CAROLINA: Sim, está menos esperto, com poucos reflexos... Para que serve a represa?

FERRUGE: A represa serve para inconscientemente trazer vida para as pessoas, e conscientemente trazer trabalho para os pescadores; trazer lazer para os adolescentes e as crianças; traz paz, calma; traz preocupação e medo; boas lembranças e péssimas lembranças. A represa é um mistério.

CAROLINA: É múltipla.

FERRUGE [cumprimentando Camila]: Oi, tudo bom? CAMILA: Tudo bem?

FERRUGE: O pessoal vai fazer a podagem do parque hoje, tá?

CAMILA: Vai já?

FERRUGE: Vai começar a podar as árvores e, depois, 
na semana que vem, vai fazendo a roçagem, abaixando o mato. É normal, o mato tá grande mesmo, vai crescer em tudo quanto é lugar, no Ibirapuera também tá assim.

CAROLINA: Está mesmo.

FERRUGE: Se você ver a galera e puder dar um toque, porque estão achando que está largado e não é, é que tem uma agenda, eles vêm fazendo a limpeza... Eles têm um cronograma dos parques da cidade, é uma empresa que faz isso, então eles vêm fazendo.

CAMILA: Tinha um pessoal que fazia antes aqui, né?

FERRUGE: Fixo não tem, o que tem fixo é uma pessoa para limpar o parque, que é o seu Lazareno; e tem uma equipe de segurança que é fixa. Lá no Parque do Prainha, como lá tem banheiro, tem as pessoas que fazem a limpeza do banheiro, então a equipe é maior. Aqui não tem banheiro, então é só o seu Lazareno mesmo. E vem a equipe que tem contrato com a prefeitura que, de tempo em tempo, dentro do cronograma, vem um engenheiro agrônomo e fala: "Vai lá porque o mato já tá grande"; ou eu olho e falo, eu sou o administrador, eu falo: "Olha, tá grande, vai lá, vamos criar o cronograma". A gente cria o cronograma, e eles vêm.

CAMILA: E em questão da manutenção da academia, dos brinquedos?

FERRUGE: A manutenção da academia é um ofício que foi encaminhado para a prefeitura regional. O Santiago, que é o prefeito regional, que é responsável. É esse cara que tem que resolver. Isso é bom deixar claro sabe, porque as pessoas acham que é o administrador, e não é. Do outro lado ali, você lembra colocaram um monte de equipamentos ali...

CAMILA: Lembro, mas faz muito tempo isso...

FERRUGE: Aí, arrancaram e jogaram na represa.

CAMILA: Eu não sabia que tinham jogado na represa...

FERRUGE: Isso, aí domingo eu passei ali e vi os mesmos equipamentos todos enferrujados, chumbados, instalados na rua. E eu me perguntei: "Quem foi que fez isso?". Tá tudo ferrado, tudo enferrujado, mas funcionando. Aí, eu parei o carro e perguntei: "Quem foi que instalou isso aqui?". Tinha umas mulheres, e elas falaram assim: "A gente, nós"; e eu: "Como assim?"; e elas: "Nós aqui"; e eu: "Mas vocês contrataram um serralheiro?"; e elas responderam: "Nós, moço, nós que puxamos a corda, tiramos da represa". Elas cavaram, chumbaram, mexeram o concreto. Meu, você precisa ver, um negócio muito louco, elas fizeram a academia delas ali. Elas resgataram os negócios no fundo da represa, mano. Umas seis mulheres e um monte de adolescentes, algumas mulheres mais idosas e um monte de adolescente. E elas fizeram a academia delas. Não estou comparando, mas só para entender que aqui nós temos equipamentos, mas eles foram quebrados e não dá para fazer manutenção. Já trouxe o serralheiro, e ele falou: "Isso aqui não dá para consertar, tem que trocar". E para fazer essa troca com quem que é? Com a prefeitura regional, o prefeito regional que faz essa troca. Foi mandado um ofício.

CAMILA: Aí, eu tenho que ir lá na...

FERRUGE: Na prefeitura regional e falar: "Olha, a 
gente está solicitando os equipamentos para o parque, foi entregue um ofício, vocês não deram feedback".

CAMILA: A dona Vera postou uns negócios bem...

FERRUGE: A dona Vera está arrebentando, fazendo abaixo-assinado para me tirar do parque. Eu não estou preocupado porque isso aqui é uma sequência, as coisas vão acontecendo, o mato vai crescer mesmo, o equipamento de ginástica foi mandado o ofício. A ponte que foi feita ninguém posta.

CAMILA: Não é só culpa sua, é também de quem não cuida.

FERRUGE: É, você viu a ponte? Ela não está pronta, mas estão fazendo a ponte, vão concluir o trecho dois do parque na Gaivota lá na rua São Dias. Então, se você encontrar ela, fala: "Olha, tem umas coisas que estão acontecendo, posta as coisas que estão acontecendo boas". Ontem à noite, o parque estava lotado, uma da manhã e o parque lotado. Eu estava no parque, peguei a bicicleta vim pedalar; e o parque lotado. A galera suja, é normal, você vai parar para trocar ideia, e o cara tá bêbado.

CAMILA: Mas o pessoal também tem que ter consciência, jogar lixo no lixo, já vi várias vezes...

FERRUGE: Entendeu? Você viu as lixeiras de pet? A galera das casas está tirando lixo das casas para colocar nas lixeiras, a galera desce lá de cima para colocar lixo aqui, o lixeiro não vai coletar esse lixo, quem vai pegar esse lixo é o seu Lazareno, tá entendendo?

CAMILA: E tem que fazer a manutenção daqui [re- ferindo-se ao píer], não só por conta do pessoal, também por conta da água que vai ficando...

FERRUGE: Isso daqui, por exemplo, já é contrato. Os caras tem que abrir uma licitação, a empresa vir aqui e passar seladora, verniz, trocar as madeiras podres. Enfim...

FERRUGE: E você sabe o porquê desse cheiro?

CAMILA: Não.

FERRUGE: Esse cheiro é por conta desse mato que fica encostado na borda. A represa diminui o nível, e ele sai da água. E ele consumiu poluição, ele filtrou. O sol vem e começa a soltar isso. Se você vier com um isqueiro ali, tem lugar que é perigoso pegar fogo, porque libera gás. Esse mal cheiro é isso. Tem um vazamento de esgoto da Sabesp lá na frente, eu tirei foto e liguei para o cara da Sabesp, mas a Sabesp não é o parque, a Sabesp é a Sabesp. Então, esse problema da Sabesp é um negócio coletivo, eu liguei lá, daí ela liga, você liga, todo mundo liga; aí a Sabesp vem aqui e bombeia esse esgoto. Estou falando para você, porque eu sei que você é bem ativa, está sempre na comunidade e tal. Ah, domingo três da tarde, vamos fazer um mutirão lá no Arco, a gente vai vir do Arco para cá.

CAMILA: Domingo.

FERRUGE: Domingo, se quiser encostar e chamar a dona Vera também.

CAMILA: Ahã, ela está...

FERRUGE: Eu não vou chamar, porque ela está desse jeito aí. Se ela quiser colar você avisa: "O Ferruge 
vai fazer um mutirão lá para limpar o parque com a galera". Porque não adianta fazer um mutirão hoje, tem que fazer mutirão no dia que está muvucado. Ontem à uma da manhã eu não ia fazer mutirão.

CAMILA: E o negócio do final do ano, que depois de uns dias eles soltam fogos aqui. Nem teve, e o pessoal estava esperando a queima.

FERRUGE: A queima, né? A gente fez a distribuição dos brinquedos do Papai Noel, você sabe?

CAMILA: Eu vi, eu só não fui pegar porque as crianças já tinham ganhado também.

FERRUGE: Mas tem alguns, se quiser pegar pras crianças...

CAMILA: Não, não. Aí, eu ia trazer as crianças para ver, ia ser a primeira queima de fogos deles aqui, ai não teve.

FERRUGE: Tá bom, se puder dar um toque nela... Mas, enfim...

CAROLINA: A gestão de um parque metropolitano não é fácil, porque são...

CAMILA: Ainda mais na comunidade... É sempre por último.

CAROLINA: E como ele falou, são muitas variáveis. Tem uma empresa que é de saneamento, tem uma empresa que é de manutenção...

CAMILA: É tudo terceirizado e tem que esperar o governo dar uma assinatura, tudo à base de assinatura e à base de contrato para poder liberar.
CAROLINA: O nosso papel é pressionar os governantes, porque sem pressão não vai.

CAMILA: Não vai.

CAROLINA E FERRUGE: Se unir, tem que se unir.

CAMILA: Vieram com pressão para eu trabalhar aqui; pegar e gerenciar; e eu não peguei. Não peguei porque ele faz e ao mesmo tempo não. Queria me pagar e eu falei: "Não quero". E eu nem vou porque se eu for me envolver eu desço lá e faço parte mesmo. Hoje, o pessoal estava pedindo para eu ir lá fazer abaixo-assinado da perua. Já foi feito um abaixo-assinado e queriam refazer porque tem muita gente que às quatro da manhã tem que pegar aqui...

FERRUGE: E tem que subir para lá.

CAMILA: No fim de semana, tipo no sábado, no sábado o pessoal trabalha também.

FERRUGE: E não tem. Tem que subir para lá. Eu acho que isso é legítimo, tem que ter sim.

CAROLINA: Qual que é a história?

FERRUGE: É que ônibus só entra no bairro de dia de semana.

CAMILA: Em certos horários.

FERRUGE: Daí, a galera que trabalha de sábado tem que ir lá para a avenida, lá em cima.

CAROLINA: Nossa, tem que andar muito. 
CAMILA: Tem que andar até a avenida. E agora o ponto não é mais aqui, é em cima, então piorou.

FERRUGE: Ao invés de ajudar, piorou.

CAMILA: O ônibus só roda de segunda à sexta, das quatro da manhã às nove da manhã; depois para; aí só volta às quatro da tarde até à meio-noite. Se tá um sol desse, e a mãe quer levar o filho no médico, tem que ir até lá em cima; é uma caminhada. Se não fosse o bequinho ali que passa do Cantinho do Céu pro Lago Azul... E mesmo assim ali é arriscado, porque esses dias uma senhora quase caiu ali. Quem mexe ali é o seu Milton.

FERRUGE: Que cria os porcos ali.

CAMILA: Ele que limpa, ele que coloca madeira para o pessoal pisar.

CAROLINA: Ah, ele que tem uma chacarazinha?

CAMILA: É.

FERRUGE: Ali vai ser o trecho cinco do parque, a última etapa.

CAMILA: Que vai ser para poder entrar no Cantinho do Céu e...

FERRUGE: Isso, é a última etapa do projeto. Ali já é oficial, a população já se organizou, tinha que ter uma ponte mesmo, tubular...

CAROLINA: Quando tiver o parque vai funcionar, mas até o parque existir vai levar um tempo.

CAMILA: Aqui é um lugar que eu moro desde criança, é um lugar maravilhoso. Se você soubesse como eram essas ruas aqui de baixo... Antigamente, o meu pai tinha que pôr sacolinha de lixo no pé pra poder subir, porque ele trabalhava em hospital, pra poder subir até a avenida para pegar um ônibus.

CAROLINA: Que loucura.

CAMILA: Melhorou muito, mas têm muitas coisas ainda para melhorar. Eu jogava bola no barro.

CAROLINA: Você jogava bola? Que legal.

CAMILA: Jogava bola, vôlei, na chuva, no barro.

CAROLINA: Demais. Quer dizer, legal que você sempre teve esse uso da margem, mas obviamente temos um parque agora.

CAMILA: É, agora tem o parque.

FERRUGE: É muito louco, se você visse ontem como estava aqui ontem a noite, muita gente. $\mathrm{O}$ Arco estava lotado, isso aqui estava o maior fluxo. A gente pediu para a Lumi vir aqui, estava sem luz aqui e a Lumi trocou, agora tem luz, teve trechos que estavam sem...

CAMILA: Quando tem evento ali de hip-hop ou então pipa-combate o pessoal vêm mesmo.

CAROLINA: O que é o combate?

CAMILA: Pipa-combate.

CAROLINA: Pipa-combate, mas é de empinar pipa?

FERRUGE: É. 
CAROLINA: Que legal.

CAMILA: Aí faz sorteio de pipa, e tem que ter essas coisas aqui, senão o pessoal...

CAROLINA: A molecada precisa de atividade.

CAMILA: Precisa.

CAROLINA: Você tem filhos de que idade?

CAMILA: Uma de nove e um de três.

CAROLINA: Esse de três, que ainda é pequeno precisa...

FERRUGE: Gastar energia.

CAMILA: Ele é 24h, correndo, pulando, eu sempre trago, o pai dele traz. Ele tem que correr, andar, porque senão ele chega em casa e nem dorme.

CAROLINA: É isso, ele precisa gastar energia para dormir bem.

CAMILA: Ela anda de bicicleta...

CAROLINA: Aqui é gostoso, eu vejo a molecada andando, bem gostoso. Qual é o seu nome?

CAMILA: Camila.

CAROLINA: Carolina.

FERRUGE: Pois é então, domingão a gente vai estar por aí.
CAMILA: Antigamente, eu ajudava mais. Ajudei muito a dona Vera, mas hoje em dia eu dei uma desanimada.

FERRUGE: Acho que tem que ser dosado, né? Tem que ser igual, por exemplo, o Willian é um cara que mora perto do Arco, ele que faz essas lixeiras, fez umas 15 lixeiras dessa, e foi continuando. Enfim, virou uma terapia, mas é algo que ajuda bastante o parque, óbvio. Mas é dosado sabe, ele faz no tempo dele, pô beleza, se cada um fizesse um pouquinho, já era. É igual ontem lá no parque, lotado, se você chegar sozinho e falar com o cara, nem rola. Mas se chega seis ou sete: "Não joga lixo, não", vira cultura, é cultural. Vou tirar esses galhos aqui agora, os caras estão chegando com caminhão para retirada.

CAROLINA: Posso continuar fazendo umas perguntinhas? Vou continuar aqui, ta bom. Camila? Foi um prazer conhecer você.

CAMILA: Prazer também.

CAROLINA: Quais são as turmas que frequentam o parque, Ferruge?

FERRUGE: O parque é linear, então o uso é bem mesclado. De manhã, tem um público enorme, uma quantidade maior de pessoas que frequentam que são os idosos, das seis da manhã até aproximadamente oito, nove, são idosos. Aí, nove, dez, chega a molecada, na grande maioria é molecada que estuda das sete às onze que não foi para a escola; eles cabulam e vêm para o parque, isso acontece com frequência, é uma molecada de 12, 13 anos. Meio-dia, o parque para, não tem uma alma na rua. Às três da tarde, começa a galera, adolescente que vêm depois da escola. Ai, às sete horas, começa a 
vir um público, maioria de adolescentes; e umas nove, dez chega o público adulto, a galera adulta chega do trabalho, chega em casa e toma um banho, pega o carro e vem para o parque, liga um som, fica curtindo e bebendo no parque.

\section{CAROLINA: Bem eclético.}

FERRUGE: Isso, e é interessante que tem os horários, os idosos vêm de manhã; à noite, a galera que trabalhou o dia inteiro e quer curtir um som ou fazer o esquenta da balada.

CAROLINA: Amanhã, talvez seja um dia bom para eu vir... Sabe que eu levei um susto outro dia, vi alguma coisa saindo da água, e e pensei: "Não pode um ser peixe", quando fui ver era um...

FERRUGE: Irerê, a galinha d'água.

CAROLINA: A galinha d'água?

FERRUGE: Com o biquinho vermelho, isso aí dá uma cadeia, meu. Se você pegar isso aí, e o guarda civil pegar, já era.

CAROLINA: Mas pegar para quê? Para comer?

FERRUGE: Tem gente que pega, tem gente que caça, tem gente que leva: "Ah, vou levar para criar na fazenda". É crime ambiental. É o frango d'água. Teve um cara que tinha uma chácara, alugava a chácara pra casamento; foi pegando um monte, colocando num laguinho lá. E o pessoal falando: "Olha que bonitinho, vamos tirar foto". Aí, num casamento, um dos convidados era guarda civil ambiental. "E esses irerês aí?", "Ah, são os frangos d'água que eu estou criando", "Faz tempo?", "Uns dez anos já", "Então, são dez anos que você está cometendo um crime, tá preso". Levaram o cara, ideia vai, ideia vem, não era só um guarda, era uma galera que tava lá. Todo mundo, inspetor e tal. Não tinha como passar um pano pro cara.

CAROLINA: Ah, genial... Você tem lembrança de quando você era pequeno e veio pra cá? Quando seus pais vieram para o Cantinho, quantos anos você tinha?

FERRUGE: Ah, 1990, 1989, eu devia ter uns oito anos.

CAROLINA: E como era nessa época, você vinha para a represa?

FERRUGE: Tinha o lance do medo: "Olha, não vai pra represa, lá é perigoso". Então, a gente ia escondido; tudo era escondido. Toda vez que eu saia de cueca branca, eu apanhava porque quando chegava à noite minha mãe via a cueca marrom de barro. "Foi pra represa?!" Chicote.

CAROLINA: Você é filho único?

FERRUGE: Não. Quer dizer, do primeiro casamento, sim. Minha mãe casou de novo, e eu tive mais dois irmãos, eu sou o mais velho. Então, era um negócio proibido, a represa era proibida. Na adolescência, já foi mais tranquilo, cabulava escola, ia para a represa, tomava banho.

\section{CAROLINA: E as meninas também vinham?}

FERRUGE: Não, menina não, era raro. Então, a gente pegava bicicleta, atravessava a balsa; a balsa era proibida também. Meu pai falava: "Vai pra tudo quanto é lugar, mas não atravessa aquela balsa". 
Porque não tinha nada, você atravessava a balsa e não tinha mais nada lá, era só mato. Eu lembro que tinha um cara na minha rua chamado Mazinho. E o Mazinho falou de reunir uma galera, domingo às duas da tarde, vamos pedalar. Beleza, saiu uns trinta moleques. Eu falei: "Pai, deixa eu ir, é ali do lado, no Eliana, rapidinho", "Tá bom, não demora, hein?". Peguei a bicicleta, e o Mazinho: "Vamos atravessar a balsa", e eu: "Vamos". Estou com o Mazinho, o Mazinho é o mais velho do bagulho, é filho do seu Louro, o seu Louro é dono do time de futebol, e o bar do meu pai é a sede do time de futebol; então, tá tudo em casa. Aí, atravessamos a balsa, e a segunda balsa, compramos peixe e comemos. Voltamos. Quando chegou na hora de atravessar a primeira balsa, a balsa quebrou.

\section{CAROLINA: Ai...}

FERRUGE: O cabo da balsa estourou, e já era. A Emae era a maior enrolação. Não é igual a hoje que você faz um barulho ali e já vem. Era muito dificil, demorou horas.

CAROLINA: E não tinha celular, Whatsapp...

FERRUGE: Não tinha celular, Whatsapp. E aí o que aconteceu, a gente nem viu o tempo passar, porque a gente andava de bicicleta, e na época era BMX, bike de manobra. Então, juntava cinco, seis moleques: "Deita aí que eu vou pular vocês". E todo mundo lá na balsa assistindo, porque ela estava quebrada e não tinha nada para fazer. E eu, pá, pulava os moleque, e todo mundo: "Aehh!!". Colocava um bloco, o outro vinha e fazia uma manobra, todo mundo brincando de bicicleta. E aí cinco, seis, sete, oito, nove horas da noite. Cheguei em casa e tomei um pau. Eu e o Mazinho. Meu pai me pegou; e o Mazinho: "Não, ele tava comigo!", e meu pai: "Vem aqui você também, seu pai vai te matar, mas antes eu te pego". É a história da balsa.

CAROLINA: Você tinha que idade?

FERRUGE: Devia ter uns 10, 11 anos. Com 12, 13 já estava dando baile no Washington.

CAROLINA: Tem alguma outra história da represa?

FERRUGE: O contato com a represa mesmo, de barco, náutica, eu tive mais com os amigos depois de adulto, com a família. O meu compadre de casamento, fui padrinho dele, tinha uns caiaques. A gente ia pra represa andar de caiaque.Tinha outros amigos. do Cocaia, na estrada da ligação, que também tinha caiaque. mas era raro porque é caro. Era uma coisa que não era um esporte, era um negócio. "Ah, o cara tem um caiaque; legal!", mas eu nunca imaginava comprar um caiaque, como você ia levar um caiaque na represa? Não tinha entrada na represa, o único lugar que você tinha: "Vamos na represa?", na balsa; "Vamos tomar banho?", na balsa. Não dava pra entrar no fundo da casa de um amigo para ir na represa, porque era esgoto. As pessoas não valorizavam, não olhavam para a represa da forma que a gente olha hoje. De dez anos para cá que o olhar é outro para a represa.

CAROLINA: E, nesse sentido, você acha que o parque teve um papel importante?

FERRUGE: Fundamental, o parque mudou a realidade daqui. Não é jabá, é sério, mudou mesmo. O parque foi feito, e as pessoas começaram a reparar mais, tanto para o bem, tanto para o mal. Todo mundo vem andar, caminhar, praticar esportes, 
tomar banho, usar drogas, beber, tudo aqui.

CAROLINA: Democrático.

FERRUGE: Acontece de tudo, mas o bom daqui é que é tudo com moderação. Nunca teve um problema de assassinato, roubo, nunca falaram: "Me roubaram no parque". Lá em cima na avenida, sim; no parque, nunca roubaram ninguém. O bandido veio aqui tirar lazer: "Hoje aqui eu não roubo não, estou suave, tá daora, o parque é muito bom".

CAROLINA: Todo mundo respeita.

FERRUGE: Tem gente que vem de Parelheiros pra cá. O cara que não é flor que se cheire, o cara veio pra cá porque aqui é muito louco. "Pô, Ferruge, daora." Traz cooler, cervejinha, de moto, depois sai fora. E sabe que os terrenos mais baratos na época eram os da represa. "Ah tem um terreno bom ali", "Você não tem um mais barato?", "Tem, um lá embaixo na represa, vou quebrar seu galho". Mal sabia que era para ser o mais caro.

CAROLINA: Imagino que as casas são as mais valorizadas hoje.

FERRUGE: Sim, na lha de Bororé, por exemplo, pedágio perto da água é mais caro. Engraçado, né?

CAROLINA: Tem o potencial da água, uma relação de lazer com a represa.

FERRUGE: Na verdade, o foco dessa região é essa especulação imobiliária. O cara vinha aqui para comprar casa, vender terreno e ponto. Nenhum grande empresário veio montar clube, ninguém pensou nisso. Não teve um cara para falar: "Meu, onde você trabalha?", "Trabalho em São Bernardo", "Sabia que você pode ir de barco para São Bernardo? E economizar uma hora e meia do seu dia?". Você poder fazer uma academia. Mas o pessoal parece que não quer, não fazer nada mesmo. Sabia que tem gente que até hoje, tem 15 anos o CEU, e tem gente que acha até hoje que o CEU é pago para entrar.

CAROLINA: É que é um equipamento tão sofisticado, tão imponente que, talvez, a pessoa se intimide.

FERRUGE: Mas é do lado da casa dele, não parou para ir lá ver. Nunca entrou no teatro, como assim, meu? Um teatro com 450 lugares, primeiro mundosabe. E acho que hoje estamos criando outra geração bem complicada. Se você for parar para analisar, eu que estou muito mais no bairro, então eu estou observando isso, a geração é isso, eles ficam o dia inteiro em casa ou estudam, e à noite eles vêm para o parque, aí ficam até duas, três, daí vai dormir, dorme até meio-dia, aí vai para a escola... Não é igual à minha geração, a minha geração era acordar cedo e ir trabalhar, sem massagem. E é porque hoje é a geração do Netflix, pai trabalhando a milhão, tem Netflix em casa, está suave, tem internet em casa. Aí, o sol dá aquela amenizada: "Ah, vou pro parque".

CAROLINA: Não sei se dá para julgar se é bom ou se é ruim. É diferente.

FERRUGE: Mas é uma análise.

CAROLINA: Vir ao parque só à noite não significa, necessariamente, que o dia foi perdido.

FERRUGE: Acho que precisa gerar conteúdo nesses espaços. 
CAROLINA: Sim, aí eu concordo com você.

FERRUGE: Não adianta ter o espaço e não ter nada nele, aí abre margens pra tudo que não presta.

CAROLINA: Alguém vai gerar o conteúdo...

FERRUGE: A maioria das lixeiras que você está vendo aí, é feita com garrafas pet de vinho que a galera deixa no parque.

CAROLINA: Aquele vinho chapinha?

FERRUGE: Cantinho do Vale.

CAROLINA: E o negócio com a Red Bull, como foi? Eles vieram até você?

FERRUGE: A Red Bull procurou o parque. Eles mapearam todo o espaço, viram que tinha uma pista de skate, a pista estava com algumas rachaduras no concreto; e eles fizeram a proposta: dar uma manutenção no espaço. Aí, nós fizemos a parceria, um dia de reparo, de mutirão, para colocar a mão na massa. Quem fez o reparo no concreto foi a InsaneHemps, que é uma das empresas de construção de pistas de skate da Red Bull. O festival Amaphiko foi um evento maior, com apresentações de cultura, empreendedorismo e tal. Essa ação pontual no parque foi um extra, um bônus que a Red Bull falou: "Vamos fazer, tem uma pista lá, vamos fazer".

CAROLINA: A maior parte do festival foi no centro cultural, não foi?

FERRUGE: É, no centro cultural. Nós fizemos um encontro no parque. No dia da inauguração, veio o Sandro Dias, o Mineirinho, mas antes rolou esses mutirões. Não houve uma mudança estrutural do parque, e a secretaria do Verde teve ciência da ação, mas não teve uma mudança, não foi preciso redesenhar a pista.

CAROLINA: Foi uma manutenção, como se tivesse feito uma pintura...

FERRUGE: Sim, só foi colocado uns obstáculos a mais, ficou legal.

CAROLINA: Eu vi. A galera que estava no dia estava muito felize, de certa maneira, orgulhosa: "Olha que demais um evento como esse aqui".

FERRUGE: Foi incrivel.

CAROLINA: Foi o reconhecimento do parque como lugar para eventos daquele tamanho.

FERRUGE: Agora, o que a gente pensa é em retomar essas ações, trazendo mais essas atividades para a pista; fomentando a escrita de projetos para editais partindo dos skatistas, fazendo com que eles captem recursos e toquem projetos. Não dá pra ficar esperando o salvador chegar.

CAROLINA: Talvez para os skatistas isso seja uma novidade, mas os líderes de comunidade sabem bem como fazer isso. Quais são os coletivos que usam o parque?

FERRUGE: São vários coletivos que dependem desses editais, poucos funcionam com autonomia. No Meninxs da Billings, exemplo, a gente não quer depender de recurso de edital, a gente quer depender do nosso trabalho. O Meninxs da Billings é 
um negócio social, não é uma empresa, mas a gente vende turismo náutico, é isso que dá o sustento para pagar as contas até vir o edital. A gente se inscreveu na NIP, que é uma aceleradora de negócio de impacto na periferia; tivemos uma parceria com a Via Varejo para desenvolver uma oficina de marcenaria e uma oficina de reconhecimento de território pelas águas. Daí, nasceu a UniGraja, e estou correndo para mais ações esse ano. O Meninxs da Billings está dentro da UniGraja, que é um conjunto de dez coletivos, cada um propondo sua matéria para a Universidade Livre do Grajaú. A nossa matéria é a primeira da faculdade: reconhecimento de território e vivência de marcenaria. São vários coletivos, e cada um atua numa área: permacultura; náutica com remo; tem coletivo que trabalha com barco a vela; tem coletivo que trabalha com arte, pintura e grafite. Assim, a gente vai criando essa relação de parceria.

CAROLINA: Todo mundo se conhece.

FERRUGE: Sim, todo mundo se conhece, abriu um edital, alguem avisa: "Tem a ver com você, se inscreve ai".

CAROLINA: Tem algum coletivo de meninas?

FERRUGE: Tem o Grajaminas, que é um grupo de cantoras; tem o Sarau das Minas, de artistas independentes; tem a Denise Alves, várias artistas e cantoras.

CAROLINA: No tempo que eu passo no parque, eu vejo sempre muito mais meninos que meninas.

FERRUGE: No Meninxs das Billings têm muita mulher que põe a mão na massa. Na verdade, é a maioria.

CAROLINA: Outra coisa: a galera chama o pier de
"T", é isso?

FERRUGE: É, não sei de onde surgiu a ideia, todo mundo sabe que é "pier" o nome, mas acho que nos próximos trechos do parque, a galera já vai estar mais familiarizada.

CAROLINA: Mas você vê que tem o formato de um T? Eu acho curioso, acho genial, na verdade.

FERRUGE: É, mas ninguém chamaria isso de " $T$ " em Ilhabela: "Vamos lá no T". Não, né? "Vamos lá no pier flutuante."

CAROLINA: E tem um outro lugar que chamam de "a câmera".

FERRUGE: Ali na curva do vento, a câmera da guarda civil, né?

CAROLINA: É. Você sente falta de uma sede aqui para o parque?

FERRUGE: Não, porque infelizmente na periferia existe essa cultura do assistencialismo, essa questão: "Ah, é culpa do fulano, fala com o fulano". Pra você ter uma noção, quando eu assumi o cargo, todos acharam que eu virei o presidente do bairro Tudo que era problema, de energia, o gás da casa da mulher faltou, era: "Fala com o Ferruge". Se você tem uma sede, acaba virando um ponto de lamentações. A base dos guardas tem meu telefone disponível. Eles são autorizados a passar meu telefone para qualquer pessoa, porque eu quero saber o que está acontecendo, eu quero entender, se a gente vai resolver ou não já é outra história.

CAROLINA: E você acha que precisaria ter mais 
gente na equipe?

FERRUGE: Deveria aumentar a equipe de segurança, e deveria ter um ponto de apoio do Corpo de Bombeiros, não de uma empresa terceirizada, do Corpo de Bombeiros do Estado. Tem que ter um barco disponível 24h para fazer salvatagem, tem que ter uma casinha para o salva-vidas. Isso faz falta. Com isso, você acaba legitimando o uso do píer, o cara vai ver que tem salva-vidas e vai ficar mais tranquilo.

CAROLINA: Até porque o pier não tem guarda-corpo. Se uma criança vem correndo, ela cai na água.

FERRUGE: Eu comprei um kit de salvatagem. Deixei bem claro aos moradores que existe esse kit na guarita; é um colete salva-vidas, uma boia e um cabo de 15 metros. Se alguém precisar, é só correr lá e pegar.

CAROLINA: Isso pode ajudar, claro.

FERRUGE: A pessoa consegue se salvar, se estiver consciente.

CAROLINA: Você acha que há pessoas que usam este espaço melhor que outras?

FERRUGE: Não, acho que está no processo ainda. As pessoas não acordaram ainda, ainda não teve um cara que falou: "Vou comprar um barco". O cara vem, ele olha, é muito bonito e depois ele volta para a realidade, porque a realidade do bairro, a realidade do Grajaú é muito parecida com a realidade de outros bairros de periferia. O cara vem para cá e descansa. Então, ele não tem tempo, o tempo dele é para pensar no trabalho dele, na faculdade, na escola, ele tem que pagar as contas, ele trabalha todo dia, acorda de madrugada, vai e trabalha, pega trânsito, demora duas horas para chegar no serviço, trabalha, volta, duas horas, vem quebrado; chega em casa ele quer tomar um banho e dormir. Então, ele só vai observar a represa no domingo, se não tiver jogo do Corinthians. Se tiver, ele vai ficar em casa. Aí, ele vem para cá com a mulher, passeia um pouco, olha a represa, se sente bem e segunda-feira começa de novo.

Marcos Ramos, Enivo, 36 anos, Artista Plástico, grafiteiro, curador, galerista, morador do Grajaú até os 18 anos

CAROLINA: Bom, eu sou a Carolina e estou fazendo uma pesquisa de mestrado na área de paisagem e ambiente, que é o ramo que estuda o paisagismo na arquitetura. Como minha pesquisa é sobre a represa Billings, eu escolhi duas áreas que me parecem muito interessantes: o parque linear do Cantinho do Céu e a Prainha. São duas áreas usadas para o lazer, o que também é um dos recortes da minha pequisa.

ENIVO: Desculpa, Prainha?

CAROLINA: A Prainha fica no Riacho Grande, em São Bernardo.

ENIVO: Achei que era a do Grajaú.

CAROLINA: Não. Minhas áreas de pesquisa são a Prainha, de São Bernardo, e o Cantinho do Céu. Minha ideia é focar na narrativa das pessoas que conviveram e convivem nesses espaços, por isso, eu tenho feito várias entrevistas.

ENIVO: Legal. Você já entrevistou o Mauro? 
CAROLINA: Ainda não.

ENIVO: Ele chega dia 13, daí você pode falar com ele. Ele é o Imargem, né, então tem tudo a ver. O projeto dele é muito forte, eu faço parte desde o começo, e já fiz muitas coisas com ele... É o cara.

CAROLINA: Ele criou o Imargem, certo?

ENIVO: Exatamente, as ações lá são meio especiais.

CAROLINA: Vocês moram e trabalham aqui?

ENIVO: Moramos aqui eu, o Snix e o Mauro.

CAROLINA: O Mauro, então, brevemente estará aqui de volta.

ENIVO: Semana que vem, é. A gente viaja, e ele volta.

CAROLINA: Vocês vão para onde?

ENIVO: O Snix vai para o Japão, e eu vou pra Orlando.

CAROLINA: Vai a trabalho?

ENIVO: Quero dar um rolê e ter um tempinho livre até para poder pintar alguma coisa. Mas vai ter uma programação lá, vou conhecer uns lugares. Aí, depois, eu vou pintar aqui.

CAROLINA: Bom, eu me apresentei, queria que você se apresentasse também; contasse um pouco sobre você e sobre seu trabalho.

ENIVO: Eu sou o Marcos Ramos, o Enivo. Sou artista plástico, grafiteiro, galerista, curador, faço várias coisas relacionadas à arte. Eu nasci no Grajaú, cresci lá, morei lá até os 18 anos; depois, me mudei para Interlagos, onde minha mãe mora hoje. Desde 2008, estou aqui na região da Aclimação. Sou graduado em Artes Visuais pela Faculdade Paulista de Artes, me formei em 2006. Em 2008, fundei junto com os amigos o Coletivo 132, que posteriormente, em 2012, deu origem à Sétima Galeria, que fica na Vila Madalena. Eu sempre atuei em movimentos plurais, né, envolvendo pessoas e coletivos, fazendo pontes e intercâmbios. Pontes mesmo, reais, entre ricos e favelados, entre colecionadores e artistas. Descobrindo também as coisas, porque eu venho de quebrada, da periferia, então, tudo é uma descoberta; o que a gente passa... Tem que transpor mesmo. Ser sócio de uma galeria de arte, que é uma coisa vista com tanto glamour por tantas pessoas, vem de uma experimentação que era o Coletivo 132. Ser o que a gente é, e querer mostrar para as pessoas. Então, isso é uma identidade interessante da Galeria Sétima, porque ela é visitada por todos, vai gente lá de todas as zonas, de todas as periferias. Então, é um lugar visitado por todas as castas, todas as classes, e isso me deixa muito feliz. A Sétima influenciou outros lugares na periferia, como a Favela-Galeria, que tem o pessoal do Opini, lá da Vila Flávia. Eles fizeram uma galeria linda. E sempre nessas trocas.

CAROLINA: Por isso é legal fazer essas entrevistas, porque eu vou descobrindo muitas coisas.

ENIVO: Então, as atividades que eu faço têm sempre essa ligação com as periferias, de ir ao mundo e voltar para a mesma origem com novas informações. Sempre com essa cultura, sempre somando com essa irmandade que a gente tem de uma família mesmo, principalmente lá no Grajaú. Eu vou destrinchando, tá? 
CAROLINA: Não se preocupe. Quero fazer algumas perguntas sobre sua relação com a represa, mas não tem nenhuma ordem.

ENIVO: Eu já posso falar da minha relação com a represa. Eu morei a cerca de um quilômetro da represa, morava no Jardim Eliana. Tinha vários braços da represa lá... Então, eu morava ali na frente do campo de futebol, na Rua Clarissa, onde eu cresci.

CAROLINA: É que são tantos campo de futebol...

ENIVO: É um que chama Bola Branca, perto da favela do Sucupira. Então, eu cresci ali, e dava para ir a pé para a represa. Tenho muitas lembranças de lá. Meu tio, Walter, sempre me levava para passear em vários braços da represa. Então, eu tenho essas memórias. Tem uma igrejinha lá na frente, aquela cruz... São coisas que eu tenho muito marcadas na memória. Foi nessa parte da represa também que, em 2003, a gente perdeu o Niggaz, que era um artista muito importante para a gente.

CAROLINA: Eu queria entender um pouco mais essa história.

ENIVO: Ele faleceu ali nas águas, em 2003, afogado. Então, também se torna marcante esse lugar, que deu origem, em 2007 ao Imargem, aí o Mauro vai poder destrinchar melhor isso aí. Foi o que propagou das águas, né?

CAROLINA: Uma elaboração sobre o que aconteceu...

ENIVO: O Tim é pra mim o grande cérebro do
Imargem. Em todos os projetos do Mauro, o Tim é o cérebro, e o Mauro é a cara. Mas eu sempre vejo o Tim como atuante em tudo.

CAROLINA: A irmandade.

ENIVO: Exatamente. Então, isso ali na região da balsa; e tem o outro braço que se pegar o arco de onde eu morava, as mesmas distâncias, que é o Canal do Cocaia, que já era um lugar que eu sempre via como muito degradado, a construção lá foi muito avançada, avançaram muito para as beiras, então sempre tinha bicho morto, cavalo morto, gente morta. Ali embaixo, era uma rua mais densa. O Cocaia mesmo, no final dos anos 1980 e começo dos anos 1990, era realmente... Cocaia, Sipramar, Lago Azul, o que é hoje o Cantinho do Céu, o parque linear, ali no Lago Azul, era floresta. Meu tio me levava para passear lá; era floresta, não existia casa nenhuma, era mata fechada.

CAROLINA: Isso em que ano?

ENIVO: Eu era muito pequenininho, e nasci em 1986. Devia ser 1991, por aí, 1990.

CAROLINA: Praticamente ontem, se a referência for o crescimento das cidades.

ENIVO: É, mas 20, 25 anos atrás não existia Parque Residencial Cocaia, que hoje é muito maior do que o Jardim Eliana. Hoje tem banco, tem tudo lá, mercado, Marabraz, Casas Bahia... E era a vista que eu tinha da minha janela, e era uma floresta. Então, eu acompanhei esse processo de desmatamento e crescimento de um bairro. Essa é uma memória que eu tenho de infância... Da minha laje, que era em uma parte muito alta, dava para ver até o Pico do Jaraguá, 
que fica atrás do Cocaia. Eu vi toda essa migração: mata, barracos, casinhas, casões e a cidade que é hoje em dia. É muito louco. Curioso, também, que talvez possa ser uma pessoa legal para você falar dessa visão, é o Mmoneis, um MC lá do Grajaú, da beira da represa. Ele cresceu na beira da represa, e ele mora na casa que eu cresci.

CAROLINA: Quer dizer, você saiu de lá, foi pra Interlagos, e a família dele...

ENIVO: É. Aconteceram mil coisas na vida, mas de um ano e meio para cá deu um start na minha cabeça, e eu convenci a minha mãe a vender pra ele a casa.

CAROLINA: Entendi. Não é que ele foi morar lá por acaso.

ENIVO: Não. É uma pessoa que eu acredito no talento dele, acredito na caminhada dele, constituição de família, tudo que ele almeja. E ele queria comprar no Cantinho do Céu, lá no fundo, onde estavam uns lotes vendendo... Ele quase caiu numa cilada, dessa gente que vende um lugar que...

CAROLINA: Sim, ali o que mais tem é cilada.

ENIVO: E não tinha nem asfalto na rua. E ele sonhando em dar entrada num terreninho. Aí deu esse link, e ele foi pra lá, essa casa maravilhosa que ele mora hoje.

CAROLINA: Houve um evento da Red Bull, aquele festival Amaphiko, em que um dos módulos foi a recuperação da pista de skate...

ENIVO: Eu pintei. Eu e uns amigos. Aí, teve show do
Mano Moneys...

CAROLINA: Sim, e quem mais fez o show?

ENIVO: Teve também o Slim e o Semblantes, o Luiz Semblantes. A gente pintou lá, fez um grafitão bem louco, foi lindo, especial. Então, ali era essa floresta que a gente caminhava. E tinha todos esses braços. Era Lago Azul, Beira-Mar, os mesmos pontos, né, Prainhas, Cantinho do Céu. Está tendo desocupação por lá agora, quebraram todas as casas.

CAROLINA: A desocupação é sempre um processo bem traumático.

ENIVO: Exatamente. Tem vários processos, famílias que já estavam lá há 20 anos e perderam suas casas e ganharam um cheque de, sei lá, oito mil, na época. Agora não sei como está. Tem pessoas que também chegaram depois e sacaram qual que era...

CAROLINA: E se aproveitam da situação.

ENIVO: É, chegam ganhando o mesmo cheque. Constrói meio mal, pá, derruba; depois, voltam, uma outra família ou alguém linkado, constroem para ganhar um cheque. E fica nessas de constrói, desconstrói. E ganhando esses cheques. Tem várias coisas aí...

CAROLINA: É uma loucura.

ENIVO: E aí que vem essa ligação do pintar ali, fazer um mural grande ali, apresentando o negro, apresentando o Caio, que é uma pessoa que talvez você pode querer falar também, é um menino, artista demais. Um menino supertalentoso, e fiz aquele retrato, por isso dediquei a ele. Já era uma releitura 
de uma obra minha que eu tinha pintado.

CAROLINA: Você está falando do painel?

ENIVO: É. Tem uns filmes também para te mostrar, um vídeo, bem bonito. Com ele, o Mmoneis, a construção desse painel, com as cenas da represa. É bem bacana e tá bem fácil de te mostrar, porque acabei de mostrar pra um amigo esses dias. Então, é essa a ligação que eu tenho, sabe, essa coisa com a natureza. E aí construíram um lugar lindo. Hoje é um lugar limpo, um lugar lindo, um lugar maravilhoso, que eu tenho orgulho de levar as pessoas, estrangeiros, artistas, principalmente ali para o parque linear.

CAROLINA: Quer dizer, o parque é uma referência para sua memória da natureza, mas nesse caso é uma natureza construída?

ENIVO: Não, não tinha parque, antes era floresta. Nem casa tinha.

CAROLINA: Mas você falou que leva as pessoas lá.

ENIVO: Eu levo. E também porque tem o Ferruge, que é um cara muito interessante...

CAROLINA: O Ferruge tem me ajudado muito. É um grande parceiro

ENIVO: Todo mundo ali eu conheço desde criança, então é uma coisa linda. No dia que a gente foi andar de skate, é coisa de emocionar mesmo, de juntar todos os amigos e relembrar... Aquela nostalgia. Então, é um local onde eu me sinto em casa, por isso, que eu propago o Grajaú. Aquela região, aquelas águas. Lembro que tanto no skate, quanto na época que eu andava de patins, a gente descia ali a ladeira, e fazia isso dez vezes, porque descia, esperava a balsa, quando saia os carros a gente pegava a rabeira e subia tudo de novo. E ficava descendo e subindo, então, tem muita memória assim...

CAROLINA: Calma, pegava rabeira da balsa?

ENIVO: Não, da balsa não, dos carros. A gente ficava descendo e subindo, descendo e subindo, e sempre pegando esse fluxo. E tinha muito bombeiro passando também; morria gente demais, todo final de semana tinha morte. Ainda deve ter; não sei porque eu não frequento mais.

CAROLINA: É horrivel mesmo. No fim de semana passado, soube da morte de um garoto lá.

ENIVO: Tem, tem. Mas isso é direto. Morre muito. Já perdi amiguinho, o próprio Niggaz era muito jovem, tinha 20 anos. Toda semana, era muito bombeiro descendo, porque muita gente...

CAROLINA: E muitas pessoas entram na água depois de beber

ENIVO: É, exatamente. Aí, um começa a se afogar, um puxa, o outro puxa... E quando viu, dá uma desgraça, morreu uma família. Mas de manhãzinha, nossa, é perfeito. Quando eu fiz o mural, eu chegava todo dia às seis da manhã lá. Era algo muito sublime, aí tem yoga, tem umas aulas ali, o pessoal da ginástica ali no parque.

CAROLINA: Os mais idosos vão para o parque a essa hora.

ENIVO: Aí tem cavalo, vaca... 
CAROLINA: É uma fronteira entre o urbano e o rural.

ENIVO: É, o pessoal leva os animais para pastar um pouquinho lá... Então, é isso.

CAROLINA: O que eu não entendo é por que não tem salva-vidas?

ENIVO: Não tem. Tem segurança, mas não tem salva-vidas. E esse segurança não deve nem saber nadar.

CAROLINA: As pessoas pediram para colocar a guarita do segurança em frente ao pier, mas uma pessoa que não é especialidade em salvamento, pode se colocar em risco também.

ENIVO: Exatamente. Eu tenho uma foto ali do pier, que é tipo dois molequinhos em uma boia, acho que eles estão na mesma boia; ou é um em cada boia? Não tenho certeza... Mas o moleque está olhando direto pra câmera, devia ter uns 7, 8 anos, com um cigarro. Fumando um cigarro na boia, nossa... E ele já não cabia na boia, já era grandinho pra a boia. Muito louca a cena. Tipo fumando na maior elegância; ele e o amiguinho. Acho que eles estavam na mesma boia, fumavam e passavam o cigarro.

CAROLINA: Acho que você praticamente deu respostas a todas as minhas questões iniciais. Ah, você já viu alguém fazendo coisas estranhas na represa?

ENIVO: Jogar carro, o pessoal jogava.

CAROLINA: Nossa! Sobre o painel, eu entendi que foi uma iniciativa de fora para dentro, é isso?

ENIVO: É, total. mas o legal é que eles inseriram os artistas de dentro. Isso foi bom, porque podia perigar de vir só artistas de fora.

CAROLINA: Eu entrevistei o Boldarini, o arquiteto do projeto. Ele me disse que a comunicação com os grafiteiros não foi boa na época em que o parque foi contruído. O Tim tentou fazer um projeto com artistas vinculados ao Imargem, e acabou não dando certo. Acho que faltou talvez um pouco de vontade... Eles chamaram uma pessoa de fora que pintou todas as empenas das casas.

ENIVO: Que aí virou agenda, virou tudo isso. Vi aquele muro, negociei, o Tim me ajudou, falamos com os pichadores que eu ia fazer um painel, tinha outra coisa lá, apagamos e fizemos. Eu me dediquei mesmo, né, porque se eu quisesse pintar só uma muretinha eu pintava, eu pegava a grana e tudo bem. Mas eu queria realmente dar um presente significativo para o meu bairro.

CAROLINA: Tanto que continua lá. A pintura original não existe mais faz tempo.

ENIVO: Então, mal sabiam eles a potência que tinha ali de artistas do Grajaú. Ou indiretamente fizeram a boa, pintaram ali só com cores, e o pessoal meteu a arte deles.

CAROLINA: É, você pode enxergar dessa maneira também: "Ah, unificaram toda a superfície para...

ENIVO: As pessoas fizeram a parte delas, né? Mandaram brasa.

CAROLINA: As ruas funcionam como sobreposição? Não há uma estética única. Olha, desconhecimento meu mesmo, mas há meninas no movimento de grafite? 
ENIVO: A Carol Pires é quem administrou, está envolvida, administrou por muito tempo o Imargem. Tem a Mariana Belmonte. São as meninas que são articuladoras, são produtoras, pessoas que organizaram bem formalmente isso daí.

\section{CAROLINA: Elas são do Grajaú também?}

ENIVO: São do Grajaú. Acho que a Mari é de Parelheiros, e a Carol é do Grajaú. Tem a Sop, que trabalha no Pimp My Carroça, do Mundano. Então, várias articulações sociais; elas estão envolvidas com as cooperativas de lixo lá. Fazem pelo Brasil inteiro, na verdade pelo mundo, com isso de cooperativa de reciclagem. São mais articuladoras. Mas como artistas, atuam mais nas pinturas locais. A Índia tem as meninas que tem uma ação local lá, mas não ligadas diretamente às ações da represa. Estou tentando pensar aqui, talvez apareça.

CAROLINA: As mulheres aparecem menos, elas estão mais na organização, é isso?

ENIVO: Fazem a coisa acontecer.

CAROLINA: No dia da inauguração da pista, eu vi uma menina skatista. Uma.

ENIVO: Verdade, só tinha uma.

CAROLINA: Tudo bem, vinte anos atrás não teria nenhuma.

ENIVO: Eu lembro que ela andava bem. Tinha mó estilo. Mas no grafite geral tem muitas, muitas de nivel altíssimo. Só que envolvidas nessas açōes mais especificamente, não me recordo. Principalmente, no Grajaú.

CAROLINA: Você tem fotos da época em que você passeava com seu tio pela represa?

ENIVO: Não. Se perderam com o tempo. Não tiveram respeito com a história da minha família e jogaram fora.

\section{CAROLINA: É mesmo?}

ENIVO: Morou um pessoal estranho com meu tio. Depois, ele morreu. Alguns vizinhos falaram que viram algumas fotos no lixo, um pedaço de foto nossa. Perdemos umas coisas especiais. De antigo não tem nada. Talvez tenha algumas fotos do Imargem aqui.

CAROLINA: Quero ver, sim.

ENIVO: Também tem os vídeos. E eles são muito bonitos.

CAROLINA: Me interessa muito.

ENIVO: Então eu vou te mostrar, porque é uma sequência de vídeos do Imargem, na verdade, são divididos em cinco. Bem legal.

CAROLINA: Na pesquisa, os caminhos vão se cruzando, e acho que conheci o Imargem um pouco tarde. O Tim, claramente...

ENIVO: É a pessoa mais indicada para tudo. Ele é o articulador, para mim, mais cabuloso do Grajaú, da Zona Sul, porque ele é um mediador, um cara que realmente tá pelos movimentos. Anda a cidade de bike. Ele vem aqui de bicicleta direto. 
CAROLINA: Sério? De lá até aqui?

ENIVO: Ele anda muito de bike. Anda muito. Mestre.

CAROLINA: É bem longe...

ENIVO: É, são 30 km. E é arriscado.

CAROLINA: Sempre que vou para lá, penso que se pudesse ir pelo rio, pela represa, chegaria em dez minutos. Mas como vou de trem ou de carro, demoro duas horas. A água conecta tudo, mas a cidade separa. São as contradições geradas pelo modo como aproveitamos os recursos hídricos de São Paulo. Na verdade, como não aproveitamos.

ENIVO: Exatamente. O Tim te falou da Casa Ecoativa?

CAROLINA: Falou. Foi onde nos encontramos pela primeira vez

ENIVO: É um lugar que tem uma movimentação legal. Tem o sarau de cordas...

CAROLINA: É um lugar incrível mesmo. Eu vou precisar ir embora. Se você puder me mandar depois os vídeos e o material que você usa para divulgação...

ENIVO: Ah, tá. Vou mandar agora, senão eu esqueço.

CAROLINA: E, um dia, quero conhecer a galeria. Quando você volta de viagem?

ENIVO: Eu volto dia... Eu fico uma semana.

CAROLINA: Eu acabei esquecendo uma pergunta que queria fazer: a ponte de que você falou, cons- truída entre o centro e a periferia, você atribui a uma pessoa ou a um conjunto de pessoas?

ENIVO: Que ponte?

CAROLINA: O Tim me falou que o Niggaz fez esse movimento, sair da periferia e...

ENIVO: Ele fazia isso, exatamente. Ele que incentivou a gente a ir pra Vila Madalena. Ele e o Jerry. Eles que tinham isso aí. lam na minha casa, chamavam pra ir, tinha que pintar lá, que era onde a coisa ia pegar. Ele que foi nosso incentivador. Você tem o livro dele?

CAROLINA: Não.

ENIVO: Vou ver se acho um para te dar.

CAROLINA: Então, é isso. Se surgir mais alguma questão...

ENIVO: Pode me ligar, pode me encontrar na Sétima.

CAROLINA: Eu quero muito conhecer a galeria. Mas agora não dá

ENIVO: Você tá na correria agora, escrevendo?

CAROLINA: É, então, agora tenho isso para fazer.

ENIVO: Aí você vai pegar só algumas partes da entrevista?

CAROLINA: Minha ideia é apresentar a represa do ponto de vista dos narradores, quer dizer, mostrar como a paisagem da represa está presente na vida das pessoas. Mas não dá para romantizar, claro. Sabemos que são muitos os problemas gerados 
pelo modo agressivo que a cidade tem de crescer.

ENIVO: A represa mudou muito.

CAROLINA: Outro dia, olhando a paisagem toda ocupada ali, pensei: como resolver o problema de saneamento para toda essa gente. O Estado não está presente. Primeiro chegam as pessoas, e só depois o Estado aparece.

ENIVO: Tanto que eu nem sabia que tinha o parque, eu não sabia o que tinha virado aquilo. Aí, no comecinho de 2015, eu tava procurando um murão com um visual legal, e alguém me disse: "Mano, tem um lugar daora, você tem que conhecer". Fui lá e na hora já me apaixonei. Já falei: "É aqui".

CAROLINA: Você não acompanhou o processo.

ENIVO: Exatamente, foi tipo isso. Fazia muitos anos que eu não descia lá. É um lugar lindo, o pôr do sol... Foi super significativo.

CAROLINA: Esse lugar é muito especial.

ENIVO: É onde o sol nasce.

Ivar José de Sousa, 63 anos, morador e Subprefeito do Riacho Grande

IVAR: Meu nome Ivar José de Souza, eu tenho 61 anos de idade, sendo 59 só aqui no Riacho, eu sou mineiro de Três Corações, chegamos aqui na Vila Balneária que pertence também aqui à região do Riacho, eu tinha dois anos de idade.

CAROLINA: Você é uma ótima pessoa para falar do
Riacho Grande, então.

IVAR: Eu conheço um pouquinho.

CAROLINA: Que bom! Você tem alguma graduação?

IVAR: Sou advogado. Tenho um escritório de advocacia aqui no centro do Riacho há 16 anos. No ano passado, o prefeito me convidou, e eu fui dar uma assessoria lá na Fundação Criança, uma entidade ligada à prefeitura; fiquei um ano e três meses. Há noventa dias, fui nomeado subprefeito. O Riacho Grande é praticamente uma cidade dentro de São Bernardo. Nós temos aqui nosso centro comercial, banco, cartório de registro civil, todos os serviços públicos, temos UPA, UPS, três agências bancárias, vários restaurantes. Então, nós temos uma vida aqui no Riacho mais estruturada que muitas cidades do interior de São Paulo, que, vamos dizer assim, não têm a população nem a dinâmica que temos aqui.

CAROLINA: Qual é a população e do Riacho?

IVAR: Aqui no distrito gira em torno de 60 mil pessoas, quando eu falo de distrito, eu falo da represa para cá, porque aqui a subprefeitura atende também aquela região do outro lado da represa que são os bairros: Areião, Sabesp, Vila Estudante, Jardim Jussara, Vila Balneária, Lulaldo, Jurubeba; são bairros que administrativamente a gente atende, mas o distrito é da represa para cá.

CAROLINA: E a figura de subprefeitura existe faz tempo?

IVAR: A subprefeitura já existe há muito tempo, porque o Riacho é um distrito há 48 anos, me parece. O cargo de subprefeito existe desde a criação do 
distrito.

CAROLINA: Quando é o aniversário do Riacho?

IVAR: Tem até uma controvérsia na data. Ontem me falaram que é 24 de dezembro; na minha cabeça, era 12. Até vou checar porque um fala uma coisa e outro fala outra. Como é distrito, não tem aquela data comemorativa como tem a cidade. :Então, acaba esquecendo e caindo na dúvida quanto a data que foi criado o decreto da constituição do distrito.

CAROLINA: Há algum evento festivo ou religioso?

IVAR: Temos, por exemplo, em fevereiro, normalmente no primeiro domingo, a procissão de Nossa Senhora dos Navegantes. Essa procissão é histórica. Aqui no Riacho, antes mesmo de formar a represa, nós tínhamos muita extração de madeira para fazer carvão. Inclusive nessa aldeia indígena que eu fui hoje, eles tinham produção de carvão. Com advento da represa saiu muita madeira do próprio local que foi alagado

CAROLINA: É, vamos dizer que não se alaga uma área em que existe madeira. Tira-se a madeira antes; ninguém é bobo.

IVAR: Exatamente, então, toda essa madeira ela foi cortada e usada para carvão, tanto para indústria quanto para locomotiva. E tínham os batelões na época; cheguei a ver alguns. Os batelões eram barcos enormes que transportavam lenha. Antes, pegavam aqui pelas margens, e depois essas lenhas foram ficando mais distantes, e eles iam com os barcos, quilômetros, de passar dias e noites remando, para buscar a lenha.
CAROLINA: Isso antes da represa? Claro que a represa deve ter facilitado esse transporte.

IVAR: Antes da represa, eles tiravam lenha das matas, com advento da represa, eles tiravam lenha das árvores que estavam dentro da água. E na hora que acabou foram expandindo. Nós temos aqui um ou dois moradores, bem na faixa dos 90 e poucos anos, que trabalharam nessa atividade.

CAROLINA: Interessante. Quem sabe eu consigo entrevistá-los... Quais são os principais desafios da região?

IVAR: O principal que eu vejo como morador, e me tornei também um defensor dessa represa desde 1984, é essa divisão que fizeram. A represa foi compartimentada para que o esgoto do Pinheiros não avançasse. Então, o maior desafio é manter essa represa em condições de água potável. Hoje, nós temos só uma parte dela, a outra parte está totalmente comprometida. Então, um desafio é não deixar desmatar, não deixar poluir mais do que já está poluído, não deixar crescer os loteamentos clandestinos e as invasões, inclusive é um desafio que a administração está enfrentando e está colocando ordem na casa.

CAROLINA: Como urbanista, não tanto como pesquisadora em paisagem, mas como urbanista, eu acredito que a partir de um momento o melhor a fazer é organizar a ocupação e implantar um projeto de urbanização com saneamento. Você acha que com a compartimentação, que você mencionou, há um tratamento diferente de um lado e do outro da represa?

IVAR: Com certeza, aliás, a Sabesp deve muito para 
a gente aqui. Acho que ela não está trabalhando a contento nem dando importância à região e ao manancial, que abastece boa parte do ABC e parte de São Paulo. Então, o que a Sabesp fez, o que governo do estado fez naquela época, foi minimizar a carga poluidora no lado que eles fazem a captação, que a gente aqui olhando é o braço direito do Rio Grande. A Sabesp pensou: "Vamos dividir daqui para lá, vamos ter duas empresas, uma polui, a outra capta, trata e vende". Então, ao meu ver, a Sabesp devia ter um olhar diferenciado para cá, ser mais cuidadosa. Ainda têm muito esgoto a céu aberto correndo na represa, tanto desse lado que ela não faz a captação como do outro, apesar de que desse lado aqui nós mandamos água lá para o Guarapiranga, no braço Taquacetuba.

CAROLINA: Sim, há captação, e é bastante importante.

IVAR: Então, ao meu ver, ela não está olhando isso como se deve olhar, isso aqui é uma mina de ouro. Acho que esse ponto é falho, é bastante falha a questão do tratamento de esgoto.

CAROLINA: Então, a pergunta que eu faço é:, quem usa e quem abusa da represa?

IVAR: A represa é multiuso. A história da represa como turismo, como lazer, começou na década de 1960, que eu acompanhei. A pesca, a profissional acho que começou antes, mas a pesca do lazer, pesca de varinha, começou na década de 1960, se firmou na décado de 1970 e creceu na de 1980, tanto que o comércio de produtos voltados à pescaria ferveu nessa época. Hoje, ele está bem fraquinho porque o peixe também sumiu. Então, o pessoal vinha de tudo quanto era lugar, porque tinha muito peixe. Você pescava peixes grandes, bagres, traíras; tilápia de um quilo; pegava no anzol, traíra de dois, dois quilos e pouco; carpas. Tinha uma oferta de peixes bastante grande, e era um atrativo. Teve um sujeito, que era pintor de quadros, que montou uma cantina na beira da represa para casais. Isso aí pegou muito. E aí começou a aumentar também a oferta desse tipo de bar para casais. Essa orla da Prainha começou a ficar conhecida em qualquer lugar do ABC como lugar para casais, e o pessoal começou a vir muito. Começou a vir o casal à noite, mas depois vinha com a família durante o dia, sábado, domingo, frequentar a beira, por isso começou a tornar-se uma praia. Por que Prainha? Porque dava para nadar, era raso. A represa em si é cheia de barrancos perigosos

CAROLINA: O outro lugar em que estou fazendo meu estudo é o Cantinho do Céu, no Grajaú. Lá, na da margem da represa, já tem 15 metros de profundidade.

IVAR: Então, Prainha é porque ela tem essa geografia, dá pra usar como se fosse uma praia. Lá nos anos 1980, começou a corrida de moto náutica, foi fortíssimo esse esporte. Tínhamos aí várias pessoas que investiram, e isso começou a atrair gente. As pessoas começaram a conhecer, e nós não tínhamos estrutura nenhuma para receber turistas.

CAROLINA: Os turistas chegaram antes da infraestrutura?

IVAR: Sim, com certeza. Aí, no comecinho dos anos 1980, chegou o primeiro barco-restaurante flutuante.

CAROLINA: Eu almocei hoje no Nautilus.

IVAR: O Nautilus é o primeiro. Então, nós tivemos 
essa vinda desse barco. Hoje, nós temos três aqui e um outro na Estrada Velha. Isso começou a atrair mais gente. Aí, começou o comércio ambulante na orla da Prainha. O pessoal montava aquelas barracas precárias, sem higiene, sem nada. Em 2003, 2004, o pessoal começou a organizar melhor e vieram os trailers, padronizaram, ficou um pouquinho melhor.

CAROLINA: A represa chega até onde quando enche muito? Onde ficavam os trailers?

IVAR: Então, a água chega a encostar quase ali na mureta, quase no deque. Nós temos aqui uma marca chamada cota 747

CAROLINA: Sim, a cota maxima de alagamento.

IVAR: ISso, ela é muito próxima aqui da muretinha. Hoje, eu acredito que ela não chega mais na cota porque muitas áreas foram assoreadas, por isso perdeu espaço e essa água não chega mais na cota. Então, o pessoal chega a perder todo o espaço de prainha, de encostar no muro. Com alguns recursos do Governo Federal, o pessoal apresentou projeto de revitalização da Prainha.

CAROLINA: Eu estou muito interessada nesse projeto. Ele foi apresentado em 2014, certo?

IVAR: É, começou o estudo em 2010. 2011 aí foi. Em 2014, conseguiram emplacar, quer dizer, foi até um pouco antes.

CAROLINA: Mas foi uma demanda do município para o Governo Federal? Ou foi o contrário?

IVAR: Não, eles se organizaram, foi a administração anterior. Eles tinham uma facilidade no Ministério do
Turismo, que tinha recursos para a área de turismo. Eles emplacaram esse projeto e conseguiram fazer essa reforma. Mas o negócio é complicado, porque envolve a Cetesb, a Emae, que é detentora da área. A prefeitura entrou com um comodato para fazer algumas coisas, e aí conseguiram com o Ministério Público, e fizeram essa obra. Você vê que ela é feita de madeira, a parte do deque, tem toda a parte de permeabilização para a água poder infiltrar, o mais adequado possível.

CAROLINA: Você lembra qual foi a empresa que fez o projeto?

IVAR: Eu acredito que foi a própria prefeitura que apresentou o projeto, mas se teve alguma empresa contratada...

CAROLINA: Eu acho um arquiteto que desenhou o projeto. Essa é minha impressão, parece que houve um projeto de arquitetura.

IVAR: Tem, porque eu cheguei a participar de umas duas reuniões; eles convocaram os moradores para explicar o projeto. Na época, cheguei a questionar a questão da madeira, porque aqui tem muita neblina é um lugar muito úmido, falei: "Essa madeira não vai durar o que precisa". Foi uma arquiteta que fez a apresentação. Ela não se apresentou dizendo de qual empresa era, a prefeitura veio, apresentou o projeto, e como a gente não era da administração, eu não tenho esse conhecimento.

CAROLINA: A madeira provavelmente vai ter que ser substituída, mas isso faz parte.

IVAR: Já chegou o momento. 
CAROLINA: É, é isso, ela fica ao tempo, tem que substituir. A não ser que se use madeira de ipê, que dura para sempre e nem existe mais.

IVAR: Exatamente

CAROLINA: Eu queria muito saber quando se decidiu instalar uma estação de tratamento de esgoto ali atrás.

IVAR: Isso aí foi feito praticamente no começo da instalação do bairro, quando loteou. Minha primeira briga é tirar esssa estação daqui. Ela está obsoleta. Nós vamos trabalhar para tirar essa estação daí. Não tem cabimento. É, o primeiro lugar, considerado uma cidade, que o tratamento de esgoto fica no centro, não existe isso. E aquela alimentação que tem ali, aquela praça nem poderia estar ali. É totalmente inadequado aquilo.

\section{CAROLINA: Tem um emissário?}

IVAR: Não, eles dizem que tratam, e tem um cano que joga para a represa depois.

CAROLINA: Então. a água sai dessa estação de tratamento é jogada na represa?

IVAR: Isso. E o material sólido eles levam embora para incinerar em outro lugar.

CAROLINA: Eu queria saber quais são suas memórias da represa. Quando foi a primeira vez que você esteve aqui?

IVAR: Eu aprendi a nadar aqui. Vinha com meus irmãos mais velhos. Na época, a gente morava na Balneária. Comecei a aprender a nadar na represa com eles. la pescar também, e quando a represa secava, a gente fazia um campo de futebol na parte seca.

\section{CAROLINA: Que legal}

IVAR: A gente tinha uma relação assim: nadar, jogar bola e andar a cavalo na beira da represa.

CAROLINA: Outro dia eu vi uma turma andando a cavalo na Prainha.

IVAR: Tem, tem bastante.

CAROLINA: E onde você mora?

IVAR: Eu moro no centro.

CAROLINA: Quais são os eventos que acontecem na Prainha hoje?

IVAR: Na Prainha hoje, evento de grande porte não tem mais. Nós temos um evento, que é o show de verão, que a prefeitura promove; vêm artistas de nome nacional. Três finais de semana em janeiro, sábado e domingo. Estamos indo para a terceira edição. Tivemos a primeira edição em 2017, segunda edição em 2018 e vamos para a terceira edição, agora, em 2019. Esse é um evento grande, isso na Prainha. Fora isso tem algumas atividades mais isoladas. Tem um grupo de capoeira que faz apresentação, grupo de música que também faz apresentação O espaço não é muito grande para fazer atividade cultural.

CAROLINA: As pessoas vêm para cá de carro?

IVAR: A maioria vêm de carro, mas tem o transporte 
coletivo também

CAROLINA: Onde passa o transporte coletivo?

IVAR: Bem pertinho. O ponto de ônibus fica a duas quadras da represa.

CAROLINA: Como é feita a fiscalização dos restaurantes e do comércio?

IVAR: Nós temos regras para aqueles comerciantes que estão encostados na estação, são aqueles quiosques. Têm os números de mesa, por exemplo, cada comerciante pode ter seis mesas com quatro cadeiras, a mercadoria também é fiscalizada, e isso é feito pela prefeitura. E fiscaliza também os ambulantes, a gente não permite ambulantes lá naquela área, apesar de que, às vezes, não consegue segurar, e quando você vai lá ver... Como em qualquer lugar.

CAROLINA: O esgoto dos restaurantes flutuantes passa por onde?

IVAR: Eles despejam em caixas e é bombeado para a rede. Tem uma captação que é bombeada para a rede, que depois leva para a estação de tratamento. Isso é uma condição para eles funcionarem.

CAROLINA: E a segurança?

IVAR: O Riacho Grande é bastante seguro. Nosso índice de criminalidade aqui é muito pequeno. Nós temos reuniões toda última quarta-feira do mês, vem um delegado, um comandante da PM.

CAROLINA: Eu vi, vai ter uma reunião dia 28.

IVAR: Sim, tem uns pequenos frutos, a droga ainda é um mal que chegou aqui também, mas aqueles assaltos pesados não. As coisas aqui são muito tranquilas, porque nós temos a polícia rodoviária e nós temos a delegacia, tudo na saída. Ou o cara foge por aqui ou ele vai pelo meio do mato e entra na água. Então, antes de fazer qualquer delito aqui ele pensa duas vezes.

CAROLINA: Sim, é quase como uma ilha, não é?

IVAR: Isso. Lógico, onde tem gente, têm problemas. Domingo mesmo, tinha muita gente, muita mesmo. Tem algum probleminha, sim, com álcool; às vezes, exageram um pouco na bebida, mas nada que foge muito do controle.

CAROLINA: E como funciona a questão dos salva-vidas?

IVAR: Nós temos Corpo de Bombeiros, temos salva-vidas, que esse final de semana não vieram, e eu fiquei muito chateado. Mas a partir deste agora, eles já estão aí, porque eles vêm mais na época do verão. Eles fazem a operação-verão, era para terem começado domingo. Eles já estão treinados, estão sob a supervisão dos bombeiros.

CAROLINA: Eles são contratados por temporada, é isso?

IVAR: Sim, exatamente. São treinados e orientados pelos bombeiros.

CAROLINA: Mas não é permitido entrar na água, certo?

IVAR: A água não é própria para banho, mas é claro, as pessoas vão lá e pulam. 
CAROLINA: Essa poluição vem de outros bairros, certo? Teoricamente, o bombeamento do Pinheiros não é frequente.

IVAR: Para mim, é frequente, sim. Foi uma luta dos ecologistas para pedir o fim do bombeamento, mas aí alegam que a represa não foi feita para fornecer água, foi feita para fornecer energia. Mas a água da Billings não é suficiente para mover as turbinas, então bombeiam o Pinheiros. Então, a maior poluição vem do Pinheiros, porque o esgoto doméstico, por mais que seja, ele se depura sozinho. Mas o que vem de lá é muito pesado, são muitos metais pesados. Isso aí não tem como, ele vai sedimentando, vai virando um lodo. Essa parte aqui é bastante poluída por conta disso. E o esgoto que corre em alguns bairros aqui que não são canalizados também contribui, em carga menor, mas contribui.

CAROLINA: E como funciona com os barcos? Obviamente, só pode dirigir quem tem habilitação, mas você não acha que deveria ter uma proteção para os barcos saírem?

IVAR: Nós estamos agora mudando. Nós temos aqui algumas marinas, tem aquele pessoal que vive disso, alugam um espaço para estacionar lanchas, moto aquática. Algumas marinas tem uma rampa particular que tem que ter autorização, e nós temos uma rampa pública, que ali desce gato, sapato e boi. Eu vislumbrei uma rampa que hoje você não consegue fazer mais por causa de APP, porque você não consegue concretar mais a beira de represa. Ai, vislumbrei ter uma rampa do outro lado, também pública. Eu já mandei limpar, aí eu vou separar.

CAROLINA: Já está executada?
IVAR: Já está prontinha, só falta adequar, vou reformar. Aí, nós vamos adequar esse tipo de embarcação particular, não aquele que tem nas marinas. Aí, ele vai lá nessa outra rua, vai descer com outra lancha, outra moto aquática, eu vou separar um pouco. E nós vamos agora trabalhar para colocar boias.

\section{CAROLINA: Isso é interessante.}

IVAR: Para demarcar até onde essas motos podem chegar, porque elas são perigosas, e quem usa nem sempre tem o cuidado que tem que tomar. É a Marinha, que agora tem um convênio com a GCM, que fiscaliza. Então, agora os guardas são treinados para fazer fiscalização dentro da água, porque a represa é responsabilidade da Marinha em questão de navegação. Então, a documentação das embarcações, habilitação de quem está conduzindo é responsabilidade da Marinha. O cara entrou na água, ele pode ser fiscalizado, preso, multado, o que for. Essa questão dos barcos é isso.

CAROLINA: Acho que cabe a vocês pensar em como delimitar o uso, daqui para cá sim, daqui para lá não.

IVAR: ISso, eu já estou correndo atrás de quem vai patrocinar essas boias para poder demarcar, porque é muito perigoso. Nós tivemos um acidente domingo passado, tivemos a informação depois de que o rapaz veio a falecer, porque bateu dois jet-skis, um de frente com o outro. Eles abusam, bebem, e lá na represa não é igual aqui que se tem bafômetro. Então, eles abusam bastante, tem que tomar cuidado.

CAROLINA: Logo depois do feriado, foram registradas cinco mortes em represa: três na Guarapiranga 
e duas na Billings.

IVAR: Duas foram aqui

CAROLINA: Aqui no Riacho? Na Prainha?

IVAR: Na Prainha. Acho que virou a noite nessas casas noturnas bebendo, de manhã chegou aqui, foi nadar e morreu.

CAROLINA: Ivar, como é a relação com as pessoas, você já tinha uma convivência com a comunidade ou isso está muito mais forte agora?

IVAR: Eu sempre tive uma boa relação com a comunidade porque eu sempre participei de tudo. Trabalhei numa empresa aqui por trinta anos; entrei com 15 e com 17 anos eu já era gerente. Eu que admitia, que mandava embora

CAROLINA: Você já fazia relações públicas, recursos humanos, tudo...

IVAR: Sim, e sempre participei de tudo, sociedade, amigo, fórum dos moradores, conselho. Esse viaduto para sair foi uma briga. Eu sou briguento, esse viaduto nosso foi construído em 2006. Antes disso, só passava carroça ali, porque era muito baixinho.

CAROLINA: Você fala de qual viaduto?

IVAR: Esse que passa embaixo da Via Anchieta. A gente lutou muito, brigou muito. Aí, eu saí candidato a vereador. Então, nessa questão da política a gente vai conhecendo muita gente, e depois que eu fui para o escritório de advocacia muita gente me procurava para orientação, para fazer serviço. A minha relação com o Riacho é muito grande. Eu sou da primeira turma do ginásio do Riacho. Aqui não tinha ginásio, se quisesse fazer ginásio tinha que fazer em São Bernardo. Em 1970 abriu o ginásio, eu sou da primeira turma. A gente tem bastante história, porque tem muitos anos aqui dentro. Agora na questão política, o Riacho Grande é muito complicado, você faz dez coisas boas, aí alguém vê um montinho de entulho ali no cantinho. Hoje é muito fácil reclamar... Tem o Face, né?

CAROLINA: Você acaba se expondo muito, não é?

IVAR: É, mas eu vejo isso como saudável. Eu acho que a crítica, seja ela qual for, é porque as pessoas estão participando.

CAROLINA: É porque elas estão de olho, estão participando.

IVAR: Uns de maneira errada, outros de maneira certa. A gente vai tocando. Como a gente vê muita crítica, e eu sempre fui de ir atrás, eu tiro de letra.

CAROLINA: Eu estou muito interessada nessas duas pessoas de quem você falou, que que faziam o transporte de madeira. Elas são acessíveis?

IVAR: Sim. Aqui, também, eu vou fazer questão agora de fazer uma exposição. Nós vamos inaugurar a reforma da biblioteca.

CAROLINA: Essa biblioteca é incrível. Eu sabia que estava em reforma, que não estava aberto, mas eu entrei e dei uma olhada... É um espaço muito gostoso.

IVAR: O dono da empresa que eu trabalhei trinta 
anos, hoje ele está com 84 anos, é escultor, ele tem obras maravilhosas. Simplesmente, a prefeitura, em 2013, não deu muita importância e queria doar tudo. Aí, por uma coincidência do destino, a prefeita da cidade que ele nasceu, lá na Espanha, descobriu ele e ofereceu para ele um museu; e ele levou tudo para lá.

\section{CAROLINA: E ele era aqui do Riacho?}

IVAR: É, ai ele voltou a fazer algumas coisas. Acabou de terminar uma baiana de mármore, ficou linda. E ele tem uma câmara de São Bernardo, um João Ramalho e uma índia potira tamanho natural. Estou trazendo agora e vamos fazer uma exposição aqui na nossa biblioteca.

CAROLINA: Que vai inaugurar daqui a pouco, certo?

IVAR: Vai inaugurar sábado ou domingo que vem. Vão ficar quase um mês em exposição as peças dele. Só que ele falou para fazer fotos de todas as peças que estão no museu da Espanha.

CAROLINA: Então, pelo menos as fotos vêm, não vêm as peças mas as fotos estão aí.

IVAR: Exatamente.

CAROLINA: Legal, muito legal.

IVAR: A secretaria do Meio Ambiente fez simplesmente o favor de mandar cinco mil disso aqui [mostrando um kit ecológico].Aí eu falei: "Como que você me manda cinco mil, como é que me entrega isso?". Eles disseram:"Ah, entrega ai". Na mesma semana, eu fui procurado por um bombeiro que estava abrindo uma ONG aqui no Riacho, chamada Bombeiros Mirins, eles faziam atividades de primeiros-socorros, eles ensinam muita coisa. Faz muito tempo que ele faz a coisa no papel, e ele veio me pedir ajuda. Aí, eu em casa, pensei: "Vou usar essa ONG". Chamei eles e falei o seguinte: "Vamos fazer um trabalho em parceria?". Eles toparam. Eu falei assim: "Eu quero que vocês me ajudem a fazer uma árvore de Natal de garrafas pet, só que não é pequenininha não, é de 15 metros". O que eu fiz: ajeitei com todas as escolas da região, sala por sala, conversei com mais de 5 mil alunos. E entreguei o folheto para eles, expliquei sobre a importância do "lixo no lixo", falei dos ratos e pedi para eles trazerem garrafas pet. Nós já temos 3 mil. Hoje ainda vou correr atrás da estrutura, as tiras já estão montadas, as garrafas estão lavadas, e vamos colocar bem na entrada do Riacho, bem na orla da Prainha, toda iluminada. Vamos fazer a rua mais bonita e enfeitada da região, e vamos fazer a árvore. Eu acho que nós temos condições de fazer muita coisa boa, o poder público ajudando um pouquinho, porque, eu que vim da iniciativa privada, venci muito essa dificuldade, tudo é difícil começar, mas porque falta boa vontade dos agentes. Sai a campo, vai atrás...

Quirino Vincentin, conhecido como Leli, 93 anos, aposentado, morador do Riacho Grande

Solange Vincentin, 63 anos, filha de Leli, aposentada, moradora do Riacho Grande

LELI: Meu nome é Quirino Vicentin, sou casado com a Teresinha. Temos três filhos, cinco netos, seis bisnetos e tem um tataraneto também.

CAROLINA: Nossa, que beleza! 
LELI: Já estamos com 63 anos de casados, sempre morando nesta casa. Eu sou de 1925, tenho a idade da Billings. No mesmo ano que nasceu a Billings, eu também nasci, então, eu já estou com 93 anos e meio.

CAROLINA: O senhor faz aniversário quando?

LELI: Dia 20 de agosto. A patroa completou 87 no dia 24 de novembro.

CAROLINA: Nenhum dos dois aparenta a idade que têm.

LELI: Não parece, né? Então, eu fui pescar antes da represa, pescava no rio. Eu lembro que era mulecote e ia, com meus irmãos, pescar antes da represa chegar aqui, porque ela, devagarzinho, fechou as comportas em Santo Amaro, e até ela aparecer aqui demorou. Foi aparecer em 1932-1933 aqui no Riacho, e encheu até a cota 47. Eu, com o tempo, comecei a trabalhar nos barcos, durante uns 20 anos, puxei lenha para esses batelões.

CAROLINA: O senhor tem foto dessa época?

LELI: Tenho.

CAROLINA: Vocês são de família italiana originalmente? Têm ascendência italiana, certo?

LELI: Tenho ascendência italiana. Ia pescar no rio antes da represa, depois com o tempo meu primeiro trabalho foi puxando lenha aí nos batelões com meu cunhado, logo comprei barco... Antes de 1945, trabalhava no remo carregando esse barcão com 60 metros de lenha, em dois. Depois de 1945, comprei uma lanchinha e trabalhei até 1962 na represa. Daí, comprei um caminhão e fiquei trabalhando com ele até completar os 84 anos. Agora não estou fazendo nada.

CAROLINA: O senhor trabalhava com transporte de lenha, não com extração certo?

\section{LELI: Só com o transporte.}

CAROLINA: E quando sua família original veio para cá?

LELI: A minha mãe tinha um boteco, dava uma pensãozinha para as pessoas, mas tinha bem pouca gente.

CAROLINA: Quando a família veio da Itália já veio para o Riacho Grande?

LELI: Meus avós vieram e ficaram numa colônia no Bairro dos Finco.

CAROLINA: Já tinha o pessoal que trabalhava com madeira, marcenaria, ou isso foi um pouco depois?

LELI: Um pouco depois. Teve a serraria, que cortava madeira aqui do Bortolo Basso ali nos Finco; tinha uma outra que fabricava cadeira; e tinha um moinho que moía fubá.

CAROLINA: E como vocês faziam nesse começo, nessa época que o senhor carregava madeira? Onde vocês compravam alimentos? Tinha gente que produzia?

LELI: Tinha o armazém do Marino Bequelli, italiano também. Depois, chegou o Américo Pieroni, que fez outro armazém. Esse Marino acabou logo, e depois 
veio esse Américo Pieroni. E nesse batelão, quando trabalhava no remo, a gente dormia lá dentro dele, porque demorava três dias para fazer uma viagem. la lá carregava metade, depois no outro dia carregava a outra metade, à noite vinha embora, de dia ou à noite, e no outro dia descarregava.

CAROLINA: O percurso era de onde até onde?

LELI: Na balsa, rio acima, toda essa beirada aí, no Taquacetuba.

CAROLINA: Que é mais do lado de São Paulo; e descarregava onde?

\section{LELI: Descarregava tudo na Prainha.}

SOLANGE [filha do senhor Leli, que participou da conversa]: E a lenha era utilizada em padarias e olarias.

LELI: Na época, tinha a fábrica da Kovarick, em Santo André, fábrica de vidro. A Kovarick usava muita lenha.

CAROLINA: A lenha era usada para cozinhar também...

LELI: Sim, fogão a lenha, tudo à lenha, tinha muita olaria.

CAROLINA: Uma outra pessoa me disse, mas ela conhece mais o lado de Itaquaquecetuba, e o senhor pode confirmar ou não, que muita árvore já tinha sido extraída dessa região, não era mais uma região tão densa, mas a mata foi se regenerando aos poucos.

LELI: Foi se regenerando, agora nem dentro do quintal você pode cortar mais.

CAROLINA: E de onde começaram a cortar? E foi para que lado?

LELI: Eles encostavam a lenha na beira da represa para pegarmos; às vezes, era com carretão, às vezes, era com tropa...

CAROLINA: Tropa?

LELI: Tropa é um cavalo com dois ganchos. Eles enchiam de lenha e vinham. Era madeira ou lenha, vamos assim dizer; às vezes, era carvão. No começo, vinha tora para a serraria.

CAROLINA: Eles separavam a madeira de maior qualidade e a madeira...

LELI: As maiores vinham para fazer tábuas.

CAROLINA: E quem fazia a extração?

LELI: Tinha muita gente que morava nesses matos, e eles cortavam, com a machadinha, eles cortavam a lenha. Tratava de três, quatro filhos; era uma vida difícil, mas não tinha outra coisa.

CAROLINA: Imagino, e não tinha energia, gás...

LELI: Quando nós viemos morar aqui, não tinha energia. Foi em 1957 que chegou a energia aqui. [Leli aponta para filho e fala]: Ele tinha três dias quando a energia chegou,

CAROLINA: E quem construiu a casa de vocês?

LELI: Essa casa foi o Emilio Medeiro, e eu que paguei 
para fazer. Era o Emilio Medeiro que era o responsável, mas quem construiu mesmo aqui foi o Albino Zampieri, que ainda está vivo, tem uns 91 anos; e o Dário Tozi, que já faleceu.

CAROLINA: O senhor trabalhou intensamente até os 84 anos. Primeiro, fazia o transporte nos barcos; depois, começou a fazer transporte de caminhão. Tem alguma coisa de que sinta falta dessa época?

LELI: Com o caminhão, foi transporte de tijolo, pedra e areia.

SOLANGE: Pai, eu sinto falta de pegar água para fazer café.

LELI: É, nós tomávamos água da represa mesmo, fazia café, comida; era água limpa aquele tempo.

CAROLINA: Vocês não tinham poço aqui na casa? Usavam a água da represa?

LELI: Aqui tem poço.

SOLANGE: Quando ele trabalhava no batelão, quando ele trabalhava no barco, ele pegava água na represa pra fazer café, comida.

CAROLINA: Até quando deu para fazer isso?

LELI: Até 1952, mais ou menos.

Teresinha [esposa do Lelis]: Foi antes de nós casarmos, porque nós casamos em 1955.

LELI: Aí a água começou a ficar verde, verde, começou a jogar do Tietê para cá, ai ficou ruim a água.
CAROLINA: E depois, mais para frente, quando teve um problema maior mesmo, foi na década de 1970. Apareceram muitos peixes mortos. Vocês se lembram disso?

LELI: Lembro, acompanhei tudo.

SOLANGE: Era a seca.

LELI: Foi o ano que eu comprei o caminhão, porque a água já estava meio baixa.

SOLANGE: Não foi em 1962 que a represa baixou, ficou no zero?

LELI: É, ficou bem na beirada do morro, bem baixo. CAROLINA: Onde é a beirada do morro?

LELI: Do outro lado da represa, Vila Balneária. Onde o rio passa embaixo da ponte.

CAROLINA: O rio, originalmente, passava muito mais para o lado de lá da Anchieta, certo?

LELI: É, na beira do morro.

CAROLINA: Se a gente prestar atencão, o morro ali é bem mais alto, e aqui é bem mais baixo, então, provavelmente...

LELI: É, aqui foi lançante assim, lançante até chegar para lá.

CAROLINA: Aqui já era mais plano, então?

LELI: Era. 
SOLANGE: E o rio vem lá de cima, né, pai?

LELI: Lá no Rio Grande, na serra.

CAROLINA: Ele nasce em Paranapiacaba.

SOLANGE: Não é esse não, pai.

CAROLINA: Existem dois, o Rio Grande, que nasce em Paranapiacaba; e o Rio Pequeno, que nasce um pouco mais para baixo.

SOLANGE: Isso, esse Rio Pequeno que deságua aqui do lado do Estoril e vem para cá.

CAROLINA: Isso. São dois braços da represa.

LELI: O Paranapiacaba e O Tietê, que nasce lá em Salezópolis.

SOLANGE: Já vai por São Paulo, já vai poluindo lá por São Paulo.

CAROLINA: São Paulo é uma tristeza, porque não trata esgoto; e, além de não tratar esgoto, suja a água da Billings. A água que vocês usam ainda é do poço?

LELI: Aqui da cozinha é, para tomar banho, lavar roupa é tudo da rua.

CAROLINA: Vocês usam as duas águas, da Sabesp e do poço.

LELI: É. Antigamente, a prefeitura estava até fechando poços.

CAROLINA: Por algum motivo?
LELI: Não sei por que motivo. Eles queriam que fechasse, o meu aqui nunca chegou essa época.

CAROLINA: O terreno aqui é maior, não é? Tem uma parte que...

LELI: Aqui, que vinha lá de cima, era do tio dela [da esposa]. Tudo daqui até o ginásio lá em cima era do tio dela. Um primo meu ia casar também, filho do tio dela; então, eles fizeram o poço aqui e iam fazer a casa. Dai, a prefeitura falou: "Vocês não podem construir, pois essa rua está projetada para abrir esse pedaço aqui". Só tinha essa rua Marcílio Conrado rio acima. Aí, o tio dela falou: "Faz mais pra cima, tem muito terreno lá pra cima". Aí, fez pra lá; só depois de 24 anos que abriram a rua.

CAROLINA: Nossa, demorou!

LELI: Ficou esse bico aqui. Aí, comprei um terreno, onde mora meu filho hoje, e fui fazer um poço lá; deu 6 metros de terra, depois deu mais 6 metros de caulinho, branquinho de cima em baixo. Meu sogro trabalhava com caulinho e não deixou a gente construir lá: "Vamo arrumar outro terreno, eu vou ficar com esse terreno aí e vou comprar outro para você". Aí, o tio dela falou: "Tem um bico ali que acho que dá para você construir". Comprei aqui, vendi lá para meu sogro; depois, na divisão da herança do sogro, caiu para ela outra vez o mesmo terreno.

CAROLINA: Era destino.

LELI: O cunhado dela [da esposa] queria comprar de todo jeito, mas ela falou: "Não. Eu vou deixar esse terreno para o meu filho". Ele pagava aluguel em São Bernardo. Fiz a casa: ela deu o terreno, eu dei a 
casa. Vieram morar aqui também, ficou tudo perto.

LELI: Qualquer coisa se parla. Essa aqui já foi na Itália.

CAROLINA: Toda a família, até os bisnetos?

SOLANGE: Eu fui fazer um curso, cheguei a fazer

SOLANGE: Esse meu irmão mora aqui encostado, uns dois anos e pouco. Era um intercambio numa no sobrado que também foi meu pai que construiu, e hoje ele que mora...

CAROLINA: E a senhora? escola lá.

CAROLINA: Perto da região de onde eles tinham vindo?

SOLANGE: Eu moro no centro, um pouquinho mais para frente.

SOLANGE: É, a gente já foi lá conhecer.

LELI: Onde nosso bisavô, talvez tataravô...

CAROLINA: Finco, é um sobrenome italiano, certo?

SOLANGE: É de uma família italiana.

SOLANGE: A gente tem um primo lá, que foi descoberto pela internet.

LELI: Dos meus tios, tinha tio que morava lá.

CAROLINA: Que legal.

CAROLINA: A origem da família de vocês é de qual região da Itália?

SOLANGE: Aí, a gente está mantendo um pouco de contato.

LELI: Até ele veio passear aqui.

SOLANGE: Veneto.

CAROLINA: Vocês têm fotos de época da represa?

CAROLINA: E os outros italianos também eram dessa região ou se encontraram aqui por acaso? Ou se conheciam na Itália?

LELI: Tenho, eu vou mostrar.

SOLANGE: Acho que eles se encontraram aqui, né, pai? Não sei te falar de que região eles são.

CAROLINA: Aí, vocês me contam um pouco da história pelas fotos.

LELI: Acho que sim, não sei explicar.

LELI: Isso aqui é quando nós completamos 60 anos de casados; ela [a Solange] me levou para um passeio de navio.

CAROLINA: O senhor ainda fala italiano?

LELI: Falo, qualquer coisa se fala.

SOLANGE: Porque como ele sempre trabalhou de barco, ele não conhecia o que é um navio hoje, essa

SOLANGE: Se parla. 
CAROLINA: É um país inteiro.

SOLANGE: Este aqui da foto já era um barcão pra ele. Se você olha de longe é quase o mesmo tamanho, só que ao invés de ter luzes, tem um monte de bandeirinha.

SOLANGE: Aí, a gente levou; eles estavam fazendo 60 anos...

CAROLINA: Sessenta anos de casados em 2015.

SOLANGE: Eles até foram homenageados; a gente falou que eles estavam fazendo 60 anos de casamento, e eles ganharam um champanhe.

CAROLINA: E vocês gostam de tomar um vinhozinho?

TERESINHA: Eu adoro; meu pai fazia aqui.

CAROLINA: Eu ia perguntar isso, porque a origem italiana... E como foi a história da construção da biblioteca? A biblioteca foi uma demanda de vocês daqui do Riacho? Vocês que pediram por uma biblioteca?

SOLANGE: Eu trabalhei na Biblioteca Machado de Assis, 25 anos, eu sou bibliotecária de formação. Eu, assim, na época não acompanhei muito. Eu não morava aqui, eu estava morando no centro de São Bernardo

CAROLINA: O vereador estava criando problema, não estava?
SOLANGE: A gente sempre teve que depender muito de São Bernardo, né? Aqui só tinha até a $4^{\text {a }}$ série. Depois do curso de admissão, a gente já tinha que se deslocar para São Bernardo, e não tinha como.

CAROLINA: Aos poucos foi chegando... Esse livro aqui...?

SOLANGE: Esse aqui é um livro que o Toninho Macedo escreveu.

CAROLINA: O Toninho Macedo é uma pessoa aqui do Riacho?

SOLANGE: Não, é de São Bernardo, professor e pesquisador, mas isso já faz...

LELI: Em 1991.

CAROLINA: Esse aqui é um jornal do Grande ABC? 24 de fevreiro de1991.

LELI: Sim.

CAROLINA: "O saudoso historiador de São Bernardo... Aldo e Nazareno participam do projeto histórias de Riacho Grande, iniciativa da divisão de bibliotecas, que já está reproduzindo o acervo de Quirino Vicentin, o Leli...". Quem deu esse apelido para o senhor?

LELI: Ah, desde moleque, não sei.

CAROLINA: Tem uma cantina em São Paulo, perto da minha casa, que se chama Cantina do Lelis... Tem Leli, tem Lelis e tem Lelo. Acho que é um apelido italiano, não sei... 
SOLANGE: No Lelis, a gente já levou eles. Estavam comemorando aniversário de casamento também.

CAROLINA: Que legal, foram lá para São Paulo. Essa pessoa, o Nilton Ataliba, juntou as histórias dos moradores de Riacho Grande, não foi? Isso chegou a virar um livro?

SOLANGE: Acho que não. Houve várias vezes projetos para levantar a história aqui do Riacho, mas você sabe, administração muda, tudo muda, tudo se acaba.

CAROLINA: A história é mais importante do que as pessoas que estão contando. Tinha que dar continuidade...

SOLANGE: Várias vezes, a gente acompanhou.

CAROLINA: Eu vou transcrever esta entrevista, e ela vai para o meu mestrado; então, de alguma maneira isso vai estar na biblioteca lá da Universidade de São Paulo. É alguma garantia de que a história não vai se perder, que estará lá documentada.

SOLANGE: Então, agora mesmo tem uma pessoa, filha de uma prima dele, que quer fazer, quer levar a história do Riacho, das famílias tradicionais.

CAROLINA: Ótimo.

SOLANGE: Ela deu até uma entrevista esses dias para o Ademir Médici, historiador de São Bernardo; e ela quer continuar, também é uma pessoa de uma família bem tradicional.

CAROLINA: Como ela se chama?
SOLANGE: Anselma Brentegani, ela está pensando em fazer isso aí.

CAROLINA: Seu Leli, conta sobre esta foto aqui.

LELI: Isso aqui é de 1950, fazendo a procissão.

CAROLINA: De Nossa Senhora dos Navegantes?

LELI: É, esta aqui é de 1952.

CAROLINA: Também da procissão, certo?

LELI: É. Esta aqui é de quando eu jogava futebol.

CAROLINA: Onde era esse campo?

SOLANGE: Era aqui no Riacho.

LELI: Esta aqui foto foi tirada em São Bernardo, quando era o campo do Palestra.

CAROLINA: O senhor é palmeirense?

LELI: Não, são-paulino.

CAROLINA: Eu também sou são-paulina; foi por isso que eu gostei do senhor.

SOLANGE: E tem também a história dos defuntos, né, pai?

LELI: Não, isso aí depois a gente...

CAROLINA: Pode contar...

SOLANGE: Depois ele vai lembrar. 
CAROLINA: Tudo bem.

LELI: Esta aqui é de 1991. Era dia de procissão também.

SOLANGE: Enfeitavam com bandeirola, taquara e bambu.

CAROLINA: A procissão foi retomada, não foi?

LELI: Foi, em fevereiro tem, mas só com lanchinhas pequenas, barco pequeno. Aqueles batelões... A gente colocava até cem pessoas dentro, vinha embora tranquilo. Se carregava 60 metros de lenha, 100 pessoas...

CAROLINA: Não fazia nem cócegas.

SOLANGE: Mais de uma vez no ano, né, pai? Eram três festas que eles comemoravam.

LELI: Eram três, começava em 20 de janeiro, dia de São Sebastião; a gente ia até o Bororé, levava a turma; tem uma igrejinha lá.

CAROLINA: Tem uma igrejinha lá, e tem uma vendinha ao lado.

SOLANGE: ISSO.

LELI: Antigamente, o nome lá era Maurílio, chamava Maurílio o antigo de lá. Depois, eu fui lá um tempo e perguntei se tinha algum filho do Maurílio, e um falou que era filho dele. Até agora, há pouco tempo, um sobrinho meu, o Bastião, levou a gente lá, eu entrei no barzinho e tinha um neto dele lá, chamava Edson, 3a geração.
CAROLINA: Parece que a casinha da vendinha é mais antiga que a igreja.

LELI: É antiga mesmo, viu; e aquela madeira está lá do mesmo jeito. A senhora conhece lá?

CAROLINA: Eu fui faz umas duas semanas conhecer a Casa Ecoativa. Era um espaço da Emae, o órgão que administra a represa; um grupo de pequenos produtores agrícolas fazia reuniões nesse espaço; então, a Emae acabou doando o lugar para eles. Eu fui um dia para conhecer o grupo, e tinha uma reunião da universidade acontecendo. $\mathrm{Ai}$, uma dessas pessoas me levou para conhecer a igrejinha e a vendinha, está lá igual, igual. Até me deram uma cachacinha de...

\section{LELI: Cambuci?}

CAROLINA: Isso, de cambuci.

LELI: Se quiser, tem aí também.

CAROLINA: Ah, depois eu vou aceitar, claro! Como não?

SOLANGE: Tem o pé de cambuci aqui em casa. Tem mais de 50 anos.

LELI: Tem 55 anos que eu plantei esse pé de cambuci.

CAROLINA:. Agora, uma pergunta que eu ia fazer: a represa foi enchendo devagar... O senhor consegue lembrar como foi? E quem tinha terra perto do rio, o que fez?

LELI: Meu pai mesmo tinha, eles indenizavam. Se 
quisesse vender, combinar tudo bem, se não a água ia enchendo...

CAROLINA: Não tinha muita escolha.

LELI: Vou falar uma história para a senhora: tinha um morador teimoso, João Mendes, tio da nossa mãe. Ele tinha uma casa que a água ia chegar, mas quase por último; e ele teimoso falando: "Eu, daqui eu não saio, quero ver se alguém vem tirar meus filhos daqui, quero ver"; nós falamos: "Ninguém vai tirar seus filhos daí, o senhor vai ter que sair". Aí, quem fez a mudança dele? Eu, com o batelão...

CAROLINA: A água estava na porta, então?

LELI: A água já estava batendo no assoalho, e a rua para chegar caminhão já tinha sido invadida pela água. Fui com o batelão, carregamos a mudança dele e trouxemos aqui no Largo Azul, porque esse terreno do Largo Azul era do João Mendes. Mas ele teimoso falando: "Daqui não saio, quero ver quem me tira". Eu falei pra ele: "Ninguém vai tirar seus filhos daí e jogar fora, uma hora ou outra, você vai ter que sair".

CAROLINA: E ele foi esperando até a água chegar... E esta foto, o que é?

SOLANGE: Esta foi recente.

CAROLINA: Faz muito frio aqui?

SOLANGE: Faz muito frio. Nossa, você nem imagina.

LELI: Esse aqui é irmão do meu pai, está com 95 anos. Esse é o Aldo Rosa, que faz o vinho aqui no Riacho até hoje. Família Rosa, família tradicional daqui também.

CAROLINA: O que é este diploma, seu Leli?

LELI: Quando construíram a matriz em São Bernardo, em 1945, eu ajudei; colaborei pagando uma mensalidade por um ano. No fim, eles me deram um diploma, a matriz de São Bernardo me deu.

SOLANGE: E este aqui do que é? Da igreja daqui?

LELI: Daqui da igreja também.

SOLANGE: Ele ajudou muito a igreja do Riacho.

LELI: Essa igreja aqui, a primeira reunião eu fui lá.

CAROLINA: Ela foi construída em 1970, não foi?

LELI: Em 1969; depois, em 1970, foi inaugurada. Essa primeira matriz, era o Álvaro Landi que era subprefeito.

\section{CAROLINA: Alvaro Landi?}

LELI: Isso, e tinha uma igreja de madeira, uma coisa feia danada. Ele entrou como subprefeito, mandou reunir cinco pessoas mais ou menos; fomos lá e ele falou: "Precisa fazer uma igreja aqui, porque vai vir uma companhia, a Dersa, fazer a via Anchieta, e fica feio essa igreja". Ai, logo o Jaime Pedroso falou que ia contribuir com 20 mil tijolos, "Pode pegar na olaria do Lito de Marque". Olhei pra lá, olhei pra cá, e só eu que tinha caminhão. "Quem é que vai puxar esses... o Leli puxa, o Leli carrega". Aí, a dona Branca, da Vila Balneária deu 10 mil, o Português também deu 10 mil. Quarenta mil tijolos, fui eu quem carregou. 
CAROLINA: Quer dizer, então, que essa igreja não saia do chão se não fossem os tijolos carregados pelo senhor.

LELI: É, e assim foi. Depois mais gente ajudou, uma coisa ou outra, fazia mutirão para fazer. Em 1970, mais ou menos, ela ficou pronta, nem pronta, só o piso bruto. Ainda falta a torre mesmo, ficou assim.

CAROLINA: Deixa eu fazer uma pergunta: o senhor tem memória de usar a represa sem ser para o trabalho? Vocês passavam fins de semana na beira da represa?

LELI: Para falar a verdade, os filhos e sobrinhos se divertiram bem comigo na represa. A gente pegava o barcão, levava eles; a gente pescava, fazia café no barco com a água da represa...

SOLANGE: E a gente acompanhava nas procissões; éramos todos crianças, e era dia de festa para a gente.

CAROLINA: Vocês têm essa memória positiva de estar perto da...

SOLANGE: Fazíamos piquenique, que está voltando à moda hoje; já levavam a comida de casa para comermos no piquenique.

LELI: Lá no Bororé, a gente ia e levava comida...

SOLANGE: O barco enfeitado com bandeirola.

CAROLINA: Deixa só eu entender, quando é que entra o motor no barco? Em que ano?

LELI: Em 1945 que eu comprei uma lancha com motor para puxar o batelão.

CAROLINA: Porque eu estou pensandor: antes do motor, o senhor levava o barco no remo...

LELI: É, nós íamos em dois, era difícil.

CAROLINA: Eu imagino.

LELI: Nós remávamos seis horas sem parar. Saia de lá para cima da balsa seis da tarde, chegávamos aqui na Prainha meia-noite, remando.

CAROLINA: E, em alguns lugares, venta muito na represa, não venta?

LELI: Venta. Quando o vento não dava contra, era bom, Se dava contra, tinha que encostar em um barranco, senão, ao invés de remar para frente, o vento levava para trás.

SOLANGE: E tinha a época da neblina, né, pai? Conta para ela.

LELI: A neblina é triste.

CAROLINA: Mas é de época ou sempre tem neblina?

LELI: A neblina aparece mais em dias mais curtos.

SOLANGE: Mas, antigamente, dava mais neblina e mais semana de garoa do que hoje. Eu tenho essa recordação de quando eu era criança; garoava umas duas semanas sem parar. E quando abaixava essa neblina, muitas vezes ele tinha que dormir no barco. Não tinha por onde andar.

LELI: Não tinha celular, não tinha GPS, não tinha 
nada. Se o vento segurava mesmo a gente, a comida ia acabando...

SOLANGE: Essa foto aqui é da igreja que...

CAROLINA: Essa é a dos 40 mil tijolos. Eesses tijolos vieram das olarias para onde o senhor levava lenha?

LELI: Era na olaria.

SOLANGE: Essa foto aqui é daquele primeiro sobrado aqui do Riacho. Aqui que tinha o armazém do seu Marino Betene que ele falou

CAROLINA: Onde é, isso existe ainda?

SOLANGE: Não, já desconfigurou tudo.

LELI: O sobrado? É onde é uma lotérica hoje.

CAROLINA: Uma lotérica?

SOLANGE: É aqui na rua principal, de onde você veio.

LELI: Lotérica do Baixinho.

CAROLINA: E a sedezinha da prefeitura e a biblioteca, isso já apareceu mais para frente?

LELI: É, vieram depois. Nos começos ali, quando eu trabalhava no barco, era tudo mato.

CAROLINA: E qual era a cara deste lugar, tinha um monte de sítio?

LELI: Cada um tinha uma área grande, que nem as colônias. No começo, os italianos vieram, tinha muito polaco aqui também.

CAROLINA: Antes dos italianos tinha os poloneses?

LELI: Acho que eram poloneses, sim. Tinha até um cemitério lá para cima da balsa que, no tempo dos polacos, teve uma doença meio feia, varicel-não-sei-o-quê. Tinha esse cemitério, enterraram lá mesmo.

SOLANGE: Teve uma turma que pegou, e morreu um monte de gente.

LELI: É, tinha um cemitério dos polacos para cima da balsa.

CAROLINA: Ah, estas duas fotos, trabalho e religiosidade. Gente, eu ainda estou impressionada com a quantidade de madeira que cabe nesse barco.

SOLANGE: Ele ficava baixinho também.

LELI: Ele tinha um metro e dez de calada, quando carregava, ficava com uns trinta centímetros.

CAROLINA: E esse barco você mandou fazer?

LELI: Não, eu comprei feito, mas tinha um português aqui que consertava, fazia; tinha um espanhol que ultimamente fez uma lancha grande.

CAROLINA: E onde se compravam esses barcos?

LELI: Olha, eu não sei.

CAROLINA: Quem eram os principais que trabaIhavam com os batelões? Havia outras famílias também? 
LELI: Tinha. No começo, tinha uns vinte batelões. Todo mundo vinha; uns levavam lá para Santo Amaro, outros para Alvarenga, outros vinham aqui para o Riacho.

CAROLINA: Tinha lenha, e distribuiam cada um para um canto?

LELI: Isso. Distribuía cada um para um canto.

CAROLINA: E aqui no Riacho tinha algum pierzinho que fosse só para descarregar, ou descarregava na margem mesmo?

LELI: Na margem mesmo, não tinha lugar certo, não. Tinha uns cinco metros de tábua, depois fazia pilha de lenha de baixo para cima; depois o caminhão encostava e jogávamos para cima. Aí, quando chegava com um batelão que cabia cinco pilha de lenha de 12 metros, 8 metros de comprimento por 1 metro e meio de altura, fazia as pilha

CAROLINA: O senhor vendia pelo tamanho?

LELI: É, vinha empilhadinha. E aqui [apontando para uma foto no jornal] sou eu falando.

CAROLINA: "Dois homens conduzindo 60 metros de lenha".

LELI: Se juntar dez da rapaziada de hoje, eles não fazem.

CAROLINA: Acho que não mesmo. Sabe o que eu queria saber? Vocês me falaram das festas, das pescarias e dos piqueniques de barco. Mas vocês se lembram se era comum tomar banho na represa no verão? Como diversão, lazer?
LELI: Na procissão a gente tinha três dias de festa: dia 20 de janeiro lá em Bororé; dia 3 de fevereiro, era dia de Santa Cruz, a gente ia ao Ângelo; e 7 de setembro era aqui, a procissão dos Navegantes.

SOLANGE: Saia de onde, pai?

LELI: Saia daqui da Prainha, ia para o Estoril, dava uma volta lá.

CAROLINA: Não tinha nada que separasse os dois lugares como tem agora?

LELI: Não tinha essa divisão.

SOLANGE: A dos navegantes é a que foi retomada.

CAROLINA: Vocês passavam por baixo da Anchieta.

SOLANGE: Essa divisão, fizeram para poder...

LELI: Segurar a água mais limpa.

SOLANGE: A água lá de cima é mais limpa.

CAROLINA: Ela tem até outra cor. E esta ponte aqui devia atravessar o rio; antes da represa tinha um rio, e já tinha uma ponte. Aí eles ampliaram essa ponte, certo?

LELI: Essa ponte foi feita quando a água começou a aparecer por aqui. O meu irmão ainda lembra que ele ia com o caminhão do meu pai. Ali onde tem a caixa d'água, e a rua bem por baixo, ali tinha uma subida, tinha o restaurante do João da Ponte, a gente apelidava de João da Ponte. 
CAROLINA: Porque ele estava ao lado da ponte?

LELI: É, porque ele estava do lado da ponte. Já tinha uma pontinha muito vagabunda, e o rio passava por baixo. Depois que fizeram a via Anchieta, essa via Anchieta acho que começaram a fazer em 1930 ou 1929, porque a água ia tomar toda aquela rua.

SOLANGE: Eles também acompanharam a construção da via Anchieta.

LELI: Meu irmão lembra bem, ele é dois anos mais novo do que eu. Essa via foi feita só com esguicho, essa via Anchieta.

\section{CAROLINA: Com esguicho?}

LELI: Desbarrancavam lá com água, bomba do rio, jogava lá, vinha aquela água suja com barro e tudo, iam bombeando até a água sair, ficando só a terra. Depois, a outra marginal já foi com basculante, máquina, foi mais profissional.

CAROLINA: Começou com uma pista simples, depois...

LELI: A via Anchieta, a primeira foi feita em 1945.

CAROLINA: Eu fui à Fundação Energia e Saneamento, onde tem algumas imagens da Light. Olha esta foto aqui, esta deve ser da época da construção da Anchieta.

\section{LELI: É.}

CAROLINA: Então, essa pontezinha aqui já é com a represa, o que o senhor está falando é de uma ponte mais baixa, quando tinha só o riozinho, é isso?
LELI: Etsa aqui eu acho que é lá no Rio Pequeno.

SOLANGE: A Estrada Velha, pai?

LELI: É, mas foi bem no começo.

CAROLINA: Sim.

SOLANGE: Não é a Estrada Velha?

LELI: É a Estrada Velha, deve ser, penso eu.

CAROLINA: Eu tinha entendido que a foto era da construção da Anchieta. Achei que esse morrão que a gente vê daqui, é esse morrão aí da foto.

SOLANGE: E aqui, nesse pedaço, seria a Balneária hoje.

CAROLINA: É, e pra cá o Areião. Realmente, a imagem é muito diferente.

SOLANGE: É aqui, pai.

CAROLINA: O tempo vira muito rápido aqui? Fica frio...

SOLANGE: Em outubro, novembro, não fez sol até agora, só fez uns dois dias de sol, outubro choveu todos os dias.

CAROLINA: Eu achei curioso, é quase verão, e aqui parece que ainda é inverno. Quem frequenta a represa atualmente? A Prainha fica lotada, não fica?

SOLANGE: No verão, sim. 
CAROLINA: O Ivar me falou que as pessoas não são daqui, do Riacho Grande.

SOLANGE: Sempre é gente de fora do Riacho. Então, é mais gente de fora que vem passar o dia...

CAROLINA: Vocês veem algum problema, tem algum conflito?

SOLANGE: O bairro não tem estrutura para tanta gente. O pior é o trânsito que se forma, como é uma única saída, complica muito o trânsito. Forma fila, junta com as pessoas que querem passar o dia na Estrada Velha, elas vêm para almoçar e também querem pegar o acesso da Anchieta.

CAROLINA: É um entroncamento.

SOLANGE: Fica fila até às quatro da tarde.

LELI: No fim do ano passado, teve um show que foi isso.

SOLANGE: Na Anchieta, às vezes, tem fila para entrar às quatro da tarde, para vir para cá.

CAROLINA: Para voltar para o Riacho?

SOLANGE: É, quando é hora do pessoal já vir voltando. A pior questão, eu acho que ainda é o trânsito, que a gente sente mais. Mas não tem estrutura, têm muito pouco banheiro.

CAROLINA: Fizeram uma reforma, colocaram um píer, mas falta banheiro público. E gente com criança pequena, como eu, faz o quê? Não dá para usar a água da represa porque é suja, nao tem banheiro, é complicado.
SOLANGE: É, então, o bairro não tem estrutura para receber tanta gente.

CAROLINA: Seu Leli, e esta foto aqui?

SOLANGE: Esta, eu acho que é a família da Anselma.

LELI: A mãe dessa aqui viveu 101 anos, quase 102. Em agosto, ela ia fazer 102. Ela faleceu em agosto. Aquela gostava de contar histórias.

CAROLINA: Perdi a chance de conversar com ela. Mas posso conversar com a filha. Onde as pessoas daqui são enterradas?

LELI: São Bernardo.

SOLANGE: Qual é o cemitério mais antigo?

LELI: O mais antigo é o Vila Euclides, o primeiro cemitério.

CAROLINA: O mais tradicional. É cemitério municipal?

SOLANGE: É.

LELI: Agora, você acredita que eu já levei defunto daqui até a Vila Euclides a pé?

CAROLINA: Como assim?

LELI: Carregando.

CAROLINA: Isso em que idade?

LELI: Carregando em quatro. Eu tinha uns 18 anos. 
CAROLINA: Fazendo serviço funerário, serviço de carregamento de madeira...

SOLANGE: Do outro lado da balsa, né, pai?

LELI: É, vinha até aqui de carretão, em cima do carro de boi, o carro de boi não ia pra lá.

SOLANGE: Aí, era na mão.

LELI: Muitas vezes, o defunto ficava na igreja, na capelinha que tinha, se vinha muito tarde, porque já estava fechado o cemitério. Aí, ficava para o outro dia. Pegava em seis, pegava três de cada lado.

CAROLINA: Devia ser pesado.

LELI: Pesado. Pior era o sapato; a gente tinha um sapatinho de borracha com sola de pneu; começava andar, começava a aparecer os pregos na sola. Rasgava o pé da gente, quando tirava o sapato tinha sangue no pé.

SOLANGE: Nossa Senhora, pai, que situação. Antigamente, todas as famílias daqui se conheciam, era parente de um, parente de outro.

LELI: Não tinha nenhum estranho.

CAROLINA: Então, o senhor carregava o pai de um conhecido, era tudo gente de família próxima.

LELI: É.

SOLANGE: Demorava dez dias de carretão até a balsa, né, pai?
LELI: É, e a turma trazia material com o carretão até aqui. Tem a Ângela Geonoto, que eu nasci ali. Nasci no Riacho mesmo, e na casa da minha mãe tinha um boteco...

\section{CAROLINA: Nasceu em casa?}

LELI: É, só tinha parteira aquele tempo. A turma trazia com o carretão, o carro de boi, descarregava carvão ali, depois a turma de São Bernardo carregava com caminhão e levava para São Bernardo, no começo.

CAROLINA: O senhor sente falta de alguma coisa dessa época?

LELI: A gente acha falta, era sacrificado, mas era divertido. Quando é novo, tudo é festa.

CAROLINA: É verdade.

LELI: A gente descarregava 60 metros de lenha até às quatro e meia, e depois ia jogar bola até escurecer; no outro dia levantava cedo.

CAROLINA: E estava novo no outro dia. Era uma vida mais saudável, não era?

SOLANGE: Ele até hoje tem saúde, não toma um remédio até hoje.

CAROLINA: Tem tudo a ver com exercício, disposição, fazer o que se gosta, ter boa alimentação. O que o senhor mais gosta de comer?

LELI: Tudo que aparece, a gente come. Eesse, nesta foto aqui, é meu irmão que tem 95 anos, quase 96... CAROLINA: Ele é o...? 
no seu tempo livre?

SOLANGE: É o João Vicentin, ele que reuniu algumas pessoas para poder fazer essas reportagens no aniversário de São Bernardo. A cada semana ele fazia uma reportagem com as pessoas que apareceram no dia que ele marcou esse encontro. Nós fomos da casa do Aldo, cada um contou um pouco a história, ele também foi gravando, para ele poder fazer essas reportagens sobre a história do Riacho.

LELI: E lembra de coisas, hein? 95 anos...

SOLANGE: Ele adora conversar, o negócio dele é bater papo.

Vera e Julio, frequentadores

da Prainha do Riacho

CAROLINA: Oi, tudo bem? Posso conversar um pouco com vocês?

VERA: Pode sim

CAROLINA: Qual é o nome de vocês?

VERA: Eu sou a Vera, ele é o Julio.

CAROLINA: Você é daqui?

VERA: Sou de Santo André.

CAROLINA: Em que ano você nasceu?

VERA: Em 1960.

CAROLINA: Como é o seu dia a dia? O que você faz

VERA: Eu sou formada em psicologia, dou aula e atendo em uma clínica. Tenho pouco tempo livre, muito pouco mesmo. Hoje é um dia atípico para mim, é meu aniversário.

CAROLINA: Ah, parabéns!

VERA: Por isso que estou aqui.

CAROLINA: Que delícia. E o que você gosta de fazer quando você tem tempo?

VERA: Eu gosto de ir ao teatro, eu vou com ele. Esse aqui é como se fosse meu irmão.

CAROLINA: Vocês são como uma família, vamos dizer assim.

VERA: ISSO.

CAROLINA: E para se divertir? Além do teatro, mais alguma coisa?

VERA: Teatro, exposição e vir aqui. Eu gosto muito de vir aqui, só que a gente não tem tempo, então vem quando é possivel. Gosto do Ibirapuera, de ir em Aparecida..

CAROLINA: No Paço Municipal de Santo André tem umas exposições superlegais, não tem?

VERA: Lá eu vou com mais frequência.

CAROLINA: Como você começou a vir para cá?

VERA: Foi através dele que eu comecei a frequentar. 
Ele que falou: "Ah, vamos lá no Riacho"; e foi assim que eu comecei a vir.

CAROLINA: Então, foi você que a trouxe pela primeira vez?

JULIO: Foi.

CAROLINA: Faz quanto tempo que você veio a primeira vez, você consegue lembrar?

VERA: Há dois anos.

CAROLINA: Conhece a história desse lugar?

VERA: Não.

CAROLINA: E você, já vem aqui há mais tempo?

JULIO: Venho desde criança.

VERA: Tinha uns 18 anos.

JULIO: Adolescente.

VERA: Ele já conhece mais.

CAROLINA: Então, se vocês tiverem um tempo, eu falo com você e depois com ele, pode ser? Você sabe como essa represa foi formada?

VERA: Não, sendo sincera mesmo.

CAROLINA: Você tem ideia se ela foi formada ou acha que ela sempre existiu?

VERA: Eu acho que ela sempre existiu, pode ser que eu esteja errada.
CAROLINA: Sabe se tem um dono?

VERA: Acho que não; não sei.

CAROLINA: Você acha que ela é pública ou privada?

VERA: Eu acho que ela é pública.

CAROLINA: Quem são as pessoas que usam? Você falou que veio pela primeira vez há uns dois anos, você veio alguma outra vez, deu uma olhada em quem são as pessoas que usam?

VERA: Então, é geralmente no meu aniversário que eu venho.

CAROLINA: E o que as pessoas costumam falar desse lugar? Seus amigos, por exemplo.

VERA: Que é um espaço muito gostoso, tem espaço para brincar, para nadar, tem a feirinha, que fui conhecer com ele.

JULIO: A feirinha era melhor até uns anos atrás. Já fui expositor muitos anos atrás. Ela era bem grande, e agora parece que deu uma diminuída.

CAROLINA: Que dia é a feirinha?

JULIO: De fim de semana, acho que no domingo.

CAROLINA: Você disse que as pessoas acham que aqui é um lugar muito agradável. Você concorda com isso?

VERA: Ah, eu concordo, até porque... 
CAROLINA: É seu aniversário. Para escolher estar aqui tem que ser por que você gosta, claro.

VERA: É, eu concordo. É agradável, sim.

CAROLINA: Como você se sente aqui?

VERA: Me traz paz, alegria, e traz muito conhecimento voltado ao ambiente. Aliás, tem locais que eu ainda não conheço aqui e que poderia até explorar mais.

CAROLINA: Quer dizer, dá vontade de querer conhecer.

VERA: É, de ir além, conhecer mais, até o ambiente.

CAROLINA: Essa represa faz você lembrar alguma coisa?

VERA: A minha infância. Tem muito a ver com a praia de Santos. E eu vejo crianças com animais, lembra um lago... Me lembra de coisas de criança mesmo. Quando a gente é adulto, lembra mais as coisas de criança.

CAROLINA: Interessante pensar isso.

VERA: Isso é o meu caso, mas tem tantas formas também... Mas me lembra muito da infância, lembra meu lado infantil mesmo.

CAROLINA: Como você chama esse lugar?

VERA: Eu falo: "Eu vou pro Riacho Grande".

CAROLINA: Já viu alguém fazendo alguma coisa estranha aqui?
VERA: Não. Mas estranho em que sentido?

CAROLINA: Estranho para você, porque "estranho" para cada um é diferente. Eu entrevistei um casal de Testemunhas de Jeová, e para eles o estranho era uma coisa. Para um jovem, é outra. Para você, o estranho talvez seja uma terceira coisa, ou você não viu nenhuma coisa estranha.

VERA: Não vi, nem roubo. Estranho pra mim seria isso.

CAROLINA: Você acha que algumas pessoas usam melhor o espaço do que outras?

VERA: Olha, eu vejo, por exemplo, tem um rapaz ali que pesca, ele está usando melhor que eu. Nós vamos andar ainda, mas ele está aproveitando mais, está ali pescando... Tem outros que estão no aquático, e acho que eu poderia estar também; nadar também seria possível, mas eu tenho um pouco de medo, será que a água é limpa?

CAROLINA: Eu ia até fazer essa pergunta, você acha que a água é limpa?

VERA: Eu acho que não, na minha opinião, não. Ele até pegou hepatite aqui.

JULIO: Há muitos anos...

VERA: É, muitos anos; mas foi, assim, logo depois que ele entrou na água.

CAROLINA: Pode mesmo ter relação direta com a represa. 
VERA: Pode, eu não acho que é limpo.

JULIO: Foi ali para o lado das balsas...

VERA: Mas quem garante que é limpo, digamos que eu faça uma pesquisa em relação à limpeza, eu não sei se é limpo ou não, só se alguém nessa pesquisa me falar: "É limpa".

CAROLINA: Devia ter um controle como tem nas praias?

JULIO: Eu acho que devia ter saneamento básico. Até porque eu não sei como é que funciona aqui, mas, essas pessoas pescando, elas pegam os peixes e vão consumi-los, ou devolvem para a água?

CAROLINA: Se essa pesca é esportiva ou se é...

VERA: É, tem isso também.

CAROLINA: Se você pudesse fazer algo para meIhorar, o que você faria?

VERA: Iria verificar a limpeza da água, se é potável. É nesse sentido que poderia melhorar. E devia ter monitores aqui. Por ser público, deveria ter; não sei se tem, você sabe se tem?

CAROLINA: Olha, eu achei curioso porque já vim aqui algumas vezes. No começo do ano, tinha sempre alguém, tinha um postinho de salva-vidas. Hoje não tem. E hoje é feriado, dia que vem muita gente, como é que o posto de salva-vidas não está aí? E achei muito estranho. Compartilho com você essa preocupação, e talvez também fosse uma sugestão minha de melhoria. Tem mais alguma coisa que você pensa que poderia ser feita para melhorar?
VERA: Seria a parte de limpeza, aí eu não sei onde entra... Seria essa parte, que eu não estou vendo, não sei nem se tem. Se eu viesse toda semana ou de 15 em 15 dias eu poderia até te falar.

CAROLINA: Mas a sua impressão é essa. E no fundo essa é uma conversa sobre impressões, sensações mesmo Você sabe quais são as turmas que frequentam aqui? Você prestou atenção nisso?

VERA: Sim. Vejo famílias com crianças, rapazes, homens, mulheres, de todas as idades, até idoso eu já vi.

CAROLINA: Tem uma cara de praia de certa maneira, não é?

VERA: Isso, exatamente.

CAROLINA: Todo tipo de gente?

VERA: Todo tipo de gente, animais até

CAROLINA: Animais correndo...

VERA: Vejo muito, e gosto também, amo animais. Eu vi um patinho ali.

JULIO: Cavalos...

CAROLINA: Eu vi uma turma à cavalo.

VERA: Eu vi, eles estavam ali, não é? Agora já saíram, mas eu vi; da outra vez eu também vi.

CAROLINA: Se você viu duas vezes e não vem com tanta frequência, provavelmente, eles estão aqui 
sempre. Eu achei muito legal, que delicia deve ser andar a cavalo na orla.

VERA: Tanto que quando eu cheguei eu comentei que se eu pudesse morar aqui, eu moraria. Porque eu acho muito tranquilo, e é o meu jeito de ser. Já ele comentou que não, ele gosta mais de um local agitado, para passear tudo bem. Eu moraria aqui, se eu tivesse condições financeiras para comprar ou alugar. O problema maior aqui também que eu vejo é a distância. Eu teria que vir de carro, ou de ônibus, mas nem sei como se pega ônibus aqui.

CAROLINA: Todo mundo com quem eu falei veio de carro. Imagina se tivesse ma linha de ônibus. Seria bom, não é?

VERA: Porque eu acredito que tinha um ônibus que saia de Santo André... Era de Santo André?

CAROLINA: Está aí uma boa pergunta.

VERA: É, porque agora eu parei para pensar: "Será que tem direto?". Eu acho que não. De Santo André direto... Será que tem? Eu acho que eu teria que descer em São Bernardo. Você é do ABC ou de São Paulo?

CAROLINA: Eu sou de São Paulo, capital. Com certeza tem linhas de ônibus que ligam o centro de São Bernardo até umas áreas aqui atrás, atravessando por Itaquaquecetuba.

VERA: Ônibus para a Prainha do Riacho?

CAROLINA: Isso não tem.

VERA: Eu sei vi de carro; agora, as pessoas têm que ter as opções também, se não tiver carro, por que não ir de ônibus? Quantas vezes eu saí de casa para ir para Santos de ônibus, muitas vezes de trem, que agora nem tem mais. Eu saia da minha casa em Santo André e ia de trem, que agora tiraram, tinha os horários, lógico, mas tinha.

CAROLINA: Era um destino, quando o lugar é um destino tem um ônibus ou um trem que vai para aquele destino.

VERA: Poderia ter aqui, eu acho até que mais pessoa viriam.

CAROLINA: Julio, você acha que tem um tempinho pra gente conversar?

JULIO: Pode ser.

CAROLINA: Você é daqui?

JULIO: Eu sou de Santo André, nascido em São Caetano, mas moro em Santo André.

CAROLINA: Em que ano você nasceu?

JULIO: Nasci em 1967.

CAROLINA: Como que é o seu dia a dia?

JULIO: Eu trabalho a semana toda; às vezes aos finais de semana também.

CAROLINA: O que você faz?

JULIO: A minha formação é em Ciências Contábeis, Letras e tenho pós. 
CAROLINA: E o descanso, ele acontece quando?

JULIO: Acontece aos finais de semana, sempre que eu posso. Também sou professor. Eu trabalho no setor de aprendizagem e sou palestrante em instituição. Faço tanto trabalho acadêmico quanto palestras, a parte administrativa...

CAROLINA: Você leciona a sua especialidade?

JULIO: Na realidade, além da aprendizagem você seleciona várias temáticas.

CAROLINA: E o que você faz quando tem tempo livre?

JULIO: Sou muito parecido com ela, gosto de ir a parques, mas sou bem eclético em relação a isso; ao mesmo tempo que eu gosto de ir a parques, eu gosto da noite, de dançar, ir ao teatro. Sou arte-educador, tudo que é voltado à arte me fascina, arte, exposições..

CAROLINA: Então, você gosta de passar seu tempo livre tanto em lugares fechados, como em lugares abertos.

JULIO: Sim, também gosto muito de shows, música. Gosto mais de música do que de TV.

CAROLINA: Que tipo de música você gosta?

JULIO: Eu sou bem eclético; só não gosto de funk, de resto...

CAROLINA: O que você acha da música que esta tocando aqui?
JULIO: Na realidade, eles tentam trazer uma música que agrade mais o público frequente. Então, é mais voltado para quem frequenta aqui mesmo, essas pessoas mais jovens, que tem mais esse gosto.

CAROLINA: Incomoda você?

JULIO: Não, não me incomoda.

CAROLINA: Quando você começou a vir aqui?

JULIO: Eu comecei a vir, eu devia ter uns 15, 16 anos de idade.

CAROLINA: Quem trouxe você pela primeira vez?

JULIO: Eu vim com os meus pais, meu irmão.

CAROLINA: Você consegue lembrar? Tem fotos dessa época?

JULIO: Fotos, não tenho, mas eu me recordo bastante. Inclusive o irmão dela vinha muito também. Nós vínhamos sempre com a família, e quando vínhamos ficávamos por aqui. É que antiga mente os passeios eram mais feitos em família. Nessa época, a família era mais unida.

CAROLINA: É, acho que para família com criança pequena é sim, com os adolescentes é mais complicado. Você sabe como essa represa foi formada?

JULIO: Não.

CAROLINA: De quem é essa represa?

JULIO: Também não sei. 
CAROLINA: Você acha que ela é pública ou é privada?

JULIO: Eu acho que ela é pública. Porque tem a parte que é da represa, e tem a parte que é do saneamento básico, não?

CAROLINA: Quem usa a represa?

JULIO: Acho que a população, não só a local, porque tem pessoas de outras regiões que vem para cá.

CAROLINA: Tem alguém que abusa?

JULIO: Você fala de abuso em que sentido?

CAROLINA: Na sua opinião, alguém que faça mal uso, que use de um jeito errado.

JULIO: Não vejo, não vi até agora nada voltado à questão de segurança para as pessoas que frequentam a represa, salva-vidas... Eu não vi...

CAROLINA: O que você ouve as pessoas falando esse lugar?

JULIO: Pelo pouco que eu sei, acho que elas gostam de frequentar aqui.

CAROLINA: E você concorda com o que elas falam?

JULIO: Eu concordo porque não vejo violência, não vejo nada que preocupe no sentido de assaltos, não vejo. Por mais que as pessoas... Independente de serem bem diversas, as pessoas se respeitam. Eu nunca vi agressão e nem nada disso.

CAROLINA: E você que vem há mais tempo tem bastante experiência para dizer afirmar isso...

JULIO: É, eu até brinco, eu tenho um primo que é quase meu irmão; ele é de Minas. Quando ele vem para cá, eu costumo dizer: "Acorda cedo no domingo e vem para cá, vem dar uma volta". Às vezes, tem a feirinha como eu te falei.

CAROLINA: É, eu fiquei supercuriosa com essa feirinha.

JULIO: Essa feira já foi muito boa, tanto que eu até já fui expositor. Era muito grande, tinha uma diversidade de artesanatos. Das últimas vezes que eu vim, ela reduziu bastante. Agora tem muita coisa industrializada.

CAROLINA: Acho que esta tudo muito industrializado, robotizado. Mesmo as relações entre as pessoas parece que só acontece nas mídias sociais.

JULIO: É, eu falo muito disso com os aprendizes, eles são todos na faixa de 14 a 24 anos, e a gente comenta isso, as pessoas ficam o tempo todo no celular. Qual é o sentido de sair em grupo se é pra ficar falando com pessoas que não estão ali junto, ao seu redor.

CAROLINA: E também essa coisa de gastar um tempo juntos sem estar ligado a outra coisa, estar no lugar. Como vocês: "Estamos aqui fazendo um passeio", enfim... Você veio aqui pela primeira vez com sua famíliam certo? Você têm fotos daqui de quando você era mais jovem?

JULIO: Eu acho que não tenho mais. Não moro mais com meus pais, minha mãe faleceu. Na casa do meu pai talvez tenha, mas eu mesmo não tenho. 
CAROLINA: Como você se sente aqui?

JULIO: Eu me sinto livre, como eu te falei, eu gosto dos dois lados, gosto muito da natureza e gosto muito de lugares fechados. Mas aqui eu me sinto livre, a gente vive no nosso trabalho, a sociedade cobra muito postura, a gente vive num ambiente de regras e comportamentos. Acho que aqui você está em um momento em que você pode ser você mesmo, ficar na natureza, fazer aquilo que gosta, não pensar em nada que seja cobrado no dia a dia.

CAROLINA: É esse o significado de tempo livre, não é? De que essa represa faz você se lembrar?

JULIO: Ela me traz paz, tranquilidade.

CAROLINA: Como é que você chama esse lugar?

JULIO: Riacho Grande mesmo.

CAROLINA: Quando você vai vir pra cá, você diz: "Vou para..."

JULIO: Vou para o Riacho.

CAROLINA: Você já viu alguma coisa estranha aqui?

JULIO: Não.

CAROLINA: Você acha que algumas pessoas usam esse lugar melhor do que outras?

JULIO: Depende... Eu faço aquilo que me agrada.

CAROLINA: Você sabe como é a qualidade da água?
JULIO: Olha, eu vejo as pessoas entrarem... Eu sei que ela tem uma qualidade que deixa a desejar, por isso que eu nem...

CAROLINA: Bom, você teve uma experiência ruim... Quando você teve hepatite?

JULIO: Nossa, faz uns 30 anos mais ou menos.

CAROLINA Nessa época, a qualidade da água era bem ruim mesmo. Houve muita mortandade de peixe, um monte de peixe que aparecia boiando na represa. Era porque o esgoto de São Paulo vinha pra cá. Se você pudesse fazer algo para melhorar esse lugar, o que você faria?

JULIO: Acho que realmente a questão da água é muito importante. E tinha que ter mais infraestrutura, ter mais banheiros. Eu tenho aprendizes e alunos que moram na região. Você pode ver que aqui tem duas vivências diferentes, aquelas pessoas que realmente tem condições financeiras e aquelas que não tem nada, que moram longe.

CAROLINA: ISso é bom, não é? Tem um caráter democrático. Como nas praias, quem quiser ir, vai.

JULIO: Você vê públicos diversos, você tem todo tipo de público aqui. É bem o que você falou da praia, todos se respeitam, independente de qualquer tipo de diversidade.

CAROLINA: Geralmente, qual a época que fica mais cheio aqui?

JULIO: Hoje não está muito favorável por causa do tempo, mas normalmente num dia bonito, que você consegue fazer piquenique, nem dá pra ficar 
aqui, a gente tem que atravessar para o outro lado.

GUIBSON: Eu trabalho.

CAROLINA: Entendi, fica cheio de guarda-sol e tudo mais?

CAROLINA: E com o que você trabalha?

JULIO: Fica cheio, o pessoal fazendo piquenique, GUIBSON: Eu sou orçamentista.

fazendo churrasco, os bares ficam cheios...

CAROLINA: Sempre trabalhou com isso?

CAROLINA: É, realmente, o tempo não está muito convidativo, mas ao mesmo tempo é gostoso. Eu pelo menos não sou muito de ficar em praia com sol não.

JULIO: Eu prefiro estar em casa.

GUIBSON: Não, já trabalhei em lava-rápido. Esse aí é o atual.

CAROLINA: E como você se diverte?

GUIBSON: Olha, eu trabalho durante a semana e fim de semana descanso.

Guibson, frequentador da Prainha do Riacho

CAROLINA: E o que você faz?

CAROLINA: Oi, posso conversar com você um pouquinho? Eu sou pesquisadora da USP, meu nome é Carolina, sou arquiteta e estou fazendo um estudo sobre a Prainha. Qual é o seu nome?

GUIBSON: Eu fico mais com o meu filho.

CAROLINA: Quantos anos tem seu filho?

GUIBSON: É Guibson.

GUIBSON: Vai fazer dois anos.

CAROLINA: Você é daqui?

CAROLINA: Qual é o nome dele?

GUIBSON: Sou.

GUIBSON: Ele se chama Brian Felipe.

CAROLINA: Onde você nasceu?

CAROLINA: E onde você mora?

GIBSON: Aqui mesmo.

GUIBSON: Vila Santa Teresa.

CAROLINA: É longe daqui?

CAROLINA: Em que ano?

GUIBSON: Não é muito não, uns vinte minutos.

GUIBSON: Em 2001.

CAROLINA: Como você veiopra cá?

CAROLINA: Como é o seu dia a dia? Você trabalha? 
GUIBSON: De carro.

CAROLINA: Que tipo de música você gosta de ouvir?

GUIBSON: Funk.

CAROLINA: E tem funk aqui na Prainha?

GUIBSON: Aqui não, mas em todo lugar tem.

CAROLINA: Mas não é funk que os restaurantes tocam, certo?

GUIBSON: Ah, mas aí são os restaurantes que colocam de música ambiente. Se eu fosse colocar ia ser o som so carro.

CAROLINA: Ia ser uma briga entre os carros.

GUIBSON: É, não pode.

CAROLINA: Antigamente podia entrar carro aqui, não podia?

GUIBSON: Podia.

Agora não pode mais.

CAROLINA: Como que você começou a vir aqui?

GUIBSON: Faz tempo, os meus pais vinham direto quando eu era pequeno.

CAROLINA: Quem trouxe você pela primeira vez?

GUIBSON: Acho que foi meu avô ou a minha mãe, não lembro.
CAROLINA: Mudou muito desde a primeira vez que você veio?

GUIBSON: Não, só isso aí.

CAROLINA: "Isso aí" que você fala é essa construção aqui atrás?

GUIBSON: É.

CAROLINA: Você têm fotos de você aqui pequeno? GUIBSON: Deve ter, mas só em casa.

CAROLINA: E você sabe como essa represa foi formada?

GUIBSON: Não.

CAROLINA: Sabe como se juntou esse monte de água aqui?

GUIBSON: Piorou.

CAROLINA: Depois eu posso contar um pouquinho como foi, se você quiser. E você sabe para que serve essa represa?

GUIBSON: Não sei, não.

CAROLINA: Talvez para você se divertir?

GUIBSON: Será que é a água que a gente' toma?

CAROLINA: Pode ser, pode ser... Você sabe de quem que é a represa?

Você acha que ela é pública ou privada? 
GUIBSON: Acho que é pública, tem tanta gente aqui...

CAROLINA: Todo mundo pode usar, certo?

GUIBSON: Todo mundo.

CAROLINA: Você que alguém abusa da represa?

GUIBSON: Tipo?

CAROLINA: Alguém que usa a represa de um jeito que você não acha certo.

GUIBSON: Tem vários, uns drogados aí, fumando, desrespeitando os outros.

CAROLINA:E o que as pessoas falam desse lugar?

GUIBSON: Falam que é bom, só que é muito sujo.

CAROLINA: Você acha que é muito sujo?

GUIBSON: Eu acho, podia ser mais limpo.

CAROLINA: Como é que você se sente aqui?

GUIBSON: Me sinto bem à vontade.

CAROLINA: Quem são essas pessoas que estão com Você?

GUIBSON: São meus amigos.

CAROLINA: Você vem sempre com eles?

GUIBSON: Não, é a primeira vez que venho aqui com eles. Mas eu venho aqui direto, não com eles, com a minha família.

CAROLINA: E o que essa represa faz você lembrar? GUIBSON: Antigamente, quando eu vinha com o meu avô.

CAROLINA: Como é que você chama esse lugar?

GUIBSON: Riacho.

CAROLINA: Já viu alguém fazendo alguma coisa estranha aqui?

GUIBSON: Já.

CAROLINA: O quê?

GUIBSON: Pessoas namorando ali dentro da água. CAROLINA: Você acha que algumas pessoas usam melhor do que outras?

GUIBSON:'Orra...

CAROLINA: O que você julga que é melhor, ou que é certo?

GUIBSON: Você curtir com a sua família, não mexer com ninguém, não sujar, essas coisas.

CAROLINA: Você sabe como é a qualidade da água?

GUIBSON: Deve ser péssima.

CAROLINA: Engraçado, porque olhando assim a água parece limpa, que ela não tem muita sujeira. 
Mas tem aquelas placas ali, certo? Dá peixe aqui?

GUIBSON: Dá.

CAROLINA: Que tipo de peixe, você sabe?

GUIBSON: Não sei, mas já pesquei aqui bastante.

CAROLINA: Dá bicho?

GUIBSON: Bicho você fala...

CAROLINA: Não sei, algum tipo de bicho.

GUIBSON: Nunca vi nenhum.

CAROLINA: Se você pudesse fazer alguma coisa para melhorar, o que seria?

GUIBSON: Limpar bastante aqui, contratar alguém para ficar olhando, não deixar os outros fumar.

CAROLINA: Se tivesse que dar um novo nome para esse lugar, que nome você daria?

GUIBSON: Não tenho em mente.

CAROLINA: Riacho está bom?

GUIBSON: Tá.

CAROLINA: E quem que são as pessoas que frequentam aqui?

GUIBSON: As pessoas que não tem para onde ir.

CAROLINA: Mas aqui é um lugar legal, não é?

GUIBSON: Ó, eu não tenho para onde ir, mas eu gosto de vir aqui, é mais perto de casa.

CAROLINA: Com que frequência você vem?

GUIBSON: Não venho muito pra cá, difícil eu vir, eu vou mais para a praia.

Andrea e Luiz, frequentadores

da Prainha do Riacho

CAROLINA: Oi, como vocês se chamam?

ANDREA: Eu sou Andre, e ele é o Luiz.

CAROLINA: Vocês são aqui de São Bernardo?

ANDREA E LUIZ: IsSO.

CAROLINA: Nasceram em São Bernardo?

LUIZ: Eu nasci em Santo André.

ANDREA: Eu também.

CAROLINA: Em que ano vocês nasceram?

ANDREA: 1985.

LUIZ: 1987.

CAROLINA: Como é o dia a dia de vocês? Vocês trabalham?

ANDREA: Ele tem o trabalho dele durante a semana, e o meu trabalho é um trabalho voluntário.

CAROLINA: O que vocês fazem para descansar, 
quando não estão trabalhando?

LUIZ: É mais TV, domingo em casa; televisão, tirar um cochilo.

CAROLINA: Vocês são casados?

ANDREA E LUIZ: Somos.

CAROLINA: Têm filhos?

ANDREA E LUIZ: Não.

CAROLINA: Eu já perguntei o que vocês fazem no tempo livre, mais alguma coisa? Por exemplo, hoje vocês estão aqui...

LUIZ: Então, hoje a gente acordou tarde, falamos: "Ah, vamos dar uma volta no Riacho, já que a gente mora aqui perto". Mas não é costume.

CAROLINA: Hoje é uma exceção.

ANDREA E LUIZ: IsSO.

CAROLINA: E vocês já tinham vindo aqui alguma vez?

ANDREA E LUIZ: Já.

CAROLINA: Vocês vieram como? Vieram de bicicleta desde a casa de vocês?

ANDREA E LUIZ: ISSO.

CAROLINA: E como é esse caminho?

ANDREA: É aqui perto do llha de Capri, a gente vem pela Anchieta, pelo canteirinho.

CAROLINA: Ah, tem tipo uma ciclovia lá?

LUIZ: Isso, mas não está acabada.

ANDREA: É, só tem até metade do caminho da pista.

CAROLINA: Quando vocês começaram a vir para cá para esse lugar?

ANDREA: Eu desde que mudei para cá, em 1996, desde criança.

LUIZ: Eu desde 1998, 1999.

CAROLINA: Quem trouxe vocês pela primeira vez aqui?

ANDREA: Foram meus pais.

LUIZ: Meus pais.

CAROLINA: Como é que vocês se conheceram?

ANDREA: É que nós somos Testemunhas de Jeová. A gente se conheceu dentro do Salão do Reino.

LUIZ: Nós nos conhecemos, noivamos e casamos lá. Já faz nove anos.

CAROLINA: Onde é a igreja que vocês frequentam?

ANDREA: Hoje a gente está na Língua de Sinais, de São Bernardo do Campo, que é ali na Assunção, não sei se você conhece a área verde.

CAROLINA: Depois eu vou procurar no mapa. Eu 
pergunto isso porque a sensação que eu tenho é que essa praia é usada pessoas de vários lugares.

ANDREA E LUIZ: É sim.

LUIZ: Vem gente de São Caetano, de São Paulo, pode ver as placas de carro e moto, não é daqui de São Bernardo, são de longe.

ANDREA: Eles têm como se fosse uma praia para eles mesmos.

LUIZ: Pode ver que tem algumas pessoas que exageram um pouquinho na vestimenta achando que é praia.

ANDREA: Usam biquíni, usam sunga.

LUIZ: E não é, né? É uma represa. A gente que mora aqui está acostumado, o pessoal que vem de longe, vê a água e acha que é praia.

CAROLINA: O conceito de praia é uma coisa muito ampla Por exemplo, em São Paulo, na Avenida Paulista, que começou a fechar para carros aos domingos, as pessoas começaram a ir de maiô também.

LUIZ: Só para pedalar, né?

ANDREA: Eu acho que é vontade de ir para a praia, né?

CAROLINA: Exatamente, a praia está mais na cabeça das pessoas do que no espaço. Então, vocês falaram que vêm aqui desde... Você desde 1996, e você desde 1999. Mudou muito de lá para cá?

ANDREA E LUIZ: Mudou.
ANDREA: Estruturalmente?

CAROLINA: É, ou estruturalmente ou com relação ao público que frequenta, ou algum outro tipo de mudança que vocês percebam...

LUIZ: Eu percebi foi que as barraquinhas não eram aqui, eram na areia mesmo; era meio bagunçadinho. Hoje ficou mais organizado, mas dá para melhorar muito mais, talvez limpar mais o espaço, fazer uma área de lazer, alguma coisa, mais vigilância talvez.

CAROLINA: É perigoso aqui?

ANDREA E LUIZ: A gente fica com receio.

LUIZ: A gente sabe que há risco em todo lugar, mas hoje é mais comum você ver alguém fumando alguma coisa errada em local público.

ANDREA: E por ser ponto turístico, vem muita gente de fora, então, a gente fica com medo de roubarem o celular ou qualquer coisa assim.

CAROLINA: Vocês vêm sempre durante o dia?

LUIZ: Sim, sim

CAROLINA: Durante o dia eu acredito que seja mais seguro, certo?

ANDREA: É, de dia tem menos bagunça.

LUIZ: E a noite é um lugar gostoso para vir, mas devido à segurança ninguém vem.

CAROLINA: Vocês já vieram jantar naqueles res- 
taurantes?

CAROLINA: E para as pessoas?

ANDREA: Não, eu não tenho vontade, particularmente, porque eu já acostumei, não tem graça. Ele, às

ANDREA E LUIZ: Também. vezes quer vir, já falou algumas vezes, mas eu não faço questão, não.

CAROLINA: E como as pessoas usam a represa?

CAROLINA: É mais por causa da comida?

LUIZ: Para banho, né, para brincar, se banhar, mas ela é imprópria.

ANDREA: Então, eu tenho receio da higiene, eu não sei se é um lugar muito limpo; pelo que eu vejo, não é.

LUIZ: Eu tenho amigos que já vieram e falaram muito bem, mas...

ANDREA: A gente vai mais para o Abadejo, da Índio Tibiriçá.

LUIZ: Que é uma região muito boa.

CAROLINA: Que é do outro lado, certo?

ANDREA: Isso, para o lado de Ribeirão.

CAROLINA: Vocês sabem como se formou essa represa? Como juntou esse monte de água?

ANDREA: Aparentemente, é pública.

ANDREA E LUIZ: Não.

CAROLINA: E o que as pessoas falam desse lugar? .

CAROLINA: E para que ela serve?

ANDREA: Quem não mora aqui perto tem muita admiração, mas a gente acaba acostumando.

ANDREA: Reabastecimento de São Bernardo e ABC.

LUIZ: Às veze, comentam: "Onde vocês moram?", CAROLINA: E ela não serve para mais nada, vocês acham?

"Eu moro ali no Riacho Grande", aí eles falam: "Pô, que legal, tem represa lá, tem parquinho". Ficam empolgados por a gente morar aqui, a gente não ANDREA: Para o meio ambiente, para os animais. 
ANDREA: É que nem morar perto de praia, aí quase não vai. Aí, quem nunca vê, acha que é um paraíso.

CAROLINA: Vocês têm fotos de vocês aqui?

ANDREA E LUIZ: Temos.

CAROLINA: De quando vocês eram pequenos?

ANDREA: Não, de quando eu era pequena, não.

CAROLINA: Você começou a frequentar a represa quando tinha uns 10 anos?

ANDREA: Isso.

CAROLINA: E vocês tinham o costume de tirar foto em família?

ANDREA: Sim, tinha minhas primas que vinham lá de Santo André, meus tios.

CAROLINA: Como é que vocês se sentem aqui?

ANDREA: Tirando a parte, às vezes, do medo de violência, a gente sente paz.

LUIZ: É uma região que eu particularmente gosto muito de morar, mesmo sendo tão longe do centro. Às vezes, a gente vai no centro, vamos supor, ali na Marechal, e não vê a hora de chegar em casa. A gente até brinca quando vai chegando perto de casa: "Voltou a camada de Ozônio".

ANDREA: É, é mais fresco, mais gostoso.

CAROLINA: Eu reparei que é muito mais úmido.
LUIZ: É, e quando é frio, é mais frio também.

ANDREA: O ar parece mais limpo. Em São Bernardo você sente aquele bafo quente vindo em cima de você, aqui é mais sereno o ar, menos pesado.

CAROLINA: E você falou que é mais frio?

LUIZ: Quando é no meio do ano, julho-agosto, aí é bem frio, bem frio mesmo, bem gelado, além da umidade que já tem, mas quando é frio, é bem frio mesmo, até de dia.

ANDREA: Mas aqui até parece outra cidade, porque quando a gente vai para o centro de São Bernardo, é outro ambiente, parece que é outra estação. A gente sempre sai agasalhado daqui e quando chega lá está sol.

CAROLINA: Tem um microclima aqui.

LUIZ: É, às vezes a gente brinca: "Quatro estações em um dia só".

CAROLINA: E o que essa represa faz vocês lembrarem?

ANDREA: Eu, particularmente, lembro quando vinha com as minhas primas, meus tios. Lembra um pouco isso: a infância, remete um pouco à infância.

LUIZ: É, para mim também.

CAROLINA: Qual é o nome que vocês dão para esse lugar?

ANDREA E LUIZ: Prainha. 
CAROLINA: Então, quando vocês vão falar para alguém, dizem: "Estou indo para a Prainha"?

ANDREA E LUIZ: Isso.

LUIZ: Essa é a expressão usada, não é represa, não.

CAROLINA: Vocês já viram alguém fazendo alguma coisa estranha aqui?

LUIZ: Ah, já.

CAROLINA: O quê?

ANDREA: Roubo e droga, bêbados, funkeiros, é isso aí. É falta de respeitar o meio público. Eu acho que tem certas coisas que não há necessidade de fazer na frente das pessoas, até questão de namorado...

LUIZ: Tanto homem como mulher, cada um é cada um.

ANDREA: Respeitar, independente da escolha sexual, mas acho que tem que respeitar quem está perto de você. Tipo, a gente é jovem e não tem uma cabeça de uma pessoa de mais idade, então, falta um pouco de respeito nesse sentido.

CAROLINA: Então, vocês acham que algumas pessoas usam bem esse espaço e usam mal?

LUIZ: Sim, a gente acabou de presenciar aqui: um pai com dois filhos vindo com um caiaque, sairam da água, pegaram o caiaque e foram para casa. E aí você pode ver que tem um monte de moleques fumando um negócio. Há dois tipos: um usou bem, pai de família; e os moleques, não. É assim que eu julgaria.
CAROLINA: Vocês sabem como é a qualidade da água?

ANDREA: A gente viu a placa que está imprópria para banho.

CAROLINA: E isso muda de vez em quando? Essa placa está aí sempre?

ANDREA: Não, foi recentemente, mas eu não sei quanto tempo faz que está aí.

LUIZ: É a primeira vez que a gente vê. Mas tem uma senhora lá no meio da água.

ANDREA: É, não adianta colocar a placa, o pessoal entra mesmo assim.

CAROLINA: É, imagina: a pessoa veio de longe, dia de descanso, está doida para dar um mergulho, ai... Dá peixe nessa represa?

ANDREA: Eu acho que dá, a gente estava até comentando.

LUIZ: É, tem muita gente que vem pescar, vem de longe, vem de madrugada.

CAROLINA: Se vocês pudessem fazer alguma coisa para melhorar esse espaço, o que vocês fariam?

ANDREA: Eu acho que falta um pouco mais de consciência até das pessoas. Coisas simples, você acumulou lixo? Leva embora. Por mais que tenha, olha, tem um monte de lata de lixo, de coleta de lixo, mas está aqui em cima. A pessoa que está com o lixo ali, não vai vir aqui. Não seria uma boa colocar 
mais lixeira; não sei se isso ajudaria ou se é caso de conscientização mesmo, de manter as coisas e não estragar.

LUIZ: Eu investiria em mais estrutura. Talvez uma ciclovia em torno dela toda, um espaço para o pessoal pedalar, correr, mais aparelhos de ginástica.

ANDREA: Até o caminho que a gente fez não está acabado, chega uma hora que acaba o cimento.

LUIZ: Mais segurança, policiamento, aqueles azulzinhos para cima e para baixo, talvez arrumar o espaço aqui, não sei, alguma coisa que seja refúgio para todo mundo, para trazer mais pessoas, quanto mais pessoas, gira...

CAROLINA: Sim, eu acho que trazendo mais pessoas, cada uma olha a outra, cuida pela outra. Essa coisa de segurança, quanto mais gente, mais as pessoas mal intencionadas se afastam: "Bom, eu não vou fazer isso na frente de todo mundo".

ANDREA: Mas aqui tem um negócio de polícia.

CAROLINA: É, tem uma base, mas eles não circulam.

LUIZ: É que, querendo ou não, quanto mais gente frequenta aqui, mais gira em torno do financeiro, do turismo, querendo ou não é uma área turística.

CAROLINA: Se tivesse um concurso para mudar o nome desse lugar, vocês teriam alguma sugestão?

ANDREA: Eu nem sei... É Prainha do Riacho Grande, né, acho que está bom do jeito que está.

CAROLINA: E quais são as turmas que frequentam aqui?

ANDREA: Mais jovem, né, Luiz?

LUIZ: É, jovem, pescador...

ANDREA: Depende do horário, igual a gente estava falando... A gente percebe que mais a noite vem mais molecada mesmo, mas quando o sol está mais forte, aí não tem jeito, eles vêm qualquer hora mesmo. Agora, mais idoso é essa hora, de manhãzinha, mesmo, que ficam ali pescando.

CAROLINA: Engraçado que eles estão sempre sozinhos, pescador está sempre sozinho, nunca está em grupo. É uma atividade meio solitária.

ANDREA: É, ele e a vara.

Tatieine, frequentadora da Prainha do Riacho

CAROLINA: Oi, tudo bem? Posso conversar com você um pouco? Qual é o seu nome?

TATIEINE: Oi... Pode sim. Meu nome é Tatieine.

CAROLINA: Você é daqui?

TATIEINE: Não, sou lá de Itapecerica.

CAROLINA: E onde você nasceu?

TATIEINE: Em São Paulo mesmo.

CAROLINA: Em que ano você nasceu?

TATIEINE: Em 1988. 
CAROLINA: Como é o seu dia a dia?

TATIEINE: Eu trabalho muito.

CAROLINA: O que você faz?

TATIEINE: Eu trabalho numa transportadora.

CAROLINA: E o descanso?

TATIEINE: Meu descanso é final de semana; ficar em casa com a família ou sair um pouco; que nem hoje, a minha amiga, ela conhece aqui e trouxe a gente para conhecer. Aí, os meninos pescam, e a gente vem conhecer a represa e ficar sossegado.

CAROLINA: Que legal, e o que você faz quando você tem tempo?

TATIEINE: Descanso, descanso.

CAROLINA: Mas tem alguma coisa que você goste mais de fazer para se divertir?

TATIEINE: Olha, churrasco. Não é uma diversão, mas é uma coisa que a gente junta os amigos e faz direto. Churrasco na casa de um ou de outro; a gente está sempre na casa deles mesmo, dos amigos.

CAROLINA: É uma forma de diversão muito boa.

TATIEINE: A gente não vai para lugares muito movimentados, a gente prefere mais o sossego. Aí, a gente está em casa de amigos aqui perto, é um lugar bom, um sossego.

CAROLINA: Que tipo de música você gosta?
TATIEINE: De tudo um pouco.

CAROLINA: Como você veio parar aqui hoje?

TATIEINE: Com uma amiga minha que já conhecia aqui. Ela e o namorado dela já conheciam aqui; aí chamaram a gente e outro casal para conhecer aqui hoje.

CAROLINA: Ela é da região?

TATIEINE: Não, ela também é de Itapecerica. Ela conheceu aqui, achou legal e trouxe a gente.

CAROLINA: E, até agora, o que você achou mais legal aqui?

TATIEINE: Eu não sei dizer, acho que é o lugar mesmo; o rio, o sossego, as crianças ficam brincando, não tem perigo nenhum.

CAROLINA: Você tem filhos?

TATIEINE: Tenho dois, estão no pedalinho. Eu já tenho um pouco de medo de ficar no meio da água. A minha filha foi com um pouquinho de medo, mas foi. Aquele ali é filho do outro casal nosso amigo; ele desistiu, ele voltou.

CAROLINA: É, porque fica lá no meio da água...

TATIEINE: Ah, eu não gosto não, balança muito.

CAROLINA: Você conhece a história desse lugar?

TATIEINE: Não, nunca ouvi falar. 
CAROLINA: Sabe como a represa foi formada?

TATIEINE: Não.

CAROLINA: Sabe para que serve a represa?

TATIEINE: Também não.

CAROLINA: Bom, talvez para passar o tempo, certo?

TATIEINE: É, andar de pedalinho...

CAROLINA: Você sabe de quem é a represa?

TATIEINE: Não faço ideia, nem sei se tem dono.

CAROLINA: Você acha que é um lugar público?

TATIEINE: Eu acho que é público; se fosse privado, a gente não poderia estar aqui. Vem quem quiser vir.

CAROLINA: O que a sua amiga falou sobre esse lugar antes de trazer vocês para cá?

TATIEINE: Ontem ela disse que conhecia um lugar muito legal, muito tranquilo, para a gente vir conhecer e passar o dia.

CAROLINA: E como você está se sentindo aqui?

TATIEINE: Tranquila, nada incomodando a gente.

CAROLINA: Essa represa faz você lembrar alguma coisa?

TATIEINE: Lembra rio, represa...

CAROLINA: Você é da cidade, mais urbana, não é?
TATIEINE: Sim, eu vou bastante para o litoral, mas ficar andando em rio eu nunca fui não. Eu não gosto muito de água, eu tenho medo.

CAROLINA: Você viu alguma coisa estranha aqui?

TATIEINE: Não, aqui não.

CAROLINA: Você sabe como é a qualidade da água daqui?

TATIEINE: Não, mas não parece ser poluída, não. Lá na frente está escrito que não pode mergulhar, mas aqui já não tem placa, não sei se é porque lá ficam os barcos, pode ser um pouco perigoso. Mas aqui não tinha placa de nada, tem gente nadando.

CAROLINA: Mesmo sendo essa sua primeira vez aqui, se você pudesse fazer alguma coisa para meIhorar esse lugar, o que você faria?

TATIEINE: Pergunta difícil, não sei, está bom assim.

Alexandre Delijaicov, arquiteto e urbanista, professor da FAU-USP, frequentador da represa na infância

CAROLINA: Certo, vou contar como estruturamos o trabalho de pesquisa desde que nós nos encontramos na qualificação. Tenho conversado com pessoas relacionadas, profissional ou pessoalmente, aos lugares que escolhemos como lugares de investigação: Cantinho do Céu e Riacho Grande. Riacho Grande já era um tema de interesse quando nós conversamos. Achamos interessante também trazer o Cantinho do Céu por ter se tornado, praticamente, 
uma nova cidade, de 40 a 50 anos para cá, dentro da cidade. Acho que havia as chácaras um pouco antes, mas eu estou falando de ocupação densa mesmo, $e$ a relação das pessoas com o lugar também é nova. Um dos interesses ali é entender como os projetos construídos à beira da Billings, o Céu Navegantes, o parque linear, interferem na relação das pessoas com a represa. Essa talvez seja a questão principal nos dois lugares: como as pessoas veem a represa; como as pessoas se relacionam com ela. Eu me lembro de você ter falado na minha qualificação: "Eu vivi muito a represa, eu navegava desde muito pequeno". Seria interessante, para mim, se você pudesse me contar suas histórias.

ALEXANDRE: Nos anos 1960, em 1967, 1968, muito pequeno, eu me lembro da represa. Cinquenta anos atrás, não existia a Marginal, e para chegar à represa tinha que ir de trem. Era um ramal da Sorocabana, que ficava na frente de onde é hoje a subprefeitura de Pinheiros. Tinha uma plataforma para os passageiros pegarem o trem que ia para Peruibe. Em época de chuva, era impossivel ir de carro para além do Autódromo, porque a estrada de Parelheiros era estreitíssima, asfaltada, porém estreitíssima, e fechada por um túnel de árvores da Mata Atlântica, tinha nevoeiro o tempo todo. Você conhece a região? Cidade Dutra?

\section{CAROLINA: Não.}

ALEXANDRE: A Cidade Dutra ficava um ou dois quilômetros depois do Autódromo, um quilômetro praticamente. Era um núcleo urbano, que seria onde fica hoje a estação de trem da CPTM; acho que o nome é Cidade Dutra mesmo. Era um empreendimento do pessoal que fez o Autódromo e o distrito industrial de Jurubatuba para os operários. Passan- do a Cidade Dutra não tinha mais nada, só a baixada do Rio Bonito, onde havia um posto de gasolina que era a última chance de abastecer antes da aventura até Parelheiros. Você já foi até Parelheiros?

CAROLINA: Já, há algum tempo.

ALEXANDRE: Parelheiros era o ponto final, onde acabava o asfalto. Se você fosse se aventurar de carro, era o momento de pôr corrente nos pneus, porque de lá em diante, em direção a colônia alemã... A colônia existe desde 1827, é muito antiga. A colonização alemã, por conta da relação que Dom Pedro teve com a austríaca-alemã, aconteceu no Brasil inteiro. Teve colonização alemã em toda Santo Amaro.

CAROLINA: Como Santo Amaro foi anexada a São Paulo? Foi nessa época também, não é, 1825, 1827?

ALEXANDRE: Eu não lembro direito, mas foi no início do século XX. Toda Santo Amaro tinha colonização alemã: Granja Julieta, Hípica... Então, essa região de Parelheiros era um lugar bem difícil de chegar. De Parelheiros até a colônia alemã eram oito quilômetros. Depois da colônia alemã até a barragem, quase na divisa Itanhaém-São Bernardo, mais oito a dez quilometros, ou seja, um total de 16 a 20 quilômetros. Esse era um dos caminhos de ferro que ligavam o Oceano Atlântico a São Paulo. Fui algumas vezes com os meus avós de trem. De carro era uma viagem superdificil: você tinha que ir pela Avenida Santo Amaro, até Socorro; depois ir pela Avenida Atlântica que era de terra, onde tinha a Garagem de Barcos do Artigas; e ir margeando o que seria a Avenida Atlântica hoje; para depois percorrer toda uma estradinha onde fica o Clube de Campo São Paulo, que é um projeto do Rino 
Levi e do Burle Marx. Mas ir de trem era muito fácil. Havia o trem de cargas e o trem de passageiros, que ia para Peruíbe e para Itanhaém. Também tinha o trem que ia por Rio Grande da Serra, mas esse não passava no lugar que eu frequentava. Acho que eu já falei, na sua qualificação, que era uma área de 60 alqueires, tinha uma represa, um lago artificial, uma barragem de 200 a 300 metros, que represava um espelho d'água de 200 por 300 com uma ilha. No meu imaginário infantil tem pedalinho, barco a remo e dois portinhos. Para uma criança, 200 metros de largura é gigantesco, Era um afluente da Billings, uma área de várias casas, sem energia elétrica e com um caminho de ferro. Não sei se você sabe, mas a Billings é uma máquina hidráulica para produzir energia elétrica. O Pinheiros, Pinheiros inferior, Pinheiros superior, a Billings como um todo e o reservatório Rio das Pedras são todos componentes de uma máquina hidráulica, cujo objetivo é produzir energia elétrica. E lá de Cubatão, onde fica a usina hidrelétrica, na borda, sobe um sistema de linhas de transmissão que passa exatamente pelo lugar que eu frequentava há 50 anos. Durante muitos anos, minha memória é de lampião a gás, apesar de ver as linhas de transmissão e um caminho de ferro. As balsas foram feitas pelo Billings, essa balsa do Cantinho do Céu é projeto do Billings, faz parte do projeto da Serra.

CAROLINA: São três balsas, certo? Bororé, Taquaquecetuba e João Basso.

ALEXANDRE: É. E esse lugar que eu frequentava, a barragem da colônia alemã, é uma barragem para represar a vertente marítima. Então, é um lugar muito importante, é a Capivari, uma das Capivari, uma barragem que tem uns 600 metros, um dique de 600 metros. Há coisas incríveis ali, por exemplo, o que hoje o pessoal chama de cratera da colônia alemã é um fenômeno astronômico, caiu um meteorito lá. Hoje, nós conhecemos o lugar como Ribeirão Vermelho, é um dos dedinhos do braço Taquacetuba, onde moram 40 mil pessoas e onde há um presídio. Quer dizer, o presídio fomentou a ocupação, a coisa mais absurda. Mas aquele lugar é um fenômeno astronômico incrível. Não sei se você já viu.

CAROLINA: Já vi. Você deu um curso do MIT lá, não é? Como foi esse curso?

ALEXANDRE: Foi ótimo. Nós até fizemos uma maquete; fomos até o lugar de onde se avista o mar. É um lugar que eu frequento há mais de 50 anos. Vou desde que nasci, mas me lembro mesmo de 51, 52 anos atrás. Acho que por causa da idade e da luz elétrica, a percepção que tenho do tempo agora é completamente diferente; antes parecia uma eternidade para ir até lá e uma eternidade para ficar lá. Eu gosto de dizer que conheço relativamente bem o lugar.

CAROLINA: Tem essa memória afetiva, desde criança...

ALEXANDRE: E tinha muita infraestrutura, apesar de na época eu não saber o que significava poder ir de trem, o privilégio de simplesmente ir de porta a porta.

CAROLINA: A Estação Evangelista fica antes ou depois de onde você descia do trem?

ALEXANDRE: Eu acho que a Evangelista de Souza é a última estação antes de onde eu descia.

CAROLINA: Quando você ia de trem, você descia... 
ALEXANDRE: Na parada 59, a 60 era a barragem; era uma parada antes da parada da barragem da colônia. Eram paradas excepcionais, no meio do mato, em sítios e fazendas. Provavelmente, toda essa região foi feita pelos construtores da ferrovia. Duas equipes de construtores acabaram ficando, os construtores da Light, da equipe do Billings, que construiu a represa e construiu aquela barragem, aquela barragem da represa foi feita pela equipe do Billings; e a outra dos construtores do ramal da Sorocabana. O que eu ouvi dos meus avós é que o lugar em que ficávamos tinha sido a fazenda de um inglês, tanto que tinha aquela coisa de criança: "o fantasma do inglês ainda cerca a fazenda, o inglês está solto por aí, ele é um plantador de batatas."

CAROLINA: Por que seus avós tinham uma propriedade lá?

ALEXANDRE: Eles faziam parte de um grupo de amigos que comprou uma fazenda antiga e construiu várias casas, uma para cada um.

CAROLINA: Tinha essa relação de ser um lugar para lazer, então?

ALEXANDRE: Dois dos amigos dos meus avós tinham essa ligação com o lazer. Um deles, eu lembro bem, era o dono do Leite Sol, uma empresa que produzia leite. Eles compraram a fazenda de um inglês, era o que eu ouvia na época. Hoje, estudando a infraestrutura, dá para entender que esse tal inglês ou era da equipe do Billings ou da equipe da Sorocabana.

CAROLINA: Você acha que ele era inglês ou canadense?
ALEXANDRE: Não tenho a mínima ideia, só sei que o lugar estava abandonado. Era um matagal quando eles compraram. Diziam que tinha sido uma plantação de batata, não sei se isso era gozação. Mas a verdade é que toda a Mata Atlântica ali não é original, foi tudo plantado. Outra coisa importante, acho que eu falei sobre isso na sua qualificação, é que no caminho até a barragem da colônia, quando não tinha nevoeiro, lembro que se via uma sucessão de chaminés das olarias; o caminho era repleto de olarias e serrarias. Cortar árvores é um fenômeno do Brasil há 500 anos. Os ingleses que construíram a Billings cortaram muitas árvores.

CAROLINA: É curioso você falar isso, porque eu vou conversar com um italiano, o senhor Quirino, que mora no Riacho Grande desde antes de alagar, e ele extraia madeira para alimentar as olarias e a locomotiva de trem, até o momento em que ela deixou de ser à lenha.

ALEXANDRE: Que idade tem ele?

CAROLINA: 93 anos.

ALEXANDRE: Lá era o tempo todo queimando, tinha sempre o cheiro de lenha queimando. Lembro que fazia muito frio. Parelheiros até hoje é um dos lugares mais frios de São Paulo. A temperatura chegava a $0^{\circ}$, coisa de fazer até geada, de o gelo cobrir tudo. Então, tinha fogão a lenha e tinha lareira nas casas que eu frequentava; a memória é essa. Na estrada inteira, depois que chegava na baixada, ou seja, nos rios, o que se via eram aquelas construções. Eu achava as olarias muito bonitas. Essas construções para queima de tijolo e telha são verdadeiras casas-forno. Você já viu fotos? Acho que é uma paisagem interessante para o que você está estudando. 
CAROLINA: Sim.

ALEXANDRE: A estrada ficava na várzea, no leito maior, ou seja, ela estava em um lugar relativamente horizontal, em contraposição ao mar de morros. Três horas da tarde, baixava a neblina, e por duas horas e meia mais ou menos a neblina ficava como um colchão de algodão na várzea. E as construções de tijolo vermelho sempre queimando, sempre soltando fumaça... O cheiro chegava a incomodar, mas não como o cheiro industrial, era só o cheiro de lenha queimando. Era uma devastação, aquilo já devia estar queimando há muito tempo.

CAROLINA: Você está falando isso, e eu estou aqui pensando... Vou conversar também com um senhor que comprou um sítio com uma casa casa holandesa. Quem sabe os tijolos dessa casa não tenham vindo dessas olarias..

ALEXANDRE: Os holandeses que migraram para cá ficavam na estrada velha de Campinas, onde está o clube deles; eles ficaram na região de Perus. $\mathrm{Na}$ verdade, o que aconteceu nessa região foi que, quando foi implantado o Riacho Grande, já existia esse Caminho do Mar. Onde está o dique da rodovia Anchieta, se você prestar atenção na planta, vaí ver que a Rua Vergueiro, que começa na Avenida Liberdade, segue pela Vila Mariana, cruza o Moinho Velho, depois muda de nome para Avenida Tancredo Neves. Lá em cima, quando ela cruza a Anchieta, continua por dentro dos bairros e vai até São Bernardo, até Riacho Grande, até a Estrada do Vergueiro, não sei se muda de nome, mas a estrada, o Caminho do Mar, existe por dentro da cidade.

CAROLINA: Sim. O Caminho do Mar continua cruzan- do Santo André, São Bernardo, até Riacho Grande. Quer dizer, antes da Anchieta já existia esse caminho.

ALEXANDRE: Esse caminho chegava lá na Prainha. Antes de existir o dique da Anchieta, a Estrada do Vergueiro chegava no Riacho Grande; depois continuava o Caminho do Mar, no tempo de Estoril, até chegar à casa de válvulas. Não sei se você já viu a casa de válvulas. Então, isso são duas infraestruturas gigantescas. É claro que a primeira infraestrutura é o Caminho do Mar, é a calçada do Lorena.

CAROLINA: Em estudos de antropólogos, há uma hipótese bastante forte de que tanto o caminho para subir a serra como a trilha tupiniquim foram aproveitados por Lorena para fazer a subida do litoral para o planalto. E uma parte era feita por água, certo?

ALEXANDRE: Só que não era um caminho, eram vários; e várias teorias dizem que o caminho de Parelheiros, o da barragem da colônia, é tão antigo que José de Anchieta costumava descer e subir para Itanhaém por aí. O caminho mais fácil para ir a Itanhaém é por Parelheiros. 


\section{Os técnicos}

Marcos Boldarini, arquiteto, dirige o escritório Boldarini Arquitetos Associados que desenvolveu o Projeto do Parque Linear Cantinho do Céu

CAROLINA: Estou fazendo um estudo sobre as situações de lazer na represa para fazer uma comparação entre duas situações na represa, uma delas na Prainha de São Bernardo, ali na barragem Anchieta, que já é há algum tempo usada para lazer.

MARCOS: Eu tenho duas urbanizações ali: um lugar que se chama Silvani Audi, que está em obras, e um lugar chamado Areião, antes do Rodoanel, que ainda está só em projeto.

CAROLINA: Conversando com meu orientador, pensamos em pegar um projeto já consagrado e com bastante documentação, por isso escolhemos o Cantinho do Céu. Eu tenho feito entrevistas com algumas pessoas de lá também. No dia em que você foi fazer apresentação do projeto no Mackenzie, eu já estava em contato com o Ferruge, por exemplo; quando você mencionou que ele não conseguiria chegar, eu mandei uma mensagem para ele, dizendo: "Você foi bem lembrado no Mackenzie".

MARCOS: Ele é superparceiro, é uma daquelas figuras que fazem as coisas ficarem em pé.

CAROLINA: É, me pareceu mesmo uma pessoa muito especial. Então, vamos lá, você pode me contar um pouco da sua formação?

MARCOS: Eu me formei em 1998, na Universidade Braz Cubas, em Mogi das Cruzes, e, desde 1996, venho trabalhando com o tema dos assentamentos precários. Trabalhei um pouco com gerenciamento, como estagiário, e depois como arquiteto. Fui intercalando outros programas e projetos do escritório, que existe desde 2000, e um pouco de atividade docente: dei aula na Braz Cubas e agora leciono na Escola da Cidade.

CAROLINA: Então, você não dá aula no Mackenzie.

MARCOS: Eu vou muito ao Mackenzie, mas não 
dou aula lá.

CAROLINA: Você me falou uma coisa que chamou muito minha atenção, você disse: "Eu acho curiosa a discussão sobre os mananciais; do ponto de vista objetivo, aquela não é uma represa que sempre existiu, ela foi construída". Como é que você vê isso?

MARCOS: Essa é uma inquietação mais recente, eu não coloquei energia para ir atrás de questões que não sejam do nosso campo disciplinar; então, para compreender uma série de exigências legais, como APP de 50 metros de borda de represa, é preciso pensar a represa como um sistema do ponto de vista natural, sujeito a leis ambientais. Como o tema daquele seminário no Mackenzie era o impacto das decisões ora relativas à habitação, ora ao caráter ambiental, sendo este último sempre o de maior peso e maior apelo, eu quis fazer essa provocação. O tempo inteiro fica esse ponto de vista normativo, que decide se vai haver ou não restrição a determinadas intervenções. E há um descompasso legal; a legislação estadual específica da Billings, e a legislação federal não conversam entre si.

CAROLINA: A específica da Billings é a de 2009?

MARCOS: Isso, de 2009.

CAROLINA: Essa que estabeleceu os 50 metros?

MARCOS: A exigência dos 50 metros veio do código florestal.

CAROLINA: O código florestal é bem restritivo com nascentes, certo? Mas na represa também se aplicam esses 50 metros?
MARCOS: Dependendo do curso da água e da largura, a APP pode ser de até 100, 200 metros; há categorias de restrição. A questão é: se sob o ponto de vista de um sistema ecológico ou de um bioma, não sei o termo adequado, estamos falando de coisas que realmente são relevantes. Eu penso que a sub-bacia é uma porção de terra gigantesca, e a gente fica brigando por 50 metros em volta da represa. Mas nunca houve vegetação de proteção dessa superfície, ela é um extrato. Enfim, minha intenção era fazer uma provocação: nós estamos falando de alguma coisa que vale a pena? Um espaço gigantesco foi ocupado, e eu fico aqui brigando na borda que é onde estão os mais pobres, onde estão as situações mais precárias, as regiões mais íngremes e que, óbvio, é o terreno que sobrou. É preciso discutir isso de uma maneira mais técnica do que meramente legal. Particularmente, eu não tenho condições de sustentar essa discussão até o final, porque acho que isso necessita de outros campos disciplinares.

CAROLINA: É, é um campo multidisciplinar.

MARCOS: Exato, mas acho que é uma provocação que precisa ser feita. No contexto do Mackenzie, por exemplo, tem o aluno do 1 \ semestre da graduação, tem o doutorando, tem o cara que está na prática há um tempão. Todos só tangenciam a responsabilidade, mas fica a provocação, faz-se um ruído.

CAROLINA: Achei muito interessante a sua fala; e queria saber: como vocês lidaram com isso no projeto do Cantinho do Céu?

MARCOS: O projeto do Cantinho do Céu tem uma equação muito singular; é um projeto que se inicia com uma ação civil pública em 2004-2005; quer 
dizer é um projeto anterior à lei estadual específica para a área. A restrição era maior; a lei específica foi um avanço, mas já precisa de uma revisão.

CAROLINA: Eu estava vendo umas fotos aéreas de 2010. Dá para ver a península do Jardim das Gaivotas e o aumento do número de casas de lá pra cá. São quase 10 anos, nos quais, evidentemente, muita coisa se transformou.

MARCOS: É, a ação civil pública de 2004 tinha a prefeitura e a Sabesp como rés, e a ordem do juiz foi: "Vamos desfazer o assentamento". Então, 1,5 milhão $\mathrm{m} \otimes$ tinha de ser desocupado, 10 mil famílias tinham de sair dali. Tudo bem, retiramos todo mundo dali, e para onde as pessoas vão? Mesmo que tivéssemos fôlego para uma ação como essa, bancando do ponto de vista econômico e social, o que faríamos com todo o entulho que restaria ali? Então, a prefeitura junto com o Ministério Público e a Sabesp começaram a desenvolver um projeto para a área, que foi o projeto básico usado na licitação de obras, a partir de uma licença especial. O escritório entra no trabalho em 2008 mais ou menos, com esse projeto básico e a incumbência de fazer as revisões necessárias para que as coisas caminhassem; todos entendiam que um processo como aquele era superdinâmico e pressuunha adequações e revisões. Como o projeto básico não tinha os sistemas de lazer e as áreas livres desenhadas, ficamos também com a incumbência de fazer toda a área verde.

CAROLINA: Vocês entraram via Sehab?

MARCOS: Entramos pelos contratos de obra, que tinham uma conta de acompanhamento técnico; era esse recurso que remunerava o escritório.
CAROLINA: Então foi um convite, não foi tipo...

MARCOS: Foi um convite, chamaram alguns escritórios.

CAROLINA: Eu fiquei com a impressão de que a Elisabete França tinha sido uma professora sua. Vocês tinham tido contato?

MARCOS: Ela que bancou esse projeto dentro da prefeitura. Na verdade, a coisa fica em pé antes dela, mas ela levanta as possibilidades legais dos contratos, de gerenciamento, e chega ao fim da passagem dela pela prefeitura com 40, 45 escritórios de arquitetura trabalhando para a secretaria de Habitação; desde o Marcos Boldarini até o Marcos Acayaba, uma turma de gente bacana.

CAROLINA: Acho essa decisão dela muito interessante. Na Prainha, por exemplo, houve licitação; às vezes, a empresa escolhida não é a que tem maior capacidade técnica ou a melhor visão. A questão é o preço, certo?

MARCOS: As licitações podem ser feitas de diversas maneiras, o concurso de projetos é uma modalidade de licitação da 8666. Eu não sou o maior defensor do concurso, porque nem sempre todos os concorrentes têm o traquejo daquilo que é obra pública. Mas de qualquer maneira o concurso é interessante. Pode-se balizar a licitação por técnica ou preço, não precisa fazer o pregão por preço. Há algumas maneiras de estruturar, mas nada garante a escolha da melhor proposta para aquela série de questões. Não sei como foi o contrato lá da Prainha, mas...

CAROLINA: Estou fazendo as investigações agora, começando a tocar no assunto. 
MARCOS: É preciso entender bem como acontece cada projeto.

CAROLINA: Quero fazer umas perguntas que eu faço para entender qual é a relação das pessoas com a represa: para você, para que serve a represa?

MARCOS: Em geral, as pessoas desconhecem essa região da cidade. Eu sou morador da Vila Mariana, antes morei na Freguesia do Ó e na Mooca. Nós não temos o hábito de usar as represas da cidade, às vezes, nem conhecemos as represas. São Paulo é muito grande. Hoje, é óbvio que a minha visão é completamente diferente, estou trabalhando há dez anos lá, é um contexto muito distinto. Acho que a represa compõe a paisagem, ela tem um papel do ponto de vista de estrutura ambiental muito importante e também poderia ser meio de transporte em algumas situações. Por mais limitado que seja o transporte a barco, a represa podia ser muito utilizada do ponto de vista do turismo, da recreação e do lazer; poderia ser a praia da cidade. Na Guarapiranga, por exemplo, na região de Interlagos, os alemães e os italianos que se instalaram ali no século passado criaram clubes náuticos nas margens da represa. Acho que o paulistano que não seja morador daquela região nem conhece o lugar. A Billings tem muito potencial; e ela ainda comunica seis municípios, então, é mais interessante nesse sentido. Para mim, é um patrimônio que precisa ser entendido nesse contexto.

CAROLINA: Quando foi a primeira vez que você foi lá?

MARCOS: A primeira vez que eu fui à Billings, eu era bem pequeno. la com meu pai, com meus tios, amigos do meu pai, que iam para pescar em São Bernardo. Em São Paulo, só conheci a represa quando fui trabalhar lá, na década de 1990.

CAROLINA: Aí já entra num contexto profissional.

MARCOS: É, eu morava na Região Norte, então ia mais para a Serra da Cantareira.

CAROLINA: Quem abusa da represa no seu ponto de vista?

MARCOS: É uma pergunta muito capciosa. Quem abusa? Não sei hoje se alguém abusa. Para mim, o grande abuso era a reversão do Pinheiros para dentro dela. Não há trabalho de saneamento, de urbanização que dê conta de suprir isso; parece que já há algum tempo a reversão não é realizada. Hoje, o que a gente tem é um processo necessário de intervenção do poder público, considerando os tensionamentos todos que estão colocados naquela região. Há processos de avanço e ocupação de novas áreas acontecendo constantemente.

CAROLINA: Minha grande inquietação é: como a maior empresa de saneamento da região metropolitana de São Paulo leva água para as pessoas sem coletar e tratar o esgoto? Esse para mim é o primeiro grande abuso.

MARCOS: Mas aí a pergunta é: quem abusa do Estado? Porque essa questão tem a ver com a cidade de Guarulhos, que tem um sistema autônomo de água e esgoto, mas é mais recente. A questão do saneamento é muito complexa; a solução que o Estado adotou nas décadas de 1960-1970 foi construir grandes estações de tratamento, que fazem com que o esgoto caminhe $70 \mathrm{~km}$ para ser tratado, 
o que torna o sistema dispendioso. A lei específica não permite o lançamento de dejetos na represa, então, não se podem instalar estações pequenas ali, por mais que a Sabesp se interessasse por essa solução.

CAROLINA: Os Céus não foram feitos com essa proposta, o Céu Navegantes não tem uma miniestação de tratamento lá dentro?

MARCOS: Não conheço bem a proposta dos Céus; isso precisaria ser investigado. Até onde sei, o Céu Navegantes foi construído em área de primeira categoria, e uma das questões foi construir uma estação de tratamento lá; sei que foi instalado um tanque, mas essa história eu não sei por inteiro.

CAROLINA: Não foi encontrada nenhuma maneira para conseguir...

MARCOS: Mas não existem sistemas descentralizados, não há pequenos sistemas de tratamento alternativos com lançamento direto.

CAROLINA: Mas isso por uma questão... Desculpa, só para eu entender, por causa da lei específica da Billings ou, na verdade, por ser uma questão complexa demais.

MARCOS: É uma questão supercomplexa, não atuamos na Sabesp para poder responder a isso. A lei específica não permite, esse é o primeiro obstáculo. O segundo é anterior à lei específica, trata-se do nosso sistema de saneamento, que foi estruturado de outra maneira. Não temos pequenos compartimentos de tratamento, tudo é levado para grandes estações. Isso não quer dizer que não exista responsabilidade da companhia de saneamento; a população paga uma tarifa de esgoto, mas não recebe o serviço.

CAROLINA: Exatamente, é uma equação supercomplexa essa. Mas quando eu pergunto por aí quem abusa da represa, algumas pessoas respondem: "quem usa o espaço para se drogar". Mas para nós que fazemos projeto e temos uma visão diferente da que tem o usuário do espaço, a pergunta se coloca em outro lugar.

MARCOS: Mas é uma pergunta muito capciosa, porque também se pode responsabilizar a prefeitura, por não ter criado condições ou políticas públicas adequadas para o atendimento de habitação; por não ter feito o controle urbano da ocupação do solo nos padrões adequados, independentemente se os padrões vigentes eram ou não interessantes; e por ai vai. Então, em menor ou maior grau, há muitos culpados nessa história. Por exemplo, talvez o morador que está há quatro décadas construindo sua casa, estabelecendo sua relação de vida ali, não se sinta responsável por nenhum tipo de agressão ao espaço. A resposta que cada um vai dar a essa pergunta é muito particular. Quando terminamos a primeira parte do parque, alguns moradores não queriam que pessoas de fora do bairro utilizassem o lugar.

\section{CAROLINA: Interessante isso.}

MARCOS: Eles queriam proteger o parque, diziam: "Vai vir gente de fora e vai bagunçar tudo". O Residencial dos Lagos, em especial, tem ruas internas que ligam os três assentamentos. A ideia era fortalecer essas conexões. Os moradores do Residencial dos Lagos não queriam conexão com o Cantinho do Céu por questões de grupo. Enfim... 
CAROLINA: É uma questão de identidade. A Melissa fala disso no mestrado dela, foi uma questão complexa com o nome Cantinho do Céu, inclusive, não foi? Quem escolheu esse nome?

MARCOS: No processo administrativo na prefeitura está Cantinho do Céu. A gente apanhou muito lá porque usava o nome. Eles reclamavam "Não, ninguém disse nada aqui ainda", e era verdade. Mas a prefeitura entende isso como um complexo.

CAROLINA: Você mudaria o nome por conta disso?

MARCOS: Hoje é difícil, já foi tudo regularizado, mas acho que é uma questão importante. Talvez devêssemos ter tido esse cuidado. Nós amadurecemos muito nesses 10 anos; amadurecemos como arquitetos. Aprendemos a dar importância às reivindicações das pessoas, porque líderes mudam, os grupos políticos que atuam na região mudam, os vereadores mudam. Em geral, o líder comunitário tem apoio de um vereador; essa é a lógica na cidade de São Paulo. A gente vai percebendo que, ano após ano, o apoio aos candidatos muda, muda de bandeira e tudo. Hoje, olhando para trás, é fácil perceber, na época não era.

CAROLINA: Você falou que são dez anos já, daqui a pouco está mudando a geração,

MARCOS: Até hoje é o maior contingente populacional e a maior superfície com que já trabalhamos. São quase 10 mil famílias, é muito grande.

CAROLINA: Quanto tempo durou o projeto?

MARCOS: O projeto não acabou ainda.
CAROLINA: Era aí que eu queria chegar: vocês dividiram em três partes, e houve uma parada, certo? O projeto já foi retomado, Marcos?

MARCOS: Estamos fazendo uma parte agora. Nós acertamos uma metodologia com a prefeitura bastante interessante. Como já existia o projeto básico, tudo bem que algumas áreas não estivessem desenhadas, mas do ponto de vista legal e de responsabilidade pública, entendíamos que era preciso dar um avanço a esta questão. Trabalhar numa superfície ocupada é trabalhar com o risco de perder o projeto e, em especial, o espaço público, muito grande. Fizemos a proposta ao poder público: "Vocês topam ir liberando as frentes de obra, e nós vamos fazendo o projeto em partes?". Então, definimos uma visão para o todo, como uma espécie de planejamento que tangenciava o projeto básico, em especial para a área do parque e das áreas públicas; e à medida que as remoções aconteciam, íamos trabalhando. Isso foi importante porque houve muita negociação. Gente que se consolidou, casa a mais que saiu, casa que cresceu. Nessa situação, a gente foi trabalhando em três momentos: trabalhávamos na ponta apoiando a liberação da frente de obra: "Olha, estamos com uma dificuldade de negociação, essa casa pode ficar?"; no meio, demolindo e tocando o projeto; e na outra ponta acompanhando a obra. Era o tempo inteiro numa dinâmica superinteressante, porque o desenho da prancheta passava pelo processo de aprovação da prefeitura e ia para a obra, isso fazia com que a minha base de trabalho fosse sempre a mais próxima possível do real. Então, eu tinha as diretrizes, o poder público sabia mais ou menos para onde estávamos indo, mas o ajuste fino ia acontecendo no dia a dia. Foi assim para as áreas livres e para as áreas de urbanização. Dividimos em seis 
partes, com subdivisões, e desenvolvemos, por exemplo, os projetos de infraestrutura, que eram a questão mais importante. A infraestrutura foi a obra prioritária, temos a maior parte da infraestrutura realizada. Temos um saldo de áreas a intervir, que são as áreas próximas da represa.

CAROLINA: Tenho um mapinha aqui que mostra todos esses trechos.

MARCOS: Eu dividi a urbanização em seis partes e fui subdividindo o parque em trechos, então, abrimos seis frentes. Por exemplo, eu tinha topografia acontecendo num lugar, e urbanização em outro. $\mathrm{O}$ projeto básico já existia, então, eram os ajustes para execução mesmo. Eu estava sempre o mais perto possivel da realidade, porque nós íamos andando com o projeto de acordo com as negociações de remoção. Foi interessante, foi um processo bem bacana. A parte um ainda foi subdividida em cinco trechos. Era assim: três quadras liberadas, porque oito famílias foram removidas; o serviço social negociando, porque essas questões não são simples; os caras demolindo; e a gente fazendo projeto. Era uma loucura, porque era o tempo todo pensando para frente, olhando para frente. Foi legal porque víamos o que não funcionava, e íamos mudando o projeto.

CAROLINA: Você acha que a ideia é que o parque continue na orla inteira da represa?

MARCOS: O trecho quatro do parque tem projeto pronto; hoje estamos fazendo o que é considerado o trecho seis; e o trecho um já está praticamente pronto. Ao todo são sete quilômetros. No começo do ano que vem, teremos mais da metade dos projetos para o parque. O engraçado é que os parceiros aqui no escritório vão mudando também; tínhamos uma equipe de 18 pessoas, e hoje somos três. Isso se reflete no desenho do parque também.

CAROLINA: Você se manteve sempre presente.

MARCOS: Para fazer esse projeto na escala e no nível de detalhe que a gente faz, é importante delegar. Todo mundo que trabalhou aí tem uma contribuição importante. Há uma linha mestra nessa história, um conceito, os fios condutores, mas há muitas contribuições. E é muito engraçado, porque você vai olhando e fala: "Agora aparece uma sinuosidade no meu desenho", e assim por diante. Conceitualmente, eu tenho minhas visões, mas você não vai ver uma mesma praça acontecer aqui, aqui, aqui, acolá. A gente está numa lógica de não reproduzir absolutamente nenhuma solução.

CAROLINA: Você disse que algumas coisas que experimentou não funcionaram, e você...

MARCOS: E não fiz mais?

CAROLINA: Pode me dar exemplos?

MARCOS: Fizemos um espaço que era, sei lá, de dança de rua, de capoeira, nunca funcionou. Fizemos um tabuleiro de dama no chão, nunca funcionou. Fizemos os pneuzinhos de bicicleta; eles foram utilizados até sumirem, ninguém repôs.

CAROLINA: E a mesa de pingue-pongue.

MARCOS: Essa mesa de pingue-pongue eles usam.

CAROLINA: Estava acontecendo uma oficina de marcenaria em cima da mesa. 
MARCOS: A pista de skate é sempre muito utilizada. Fizemos um lugar para bolinha de gude, essa coisa de brincadeira, brincadeira na terra. Nunca vi uma criança com bolinha de gude lá. Eles usam os espaços de maneiras diferentes do que planejamos. Houve a solicitação de uma quadra de bocha, que está do lado de lá da península, nunca vi ninguém jogando bocha lá. Os moradores não vão porque não querem andar 300 metros para jogar bocha na quadra. Aí você vai revisando.

CAROLINA: Esses programas de que você está falando apareceram em que circunstância? Nas oficinas que foram feitas?

MARCOS: Foi muito informal, tínhamos muita presença na obra. A prefeitura apresentou um programa mínimo, e várias ideias vieram de conversas com os grupos de esquina, nas ruas. Submetíamos as solicitações à coordenação do programa, e eles aprovavam ou não. O Ricardo Sampaio, coordenador na época, ia muito à obra; a Bete França ia muito à obra; tinha sempre bastante gente se envolvendo nessa história.

CAROLINA: Palpitando.

MARCOS: Palpitando, exatamente.

CAROLINA: O que pode ser também um grande desafio.

MARCOS: Mas de qualquer maneira, acho que fez parte de um processo importante. Não havia uma participação popular constituída, mas tínhamos a oportunidade de fazer esse trânsito de informação.

CAROLINA: Não era formal, mas, pelo que você está falando, as pessoas eram ouvidas.

MARCOS: Teve a história do cinema, por exemplo. A programação era uma quadra de futebol no local. O terreno era muito mole, e o geotécnico falou: "Olha não vale a pena fazer quadra aqui, vai ter duas quadras de areia um pouco a diante"; e eu fale: "Tudo bem, vamos tirar", eu estava lá no dia. A Vera Lúcia, que era a líder comunitária na época, estava a meu lado. Não sei por que veio o assunto de cinema, e eu perguntei para ela: "Esses meninos aqui vão ao cinema?", ela falou: "Boldarini, quanto custa um cinema?". Então, a gente propôs a escultura para pendurar uma tela. Houve duas sessões lá. A história toda vai se construindo dessa maneira, se isso não virar um espaço de cinema, vira uma brincadeira, é uma escultura, tem ludicidade, e por aí vai. São situações assim que fomos incorporando, e várias ideias foram aparecendo. Também tem o pessoal que cuida muito da horta. Eles pediram para deixar um canteiro maior, é um lugar em que se planta sem critério nenhum, mas a moradora está lá, sempre cuidando. Tudo depende da presença que você tem nos lugares, da vontade e capacidade de perceber e ouvir. Acho que essa é a maneira mais adequada para esses contextos; é uma postura nossa.

CAROLINA: Entendendo que são dez anos de projeto, e que você continua presente, fazendo os outros trechos, quais são as diferenças e apropriações que você observa?

MARCOS: A apropriação dos espaços é excelente, e há pouquíssima modificação. Em especial, há limite e contorno claros do que é público e do que é privado. A gente não tem avanços que sejam significativos, é uma ou outra situação pontual. Há todo tipo de apropriação do espaço: gente que não 
é da região indo pra lá, gente que é da região indo, já houve manifestações de ocupação espontâneas ou organizadas. Tem ginástica para a terceira idade num deque, inclusive isso está fotografado e está no livro. Não tem um dedo da prefeitura nisso, os moradores que se organizaram. E acho que há manifestações de oposição também, é só ver a maneira como os grafiteiros foram se apropriando desses espaços.

CAROLINA: Eu ia falar sobre isso. Os painéis já estão todos...

MARCOS: Os painéis estão todos descaracterizados. Acho que essa história é superdelicada. Convidamos um artista de fora para fazer os painéis. Ele não conhecia os grupos atuantes do lugar, e isso deu ruído. Mas também já tentamos organizar com os grupos de lá e não conseguimos. Não é simples fazer acontecer. Mas acho também que é uma questão da cidade toda. Eu particularmente acho que o grafite precisa ter um determinado controle, se não ele vira ruído. Já conversei com os grafiteiros de lá, e em algum momento eles concordam comigo; o Ferruge também concorda. Por um lado, acho que nossa percepção falhou; por outro, também acredito que, às vezes, há ali uma maneira meio arbitrária; a transgressão se opõe às solicitações que os próprios grupos fazem.

CAROLINA: Eles falam muito no atropelo... Inclusive aí entra outra questão, que é a pixação.

MARCOS: O problema lá é a pixação, não é o grafite.

CAROLINA: A sensação que eu tive é que são as duas coisas.

MARCOS: Sim.
CAROLINA: Eles usaram o painel como suporte para as duas coisas. Não sou especialista no assunto, mas sei que a questão é muito dinâmica; há vários componentes.

MARCOS: Também não sou especialista. Tentamos um diálogo; pensamos numa viela de grafites, eu chamei os caras aqui no escritório e falei: "Olha, podemos trabalhar juntos, eu tenho uma percepção para o lugar" (e mostrei os desenhos) "duas escalas de muro, uma mais alta e essas mais baixas.

Vocês topam? Minha ideia é que o azul do céu entre nas paredes mais altas, laterais de casa de três, quatro andares, então, num dia de céu muito azul vai se formar um túnel à medida que você olha de cima ou de baixo para cima. Os muros de rampa ou escada, que estão na altura do olho, a gente pode dividir entre os artistas". Eles não conseguiram se organizar, e a resposta que tivemos foi: "Ó, não dá para organizar porque os caras vão lá, são artistas e fazem o que querem". Eu falei: "Bom, então, vocês façam sozinhos, vocês vieram pedir apoio, eu tentei organizar".

CAROLINA: São as contradições, não é?

MARCOS: São as contradições. Aqui entre nós, extraoficialmente, eles fizeram um orçamento que era um despautério, pediram 50 mil mais uma lista de material com 400 bicos de spray. Eu perguntei: "Vocês vão comer isso que nem pipoca?". Eu estava convencendo o gerente da construtora a fazer; ele não tinha recurso em planilha, mas ia fazer como um plus para a obra dele. Eu falei: "Eu vou mandar pra frente, eu conheço o gerente, ele vai dar um grito lá no Grajaú que eu vou escutar aqui na Paulista", e foi isso o que aconteceu, mas viabilizou. Depois, 
eles disseram: "A gente podia pedir o valor que quisesse"; eu falei: "Isso não existe, são 50 mil ou nada, ou vocês estão me chamando de trouxa?".

CAROLINA: É, isso foi antiprofissional, eu entendo.

MARCOS: Em grande parte, o resultado do grafite é muito ruim, esteticamente falando. Pouca gente sabe fazer muito bem, tem bons artistas lá, mas, às vezes, o resultado é muito ruim, às vezes é naîf. Isso é espaço público, precisa de algum controle. O painel tinha uma relação com as edificações que já existiam ali; intensidades de cores, cujo pressuposto foi rebater o uso do espaço que está embaixo, mais quente e agitado em um lugar, mas frio e tranquilo em outro. Também era para ser uma referência do limite entre o público e o privado, o painel tem uma proposta.

CAROLINA: Tem um raciocínio profissional.

MARCOS: Sim; certa ou errada, não sei dizer, mas tinha uma proposta. E o Maurício Adinolfi ia conversando com os moradores das casas, perguntando: "que cor você quer". Foi um processo para todo mundo, acho. Não sou a pessoa mais afeita ao grafite, acho superlegal, mas pra mim é como cachaça, tem que ter moderação.

CAROLINA: Acho que tem aquele momento em que, como arquitetos, pensamos: "Poxa vida, nossos saberes e nossa formação podem contribuir com algo, certo?". Fazemos determinada proposta com base em saberes específicos.

MARCOS: Pois é, pensamos o espaço de uma maneira... E não somos contra a cor, somos bem coloridos. Mas o parque é para todos os grupos. Ok, daria para ter feito de outra maneira? Claro! Mas as muretas mais baixas não têm uma cor neutra à toa; fomos definindo gradientes no embasamento para destacar o fundo; sempre pensando no todo. A manifestação pseudoartística do grafite ou do picho, com "- $\mathrm{CH}^{\prime \prime}$, que é diferente do pixo com "-X", se coloca de outra maneira. Em alguma medida essa manifestação se sobrepõe a todos os outros grupos; atende uma faixa etária específica. Entre os idosos, por exemplo, muitos não curtem o lugar com "cara de sujeira". Mas, de novo, eu e minhas limitações; sempre acho que a gente vai errando e aprendendo no processo.

CAROLINA: E acertando depois, mais para frente. Mas me conta como se deu a continuação entre a gestão que terminou em 2012, depois veio a gestão Haddad em que não aconteceu nada, e a prefeitura de agora. Como tem sido essa transição?

MARCOS: Temos sido muito respeitados; acho que é uma condição que conquistamos. E como nosso mundo não é muito grande, o que acaba acontecendo é que encontramos conhecidos em todo lugar. Na gestão do Haddad, eu ia trabalhar em mananciais com uma pessoa com quem já tinha trabalhado em outro lugar na gestão da Marta Suplicy. As pessoas que assumem a coordenação dos trabalhos nos mananciais tratam a intervenção com bons olhos. A exceção foi o período do Haddad, porque tinha uma turma muito pouco acessível ali do PP, e não tinha conversa para nada, não era nem bom nem ruim.

\section{CAROLINA: Do PP? Onde?}

MARCOS: Na secretaria de Habitação, na Sehab. Até o João Whitaker assumir...

CAROLINA: É, eu ia perguntar: em algum momento 
o João entrou?

MARCOS: O João chegou no último ano, chegou numa situação muito difícil, no final de gestão, sem recursos. Ele viu as prioridades e fez, conheço o João. Depois, veio o Mário Reali. Você conhece o Mário? Ele é arquiteto, foi prefeito de Diadema. Eu já tinha trabalhado para ele em Diadema, fazendo urbanização; a mulher do Mário já tinha trabalhado aqui. A gente conhece as pessoas. Não tive nenhuma dificuldade. O problema foi que parou, andou, parou, andou.

CAROLINA: Mas teve sempre uma continuidade.

MARCOS: Sim, mas óbvio com contornos diferentes.

CAROLINA: Mas não foi totalmente abandonado, certo?

MARCOS: Não. A crise de recursos do Governo Federal paralisou tudo; não foi paralisação deste ou daquele projeto. Na gestão do Haddad, acho que a intenção foi tirar poder da Sehab por uma questão política. Tinha a nomeação do Partido Progressista, que era um acordo político.

CAROLINA: Coligação, a maldição da coligação.

MARCOS: Não tinha recurso na Habitação, mas no Planejamento tinha o Fernando Melo Franco, e grande parte das decisões de Habitação foram para as mãos dele. Olhando de fora, o acordo político foi cumprido. Eu, que trabalho com essas questões políticas, acho que tem de cumprir mesmo. Se tem uma coisa que é importante na política é cumprir os compromissos; isso o Haddad fez e, particularmente, acho positivo, por mais que eu tenha odiado a escolha.

CAROLINA: É. Curiosamente, o Kassab foi para o Ministério das Cidades. Todo mundo xingou o Kassab, falou mal dessa nomeação, mas acho que do ponto de vista da gestão, sobre o problema dos mananciais, ele merece parabéns.

MARCOS: A grande crítica eram as remoções, mas, extraoficialmente, tinha um supertensionamento político ali. Eu fiquei bravo quando saiu o Observatório das Remoções, do LabHab, e a foto de capa era esse projeto. Não tinha crítica negativa, mas eu fiquei bravo; estou envolvido no projeto. E eu já conversei isso com o João, já conversei isso com a Carina Leitão.

CAROLINA: Acho que tem uma tensão entre a Bete e o LabHab.

MARCOS: Isso, aí fica essa polarização, eles se odeiam. Eu me dou bem com a Bete, tem uma questão quase de mãe e filho. Ela me pegou na faculdade, no quarto período, foi minha professora de desenho; depois foi minha orientadora de graduação; e depois me deu trabalho. É uma relação de confiança de 20 anos. E com o João também, a gente se respeita muito, acho o João ótima pessoa, um excelente quadro. E você fica no leva e traz, escuta de um lado, escuta de outro.

CAROLINA: Eu tenho vontade de dizer: "Gente, o inimigo é outro". Estamos com o governo do Bolsonaro. Quem é o verdadeiro inimigo?

MARCOS: Esse, com certeza, é o verdadeiro inimigo. Talvez, o Bolsonaro tenha sido eleito, inclusive, porque esses dois lados ficaram se estapeando 
loucamente a vida inteira.

CAROLINA: Exatamente, aí chega este momento que tem que ser de dar as mãos e não acontece. Desafios técnicos, eu imagino... Vocês devem ter passado por vários.

MARCOS: Os desafios técnicos existem, mas os desafios aí são mais de gestão social, de como a história anda. Desafio técnico não é nada. No piso de cimento intertravado podem existir as questões de madeira, mas se topar fazer, tecnicamente, não é nenhuma grande questão.

CAROLINA: Vocês fizeram poucas obras de contenção, certo?

MARCOS: Sim. Fizemos sempre para ir compondo planos, e criando situações melhores de infiltração.

CAROLINA: Foi feito em quê, bloco de cimento?

MARCOS: Bloco de cimento.

CAROLINA: Intertravado?

MARCOS: Em alvenaria armada; são todos revestidos. E fomos fragmentando as estruturas. São poucas as estruturas altas, até porque queríamos criar um pouco essa acomodação com o terreno, e para que esses lugares fossem mais propícios à infiltração da água. Tomamos essa decisão mesmo entendendo que o desempenho nessa região é pouco, porque o lençol freático é alto, e o solo é argiloso. Mas caminhamos sempre para a decisão mais adequada; é a nossa visão. Introduzi, por exemplo, o piso intertravado drenante. A conversa começou aqui, com o fornecedor; não existia essa ideia na planilha pública. O fornecedor construiu toda uma articulação para inserir o piso na planilha. Dois anos depois, conseguir fazer um trecho perto do cinema, e foi superlegal. Eu fazia uma cena, às vezes, vinha com um pouco de água na mão, ou pedia para algum morador trazer água, jogava perto das pessoas e a água desaparecia. Era uma brincadeira. Até mesmo para avançar nas discussões, porque esse piso é mais eficiente que o próprio solo, a capacidade da água de percolar nele é maior. Mas essa história aconteceu em 2010 para 2011, então tentar inserir um material demorou três anos, porque ele não estava na planilha pública, e por isso não dava para especificar. Entrou na planiIha da SeUrb primeiro, daí chegou ao coordenador da Sehab. Ele foi ver a questão técnica, ponderou sobre o preço, que era um pouco mais caro, avaliou o benefício, e pediu para azer o teste. Mas não foi nenhum grande desafio técnico. Os desafios estão em outras disciplinas; e os processos de erosão estão em outro lugar, nas encostas, nos locais em que há movimentação de água...

CAROLINA: E o projeto de coleta de esgoto? Deve ter mil postos aí...

MARCOS: Você tem sempre uma linha levando para o sistema de bombeamento, que são as estações elevatórias. Usamos a gravidade; daqui vai para um coletor, que leva para outra estação; e aí vai mecanicamente em saltos até o...

CAROLINA: A tubulação de recalque foi feita durante toda a pavimentação, certo? Tinha alguma estrutura já?

MARCOS: Não tinha nada, o projeto de saneamento pressupõe muitas relações. Quando alguém vai 
pensar no saneamento aqui, é preciso entender que tudo vai se conectar a um sistema coletor, que vai levar para uma estação. Tem que integrar o projeto de saneamento àquilo que a Sabesp já construiu.

CAROLINA: Eu tenho uma curiosidade sobre a Prainha. Não sei se vou ter acesso e tempo para conversar com a Sabesp, mas a miniestação de tratamento atrás da Prainha é uma escolha muito infeliz, você concorda? É uma praia que tem cheiro de esgoto permanentemente.

MARCOS: Mas a Prainha teve um projeto de urbanização, há muitos anos mexeram nas ruas, não mexeram? Tem uma intervenção mais recente e tudo.

CAROLINA: Sim, mas eu estou dizendo isso porque, em algum momento, eu gostaria de entender como essa decisão foi tomada, por que escolheram aquele lugar.

MARCOS: A unidade da Sabesp fica em São Bernardo, talvez dê para falar com o gerente para entender a lógica do projeto. Fizemos a urbanização do Areião, a Anchieta passa aqui, a Prainha está aqui, o Rodoanel passa aqui. Na área em que trabalhamos, há duas sub-bacias, uma de mananciais e a outra é o Tamanduateí. O esgoto caminha até passar por baixo da Anchieta e cair em um sistema que chama chrysler, esse chrysler vai para o Silvina, que é na outra bacia, onde tem uma estação de água da Sabesp. Agora, a localização dessa estação na Prainha, provavelmente, tem uma razão técnica; tem que ver se essa razão conversou com o urbanismo.

CAROLINA: Eu tenho pouca informação, estou começando a entrar agora no assunto, mas aparente- mente é uma ideia muito ruim, colocar uma estação de esgoto num lugar que é...

MARCOS: Mas essa turma não está preocupada com isso, é uma outra lógica.

CAROLINA: Minha grande questão é: as pessoas sentem prazer de passar o tempo na represa, pescando, tomando sol... Então, por que não se pensa nisso? Por que não não se trabalha com várias disciplinas envolvidas para que se constitua efetivamente um patrimônio social?

MARCOS: Não sei dizer, é realmente a pergunta de um milhão de dólares. Nós temos uma atuação muito pontual, eu tento sempre me colocar no papel ao qual estou designado, sou bem disciplinado com isso. Quando eu chego para atuar, a política já está estruturada, quando entramos em um momento anterior, dá para contribuir. Aqui, já está tudo estruturado. Acho que o resultado do Cantinho do Céu é uma equação de um pouco de vontade pública e do fato de o escritório querer fazer.

\section{CAROLINA: Foi ruim de dinheiro?}

MARCOS: Não foi ruim, mas foi longe de ser o que deveria, porque é um projeto remunerado por desenho. Eu não recebi nem um real por nenhuma hora técnica nesses dez anos que eu vou lá. Nunca recebi um litro de gasolina, não tinha acompanhamento de obra, mas não deixei de ir.

CAROLINA: Era a paixão que movia você.

MARCOS: Era paixão; era um pouco por entender a importância de um trabalho como esse; um pouco para construir uma trajetória; era por ter responsabi- 
lidade com as coisas... Hoje, de verdade, eu estou um pouco cansado; se tiver que ir até o Cantinho do Céu...

CAROLINA: Uma hora e meia de trânsito.

MARCOS: Uma hora e meia para ir, mais uma hora e meia para voltar. Com 34, 36 anos era outra pegada.

CAROLINA: Quantos anos você tem?

MARCOS: Tenho 44. Mas o que eu acho é que foi um momento especial, aquelas condições únicas e singulares.

CAROLINA: A pessoa certa, no lugar certo, com o parceiro certo, com a vontade certa...

MARCOS: Um dia, disse para a Bete: "A gente não licenciou essa parte"; e ela falou: "Essa é minha responsabilidade, vai lá e toca obra, ajuda os caras a construírem". Eu entendi o recado: eu tinha de fazer a obra sair. Se a gente for querer trocar o pneu do carro primeiro, antes de fazer o carro andar, não vamos a lugar nenhum.

CAROLINA: Tem que dirigir o carro com três pneus.

MARCOS: Ela brincava: "Troca o pneu com o carro andando", e a gente vai administrando, porque senão, não faz, não teria feito. Se fosse cumprir todo o rito, teria de convencer a Cetesb, parte das pessoas da Cetesb tem ojeriza do projeto porque não passou por eles para aprovação. Agora, todos os municípios da região metropolitana usam o Cantinho como exemplo.

CAROLINA: Criou-se uma jurisprudência quase, não é? Precisamos disso.

MARCOS: Eu cansei de produzir material para secretário de Habitação de São Bernardo, que dizia: "Olha, me ajuda que eu vou lá na Cetesb, monta umas imagens pra mim". Eu fazia, e todo mundo voltava falando: "O pessoal lá não gosta de vocês". Eu sei que não é nada pessoal, eu entendo.

Melissa Matsunaga, mestre pela FAU-USP em 2015 com o mestrado "Cantinhos do Céu", fez parte da equipe de projeto no escritório de Boldarini Arquitetos Associados que desenvolveu o Projeto do Parque Linear Cantinho do Céu

CAROLINA: Conte um pouco da sua formação e da sua relação com a represa.

MELISSA: Eu me formei em São Carlos, em 2005, e fui trabalhar com o Marcos Boldarini no meio de 2008; nessa época, eu estava trabalhando na prefeitura de Cosmópolis, era concursada e trabalhava vinte horas por semana lá.

CAROLINA: Qual a distância entre Cosmópolis e São Paulo?

MELISSA: Não sei exatamente, mas são duas horas de ônibus. Eu comecei a vir pra São Paulo no segundo semestre de 2008; vinha, ficava quarta e quinta trabalhando no escritório, e depois voltava para Cosmópolis. Nessa época, já pensava em vir para São Paulo de vez. No começo de 2009, o projeto do Cantinho do Céu foi iniciado. Já havia o projeto de urbanismo, mas o do parque ainda não. Acabei entrando no projeto do parque. Depois, com 
a saída de algumas pessoas da equipe, assumi uma das frentes de urbanismo, mas o início do projeto mesmo eu não peguei. Foi aí que conheci a represa e comecei a ir a campo para ver como estava sendo realizada a remoção das casas. Era para ser feita uma complementação da topografia e, depois disso, seria realizado um novo levantamento topográfico planialtimétrico, antes de iniciarmos o projeto executivo do parque. A gente ia para a obra porque algumas casas não saíam, e houve algumas revisões de campo. Foi importante estarmos lá para saber se era necessário remover determinada casa ou não, e para acompanhar as alterações da área disponível para o parque.

CAROLINA: O projeto sofreu adaptações bem consistentes. Vocês tinham um projeto executivo que não era exatamente executivo, porque tiveram que refazê-lo. Você consegue se lembrar de algum exemplo?

MELISSA: O projeto básico da gerenciadora elencava um programa para o parque, atividades de lazer e tal, mas não tinha exatamente um desenho, eram diretrizes. Era mais ou menos assim: "Pode ser que aqui tenha um campo, mas pode ser que aqui não caiba um campo". Então, tínhamos uma ideia do que ia ser, mas só a ida a campo e a definição topográfica iam definir, de fato, o que era possivel, e isso foi feito em cada etapa. Havia um esqueminha mostrando as diversas etapas. Deu pra entender?

CAROLINA: Sim. Pelo que vi no livro da prefeitura, vocês pararam na etapa três, certo?

MELISSA: Não, na verdade eles definiram assim para colocar no livro. O melhor é olhar um dos projetos executivos.
CAROLINA: Entendi. Quantas remoções foram feitas?

MELISSA: Isso eu não sei informar.

CAROLINA: No seu texto, você menciona que algumas casas marcadas para demolição acabaram permanecendo; e outras, que foram danificadas no meio do processo, geraram a situação "demolir ou não demolir". Isso tem um custo associado complexo, certo?

MELISSA: Sim, mas quando eu digo isso, estou fazendo estudo de caso do Cantinho. No livro, eu estou falando só do que aconteceu no Cantinho. Lá não se chegou ao desenvolvimento total do projeto. Em alguns trechos, houve remoção, mas acho que nem chegaram a completar a topografia, porque ainda faltava limpar a área e terminar as remoções que estavam marcadas. Foi nesse contexto que eu fiz as entrevistas com os moradores. Eles estavam angustiados, falando: "Ah, falaram que ia sair, mas quando vai ser?". Aqui no Lago Azul, eu não me lembro de ter tido nenhum problema muito sério; eu lembro que aqui tinha uma área de reassentamento para ser feita na P1, mas era bem onde há um vale; era a condição menos favorável para a implantação de um conjunto habitacional; por isso, o reassentamento não foi feito. Tem que localizar exatamente o lugar de que eu estou falando no texto, não estou falando do geral.

CAROLINA: Tudo bem, mas eu queria focar no parque mesmo, não na urbanização do bairro inteiro. Você estava falando que a sua participação começou no projeto básico do parque e que, durante o processo, o projeto foi se adaptando. 
Você também comentou que havia certa urgência na implantação do parque para evitar que, depois da remoção das casas, as pessoas ocupassem a área novamente. Isso era uma possibilidade real? Você sentia isso no campo?

MELISSA: Sentia isso no escritório na verdade. Valeria a pena você fazer uma entrevista com o Marcos sobre essa questão. Eu era só uma funcionária, uma colaboradora. Essa era minha percepção, mas pela experiência dele em urbanização era muito provável que acontecesse. Ele dizia: "Se houver remoção e não houver nada como proposta alternativa para a área, provavelmente, aparecerão novas ocupações". Acho que a ideia de definir pequenas etapas foi para dar agilidade ao processo. Se a gente tivesse que projetar de tudo de uma vez, ia demorar muito, e ninguém ia ver resultado a curto prazo, porque a remoção tem um tempo, o levantamento planialtimétrico tem outro tempo, a execução e a elaboração têm outro tempo. Como foi um projeto com forte mobilização social, acho que tinha que dar uma resposta rápida. Mas penso que era uma análise muito da experiência do próprio Marcos. Ela achava que não podia demorar muito; novas ocupações inviabilizariam a execução do projeto. Seriam novas famílias a ser contempladas, e isso dá uma desandada, vamos dizer assim.

CAROLINA: Só para entender, esse projeto básico que vocês receberam foi discutido com as pessoas em algum momento? Foram feitas oficinas de discussão? O projeto circulou entre os moradores?

MELISSA: Teve, na verdade, uma interlocução muito forte com a dona Vera, que naquele momento era uma liderança muito efetiva. A gente tinha conexão direta com ela, e propusemos uma reunião para apresentar a proposta a todos os moradores. Foi num sábado de manhã, e pouquíssimas pessoas apareceram. No fim, o canal de interlocução foi sempre intermediado pela Vera. Não foram feitas oficinas, era uma coisa de falar com ela, e ela dizer: "Olha tá acontecendo isso"; ou então: "Ah, tem como fazer um campo de bocha?".

CAROLINA: Eu ia comentar exatamente sobre isso. Queria saber como vocês decidiram planejar um campo de bocha.

MELISSA: Foi uma demanda da Vera. Nem sei se funciona.

CAROLINA: Eles usam para outras atividades, mas tudo bem também.

MELISSA: Sim, é ótimo isso.

CAROLINA: Como profissional, acho que quanto menos específica e mais multifuncional a área, melhor. É complicado pensar "atendo ou não atendo; qual é a melhor maneira de atender". Enfim, são questionamentos da nossa profissão. Eu tenho uma curiosidade sobre a negociação com a Emae. A faixa exclusiva de domínio da Emae é de até 50 metros, certo? Teve uma outorga da Emae para a prefeitura de São Paulo? Foi um comodato? Você tem noção de como funcionou a parte fundiária do parque?

MELISSA: Essa informação eu não tenho; lembro que chegamos a fazer uma reunião, mas o que existia na Emae era um levantamento da área da represa da época de sua constituição, em 1927. Essa constituição mudou, teve assoreamento. A área não batia, mas o documento afirmava que aquela 
área pertencia à Emae. Era uma discussão difícil de levar à frente, sabe? Isso acabou ficando um pouco para trás. Primeiro, entramos com a infraestrutura, e a questão da regularização fundiária ia ficar mais diretamente com a equipe da prefeitura. Eu entendi um pouco assim naquele momento. Agora, como houve mudança da gestão, e também porque, coincidentemente, eu saí, não sei qual foi a finalização. A própria aprovação do projeto estava em trâmite.

CAROLINA: Ah, entendi. Tenho uma entrevista marcada com um funcionário da Emae; talvez ele saiba me dizer como isso foi feito.

MELISSA: Acho que quem pode falar melhor sobre isso é o Marcos mesmo.

CAROLINA: Eu conversei com ele, mas talvez tenha que entrevistá-lo novamente. E tem também a questão da negociação da faixa de 50 metros da borda da represa; em alguns trechos o parque e as casas que foram mantidas estão a menos de 50 metros da linha máxima de alagamento...

MELISSA: Acho que são duas coisas, Carol: uma é a cota de alagamento, que é a 747; outra é a linha dos 50 metros da borda da represa. Não sei agora se são 50 ou 100 metros.

CAROLINA: Acho que na represa são 50 metros.

MELISSA: Isso é da legislação ambiental. Considerando a famigerada faixa de APP, de fato há trechos que não atendem a faixa de 50 metros. Aí é que está, o critério não foi exatamente a legislação, mas a adequação da estrutura. Se era possível realizar a infraestrutura de saneamento em determinada casa, não tinha motivo para removê-la só por conta da legislação. Foi uma criterização que utilizamos exatamente para tentar diminuir o número de remoções. Se fôssemos atender a legislação ambiental, iríamos desconfigurar o bairro.

CAROLINA: É muito interessante a discussão, eu diria quase filosófica, que põe em questão o fato de a represa ser uma lagoa artificial, então, a ideia de natureza intocada não se aplica. Seria importante discutir isso, você não acha?

MELISSA: Sim, mas isso não aconteceu no Cantinho do Céu. Tínhamos que seguir a legislação, e do meu ponto de vista deveríamos ter aprovação desse projeto antes da execução da obra. Naquele momento, a Elisabete França estava à frente da coordenadoria de Habitação. Ela queria muito realizar uma proposta nessa perspectiva. Se a gente ficasse esperando a aprovação, o projeto não ia se realizar nesse tempo; e é preciso lembrar também que havia uma ação civil pública. A prefeitura tinha pressa para resolver, porque isso já estava se arrastando há um tempo. A Bete bancou essa responsabilidade; a gente estava executando, mas tinha alguém que garantia: "Pode fazer que eu seguro a bucha disso aí". Era ela que estava enfrentando os órgãos licenciadores. A atitude dela foi muito importante para as soluções que adotamos lá; fizemos deques que se projetam na água. Isso pode parecer muito simples e tal, mas quando entra a questão legal é tudo muito engessado, muito complicado. Tinha também a questão do ressarcimento das moradias todas, que também contribuiu para a permanência de algumas casas, mas tem sempre as duas coisas.

CAROLINA: Acho que eu, enquanto pesquisadora, não posso tomar partido, mas percebi que as remoções foram muito traumáticas. Sei que algumas 
pessoas falavam "A gente não vai usar o parque". Isso é uma ferida no meu trabalho, considerando o objetivo que ele tem.

MELISSA: Sim, com certeza.

CAROLINA: Mas eu entraria com uma ressalva no ponto de vista do trauma das remoções. Acho que é muito importante, sim, colocar que foi uma discussão política que passou por cima das instâncias. Mas eu entendo que a maior dificuldade para alterar esse cenário da Billings é promover a articulação entre município, secretaria do Meio Ambiente, Emae, moradores. Acho que no caso do parque houve articulação, embora a Elisabete tenha assumido a responsabilidade, houve articulação, mesmo que vertical, mesmo que ela tenha tomado esse lugar de bancar tudo sozinha.

MELISSA: Acho que valeria até a pena você conversar com ela, porque tem até o próprio trabalho dela de doutorado sobre urbanização, sobre a política da gestão dela. Ela fez pelo Mackenzie. E ela tem uma superexperiência como gestora. Ela é uma pessoa que puxa a responsabilidade para si, é uma pessoa que vai enfrentar... Enfim, estou falando demais.

CAROLINA: Vou conversar com ela. Ontem, ouvi um comentário que eu achei um pouco estranho, mas que não deixa de ser um modo de ver a situação. A hipótese é que o parque só saiu por conta de uma articulação da dona Vera com um político chamado Milton Leite. Você sabe alguma coisa sobre isso? Isso era assunto na época da implantação do parque?

MELISSA: A gente sabia que a Vera tinha esse vínculo, sempre soubemos. Não somos ingênuos de achar que ela era uma liderança apartidária.

CAROLINA: Não era uma liderança natural?

MELISSA: Não. No meu trabalho de mestrado, eu pontuo um pouco isso também. Como acabou acontecendo uma re-significação dessa liderança, e como a Vera sofreu depois da implantação do parque. De fato, se pegarmos todo o processo histórico que motivou a ação, vemos várias gestões tentando solucionar a questão da represa, bem ou mal, de alguma maneira. Há todo um encaminhamento processual no fórum, e eu fui ler todos os volumes para saber quais tinham sido os passos dados desde a instauração da ação civil pública. Sabíamos das relações políticas da Vera; o que eu não sei é em que medida isso pôde ser cooptado só para um partido, já que representou uma melhoria para todos. Não sei se ela escolhia as reivindicações só de alguns, isso eu não sei. Nossa atitude sempre foi: "A liderança que a gente tem é essa, a situação é essa, a condição é essa; ou é com ela ou é sem ninguém". A Vera sempre nos falou da vinculação dela com a política. Não tenho certeza se isso foi ou não prejudicial. Temos que ter nossos aliados. O fato de a Vera ser do mesmo partido da gestão que tocou o projeto, pode ter deixado outras lideranças do Cantinho do Céu, vinculadas a partidos diferentes, insatisfeitas. Talvez tenha sido isso, insatisfação porque a liderança no bairro era do mesmo partido da gestão. Acho que isso é inevitável, todo mundo tem suas vinculações, suas crenças. A Vera ficou triste porque ficou muito claro qual tinha sido o papel dela ali. No fim, ela foi meio deixada de lado; alguém que era tão importante durante um momento... A gente sempre romantiza a questão da liderança: "Eu faço isso por convicção, por acreditar e tal, dedico a minha vida, parte do meu tempo para 
isso". De fato, ela dedicava parte da vida dela, mas era um trabalho também, ela era paga. Essa questão política não é muito clara para mim, mas, eu não sei, não acho que tenha sido um problema; tínhamos que trabalhar com quem estava em campo com a gente, os aliados são esses e a gente vê o que dá para fazer. Teve uma demanda que chegou, não sei se pelo Milton Leite, para fazer um campo flutuante na represa.

\section{CAROLINA: Sério?}

MELISSA: Foi uma demanda que chegou; era quase que um "boatinho" dentro do processo de projeto. Não fizemos, claro, mas daria um campo em tamanho oficial...

CAROLINA: Era o orçamento do parque inteiro, não é?

MELISSA: Flutuante, um estádio flutuante! Ele queria um campo oficial de qualquer maneira, e nós dizíamos: "Não, a gente está trabalhando com faixas mínimas, tem coisas que não dá para fazer, não é assim"; e ele: "Ah, eu prometi".

CAROLINA: O campo de futebol existe, certo? Tirei uma foto quando visitei o mirante. Dá pra ver o campo do outro lado da represa, na margem do Céu Navegantes. E tem o campo perto da entrada do Residencial dos Lagos.

MELISSA: Quando inauguramos a P1, a Vera chegou com uma solicitação de cercar o campo de grama sintética para ter uma chave; eles queriam, e ela queria, enfim, queriam poder dizer: "Ah, eu que mando". Nós respondemos: "Não, a gente não fez esse projeto para ser privatizado por algum grupo, se houver esse exercício de domínio, que ele se dê ali na conversa, no diálogo".

CAROLINA: Na disputa pelo lugar público, certo?

MELISSA: Exatamente, não é com uma chave que a gente vai ceder o domínio para alguém. Não sei como está hoje; se existe isso: "Ah, o campo é dessa galerinha, a pista de skate é dessa outra". Inicialmente, há os grupos aos quais o espaço é destinado, mas pode haver um grupo de futebol que não usa o campo, então, não sei.

CAROLINA: Não me detive nisso, mas percebi, durante as visitas que fiz, que a utilização do campo de futebol é bem dinâmica: às vezes, tem adulto; às vezes tem criança. Nunca vi time uniformizado jogando, o que seria um indicativo de domínio. Mas não segui de perto nenhum grupo específico. Até pensei nisso, mas daí perderia a chance de olhar para o parque e para as pessoas. Para mim, o mais legal é atualizar o parque como ele é usado agora, entender quais são os conflitos, quais são os grupos que usam determinado espaço e como usam. Me chamaram a atenção as relações que foram estabelecidas no festival que a Red Bull patrocinou. Uma parte do festival foi programada para acontecer no Centro Cultural Grajaú, e a outra parte na pista de skate do parque linear, mas a pista estava numa situação meio precária. O patrocinador do festival cedeu o material, e os moradores fizeram a reforma. Mesmo com todas as questões que a gente pode colocar acerca de uma grande marca utilizar o espaço público, captar imagens e se apropriar delas, os moradores estavam contentes. Foi a primeira vez que uma grande marca esteve presente na pista de skate, e desse ponto de vista simbólico, de reconhecimento do lugar como um 
lugar importante na cidade, foi superlegal. Então, temos que entender que os significados atribuídos por quem olha de fora são totalmente diferentes dos significados de quem está dentro da comunidade.

MELISSA: O nosso preconceito... Estamos sempre pensando: "Ah, é privatização, a empresa está querendo ter lucro em cima de uma coisa que é pública, utilizar as imagens de uma associação ou de um coletivo em benefício próprio". De fato, somos contrários a isso, mas diria que é um preconceito, porque barramos qualquer relação mais fortalecida de diálogo com grupos privados. Se olharmos a cidade formal, a privatização do espaço público está dada sempre e a todo momento. Acho que nós, arquitetos, temos preconceito, condenamos essa ideia. Lembro que me incomodava até com a ideia de terceirização dentro do parque. Esperava-se que as pessoas cuidassem do parque, mas ninguém vai lá recolher o lixo do Ibirapuera, existe um serviço contratado para a limpeza. Aqui, os moradores têm que fazer isso e, poxa, qual é o peso e qual é a medida? Como eles se veem dentro do sistema. No fim, não podemos esquecer que o objetivo principal é a inclusão.

CAROLINA: Justamente.

MELISSA: Acho que a palavra "inclusão" está em desuso, ouço falar pouco, mas quando a gente vai trabalhar com habitação tem que ter um olhar para a questão social. Infelizmente, a inclusão é inerente ao processo capitalista de produção. Então, quando uma grande marca patrocina um evento no Cantinho do Céu, acho que comunidade se sente incluída de fato: "É, a gente está quase lá".

CAROLINA: Não dá pra desconsiderar o fato de que todos fazemos parte do mesmo sistema; não há como exigir um comportamento completamente diferente; o sistema está no horizonte de inclusão. Também percebi no parque que o campo de futebol e a pista de skate têm presença marcadamente masculina.

MELISSA: Ah, sim.

CAROLINA: É questão da antropologia, mas acho a discussão muito interessante: o espaço público é majoritariamente ocupado por homens. No parque, ainda se vê criança, menina mais jovem circulando de bicicleta e tal, mas na área de esportes, naquela areazinha do campo de futebol e da pista de skate, a predominância absoluta é de meninos. Acho que na periferia, mais do que nos centros metropolitanos, o papel da mulher ainda está centrado no privado; o público é um papel masculino.

MELISSA: Nossa, perfeito, isso mesmo! Mas há os coletivos feministas.

CAROLINA: Conheci uma cooperativa de catadoras, mas acho que seria bem interessante eu conversar com os coletivos feministas.

MELISSA: Acho que sim; essa ideia que você colocou de a mulher ainda permanecer no âmbito do espaço privado pode significar também que as moradoras não tiveram proeminência na articulação das demandas.

CAROLINA: Que elas não estão presentes no espaço físico do parque, eu posso afirmar por experiência. Em relação à articulação, eu teria que pesquisar para ter certeza. Vou entrevistar o Ferruge de novo esta semana; vou falar com ele sobre isso também. 
MELISSA: Isso; ele deve ter bastante informação.

CAROLINA: Outra coisa que me chamou a atenção foi aquele painel colorido; acho que foi um grafiteiro de Santos que fez, não foi?

MELISSA: Na verdade, ele é um artista plástico, Maurício Adinolfi. Ele foi contratado para fazer a identidade visual do parque. A gente conversava bastante em relação às cores e tal: "Ah, aqui vai ser um espaço de reunião; aqui é uma área aberta; aqui uma arquibancada". Enfim, eu passava para ele mais ou menos a definição dos espaços, e ele fazia a proposta. A ideia era criar uma interface entre o que era área do parque e o que era área das casas, por isso a intervenção se deu nas empenas laterais das casas, para marcar mesmo: "Aqui começa o parque". Uma proposta meio que de significação mesmo; uma pintura que significava "a área do parque começa a partir daqui".

CAROLINA: Com tantos coletivos de grafite, isso claramente deixou de existir.

MELISSA: Foi uma das primeiras modificações na apropriação do parque. Pessoalmente, acho que faz parte, mas entendo o ponto de vista do arquiteto, da arquitetura moderna em relação às artes. Tinha até uma escultura prevista para ser colocada no parque.

CAROLINA: Olha só...

MELISSA: Não teve recurso para isso, a construtora disse: "Não vou gastar isso tudo para colocar uma escultura". Acho que era um desejo do Marcos e da Bete, ter um espaço arquitetônico vinculado às artes, mas não necessariamente às artes de rua; trazer outros tipos de apreensão do espaço. Mas o que acabou virando escultura foi a estrutura do cinema, ficou um arco lá; é a estrutura da tela, mas como não está sendo usada...

CAROLINA: Acaba tendo esse papel de...

MELISSA: Marco, é um referencial.

CAROLINA: Se você fosse entrevistar algum morador de novo, quem você escolheria?

MELISSA: Olha, tinha uma moradora que era uma das mais antigas, a dona Lurdes. Ela morava bem na esquina da parte $1 \mathrm{com}$ a parte 2 , bem perto da estação elevatória. Como ela vivenciou todo o processo de mudança, talvez tenha novas opiniões. Quando eu a entrevistei ela disse que o bairo tinha melhorado muito, apesar de reclamar um pouco do barulho. Talvez escolhesse alguém jovem também. Para o seu trabalho, acho que a dona Lurdes não interessa, ela não usa muito o parque. Seria bom alguém da parte que está sendo finalizada agora. Há os moradores antigos também. Deixa eu pensar... Na verdade, eu não cheguei a bater nas casas...

CAROLINA: Eu entendo, foi acontecendo. Acho que é mais interessante assim, um conhece o outr, e vai se formando uma rede.

MELISSA: Talvez uma pessoa interessante de conversar seja a dona dessa construção que fica bem na ponta; ela aumentou o número de pavimentos...

CAROLINA: Ah, eu vou falar com ela.

MELISSA: É um hotel ali. 
CAROLINA: É um negócio surreal. Tem quatro pavimentos. Eu marquei de entrevistar a dona esta semana. Ela tem um barzinho numa rua que dá para o parque e tem essa casa monumental. Depois eu conto para você o que aquilo é exatamente. Queria perguntar sobre aquele monte de planta que se junta nas margens e deixa um cheiro tão ruim perto da represa; não é cheiro de esgoto.

MELISSA: É o aguapé. Ele se forma por conta da carga orgânica; daí, quando é período de pouca chuva ou de muita chuva, eu nunca sei, o oxigênio da água diminui e fica aquele verde.

CAROLINA: Vocês limparam isso tudo, não foi? Porque nas fotos do projeto a margem parece tão limpinha.

MELISSA: Isso a gente nunca mexeu, o aguapé se desfaz sozinho. Não sei se a Emae faz alguma coisa, mas nós não mexemos. O que nós fizemos foi plantar espécies nativas de Mata Atlântica.

CAROLINA: Curiosamente, nas fotos do caderno da prefeitura os aguapés não aparecem.

MELISSA: Isso é interessante, não foi o foco do meu trabalho obviamente, mas eu também tive essa percepção quando fui estudar a questão da poluição da represa. Tem um discurso montado de que as famílias dos assentamentos poluem a represa; na verdade, o que acontece é que toda a carga poluída do Pinheiros vai para a Billings.

CAROLINA: Um funcionário da Sabesp me disse que, às vezes, o volume que se bombeia é quase $\nabla$ do volume da represa; ou seja, por um período $X$ de tempo, $₫$ da água da represa vem da cidade de São Paulo.
MELISSA: E existe um discurso que criminaliza a população que mora na margem da represa. Sabemos que o sistema Billings, implantado desde o início do século passado, alterou a bacia hidrográfica, porque o fluxo do rio foi invertido. Então, por mais que se invista na infraestrutura dos bairros aqui, temos que lidar com o esgoto da metrópole inteira. Se fosse só a carga poluente das casas, para o volume de água da represa, não que seja insignificante, mas é muito menor do que essa carga que chega diariamente da cidade. Dizer que é preciso remover as pessoas daqui porque elas estão em área de mananciais é um discurso montado. Como você mesma disse, é uma represa artificial; que natureza é essa que estamos a preservar? Outra questão é o fato de não ser permitido ter estação de tratamento de esgoto na área de mananciais. Então, vão se criando essas unidades de estação elevatória para bombear a água e tratar lá em Barueri, a não sei quantos quilômetros de distância.

CAROLINA: Vocês receberam desenho de toda essa infraestrutura e foram compatibilizando com o projeto?

MELISSA: Não teve muito uma compatibilização. Eu percebi que a Sabesp faz a implantação das unidades de estação elevatória de esgoto primeiro e vai verificar a situação em campo depois. Deveria ter uma compatibilização dessas áreas de remoção para as unidades das estações elevatórias, mas a estação já estava implantada no Lago Azul. Tivemos que analisar se casa estava abaixo ou acima da cota para, então, levar para a estação elevatória.

CAROLINA: Acho que essa é a grande questão da represa, muitas pessoas responsáveis e não respon- 
sáveis ao mesmo tempo. A ideia do comitê de gestão da bacia é muito bem-vinda e razoável, mas ele teria de ser atuante, com a presença dos municípios e com poder executivo, além de consultivo. Atualmente, as pessoas não participam, vários municípios nem mandam representantes. As grandes empresas consultam o comitê só quando "dá na telha", então, nem consultivo ele é. Acho que é preciso fortalecer esses comitês para que se consiga ter uma visão global da bacia, da contribuição do Tietê etc. Para encerrar, e para não restar nenhuma dúvida sobre a setorização, eu quero perguntar: a ideia é que o parque tenha continuidade nas áreas em que foi feita a urbanização, Lago Azul, Jardim das Gaivotas e Cantinho do Céu, certo?

\section{MELISSA: ISSO.}

CAROLINA: Teoricamente o parque vai seguir pela orla toda.

MELISSA: Sim, é exatamente isso. Mas nesse primeiro momento finalizou, mudou a gestão. Mas tinha também uma questão de frente de obra, eu lembro que não é uma coisa linear como foi aqui. Então, abriu-se um buraco que foi de remoção, primeiro lá em cima, depois um pouco para baixo, depois um pouco para o lado...

CAROLINA: Não teve essa continuidade sequencial na orla.

MELISSA: A ideia é preencher tudo, mas essa definição depende um pouco do diálogo com as famílias; há trechos que são mais resistentes. No trecho que fica ao norte, há várias casas, e é um dos trechos mais difíceis de diálogo. Estava marcada uma grande área de remoção ali; é uma das mais difíceis de entrar, exatamente pelo tamanho.

CAROLINA: Tem algum outro motivo para essa dificuldade, além do grande número de pessoas?

MELISSA: Acho que tinha também uma influência local do grupo de drogas. É mais ou menos assim: "Vamos deixar os caras lá enquanto fazemos outros trechos". Mas ali há também a questão do assoreamento; a área está desbarrancando, formando umas falésias.

CAROLINA: Sim, parece que é um paredão que está desbarrancando.

MELISSA: É preciso pensar isso ao longo do tempo, porque a represa não vai parar de se movimentar, então esse local também pode ser definido como uma área de risco, e esse ser o indicativo de remoção. Mas tem que ir para campo para avaliar: "Será que é isso mesmo; será que dá para manter; como está hoje situação, porque isso foi em um determinado momento".

CAROLINA: Sim, o domínio do território se modifica, é superdinâmico...

Elisabete França, arquiteta, foi secretaria da Habitação entre 2010-2012 e Habitação e entre 2005 e 2012 foi Superintendente de Habitação da Secretaria de Habitação da Cidade de São Paulo, período em que o projeto do Parque Linear Cantinho do Céu se desenvolveu

ELISABETE: Você foi ao parque linear recentemente? 
CAROLINA: Fui quinta-feira passada.

ELISABETE: Está horrível. Bem triste.

CAROLINA: Mas ele tem muito uso.

ELISABETE: Sim, tanto é que conseguimos transformá-lo em parque municipal, mas infelizmente não cuidam. Tinha que ser cuidado como o Ibirapuera.

CAROLINA: É verdade. Mas o parque não me pareceu tão descuidado. Estão reformando a ponte, o mato está bem aparado; e é preciso considerar que o lugar é intensamente usado. Há pouco tempo, a Red Bull levou para lá o Amaphiko, um festival que já foi feito na África do Sul algumas vezes e cujo objetivo é empoderar agentes sociais locais. Como parte do festival, a Red Bull patrocinou a recuperação da pista de skate.

ELISABETE: Mas é madeira, está mal cuidado.

CAROLINA: É, a madeira sim. Inclusive, tenho uma pergunta sobre as escolhas do projeto. Mas, antes, eu gostaria que você falasse sobre sua formação.

ELISABETE: Eu sou arquiteta; me formei em 1980, em Curitiba. Fiz mestrado na FAU-USP e doutorado no Mackenzie. Sempre gostei de desenho urbano, porque estudei em Curitiba, e lá tem muito desenho urbano. O urbanismo lá é superforte na escola. Eu nunca gostei de planejamento urbano, muito menos do plano diretor, sou amaldiçoada em São Paulo por isso. Mas eu estudei todos os planos até... Nem lembro qual foi o último, acho que foi o da Marta Suplicy. O plano diretor nunca rebate no território. Não resulta em desenvolvimento.
CAROLINA: Quando começa sua relação com os mananciaia?

ELISABETE: Eu comecei a trabalhar na prefeitura em 1983. Foram dez anos perdendo tempo com plano diretor. Em 1993, mudei para a SeHab, e tinha lá um programa para o qual ninguém dava muita importância: o Programa Guarapiranga. Era junto ao governo de estado, superintegrado a várias secretarias, muito legal. Coordenei esse programa por oito anos. Tinha um aporte grande de recursos do Banco Mundial, e ideias avançadíssimas. Naquela época, não tínhamos know-how de urbanização, então, trabalhamos paralelamente ao favela-bairro no Rio, que tinha aportes do Banco Interamericano. Era um momento em que os bancos financiavam muito esse tipo de intervenção nas cidades, a urbanização de bairros precários. Havia um grupo muito visionário, principalmente, no Banco Mundial.

CAROLINA: Foi uma confluência favorável de um grupo na prefeitura, no estado, com recurso....

ELISABETE: Pra mim, o favela-bairro é o programa mais notório nessa área. Você já estudou sobre ele?

CAROLINA: Recentemente, houve apresentação de várias iniciativas no Mackenzie. Eu assisti, mas não tenho muito conhecimento.

ELISABETE: Foi muito revolucionário. Países, cidades, começaram a copiar. É engraçado, porque se você vai a Medellín hoje, ver o que eles fizeram, percebe que foi exatamente o que fazíamos no Rio nos anos 1990. No governo da Erundina, esse tipo de projeto não era prioridade; a prioridade era mutirão. Mas a Laura fez alguma coisa, uma favela aqui, outra ali. 
CAROLINA: A Laura Bueno?

ELISABETE: A Laura Bueno. O doutorado dela foi sobre isso. Eu dava aula na Braz Cubas e reuni vários alunos no projeto da Guarapiranga. Não era urbanização stricto sensu, era saneamento básico. Enfim, fomos criando know-how, e uma equipe foi se formando. Oito anos depois, veio o Programa Mananciais, porque o programa começou a abranger a Billings também. Já tínhamos um super know-how; publicamos um livro na época do Guarapiranga. O favela-bairro foi superpremiado; algumas cidades iniciaram programas semelhantes. Houve uma conferência em Istambul, em 1996, que praticamente, só tratou de urbanização de favela. Enfim, o Brasil tinha tudo para dar certo na área urbana. Eu saí da prefeitura e só voltei na gestão do Serra, mas aí não tinha mais a presença do Banco Mundial.

CAROLINA: Por que a questão é sempre a falta de recursos?

ELISABETE: Não era questão de recursos, não era esse o problema. O problema é ter um parceiro que monitore, cobre. O Banco Mundial estava constantemente cobrando a presença de uma equipe social, a presença de programas de capacitação da comunidade, a geração de emprego, porque favela é um negócio complexo, não é só fazer obra. Tem que capacitar pessoas, formar lideranças, prepará-las para ajudar a administrar os espaços. Exigências que os bancos fazem quando emprestam dinheiro. Muitos colegas seus da FAU-USP adoram escrever "o imperialismo, não sei o quê..." É aprendizado; não tem nada a ver com imperialismo. Em 2002, eu trabalhei em uma usina hidrelétrica, e tinha que desenhar cada milímetro que a água cobriria se houvesse um terremoto, se um meteorito caísse, porque os investimentos eram do BID e do Banco Mundial. Ai, em Brumadinho, eles põem o refeitório embaixo da barragem. É um crime isso. Um crime. Os bancos acumulam experiência, faz parte da expertise deles analisar riscos.

CAROLINA: O Cantinho do Céu é resultado da experiência adquirida na Guarapiranga?

ELISABETE: Em 2005, quando eu voltei para a prefeitura, eu tinha passado quatro anos trabalhando em projetos com o Banco Mundial. No início do plano de habitação, estabelecemos uma unidade territorial de projeto, que era a sub-bacia, isso tínhamos aprendido na Guarapiranga. Todo o plano de habitação foi em função das unidades territoriais dessas sub-bacias. Então, os arquitetos projetavam dentro dessa lógica. Enfim, o Cantinho do Céu é resultado de vários períodos de aprendizado. Todo o diagnóstico foi feito em cima de contagem, de entender a realidade do local.

CAROLINA: O que eu entendi das conversas que tive com o Marcos e com a Melissa, é que a ação civil garantiu que o projeto saísse no tempo estimado; era preciso dar uma resposta rápida.

ELISABETE: Sim, porque a ação mandava tirar dez mil famílias dali do dia pra a noite.

CAROLINA: Ideia de quem não é técnico, de quem não imagina o que significa desalojar dez mil pessoas. O que se produziria de entulho e de lixo... Isso só para começar.

ELISABETE: Hoje não fariam uma coisa dessas, mas na época o Ministério Público era superatrasado. 
Isso era uma briga constante; eles entendiam que a solução era tirar todo mundo, e nós argumentávamos que a solução era o saneamento.

CAROLINA: Ainda mais porque o esgoto não é tratado na bacia.

ELISABETE: Não pode. Tem que coletar, mandar para os emissários da Sabesp e levar para Barueri. É idiota, porque poderia fazer lá.

CAROLINA: Ao mesmo tempo, não tem espaço, porque para tratar em um nível que a represa possa receber, precisa de grandes áreas.

ELISABETE: É, mas o saneamento no Brasil, vamos combinar...

CAROLINA: Eu sinto uma certa resistência.

ELISABETE: É por isso que há 100 milhões de pessoas sem tratamento de esgoto no país. Podia-se pensar em soluções menores, mas ficam aquelas estações, quebra, entope, não vai esgoto.

CAROLINA: Volta e meia as bombas dão problema.

ELISABETE: Sabe que eu saí da área porque fiquei muito deprimida? O Brasil funciona como se não tivesse favela. Nenhum governante fala sobre esse assunto. Na Baixada Santista, o censo 2010 contou 60 mil moradores em favelas. Na verdade, são 160 mil pessoas. Na região metropolitana de São Paulo, acontece a mesma coisa. Não é pauta de governo. Não gostamos desse problema, não é?

CAROLINA: Nossa, nem vamos falar nesse assunto, senão acabo mudando o foco da minha pesquisa.
Como ficou a questão fundiária no Cantinho do Céu? É uma das questões mais complexas, não é? E me parece que não está resolvida até hoje.

ELISABETE: Não está e não será resolvida tão rapidamente, porque uma parte da área é particular; então, teria que falar com o dono.

CAROLINA: Uma parte onde foi implantado o parque?

ELISABETE: O parque está na área da Emae. O problema é a urbanização, porque existe uma parte que é pública, e uma parte que é privada. O dono queria recuperar a área; eu fui com ele lá para passear, e ele disse: "Nossa, que legal; acho eu não vou recuperar nunca". Eu respondi: "Não". Existem instrumentos para o morador pagar o proprietário, e nós íamos começar a trabalhar nisso. Mas depois que veio a nova gestão, parou tudo. Não sei se vão retomar, mas é um processo demorado. E, enquanto isso não se resolver, os moradores não podem ter registro da propriedade. Não que eles parem de investir, eles investem, mas sempre fica uma dúvida.

CAROLINA: E há casos em que as casas foram demolidas e não houve a continuação do projeto.

ELISABETE: Mas está andando agora, não está?

CAROLINA: Sim, Retomaram agora.

ELISABETE: Parou por uns seis anos?

CAROLINA: Então, seis anos na periferia é uma eternidade. É uma nova geração, uma casa nova que apareceu ali... 
ELISABETE: A gestão que veio depois da nossa não gostava de urbanização.

CAROLINA: Acho que para resolver efetivamente toda a borda da represa vão uns trinta anos.

ELISABETE: Isso se a urbanização estiver na pauta dos governos. Depois, ninguém entende a violência urbana... Mas a notícia que você me trouxe sobre a realização de eventos no parque...

CAROLINA: O parque é muito legal, Bete. Eu fiquei muito bem impressionada. Há problemas de manutenção como em todos os lugares de São Paulo. Queria até fazer um pequeno recorte aqui: talvez a madeira usada no deque pudesse ter uma espessura maior, pelo menos nas partes que tomam mais sol. No pier, me pergunto se espaçamento de apoio não esta...

ELISABETE: O Boldarini pesquisou muito para projetar o pier. De qualquer maneira, era o primeiro que estávamos fazendo. Mas ele fez muita pesquisa. Você já falou com ele, o Boldarini?

CAROLINA: Falei, mas acho que vou voltar lá. Imagino que o uso da madeira seja porque, além de ser superlegal, é um material permeável, não? Na Prainha, meu segundo caso de estudo, o deque avança na área de cota alagável, e como é área... ELISABETE: Área protegida, certo?

CAROLINA: Sim, sim. E ai entra uma discussão que eu acho muito interessante: ficamos lutando por causa de uma faixa de areia de 50 metros de uma represa que é artificial, não se trata de proteger uma natureza intocada, certo?
ELISABETE: Essa discussão é muito difícil. Eu aprendi que, como nós somos muito destruidores do meio ambiente, é bom que haja exigências. Num país que destrói tudo, acho bom que se protejam as margens da represa. Não é ruim. Veja o Parque dos Búfalos... Um escândalo aquilo.

CAROLINA: As fotos aéreas são chocantes.

ELISABETE: Eu fui lá visitar, é deprimente. O projeto é nojento, acabou com todas as nascentes.

CAROLINA: Eu acho que é o pior modelo de urbanização.

ELISABETE: Era só fraude. O Ministério Público foi prendendo todo mundo, porque eles mentiam no cadastramento. Tanto é que são quatro unidades e só conseguiram mudar e comprovar mil famílias até agora.

CAROLINA: Vamos voltar para o parque que é mais legal. Uma pergunta: na fala do Marcos e da Melissa, você aparece como a pessoa que bancou a história de fazer o parque. Como você se vê nesse processo?

ELISABETE: O Ministério Público queria que tirasse todo mundo. Obviamente, não era possível. Então, fomos negociando com eles. O Ricardo Sampaio, que era coordenador do Mananciais, tinha uma superpaciência para negociar com o MP, mostrar que o projeto era importante, que não dava para tirar todo mundo. Acho que era mostrar que, sim, é possível fazer coisas legais e não destruir o meio ambiente. A ideia era essa.

CAROLINA: Você não acha que, tudo bem, o papel do Ministério Público é inquestionável, mas não seria 
importante que eles tivessem alguma formação ou um olhar para o urbanismo?

ELISABETE: Mas o Ministério Público não sabe nem onde ficam os lugares. Eles recebem uma denúncia e...

CAROLINA: Vão dando seguimento.

ELISABETE: O Ricardo foi com eles até lá. Eles nunca tinham ido, não conhecem a realidade. Eles não têm a menor ideia; são advogados, juristas.

CAROLINA: Sim, mas você também é só arquiteta. No entanto...

ELISABETE: Uma vez, recebemos uma ação para tirar mil famílias do Cingapura Zaki Narchi, porque estava vazando gás. Em dois dias.

CAROLINA: Falta base concreta para as decisões do MP.

ELISABETE: Pois é, eles recebem as denúncias e determinam: "Tira todo mundo". Foi aí que o Ricardo entrou. Ele tinha um superambientalista na equipe dele, o Duron, um engenheiro ambientalista que era do Ministério Público.

CAROLINA: O melhor de tudo é que deu certo. O parque linear é um modelo.

ELISABETE: Uma das coisas mais legais de lá é a questão da mobilidade. Nem se falava sobre isso ainda, e a Mônica Dolce, que era da gerenciadora, foi supercuidadosa com isso, exigiu todos os padrões de mobilidade.
CAROLINA: Eu me emocionei quando vi uma família passeando com uma menina, provavelmente, com paralisia cerebral. Desceram para o parque e ficaram a tarde inteira. Aquela criança teria ficado o dia inteiro em casa se o parque não existisse.

\section{ELISABETE: Todas as ruas têm acessibilidade.}

CAROLINA: Eu ouvi de um morador: "Isso aqui era lugar nenhum, agora aqui é um lugar". Eles fazem parte da sociedade. Não são mais o "não-lugar". Eu acho isso incrivel.

ELISABETE: É mesmo. Quando inauguramos, os bombeiros ligavam para reclamar que no fim de semana tinha 2 mil pessoas nadando, e eles não tinham estrutura. Eu falava: "Cria a estrutura, ué".

CAROLINA: Isso é uma questão superséria, inclusive. Precisaria ter um salva-vidas lá. Morreu um menino afogado há pouquíssimo tempo.

ELISABETE: Na época, tinha salva-vidas. Não tem mais? Depois que saiu no jornal a historia da cobra que comia gente...

CAROLINA: Da cobra eu não estou sabendo.

ELISABETE: Era uma cobra enorme que morava na represa e comia criança...

CAROLINA: Eu vejo umas cobrinhas que as garças gostam de comer, mas cobra gigante eu não vi nem ouvi história.

ELISABETE: A dona Vera deve lembrar... Não sei se ela está lá ainda. 
CAROLINA: Ela está lá e tem uma relação meio conflituosa com o parque. Ela queria muito ter sido a gestora e não aconteceu. Então, ela vive implicando com tudo.

\section{ELISABETE: Ela queria ser gestora oficial?}

CAROLINA: ISso, com indicação da prefeitura e contrato. O gestor agora é o Ferruge. No dia em que o conheci, ele tinha ido à casa dela. Ele me disse: "Fui tomar um cafezinho com ela pra ver se apaziguo a moça".

ELISABETE: Ela se achava meio a dona de tudo. Ela está bem velhinha já, não está?

CAROLINA: Sim. Eu acompanhei muito o trabalho do Ferruge. Ele conhece todo mundo, é uma pessoa jovem, o que eu acho que é muito importante. Tem que ter assunto no parque, sabe? O festival que a Red Bul promoveu na pista de skate foi legal porque a galera estava toda lá e se reconhecia naquele lugar.

ELISABETE: É, tem isso. A dona Vera podia ter um cargo de honra num comitê, não é? Ela não tem mais pique para entender a juventude que está lá.

CAROLINA: Talvez, ela pudesse ser uma gestora da terceira idade... Eu brinquei com o Ferruge: "Fala para ela organizar caminhadas pela manhã. Tentar aproximar as pessoas".

ELISABETE: Exercícios para a terceira idade é bom que sejam de manhã. Tinha tai chi chuan de manhã.

CAROLINA: O parque tem seus horários. De manhã, são os senhores eas senhoras; no intervalo da escola, tem uma criançada que cabula aula e vai para o parque; à tarde, vai o pessoal que sai da escola; e a noite é a vez dos que chegam do trabalho. Tem uso o dia inteiro.

\section{ELISABETE: Muito bom.}

CAROLINA: São várias questões a resolver no parque, por exemplo, eles precisam repor os guarda-corpos; foram todos arrancados.

ELISABETE: Mas o parque não tem dinheiro?

CAROLINA: Olha...

ELISABETE: É da prefeitura, eu sei...

CAROLINA: Como é que se libera o dinheiro. Isso é até uma questão para minha pesquisa.

ELISABETE: Cada parte tem uma verba, que é baixa, claro!

CAROLINA: Acho que eles deram preferência para a ponte e para a limpeza. A obra da ponte foi grande; eles refizeram tudo. Acho que a próxima fase são os guarda-corpos. Bom, deixa eu ver se esqueci de perguntar alguma coisa... Como você diria que sua relação com a represa Billings começou?

ELISABETE: Pela Guarapiranga. Como foi preciso começar a captar água na Billings, começamos a preservá-la também. Na crise da água, a Sabesp criou um captador que tirava água da Billings e levava para a Guarapiranga.

CAROLINA: É o Taquaquecetuba, um braço mais distante. 
ELISABETE: No Programa Billings, fizemos todos os projetos que deviam ser contratados. Era a gestão Pitta, 1998, 1999. Fizemos termo de referência para quatro escritórios, um foi para o Cantinho do Céu.

CAROLINA: Tem alguém na SeHab que poderia...

ELISABETE: Deve ter em processo, porque foi contratado. Eu tenho impressão de que talvez no meu doutorado tenha alguma coisa sobre isso. Eu lembro que saí atrás disso, deve ter algo escrito lá. Acho que ainda não tinha o Ministério Público envolvido. Se não me falha a memória, o Marcos Carrilho foi o arquiteto que fez o estudo para o Cantinho do Céu.

CAROLINA: O Boldarini comentou que você sempre trabalha com pessoas com experiência em desenho urbano.

ELISABETE: Pois é, mas sempre me criticam porque eu chamo arquitetos para fazer projetos de arquitetura. No Renova São Paulo, em 2010, 2011, contratamos alguns arquitetos com projeto executivo. Eram contratos muito bons, de altíssimo valor. $\mathrm{Na}$ segunda semana de contrato, me mandaram uma carta dizendo que não iam fazer os complementares, que aquilo não era atribuição de arquiteto. Eu perguntei: "Vocês estão doidos?". Não é todo mundo que sabe fazer, que faz bem. Na Guarapiranga, trabalhamos com uma pequena equipe de arquitetos, que nem eram arquitetos, eram estagiários. E fomos formando esse corpinho de projetos. O Marcos, por exemplo, foi desenvolvendo o currículo dele com isso, ninguém faz urbanização de favela como ele. Pode chamar quem quiser. Ele tem menor custo, maior capacidade, é impressionante.

CAROLINA: Eu vi o projeto dele para o Areião, é incrivel.

ELISABETE: E sabe que a Tássia, a secretária de Habitação de São Bernardo, chamou o Marcos porque os moradores disseram pra ela: "Tem um bairro lá na frente superbonito"; e ela me ligou perguntado quem estava fazendo. A população está atenta.

Marco Aurélio Garcia, Arquiteto e coordenador do projeto de revitalização da Prainha do Riacho Grande no âmbito da Urbaniza Engenharia, vencedora da licitação

CAROLINA: Vou me apresentar para você. Sou arquiteta de formação e estou fazendo um mestrado em paisagem e ambiente. É uma área de concentração da pós-graduação da FAU-USP.

MARCO AURÉLIO: A sua graduação é de onde?

CAROLINA: É da FAU/USP também. Meu orientadoré o Eugênio, ele tem alguns projetos de espaços livres e experiência de parques públicos. Com esse viés dos espaços públicos e do lazer, decidimos fazer um estudo comparativo entre duas situações na Billings: a Prainha e o Cantinho do Céu.

MARCO AURÉLIO: O Cantinho do Céu é ...?

CAROLINA: É na Capela de Socorro, no Grajaú.

MARCO AURÉLIO: Ah, extremo.

CAROLINA: Exatamente. O Cantinho tem todos os problemas das periferias de São Paulo, mas é um 
projeto bem singular; um dos primeiros projetos do município de São Paulo para um parque linear na beira da represa. A Prainha é um espaço de lazer há muitos anos, mas teve um processo de renovação que começou em 2010 e seguiu por um pouco mais de tempo...

MARCO AURÉLIO: IsSo. O nosso trabalho foi um pouco mais à frente, em 2013, se não me engano, 2013, 2014, por aí.

CAROLINA: Se você puder contar um pouco da sua formação, como você foi parar lá na Prainha...

MARCO AURÉLIO: Certo, vamos lá. A prefeitura de São Bernardo abriu concorrência para duas áreas com um elemento em comum: a represa. Uma era para o Parque Estoril, e a outra era para a Prainha. Uma com o viés de área pública e controlada pela prefeitura, a outra... digamos, pública também, mas só por causa da orla. A prefeitura precisava de propostas diferentes para cada área. Se você achar interessante, pode olhar o Estoril para ver as nuances que difereciam as duas áreas, exatamente, por causa dessa característica. Nosso escritório, a Urbaniza, ganhou a concorrência, e na época eu era o único arquiteto contratado, porque projetos de urbanismo não é a especialidade da Urbaniza, apesar do nome. O foco são os projetos de infraestrutura e transporte rodoviário e ferroviário. A outra empresa, que ganhou a concorrência do Parque Estoril, também não era da área de urbanismo. Era da área ambiental de resíduos. A expertise deles era aterro sanitário, coleta... Enfim, gestão de resíduos. Eles terceirizaram tudo.

CAROLINA: Nossa, uma maluquice. Sorte de São Bernardo que tinha um arquiteto na equipe da Ur- baniza, porque senão...

MARCO AURÉLIO: Eu tive um escritório antes de ir para a Urbaniza, e fiz vários projetos de urbanismo. Fizemos o projeto da mudança das calçadas da Av. Paulista para o padrão de concreto; a João Cachoeira, a 25 de Março, Fizemos o projeto da Faria Lima, que era toda despadronizada, e agora tem aquele padrão vermelho e cinza de concreto. Todos esses projetos eram do URB2, o escritório em que eu trabalhava.

\section{CAROLINA: Você se formou onde?}

MARCO AURÉLIO: Eu sou da Federal do Ceará. O urbanismo era minha experiência principal, e acabei me tornando coordenador do contrato com a prefeitura de São Bernardo. Terceirizamos muita coisa, mas éramos os coordenadores. . O termo de referência era muito vago. Queriam uma proposta para a orla e para as ruas em volta; queriam incorporar conceitos como traffic calming; tinha também que ter uma proposta de estacionamento e acesso à Prainha, o trevo de saída da Anchieta é muito complicado... Então, envolvia melhorias na região toda. E não tinha nada de componente ambiental.

Carolina: A licitação foi em que modalidade, você sabe?

MARCO AURÉLIO: Ah, pelo valor, eu acho que foi tomada de preço.

CAROLINA: Eles me passaram o valor de 180 mil. Eu achei tão baixo...

MARCO AURÉLIO: O valor não era alto pra nenhum 
dos dois casos. Era uma verba do Ministério do Turismo.

CAROLINA: Eu queria entender isso. .

MARCO AURÉLIO: Vou te falar primeiro do projeto e depois do que foi destruindo o conceito. Então, em vez de ser um projeto para a orla, era um projeto da orla, de todas as ruas que chegavam à orla, de trânsito e de estacionamento. E ainda entrou na história a área de uma indústria desativada, a Yakult.

CAROLINA: Eu vi umas fotos desse lugar.

MARCO AURÉLIO: Tivemos que fazer um estudo de tráfego detalhado, com contagem veicular, contagem de vagas de estacionamento, estudos de sentido de rua, duplicação e estreitamento de via, alargamento de calçada.

CAROLINA: Um projeto completo.

MARCO AURÉLIO: Completo; praticamente dentro do bairro inteiro. Eu quero passar uma visão geral para você formular melhor o que precisa saber, e eu poder ajudar mais.

CAROLINA: Certo. Então, tinha essa questão fundamental que era pensar esses fluxos todos...

MARCO AURÉLIO: Isso. De ambiental só tinha uma questão: proibir o acesso de veículos à faixa de areia. A faixa da...

CAROLINA: Da Emae.

MARCO AURÉLIO: É, da Emae. Isso era praticamente a única exigência. Também havia umas indefinições, que não estavam incluídas no projeto, mas estavam caminhando em paralelo, e se dessem certo... Por exemplo, melhorar ou desativar aquela estação de tratamento...

CAROLINA: Que é uma aberração absoluta.

MARCO AURÉLIO: Mas isso não fazia parte do meu escopo... Eu precisava criar atrativos, conforto, segurança, iluminação. Tinha essa intenção turística. Mas eu não precisava me preocupar com o aumento da quantidade de usuários, porque no verão ou em dias quentes, e mesmo quando o dia não está tão bonito, esse lugar fica lotado. O que precisávamos era um componente de mais qualidade na utilização; que as pessoas continuassem frequentando a Prainha, mas sem estragar tanto, sem poluir tanto, principalmente, a faixa de areia. Aí, nesse meio tempo, apareceu um novo componente: o espaço deveria ser de contemplação e não de uso, porque a água era imprópria para o banho; e se era imprópria para banho, não tinha sentido instalar quiosques, pelo contrário. A prefeitura estava se posicionando durante a implantação do projeto. Decidiu tirar todo o comércio e proibir o banho. A represa seria utilizada só para contemplação e uso náutico. Eu tive que transformar uma proposta vaga, que não dizia muita coisa, em um conceito bem construído. Entendeu? Não é para usar a represa? Então, não tem que ter acesso de pedestre. O acesso dever ser só no deque dos estacionamentos, em uma rua com controle, em que só passe quem vai deixar uma moto aquática, um barco,. O carro não fica estacionar ali, entra, descarrega, sai. As pessoas não iam tomar banho, por isso, o projeto era de calçadas elevadas, com o mínimo acesso possível à represa.

CAROLINA: Isso me chamou a atenção. Eu imaginei 
que alguma coisa tinha acontecido. Por que um deque elevado? Foi mesmo para não favorecer...

MARCO AURÉLIO: Mas isso não durou nem até o final do projeto.

\section{CAROLINA: E vieram as escadas...}

MARCO AURÉLIO: Exatamente. Houve muita pressão junto à prefeitura, de usuários, de vereadores... Tinha que garantir os quiosques no calçadão, e que eles pudessem descer e servir as pessoas, porque elas não iam tomar banho na represa, mas poderiam ficar na areia. Mas se eu vou ficar na areia, vou me molhar, não vou ficar passando calor e não usar a água da represa. Em vários lugares, uma placa informando que a água é imprópria para banho tende a ser respeitada. Na Prainha da Billings, não. E começaram os remendos. Não era para ter aquele monte de escada que aparece em alguns trechos. Era para ser um lugar de contemplação mesmo. Um prolongamento do passeio, com faixas diferentes para sentar, contemplar, para dar apoio às mesas externas dos restaurantes, para passear de um lado para o outro. As placas de concreto eram estruturais e ornamentais, com texturas que criariam uma iluminação especial. Durante o dia, as placas formariam desenhos; e à noite seriam elementos bem acesos, bem vivos, mudando de cor. Da estrada daria para ver que era um lugar bacana. Mas nada disso foi feito.

CAROLINA: Mas você tinha pensando isso ao longo do passeio todo?

MARCO AURÉLIO: Ao longo do passeio inteiro. Era uma assinatura visual do projeto. As pessoas veriam um deque, com placas grandes... Muros, digamos, para quem olhasse de longe, muros de concreto intercalados, com uma iluminação especial.

CAROLINA: A prefeitura de São Bernardo se propôs a fazer antes de conseguir a verba do Ministério do Turismo?

MARCO AURÉLIO: Para conseguir a verba do Ministério do Turismo, porque era o único lugar de onde podia vir dinheiro. O mote era turismo. Dava para fazer turismo no centro de São Bernardo? Não. Então, a prefeitura pensou: "Por que não fazemos um projeto para a represa?".

CAROLINA: Imagino que tenha sido um trânsito mais fácil, político inclusive, entre a prefeitura e o Governo Federal, que deve ter sido um facilitador. São questões que não fazem parte do meu tema, mas eu tenho que abordar. Houve algum problema nesse trâmite?

MARCO AURÉLIO: Tinha alguns problemas. O dinheiro que se esperava para a obra encurtou. Era para ter uma contrapartida da prefeitura, e uma parte seria do Ministério. A contrapartida da prefeitura não aconteceu, isso limitou o valor que viria do Ministério.

CAROLINA: Quer dizer, o Ministério ia investir desde que a prefeitura...

MARCO AURÉLIO: Demorou tanto por causa desses idas e vindas que se perdeu o timing. Outros projetos entraram na frente. O caixa foi fechando.

CAROLINA: Teve uma questão política aí, fundamental para...

MARCO AURÉLIO: Olha, é aceitável a ideia de usar recursos de turismo ali. O que é difícil entender 
é que não tivesse uma proposta ambiental forte, que a contrapartida do município não fosse pelo menos um recurso da área ambiental. Entendeu? Quiseram usar um recurso do turismo. E turismo em São Bernardo não tem recurso.

CAROLINA: Claro. É ambiental ou de urbanização, certo?

MARCO AURÉLIO: Urbanização também, porque é um bairro bem importante da cidade... Eu me sinto à vontade para falar porque não participei diretamente dessas questões políticas e orçamentárias. Eu nem acompanhei a obra. Não existia no contrato um acompanhamento de obra.

CAROLINA: Isso eu queria saber: não teve acompanhamento de obra? Foi só a entrega do projeto executivo...

MARCO AURÉLIO: Nem isso.. Só sei que alguma coisa foi feita pelas placas depois... Quando vi que não ia ser o que estava proposto, me distanciei.

CAROLINA: Claro. Havia um projeto, uma ideia, e o que foi feito não tem nada a ver nem com o projeto nem com a ideia.

MARCO AURÉLIO: Tem um centrinho comercial na praça. Tem uns nichos na rua central, onde se encaixariam alguns quiosques ou trailers. A prefeitura firmou um compromisso com o Ministério Público de tirar as barracas da areia, mas tinha que dar um destino para elas. Na areia, tinha, não lembro o número exato, umas 40, 50 barracas, mas a prefeitura afirmava que legalmente eram 15. Então, tinha que planejar para 15, os outros 35 iam perder o lugar. Mas, aí, entra o vereador, entra todo mundo, porque quando tem eleição...

CAROLINA: Eu ouvi o Ivar, que é o subprefeito, dizendo: "O projeto não tinha previsão das escadas e eu fui comentar com um vereador, e ele respondeu: 'Para ganhar eleição a gente vende até a mãe'".

MARCO AURÉLIO: Originalmente, tinha, sim, umas escadinhas de madeira e rampas para acessibilidade. O píer foi cortado ao meio. Ele ia dar acesso às embarcações de maior porte, para as pessoas fazerem passeios. Mas não era para ficarem atracadas como ficam hoje, ad eternum no mesmo lugar.

CAROLINA: Tem uma rampa, que é de uma marina...

MARCO AURÉLIO: É um estaleiro, não tinha como tirar o acesso dele. Apesar de que, se alguém tivesse bancado, o acesso era para ser o mesmo usado por todos os usuários. Mas se manteve o deque dele ali.

CAROLINA: A primeira coisa que eu pensei como arquiteta, como eu não conhecia o projeto inteiro, foi: "Gente, e esses jet-skis atravessando superperto das pessoas, isso é muito confuso". A primeira coisa que eu pensei foi que deveria ter um acesso enfim... Percebi que tinha havido um plano para o bairro inteiro, incorporando as áreas institucionais..

MARCO AURÉLIO: Quando se entende que a região do Riacho Grande não é só a Prainha; que existe um comércio forte, com bancos, restaurantes, prestadores de serviço, escolas... A conclusão é: por que não fazer um projeto de urbanismo que se comunique com o comércio já ativo do bairro? Entendeu? Então, pensamos: como fazer essa ligação, porque a maioria das construções ali são residenciais... Tenho que criar atrativos, dar às pessoas condição 
de andar por essas ruas de forma segura e confortável, reduzir a velocidade dos carros, de preferência só permitir a passagem dos veículos que fossem acessar as casas.

\section{CAROLINA: Entendi.}

MARCO AURÉLIO: Também era para ter uma área de apoio para salva-vidas, polícia, enfermaria... Ea ONG para tratar de problemas ambientais da represa. $\mathrm{E}$ para criar conexão, propusemos um grande eixo. E também tem o banheiro público. Como o banheiro precisava estar próximo à represa, mas com acesso ao sistema de esgoto, propusemos... Na época, estavam surgindo aqueles primeiros banheiros na orla de Copacabana, aqueles banheiros enterrados que não agridem à paisagem, que ficam embaixo dos quiosques, fomos até lá pesquisar... Eu fui. A prefeitura não me pagou nada por isso, nem a Urbaniza. Fui lá, pesquisei e propus algo semelhante.

CAROLINA: O projeto é muito legal...

MARCO AURÉLIO: Basicamente é isso. E aí para resolver a questão dos estacionamentos, porque teria pouca área para eles, ampliamos a área até aquela fábrica que eu falei... Na época essa área tinha sido captada por um processo de compra por uma empresa cuja sede é aqui em São Bernardo, a Mabel, uma loja de madeira. O terreno tem uma divida imensa de IPTU com a prefeitura, e outras dividas trabalhistas.

CAROLINA: É da Yakult?

MARCO AURÉLIO: É da Yakult. O terreno tem uma caixa d'água bacana, galpões imensos... Independente do que a Mabel fizesse ali, ela poderia tercei- rizar uma parte do estacionamento, porque jamais iriam usar toda aquela área.

CAROLINA: É uma área gigante, então.

MARCO AURÉLIO: Se eles quisessem, também poderiam explorar como área de eventos, em troca de divida com a prefeitura, para zerar a dívida. A torre da caixa d'água daria um mirante bacana. A empresa que explorasse o estacionamento, teria que oferecer o translado lá de cima para a área da orla. O visitante chegaria e seria orientado a estacionar o carro lá em cima, aí desceria para um piquenique com a família, de van ou a pé, e usaria a van só para subir, entendeu? Foram várias ideias, mas não aconteceu nada. Aí, vem a frustração, não é? Em linhas gerais, o projeto era esse. Começou com a reurbanização da orla, mas com as demandas de proibir o banho na represa, de retirar as barraquinhas de serviço de comida da areia, de criar acessos seguros para os pedestres, de utilizar o conceito de traffic calming, o resultado foi esse projeto.

CAROLINA: É uma pena, o Cantinho do Céu teve um projeto de arquitetura bancado pela prefeitura.

MARCO AURÉLIO: A prefeitura de São Paulo está acostumada a fazer contrapartida e depois correr atrás do recurso. Às vezes, eles até bancam para depois receber o recurso.

CAROLINA: Teve dinheiro do BID lá, foi um aporte grande.

MARCO AURÉLIO: Aqui, quiseram aproveitar que o Governo Federal era do mesmo partido que a prefeitura para fazer cem projetos ao mesmo tempo. É só ver quantas obras paradas há em São Bernar- 
do. O museu está parado, aquele buraco no Paço começou nessa época, vários corredores de ônibus, viadutos... Entendeu? Vamos começar, por que não? Nós vamos ficar aqui para sempre, vai vir dinheiro sempre, não vai ter crise, o Brasil está crescendo... vamos fazer.

CAROLINA: Acho que é a melhor análise que eu poderia ter escutado.

MARCO AURÉLIO: A briga começou em 2014. Por que o recurso dos Ministérios foi diminuindo? Quem pegou, pegou. Quem foi ficando para o final...

CAROLINA: Tem uma questão para mim, que é a qualidade da água. Curiosamente, no fim de semana passado, a represa estava com boa qualidade de água. Algo que, eu acho, acontece uma vez por ano. A água estava escurinha, aquela cor de rio mesmo. E teve a procissão de Nossa Senhora dos Navegantes. Eu vou mandar as fotos para você.

MARCO AURÉLIO: Você diz de ponta a ponta ou em uma área específica?

CAROLINA: Na Prainha. Tem muita diversidade na represa. Em São Bernardo a água estava boa.

MARCO AURÉLIO: Implantaram um programa de despoluição que ia começar a dar resultados agora. Então, não sei se já é efeito disso ou se foi só a natureza mesmo. Choveu demais, renovou tudo...

CAROLINA: Acho que foi a natureza que resolveu presentear o fim de semana de Nossa Senhora dos Navegantes. Inclusive, porque a estação de tratamento ali está completamente irregular, é antiga, a remoção não chega no nível terciário, que é o mínimo obrigatório para jogar efluente na represa. Estou tentando obter informaçōes sobre isso na Sabesp, que parece uma caixa preta. Mas é certo que essa estação não joga água em boas condições na represa. Provavelmente, a natureza levou tudo para o corpo central, para mais longe, e a água ficou boa na Prainha.

MARCO AURÉLIO: Tem também um duto da Petrobrás aí.

CAROLINA: Essa é a questão, é o maior problema, tem que tratar a água pluvial por causa dos vários "gatos" ali no meio. E são três assentamentos, certo? Riacho Grande, Vila Tupã, bem mais para a frente, e Areião.

MARCO AURÉLIO: A estação de tratamento da Prainha foi projetada só para aquele nucleozinho...

CAROLINA: Exatamente. E ainda assim, nos parâmetros atuais, não poderia nem...

MARCO AURÉLIO: Na época era o suficiente.

CAROLINA: Então, se o esgoto fosse tratado localmente, a Prainha seria salubre. Não precisaria nem pensar em tratar a represa inteira, mas localmente, isso daria conta de ter água de boa qualidade na Prainha. Vamos supor que esse fosse o principal projeto a ser viabilizado...

MARCO AURÉLIO: Ou seja, você torna o lugar ambientalmente bom de novo, automaticamente, o turismo melhora.

CAROLINA: Exatamente. É uma loucura para quem 
viu esse lugar antes. Você...

MARCO AURÉLIO: Eu sempre falei: podem gastar o quanto que for ali, se a água continuar ruim e se o uso continuar degradando, será sempre esse mesmo público. Eu só vou para a Prainha quando não tiver dinheiro para ir para outro lugar. Houve uma época em que as melhores baladas de São Bernardo, no fim da década de 1970, ficavam na Prainha. Os jovens saiam de carro de São Bernardo para ir para as baladas no Riacho Grande.

CAROLINA: Isso você sabe por ouvir as pessoas falarem...

MARCO AURÉLIO: Isso. Tanto pessoas na prefeitura, quanto amigos meus contam que lá era o "point". Como era casa de praia, o pessoal ia para lá nos fins de semana, por isso começaram as baladinhas. E, depois, mesmo quem não tinha casa, ia também.

CAROLINA: É, faz todo sentido. Deixa eu voltar... Vocês não chegaram a falar em retirar a estação?

MARCO AURÉLIO: Não, não.

CAROLINA: Nunca chegou a ser uma discussão, então?

MARCO AURÉLIO: Não.

CAROLINA: A sua relação com a represa sempre foi por conta desse projeto? Você não ia...

MARCO AURÉLIO: Eu já tinha ido uma ou duas vezes, mas pra comer em um restaurante de costela. No Estoril, fui várias vezes. É por causa do público, a Prainha não dá. As pessoas chegam com aquele garrafão de cachaça de 2,5 L pra beber durante o dia. Não dá.

CAROLINA: Eu acho, Marco Aurélio, que...

MARCO AURÉLIO: Ao lado do Estoril, tem uma área que já foi municipal, mas está cedida para a Associação dos Funcionários Públicos de São Bernardo. Eu ia muito nesse clube, porque minha esposa era funcionária pública. Na Prainha, só fui nos restaurantes.

CAROLINA: No lado do Estoril, a represa é limpa, então, essa questão de entrar na água está resolvida, certo? Eu soube que vai ter uma prova de triátlon, bicicleta na rodovia Caminho do Mar, natação na represa...

MARCO AURÉLIO: Caminho do Mar é a descida antiga da serra?

CAROLINA: Acho que pega só o trecho de planalto. Bom, enfim, obviamente quem pratica triátlon não vai se meter a nadar em água suja. É um outro perfil, certo?

MARCO AURÉLIO: Até se metem, os coitados.

CAROLINA: É? Na minha opinião, o problema não é o público, é a infraestrutura. Nas praias do Rio de Janeiro há todo o tipo de público, mas tem a infraestrutura, entendeu? E tem um certo pacto de que todo mundo usa...

MARCO AURÉLIO: É, a prefeitura de São Bernardo virou as costas para esse lugar durante décadas.

CAROLINA: Sim, sim. E é muito curioso que eu vejo nas fotos um restaurante gigante, Cantina do 
Pintor. Vou lá, e está caindo aos pedaços, trancado, fechado, não tem nada lá dentro. É uma pena. A Prainha é um lugar vivo, pulsante e vivo. Mas a população de Riacho Grande é a que mais tem problemas ligados à contaminação de água. Comparando-se todas as Unidades Básicas de Saúde do município de São Bernardo, a que tem mais problemas é a do Riacho Grande. Obviamente, porque tanto a água de poços quanto a água usada para o lazer está contaminada. Qual é a deseconomia que isso causa? Pessoas que deixam de trabalhar, enfim... Então, a Emae deu diretrizes para retirar as pessoas da faixa de area, certo?

MARCO AURÉLIO: As pessoas e os carros.

CAROLINA: E não falou em saneamento?

MARCO AURÉLIO: Não fazia parte do projeto. Era uma questão da prefeitura com a Sabesp.

CAROLINA: Quem era o responsável na prefeitura nessa época?

MARCO AURÉLIO: Tinha o pessoal da secretaria de Infraestrutura... Tinha um engenheiro, não, arquiteto. Mas ele trabalhava muito como engenheiro, fazendo vários projetos.

CAROLINA: Você lembra o nome dessa pessoa?

MARCO AURÉLIO: Não lembro de cabeça, mas tenho o contato dele no celular.

CAROLINA: Quem sabe ele se dispõe a falar comigo...

MARCO AURÉLIO: Acho que não. Ele é muito diplomático, muito escorregadio.
CAROLINA: E ele está na prefeitura ainda?

MARCO AURÉLIO: Ele não vai querer se comprometer...

Fernando Bonisio, Chefe da divisão de Turismo e Eventos do Município de São Bernardo do Campo, esteve na equipe que coordenou o projeto de revitalização da Prainha do Riacho Grande

FERNANDO: Eu venho da aviação, trabalhei na Vasp durante 13, 14 anos, e tive a oportunidade de conhecer o mundo todo, mais de 180 países. Morei na Coreia, no Japão, na Bélgica, nos Estados Unidos, sempre a trabalho. Fiz faculdade de turismo e vários cursos de extensão. Sou funcionário de carreira do município de São Bernardo e, desde 2010, trabalho na secretaria de Turismo. Ocupo um cargo técnico; sou diretor de turismo.

CAROLINA: Desde turismo industrial...

FERNANDO: O turismo industrial é o forte de São Bernardo. Temos outras possibilidades, mas, infelizmente, não há estrutura na secretária para trabalhar o ecoturismo, por exemplo.

CAROLINA: Sim, porque grande parte do município está em área de manancial. E a Prainha? Atrai muita gente de fora da cidade, não é?

FERNANDO: A Prainha tem problemas graves de infraestrutura. Eu participei do projeto de revitalização, captação de recurso no Ministério do Turismo, 
implantação do deque e tal. O projeto não se efetivou. A Prainha não tem sanitários, por exemplo.

CAROLINA: Isso é um problema bem sério.

FERNANDO: A área é APP de primeira categoria. Não deu pra instalar os banheiros subterrâneos previstos no projeto. Também há o problema do trânsito, a área tem um único acesso e não tem estacionamento. Além disso, há as questões de vigilância sanitária, que também são muito sérias. Os quiosques precisam ser fiscalizados.

CAROLINA: A vigilância sanitária é responsabilidade de quem?

FERNANDO: Da secretaria de Saúde do município.

CAROLINA: É um trabalho de educação, você não acha?.

FERNANDO: Sim. Eesse trabalho de educação inclui também os frequentadores da Prainha. A água da represa não tem banhabilidade, mas as pessoas não se importam e entram na água assim mesmo. Por isso, o Corpo de Bombeiros está presente, principalmente, durante o verão. Acho que a Prainha foi meio abandonada, mas estamos retomando agora, inclusive com a reforma do deque.

CAROLINA: Isso eu não entendo: por que o deque foi implantado e os banheiros não? Entendo que a legislação protege a área de mananciais, mas se a Prainha já se consagrou como área de lazer, recebendo milhares de pessoas, não é muito pior não ter o banheiro? Do meu ponto de vista, os órgãos de proteção tem que lidar com os processos que já aconteceram.

FERNANDO: É verdade.

CAROLINA: E a prefeitura tem alguma coisa a ver com o licenciamento dos restaurantes flutuantes?

FERNANDO: Os flutuantes estão sujeitos à fiscalização da Marinha. Tenho certeza de que a Prainha tem potencial para ser um lugar incrivel. Acho que a preocupação tem que ser melhorar a qualidade. Se tivesse restaurantes, bares, passeios náuticos, um flutuante que saísse à noite, talvez tivesse menos dano ao meio ambiente, menos resíduos deixados lá. A gente tentou mudar os costumes com a implantação do projeto, mas... Vou te dar um exemplo prático: o dono da Cantina do Luis, nem sei se ainda existe o lugar, entrou na justiça com a alegação de que a revitalização da Prainha iria afugentar seus clientes. Ele afirmou que a área de estacionamento do estabelecimento dele tinha que ser bem escura porque ali era um lugar de encontro de casais-não-casais. Ele disse: "Os meus clientes não vão vir mais aqui, porque eles não vão mais poder deixar o carro escondido".

CAROLINA: Ele tinha um drive-in, é isso?

FERNANDO: Não sei explicar. Era um restaurante que tinha baias, meio escuro. Mas resumindo, por essas e por outras, o projeto começou a perder força política.

CAROLINA: Quem fez o projeto?

FERNANDO: Acho que o nome da construtora era Almeida Sapata. 
CAROLINA: Mas e o projeto de arquitetura?

FERNANDO: Não sei, posso até pedir depois para o pessoal olhar. O convênio entre a prefeitura e o Ministério do Turismo foi em 2010; a entrega foi em 2014. Acho que foi um projeto bom, tinha um cunho turístico muito claro, e ele tem feito o papel dele. Mas eu quero dar para a Prainha o mesmo impacto que eu dei para o turismo industrial; pensar um planejamento mais robusto, inclusive com despoluição daquela área.

CAROLINA: Sim, e eu até tenho uma pergunta sobre poluição: aquela estação de tratamento de esgoto na Prainha existe há quanto tempo?

FERNANDO: O problema da poluição ali não é de tratamento de esgoto, é do controle do nível do Rio Pinheiros. Sempre que tem um problema de cheia o Rio Pinheiros entra na represa, e ele não vem tratado. Não é um problema do esgoto de quem mora ali porque esse esgoto é tratado. São interferências de fora que poluem aquela água, não tenho capacidade técnica para te explicar em detalhes, mas sei esse é o maior problema.

CAROLINA: Sim, então, a principal carga poluidora não é o esgoto do próprio Riacho?

FERNANDO: Não, isso eu tenho certeza. Tanto que é pontual, se você pega um "bracinho" da represa e sai ali, não tem essa carga de dejetos.

CAROLINA: Não seria uma alternativa ter uma gestão dedicada a essa questão ambiental e uma parceria com o próprio subprefeito? Entrevistei o Ivar outro dia; ele é superengajado, com a maior energia para fazer as coisas. Será que por lá também não é uma maneira? E também entender, qual é o papel do subprefeito nesse caso?

FERNANDO: A gente tem o olhar para lá, tanto é que participa. O festival de verão é um exemplo.

CAROLINA: O prefeito estava lá no sábado passado.

FERNANDO: A Prainha não é desguarnecida de olhar... É uma questão de prioridades, e o governo também funciona assim, também o país funciona assim. O Ivar é extremamente motivado, bem intencionado, mas o anseio mesmo da população é a travessia da represa, que era um problema da balsa, problema enorme que foi resolvido agora; é a UPA; é a creche; a escola. A gente vive num país pobre que pode ser transformado pelo turismo, mas como não se dá o devido valor ao turismo fica esse impasse. Barcelona não era nada, hoje é um dos principais destinos do mundo. O Ivar se preocupa também evidentemente com essa parte turística, mas precisa colocar a casa em ordem primeiro, vamos dizer assim. E outra coisa, que é uma percepção minha, para um bom projeto de turismo sair e ser transformador ele precisa da iniciativa privada; e o poder público atuando na infraestrutura.

CAROLINA: Ou facilitando, talvez.

FERNANDO: Vejo a iniciativa privada ali na Prainha muito difusa, um flutuante do lado do outro, um restaurante aqui do lado daquele lá. Eles não conseguem se enxergar como a somatória de forças. E vejo o povo do mesmo jeito. Então, agora nós vamos fazer o festival de verão, e sei que vai ter muita reclamação. É muito difícil agradar todo mundo, tirando turismo industrial. 
CAROLINA: Mas acho que isso faz parte da política, das relações humanas.

FERNANDO: Mas eu sou um defensor do turismo industrial. As pessoas me perguntam: "Tem alguma coisa que presta no Brasil?"; e eu respondo: "Tem, o turismo industrial".

CAROLINA: Puxando a brasa para sua sardinha, hein?

FERNANDO: Mas a Prainha é um lugar político, não tenho dúvida. Ela recebeu um impacto positivo que precisa ser melhorado, que pode ser potencializado. Mas, por exemplo, a gente queria regularizar passeio de pedalinho, lancha e motoaquática. Soltamos o edital, ninguém se inscreveu, mas se você for lá hoje vai ver placa: "Passeios de lancha", tudo à margem da legalidade. Se você quiser criar uma confusão, notifica a Marinha; eles vão lá e bloqueiam. Seria bom se eles falassem: "O que você precisa?", "Ah, precisa tirar o Arrais, precisa registrar a lancha lá na Capitania dos Portos para passeio turístico". Isso a Marinha não faz, não há um esforço. Então, o poder público olha para outro projeto e diz: "Poxa, nesse lado, nesse projeto, as pessoas estão engajadas, procuram melhorar, se preocupam com o cadastro de tudo que é importante". Como não há recursos financeiros nem de pessoal, para abarcar tudo, você vai no projeto que tem melhores possibilidades. Quer dizer, a Prainha é um lugar que a gente acompanha, tem o salva-vidas, tem o festival de verão, mas vamos dizer que a gente coloca só $30 \%$ do potencial que a gente podia colocar. Mas por quê? Vou te dar um exemplo clássico da dificuldade que todos eles ali (morador, comerciante, proprietário, tudo) têm de compreender o potencial turístico. Os vinte quiosques vendem peixe, todos eles; vendem peixe frito e bebida. Sorvete, ninguém vende? "Ah, mas sorvete eu compro por um e vendo por dois, eu só ganho 100\%; agora, a porção de camarão eu pago 20, e vendo por 100, então eu ganho cinco vezes mais." Mas e se ele vender 500 sorvetes, aqueles sorvetes de máquina que a gente vê por aí, que custam dois ou três reais. Num fim de semana com 5 mil pessoas na areia, ele vai vender muito, mas muito sorvete. Então, o custo benefício vai ser muito maior que o do camarão. Mas não tem um que entende isso.

\section{CAROLINA: É falta de informação?}

FERNANDO: Não, é protecionismo, assistencialismo barato que deixa ali quem não quer empreender. "Ah, porque é amigo daquele, é amigo do vereador, tal e tal". O deque da Prainha foi feito para contemplação, já que não pode usar água; e aí no final da gestão passada, a subprefeitura autorizou a construção de várias escadas, o que não podia. Não estou criticando e nem vou falar mal, porque eu gostava do subprefeito, morreu já, não tem nem como se defender, mas quando eu fui falar com ele, perguntar por que ele tinha autorizado as escadas, ele respondeu: "Para ganhar a eleição a gente vende até a mãe"; aí, eu levantei e fui embora. Não estou criticando, mas volto a dizer, o fator determinante é que não entendem a importância da qualificação do turismo, não se entende isso ainda. Ainda não se entende que qualificar o turismo, não significa restringir. "Ah, quem vai lá é classe C e D, esse pessoal não tem direito de se divertir, não tem direito de lazer." Claro, não tenha dúvidas. Não estamos tirando ninguém, todo mundo tem direito, é um fato. As pessoas dizem: "Eu prefiro vir aqui do que para Santos, porque para lá eu tenho que pagar pedágio, e com o dinheiro do pedágio eu como aqui". Então, vão deixar dinheiro na cidade, efetivamente é um ponto turístico. Mas 
poderia ter muito mais, a verdade é essa.

CAROLINA: Eu ouvi o prefeito dizendo que vai liberar uma verba para a reforma do deque. Imagino que seja um investimento pontual, de manutenção, certo?

FERNANDO: É. Vamos trocar as madeiras que estão danificadas. Isso, inclusive, foi um apontamento nosso, se vamos fazer o festival de verão no deque, vai ter um acúmulo de pessoas na metragem quadrada, pode até desabar tudo. Acho que, por causa da licitação, a empresa colocou uma madeira que não durou nada. Mas a prefeitura ordenou que agora a secretaria se gaste dinheiro nisso: trocar as madeiras que estivessem ruins; envernizar para proteger, talvez o mais caro ali seja o verniz naval; e refazer a pintura do deque, porque o restante não tem problema nenhum.

CAROLINA: A Almeida Sapata é uma construtora que ainda existe, você ainda mantém algum contato?

FERNANDO: Não tenho, porque, olha, eu não cuidava disso, mas posso até ver. O atual diretor de obras públicas é meu parceiro. Eu lembro que foi um rapaz de Recife que fez o projeto. Ele tinha um sotaque bem forte.

CAROLINA: E teve alguma participação dos comerciantes no projeto?

FERNANDO: Olha, eu não estava na coordenação do projeto, mas eu tenho certeza que teve muita consulta pública, muita reunião. Reunião com os comerciantes dos quiosques, eu participei de várias. A gente fez umas quinze reuniões, porque eles iam ser tirados de lá... Quais eram as condicionantes para a Emae e para a Cetesb autorizassem a obra? Resolver a situação daquelas pessoas: não ter mais estacionamento, não podia ter nenhum carro na areia. Então, tinha o projeto de criar uma Rua da Praia, e os quiosques iam para essa rua. Mas os moradores não aceitaram. Daí, recuamos o muro da estação de tratamento de esgoto e colocamos os quiosques ali. Foi o único lugar que a gente conseguiu para colocá-los.

CAROLINA: Acho que faz sentido os quiosques ficarem perto da areia. Talvez, na Rua da Praia tivesse potencial para outro tipo de comércio.

FERNANDO: Aproveitar as próprias casas para empreender ali? É, é até difícil ter outra visão do que essa que a gente está tendo. Agora, você poderia achar que vinte quiosques é muito, também acho, mas não vejo outro lugar para eles estarem.

CAROLINA: Eu não vejo lugar é para aquela estação de esgoto.

FERNANDO: Ela é aquela questão do aeroporto, né, já estava lá.

CAROLINA: Sim, não é um dado desse projeto, é um dado para um projeto a longo prazo.

FERNANDO: É, eu não sei se tinha outro lugar para ela ficar, só sei que ela já estava lá antes de tudo isso acontecer.

CAROLINA: Seria uma ideia, talvez, conversar com alguém da Sabesp para talvez...

FERNANDO: Agora, os comerciantes foram atendidos, sim.. Mas o que falta é as pessoas entenderem 
que tem que pensar no benefício da cidade. Essa situação do turismo industrial, por exemplo, mostra claramente isso. Foi uma ação criada por um funcionário de carreira que transcendeu a oposição política que tem no país. Então, se fosse sempre assim, em várias áreas, talvez o país estivesse também melhor nesse sentido.

CAROLINA: Quais são os eventos que vão acontecer na Prainha? Tem o festival de verão e, pelo que eu entendi, tem uma festa da Nossa Senhora dos Navegantes, certo?

FERNANDO: Então, festas oficiais da prefeitura: primeiro ou último domingo de fevereiro, agora fiquei na dúvida se é o primeiro ou o último, mas é a festa de Nossa Senhora dos Navegantes, tem missa, tem procissão, cortejo náutico, tudo isso.

\section{CAROLINA: Tudo isso no Riacho?}

FERNANDO: No Riacho. Então, isso é a festa de fevereiro. Em janeiro tem o festival de verão, vamos para a terceira edição agora, mas não é um evento da prefeitura, é particular. A prefeitura apoia com logística e tem um interesse político. Aqui, acho que é bom ficar claro, que o meu departamento aqui, que eu sou o diretor, avalia o interesse público da ação. Por exemplo, vem um circo para a cidade e me diz: "Vai ter pista de patinação no gelo"; " "Legal, mas não vai poder degradar o meio ambiente". Então, a gente vê o interesse público, antes de qualquer coisa, tem que passar por aqui pra ver se há interesse da prefeitura, interesse para a cidade. Evidentemente, há um interesse público para que se tenha festival de verão na Prainha.

CAROLINA: Nem sempre precisa ser iniciativa da prefeitura.

FERNANDO: Não. Por exemplo, a procissão de Nossa Senhora dos Navegantes é um evento da comunidade, liderado pela igreja, com o apoio da prefeitura. Nós não damos dinheiro, mas logística, trânsito, som. No festival de verão, a prefeitura deve colocar à disposição mais de 200 funcionários públicos para trabalhar. É janeiro e fevereiro pelo resto do ano. Mas a Prainha não é um parque fechado com portaria, segurança etc. É uma área urbana, é um local turístico mas não é um atrativo turístico na sua essência, com entrada, saída. Por isso as dificuldades, porque não tem como controlar. É diferente do Estoril, por exemplo, o Estoril abriu, fechou a portaria, saiu. Na Prainha tem batismo religioso nas águas; tem capoeira; e tem as coisas erradas: churrasco no deck, consumo de drogas; consumo excessivo de álcool; sexo entre os quiosques ali.

CAROLINA: Mas esses problemas se resolvem com Iluminação pública e fiscalização, não é?

FERNANDO: O ideal seria, concordo com você, uma viatura fiscalizando, passando lá dia e noite.

CAROLINA: No Cantinho do Céu, que é um parque linear, o outro lugar que também é objeto do meu estudo, tem um administrador e tem uma empresa contratada para fazer manutenção, então, tem uma pessoa para limpar e tem um guarda patrimonial; essas duas pessoas estão lá todos os dias. Eu vi que funciona.

FERNANDO: Aqui não é diferente, tem muito mais que isso Tem manutenção e coleta de lixo regular da prefeitura; lembrando que aquela área estava sem intervenção do poder público há mais de 40 anos. 
CAROLINA: Ah, sim. Era uma catástrofe...

FERNANDO: É de oito anos para cá que está sendo feito um processo de melhoria contínua. Tem a limpeza que é feita, dedetização, ou seja, é muito mais completo do que esse exemplo que você citou. O que eu não vejo ali, por exemplo, é uma PPP, uma parceria público-privada, mas essa é minha visão como morador da cidade. São vinte quiosques, a garagem náutica, os flutuantes, quatro restaurantes... Eu acho que, minimamente, nessa parte da segurança eles tinham que ajudar. Porque a base da GCM está lá, mas ali é a base de distribuição, a polícia você chama e ela vai, você não vê a polícia fazendo ronda preventiva.

CAROLINA: O que seria ótimo se acontecesse; a gente sabe sempre que é melhor prevenir do que remediar. Não tem uma associação de comerciantes, uma associação de moradores?

FERNANDO: A turma dos quiosques é desunida. Muitas vezes, a gente tem que ficar cuidando de probleminhas pequenos: "Ah, o Beto tem 5,30 metros na frente dele, eu só tenho 5,10 metros"; "Ah, eu tenho que andar 20 metros para ter uma escada de acesso". Eles sabiam onde ficariam as escadas e foi feita uma licitação. Eles deram lances no enelope, tudo fechadinho. Os lances mais altos começavam a escolher o lugar que queriam: “Eu dei 500, quero ficar no 1"; e assim por diante. A escolha foi feita por eles, legítima. E aí começou esse processo: "Quero abrir uma escada aqui, quero abrir mais uma aqui." Até que abriram mesmo, e foi o que eu disse para o subprefeito: "Por que fazer isso?", porque a obra não tinha nem sido entregue.
CAROLINA: Deslegitima todo o processo, é complicado.

FERNANDO: Então eu acho que é esse processo que ainda precisa evoluir muito ali, e em outros lugares também, diferente, por exemplo, daqui, do turismo industrial, que a gente está tratando com uma empresa consolidada, que entendeu o projeto. A Volkswagen não fala: "Eu participo, mas aí a prefeitura me reduz...". Não, não tem nada disso, quem está participando hoje acreditou e comprou a ideia, então deu certo. Então, já se consolidou uma coisa que não tem investimento público quase nenhum. Agora, lá na Prainha, gosto de todos os donos de quiosques, tenho o maior respeito, gente que quer trabalhar, não tem nenhum vagabundo ali, tenho o meu profundo respeito por cada um ali, claro que você pode ter mais por um do que pelo outro, normal, mas todos eles brigaram para estar ali e de alguma maneira mereceram. Eu pelo menos não tenho nenhum desafeto com ninguém que está ali na Prainha, que é muito bom, diga-se de passagem, porque eu tenho a tranquilidade de ficar o festival de verão ali e ninguém me matar. Agora, a gente é duro no que tem que ser duro. Na Cidade da criança, por exemplo, acabei de tirar um permissionário que tinha uma loja de miniatura lá que estava há 8 anos sem pagar, e eu não posso ser conivente com esse tipo de coisa. Então, esse tipo de coisa que, até complementando a minha apresentação, desde quando eu vim para cá em 2010, eu tenho plena consciência de que tudo é feito na maior honestidade possivel. Minha mãe até pergunta quando vê esses escândalos: "Mas não tem perigo?", e eu falo "Mãe, aqui não tem perigo nenhum, porque aqui a gente trabalha dentro da legalidade". Eu sei muito bem o quanto eu lutei para estar aqui, o quanto eu estudei, o quanto eu fui atrás. Poucas pessoas, se 
você pegar uma prefeitura dessa do porte de São Bernardo, com o orçamento de São Bernardo, uma prefeitura de 15 mil pessoas, mas só 30 ou 32 diretores... Eu sei muito bem o quanto é dificil você chegar e depois se manter, por isso, eu faço cada dia valer a confiança que eu tenho, não importa o prefeito.

\section{CAROLINA: Você entrou por concurso?}

FERNANDO: Sou concursado desde 2005. Em 2010 eu vim para cá, então eu já passei por três administraçōes diferentes.

\section{CAROLINA: Você é morador daqui?}

FERNANDO: Sim, eu sou morador de São Bernardo. É outra coisa que me ajuda nesse processo de transformar a cidade. Um bom exemplo: vamos construir um centro turistico, um centro de acolhimento ao turista, um centro de informações turísticas, um welcome center de turismo industrial. A sede do convention virou a sede do tour da cidade: sala de capacitação, auditório, tudo isso vai ser um diferencial. A gente não trabalha competição, porque hoje, e não falo isso com alegria, se a gente for olhar em volta da gente, ao redor, não precisava fazer mais nada...

CAROLINA: Já está acima da média.

FERNANDO: É, a gente compete com a gente mesmo e, evidentemente, a gente se espelha nas coisas positivas de quem é melhor do que a gente, $e$ também se norteia para não fazer as coisas erradas de quem é pior.

CAROLINA: Deixa eu te perguntar, para finalizar, você chegou a frequentar a represa na infância...?
FERNANDO: Não, ali não.

CAROLINA: Tem alguma memória da represa?

FERNANDO: Não, porque logo que eu fiz 18 anos eu passei a trabalhar na aviação, então eu praticamente vivi toda a minha vida fora, dos 18 aos 32 . Mas São Bernardo é a minha cidade do coração, onde eu criei meus filhos, e eu quero uma São Bernardo melhor. Mas ali especificamente na represa, na represa do lado da Prainha, poucas vezes eu tinha ido na minha vida.

\section{CAROLINA: Foi por conta do projeto mesmo?}

FERNANDO: Foi. E hoje a gente acompanha, vai com uma regularidade. Nunca fui lá em um domingo, mas assim, uma vez por ano, duas vezes por ano para almoçar. Eu não vou muito, mais pelo fato de que eu não fico à vontade, porque você vai e a pessoa não quer cobrar, não gosto dessas coisas. $\mathrm{Na}$ Estrada Velha eu até vou mais. Mas parece que você só está indo lá para comer de graça, por isso eu não frequento tanto. Mas frequento a hora que preciso, eu vou lá todos os finais de semana do festival de verão, vamos acompanhar as obras, ou seja, o que for preciso Na parte profissional, de acompanhar a Prainha, ela tem todo o meu carinho e minha atenção. 
Amauri Pollachi, coordenador do programa mananciais entre 2007-2015, coordenador da Câmara Técnica do Comitê de Bacia Hidrográfica do Alto Tietê (CBH-AT)

CAROLINA: Preparei um questionário com perguntas mais pessoais; algumas sobre o comitê; e, por último, algumas sobre o período em que você trabalhou na Sabesp. Se você puder começar se apresentando, falando sobre sua formação, seu trabalho atual...

AMAURI: A sua pesquisa está relacionada com a participação em comitês, é isso?

CAROLINA: Na verdade, acho que preciso me apresentar antes, é melhor. Eu estou fazendo uma pesquisa na área de paisagem e ambiente. Estou utilizando uma metodologia da etnografia urbana, então, o foco é na experiência das pessoas. Fiz uma seleção de dois lugares que me pareceram interessantes, porque tiveram projeto de arquitetura e planejamento do município: o parque linear do Cantinho do Céu, em São Paulo; e a Prainha, em São Bernardo. Meu interesse é entender como as pessoas se relacionam com esses lugares de lazer proporcionados pela represa. Então, claro, é impossível não tocar nas questões relativas à água. Me interessa despertar um novo modo de olhar para a represa; não só como provedora de abastecimento, mas como uma grande praia; uma opção de lazer para as pessoas. Para isso, tenho de conhecer o histórico de utilização da represa, os conflitos de uso e a situação atual, tanto do ponto de vista da legislação como das novas organizações. Então, falar sobre o comitê entra nesse lugar de atualização da situação.

AMAURI: Se for necessário assinar algum termo de consentimento...

CAROLINA: Essa é uma questão, o meu orientador... Você conhece o Eugênio Queiroga?

AMAURI: Não conheço.

CAROLINA: Ele é da área de paisagem e ambiente da FAU-USP; ele me disse que a comissão de ética deve ter uma documentação nesse sentido.

AMAURI: Se você precisar, depois eu faço a aprovação.

CAROLINA: A minha ideia é colocar as entrevistas no fim do caderno de dissertação. Eu entrevistei pessoas que têm memória do rio antes da represa. Acho que isso pode ser um documento interessante para outros pesquisadores. Então, provavelmente vou ter que lidar com essa questão.

AMAURI: Eu estou fazendo um mestrado na federal do $A B C$, e isso foi uma discussão forte na nossa turma de mestrado. Muita gente desistiu de fazer entrevista. Estou à disposição, se você precisar da minha autorização. Bem, me apresentando, tenho 61 anos, minha graduação foi em engenharia mecânica na USPe, na sequência, fiz História, também na USP. Tenho curso de especialização e, atualmente, sou mestrando, na Universidade Federal do ABC, e pesquisador num projeto temático na Fapesp, sob a coordenação do professor Pedro Jacobi. O projeto trata da "Governança Ambiental na Macrometrópole Paulista em face das Mudanças Climáticas. São mais de 50 pesquisadores no projeto. Durante 31 anos, fui funcionário da Sabesp e passei por diversas gerências, mas minha maior vivência foi na área de produção e todo o seu processo, desde captação 
e o tratamento de água, reservação e distribuição. Durante quase 10 anos fui gestor da distribuição de água da região metropolitana de São Paulo; todo o controle dessa operação estava sob minha supervisão. Depois dessa passagem pela Sabesp, estive durante 10 anos na secretaria de Saneamento e Recursos Hídricos; atuei na gestão no Programa Mananciais, financiado pelo Banco Mundial, e no PAC Mananciais, financiado pelo Orçamento Geral da União, onde o projeto de urbanização do Cantinho do Céu foi desenvolvido. Fazíamos o repasse de recursos aos projetos do PAC Mananciais, que previa a urbanização de 45 assentamentos precários, incluindo o Cantinho do Céu. Depois. ficou-se em 27 assentamentos, nos quais realmente houve intervenções em vários níveis. O Cantinho do Céu foi um deles.

CAROLINA: Minha visão de fora é que o Cantinho do Céu é um projeto fora da curva, não do ponto de vista de urbanização e infraestrutura sanitária, mas considerando que ele se tornou referência de um tipo de intervenção incomum até então. Inclusive, em alguns trechos, a lei dos 50 metros da linha d'água não é estritamente respeitada.

AMAURI: É verdade. Esse é um aspecto que podemos desenvolver. Mas antes, só para fechar, a Prainha de São Bernardo também é uma área em que nós tivemos alguma atuação, porque é uma área praticamente colada à captação de água do sistema Rio Grande. Na época, fui gestor da área de produção sul na Sabesp. A ideia era fazer um parque com instalações adequadas. Chegamos a esboçar uma proposta, mas por uma série de dificuldades com a EMAE e com a prefeitura de São Bernardo sobre quem faria o quê, o projeto não se concretizou. A Sabesp tinha se comprometido a ceder uma área para a construção de um núcleo de apoio, visitação e educação ambiental. Nossa ideia era essa, aliar a preservação ambiental à visitação, para que o público fosse conscientizado sobre questões ambientais. Essa era a ideia, mas não houve comprometimento efetivo entre as partes.

\section{CAROLINA: São muitos atores, não é?}

AMAURI: São muitos atores.

CAROLINA: Estado, município...

AMAURI: Tem a EMAE... Não foi possível levar a ideia adiante; nem com o Programa Mananciais conseguiu-se encontrar uma solução. Desde 2001, atuo no Comitê da Bacia do Alto Tietê e no Sistema de Recursos Hídricos, mas minha presença mais efetiva se dá a partir de 2007, quando fui da secretaria de Saneamento e de Recursos Hídricos. Essa presença se mantém até hoje. Atuei com adjunto do secretário executivo, assumi a secretaria executiva por dois anos, de 2015 a 2017. Atualmente, sou coordenador da Câmara Técnica de Planejamento e Articulação do comitê e represento a sociedade civil. Também sou diretor da Associação de Profissionais Universitários da Sabesp e representante dessa entidade no plenário do comitê. Continuo nessa função, mesmo desligado da Sabesp e da secretaria há um ano, continuo atuando no sistema. Enfim, estou à disposição para as perguntas agora.

CAROLINA: Algumas perguntas são mais pessoais, porque tratam de entender como as pessoas se relacionam com a represa. Você, por exemplo, qual é sua relação com a Billings?

AMAURI: Olha, é uma relação bastante forte, porque 
durante boa parte da minha vida profissional eu estive em contato com a Billings, e também com a Guarapiranga, muito mais do que com o sistema Cantareira. Desde o início da carreira, na Sabesp, trabalhei junto à barragem da Guarapiranga, na área de manutenção. Como gestor de produção da Região Sul, o contato com a Billings era muito forte, principalmente no processo de captação e do tratamento de água. Participei do subcomitê da Billings em 2000-2003, e em 2013-2015. Atuei na discussão da legislação específica de proteção de mananciais da Billings, lei 13.579, se não me falha a memória. Sempre dediquei forte atenção à questão dos mananciais. Nos últimos 15 anos, a Billings sempre esteve presente na minha vida. Participei daquela discussão intensa, no final dos anos 2000, sobre a flotação das águas do Rio Pinheiros e a transposição das águas para a Billings, até que se chegou à evidente conclusão de que aquilo não era viável nem técnica nem econômica nem ambientalmente.

CAROLINA: Em 2000, já tinha captação no braço de Itaquaquecetuba?

AMAURI: Já, foi inaugurado em 2000. Eu atuei no início da operação desse sistema adutor. Era muito importante que as águas transpostas da Billings para a Guarapiranga tivessem um controle de qualidade extremamente rigoroso. Havia uma série de sistemas que faziam o monitoramento, praticamente em tempo real, da qualidade das águas. Era uma condicionante ambiental, a implantação de uma wetland, uma várzea manejada na chegada das águas da Billings na Guarapiranga, mas o sistema de wetland nunca foi implantado. Teve projeto faraôni$\mathrm{co}$, teve projeto mais modesto, teve projeto-piloto...

\section{CAROLINA: E não saiu o piloto?}

AMAURI: Saiu. A implantação do piloto fazia parte do Programa Mananciais. A Sabesp licitou duas vezes, mas ninguém se interessou. A divulgação das licitações foi feita, mas não houve esforço suficiente. A Sabesp podia ter convocado alguns empreiteiros. Estou pensando aqui que, como você está fazendo uma pesquisa, seria interessante você conhecer a tese de doutorado do Edson Escames. Ele é um funcionário da EMAE, e a tese dele discute a possibilidade de fazer a reversão de águas do Rio Pinheiros para a Billings, utilizando aquela parte chamada de corpo central, onde estão o Cantinho do Céu e a Península do Cocaia. Ele propõe utilizar essa área como área de tratamento e, assim, aumentar a capacidade de geração de energia e ter águas mais limpas no restante do corpo da represa.

CAROLINA: Mas isso estaria sacrificando alguns... Curioso, porque um jornalista chamado José Contreiras...

AMAURI: Sim, ele é do MDV.

CAROLINA: Esse jornalista escreveu um texto, não é um texto acadêmico, em que ele fala dos vários projetos de compartimentação de vários trechos da Billings. Já houve uma compartimentação na barragem Anchieta. Poderia se pensar em projetos em que determinadas áreas da Billings fossem compartimentadas. Imagino que...

AMAURI: A compartimentação não se adéqua à Billings. Se os braços forem compartimentados, a represa, pensada como um todo, não responde bem. Mesmo que hoje haja uma contribuição importante dos braços na recuperação da qualidade, 
a dinâmica do reservatório não fica melhor, fica bem pior com a compartimentação.

CAROLINA: Pra mim, parece uma loucura o fato de a represa unir seis municípios da região metropolitana. Na FAU, se estuda a possibilidade do transporte fluvial pela represa, mas alguém disse que não...

AMAURI: Não tem sentido, porque não tem correlação com a melhoria da qualidade ambiental.

CAROLINA: Agora uma pergunta: há diferença significativa na quantidade de lodo depositado nos vários trechos da Billings? Existe uma contaminação no fundo da represa, e isso é um tema complexo. Qual é a viabilidade de dragar esse material?

AMAURI: É muito difícil, realmente, você fazer essa dragagem. Talvez com a ideia do Edson Escames... Utilizando a porção chamada bacia inicial, criando uma espécie de barreira e tratando a água nessa transposição. Com isso, melhoraria um pouco a qualidade.

CAROLINA: A parte inicial é provavelmente a área cuja contribuição de carga é mais significativa.

AMAURI: Sem duvida, começa a partir daí.

CAROLINA: Algumas pessoas dizem que o bombeamento do rio quando tem enchente é pior, em termos de carga, do que essa área da Capela do Socorro. Há estudos que indiquem isso?

AMAURI: Olha, de fato é. A Billings tem uma capacidade de regularização em torno de $15 \mathrm{~m} \Downarrow$ de água por segundo. Com o bombeamento, de 5 a $6 \mathrm{~m} \otimes$ por segundo são acrescidos à capacidade da represa, mesmo que se passem meses sem que se opere o sistema de bombeamento.

CAROLINA: Nossa, é muita coisa.

AMAURI: A represa opera com grande capacidade em períodos curtos, períodos de verão.

CAROLINA: São $15 \mathrm{~m} \rrbracket$ mais $6 \mathrm{~m} \rrbracket$ quando bombeia, certo?

AMAURI: Isso. Esses dados estão na pesquisa do Edson Escames. Acho que vale a pena você dar uma olhada; a pesquisa é recente. A ideia é fazer o tratamento na parte inicial, que é onde está o Cantinho do Céu. O Cantinho do Céu é fácil, o clima é superaberto.

CAROLINA: Quer dizer, estaria fora o braço do Varginha, certo?

AMAURI: Isso. Seria antes da Península do Cocaia.

CAROLINA: Ele já defendeu? Será que na biblioteca é obrigatório entregar uma versão em .pdf?

AMAURI: Sim, e o arquivo fica aberto. Mas se você quiser posso passar o contato dele, e você pode falar em meu nome. Você quer ver fotos do Cantinho do Céu?

CAROLINA: Você tem uma quantidade de fotos, hein? São da época da implantação?

AMAURI: Essas fotos são de agosto de 2010. Cantinho do Céu, Gaivota, antes e depois das obras.

CAROLINA: Quem sabe a gente faz uma troca, eu 
te dou as mais atuais e...

AMAURI: Como você falou, o Cantinho do Céu ficou como uma referência durante muito tempo, o projeto é muito interessante; foi feito pelo Boldarini.

CAROLINA: Entrevistei o Boldarini e a Melissa, que trabalhava com ele na época. Ela fez um mestrado focado nas remoções; ela tem muito material.

AMAURI: A prefeitura levou o projeto para a Bienal de Arquitetura de Veneza na época. Se não me engano, foi em 2010 ou 2011. Teve uma boa repercussão na Bienal; é um projeto muito interessante. Uma área ocupada irregularmente, com assentamentos precários, que recebeu uma solução de urbanismo muito boa e, inclusive, um parque linear. O parque, embora esteja praticamente dentro da faixa dos 50 metros da represa, na faixa não edificante, se adequa muito bem, porque dá uma destinação pública a essa faixa.

CAROLINA: Aquilo que não tem destino, tem qualquer destino; onde não pode nada, pode tudo. Até o crime organizado respeita a área do parque. Tudo bem, há um arranjo social que permite isso, mas acho que o parque conseguiu mudar o status do lugar.

AMAURI: Sim, tanto que toda vez que ele recebia delegação do Banco Mundial para inspeção geral, vinha muita gente junto para conhecer o projeto. Inúmeras delegações do Banco Mundial visitaram esse projeto; visitaram também o projeto de São Bernardo, em Alvarenga. Não era projeto nem do PAC Mananciais nem do Programa Mananciais, mas queríamos replicá-lo no assentamento do Areião.
CAROLINA: Perto da Prainha, não é?

AMAURI: Exatamente. Umas das questões centrais para o aproveitamento da região da Prainha era fazer a urbanização do Areião e dar a destinação correta para o esgoto.

CAROLINA: O esgoto do Areião não vai para o compartimento Rio Grande superior?

AMAURI: Não, vai para o compartimento central.

CAROLINA: A captação da Sabesp é ali do lado, certo?

AMAURI: Sim. O esgoto deságua ao lado da Prainha. É uma situação ruim, inclusive, porque impede o aproveitamento de todo aquele espaço. Nós levamos comitivas do Banco Mundial para conhecer o Cantinho do Céu, mas acho que faz uns três anos que eu não vou ao parque linear. Recentemente, estive no Gaivotas para ver uma ocupação que voltou; a área tinha sido desocupada à força em 2007. Fomos fazer um trabalho de investigação e conhecimento da área. Lembro que todas as visitas ao Cantinho do Céu eram previamente marcadas, e o pessoal fazia a limpeza. Uma vez, aparecemos meio às pressas, e mesmo assim dava para perceber que havia uma conservação. Os moradores reportavam que eles mesmos se organizavam para manter a área bem cuidada. Eles se cotizavam para manter as lixeiras; faziam operações para recolher o lixo; buscavam conscientizar os frequentadores, principalmente o pessoal de fim de semana, sobre a importância de preservar o espaço.

CAROLINA: As pessoas pensam no parque. É uma questão orgânica, que move a apropriação 
do espaço. As pessoas foram entendendo que o parque é o lugar onde as crianças brincam, onde as famílias podem conviver. Acho que isso teve um tempo de depuração. Hoje em dia, há vários grupos de ativos no Cantinho do Céu, desde treinamento de navegação até realização de feiras de empreendedorismo. Eu esperava ver um parque com todos os problemas de uma área pública no Brasil. Encontrei algo diferente, que me emocionou.

AMAURI: O parque estava sob a administração da secretaria municipal da Habitação, depois foi passado para a secretaria do Verde e do Meio Ambiente. Nenhuma tem estrutura compatível.

CAROLINA: Eles licitaram. Atualmente, a parte de administração é terceirizada, pelo menos a parte de...

AMAURI: Vigilância. Mas a organização da comunidade foi muito interessante. Eles criaram instrumentos próprios de preservação. Tem o passeio, o caminho da orla, a área de bicicleta, os equipamentos de exercício para crianças e idosos. Eu percebia essa preservação.

CAROLINA: Tudo isso ainda está lá. E é diverso, tem a turma do skate, tem as turmas das feiras, tem a turma do conjunto da navegação, tem a turma do grafite; são muitas turmas, e todas conversam entre si. E o ponto de encontro é o parque.

AMAURI: Eu acho isso interessantíssimo.

CAROLINA: O que me chama atenção é que na Prainha perdeu-se a oportunidade de fazer um parque com infraestrutura adequada. Tudo bem, o lugar é incrivel, é utilizado, mas do ponto de vista de urbanismo é o mínimo para menos. Você disse que há uma área da Sabesp na Prainha...

AMAURI: Essa área é onde está a barragem da Sabesp, a captação. Também tem uma área que vai até o alto de morro. Tem uma área mais elevada, onde existia uma edificação que a Sabesp desapropriou. A proposta era criar um espaço de lazer que as pessoas pudessem utilizar. São mais ou menos 3.200 famílias e vários assentamentos interligados, Vila dos Estudantes, Vila Sabesp, Areião, chamam tudo de Areião. A ideia era fazer um projeto de urbanização; inclusive era do Boldarini; o projeto existe (executivo, orçamento e tal). Nada aconteceu porque o Banco Mundial resolveu encerrar o contrato com a prefeitura de São Bernardo.

CAROLINA: Eu queria saber, por que a estação de tratamento de esgoto no Riacho Grande ainda não foi desativada?

AMAURI: Ela tem que ser desativada.

CAROLINA: Ela está fora da lei dos mananciais, não poderia estar ali. Me parece pequena e não tem como expandir. Além disso, a estação está no water front, que é a coisa mais legal da Prainha

AMAURI: Isso é totalmente inadequado, é uma estação para tratamento primário. A remoção da demanda bioquímica de oxigênio é muito baixa, só chega a $20 \%$, não vale a pena.

CAROLINA: Mas tem uma solução, certo?

AMAURI: Há duas alternativas viáveis: substitui-se esse sistema por um que faça o tratamento por membranas filtrantes, cuja eficiência é muito boa, e que ocupe um espaço pequeno; ou levam-se os 
esgotos dessa área para o coletor tronco, que está a aproximadamente três quilômetros.

CAROLINA: Eu tenho muito interesse em saber com quem eu poderia falar na Sabesp para entender qual é o futuro disso, o que está sendo pensando.

AMAURI: Você pode consultar o Projeto Tietê. Aárea de planejamento regional pode dar informações. Mas acho que seria interessante você fazer perguntas no portal da Sabesp, o portal da transparência.

CAROLINA: Eu consigo via portal da transparência?

AMAURI: Sim. Você pode mandar um mapa com a área delimitada e a pergunta: " Que solução está sendo dada para o esgoto na área que drena para a Prainha do Riacho Grande?'. Eles têm prazo para dar a resposta. Sei que o projeto existe; precisa só ver qual é a solução, qual é o perfil de pesquisa, qual é o aproveitamento no Riacho Grande, qual é o objetivo...

CAROLINA: Dá para dizer que, dependendo da região da Billings, mesmo em trechos ligados ao corpo central, a qualidade da água está vinculada à descarga de esgoto próxima? Ou não?

AMAURI: Sem dúvida.

CAROLINA: Eu sempre fico imaginando: bom, se esse esgoto for tratado adequadamente, essa água tem chance de ter qualidade pelo menos razoável...

AMAURI: Sem dúvida.

CAROLINA: Porque é um pouco chocante ver as crianças entrando na água. Ninguém liga para os avisos.

AMAURl: É impossível controlar isso.

CAROLINA: Para mim, a única solução é realmente atingir níveis satisfatórios da água. Hoje mesmo, vou entrar no portal da transparência da Sabesp para entender como está sendo tratada a questão da estação de Riacho Grande. O que você disse mesmo sobre o tipo de tratamento feito nessa estação?

AMAURI: Essa estação é uma lagoa de tratamento no Riacho Grande, é um tratamento primário, de remoção baixíssima de esgotos.

CAROLINA: E tem mais um fator que é muito complexo: ao longo da parede da estação de tratamento, instalaram vários quiosques, licitaram e venderam os quiosques. Então você imagina que atrás da parede onde estão os quiosques de comida, há uma estação de tratamento de esgoto. O cheiro de esgoto é permanente.

AMAURI: Isso é insano.

CAROLINA: A responsabilidade pela fiscalização da água é da Cetesb, certo? A fiscalização feita pela Sabesp não precisa ser divulgada, é para uso interno. A Sabesp não tem o compromisso de fazer esse controle, estou certa?

AMAURI: O Programa Mananciais divulgou um relatório de monitoramento de qualidade da água da Billings. Eu não estava mais na coordenação do programa. A qualidade da água na Billings vai meIhorando à medida que nos aproximamos da Serra do Mar, no reservatório de Rio das Pedras. Tanto que o braço Rio Pequeno tem água de qualidade 
bastante boa.

CAROLINA: E ele é ligado ao corpo central?

AMAURI: É. Mas o fluxo de águas percorre o corpo central e vai para o Rio das Pedras, então, o espaço junto à barragem que separa do Rio Grande não é tão ruim.

CAROLINA: Mas não bom o suficiente para as crianças entrarem e beberem.

AMAURI: Se tiver um trabalho de afastamento e coleta na sub-bacia do Riacho Grande; se não tiver lançamento de esgotos diretamente, o espaço pode se tornar balneável.

CAROLINA: Não é uma coisa impensável, certo?

AMAURI: Não. Tem uma distância significativa do fluxo do corpo central em relação a esse ponto. Ou seja, não é uma área em que as águas, mesmo que haja bombeamento, recebam...

CAROLINA: Deve ter um pouco de carga ali, mas de alguma maneira vai estabilizar.

AMAURI: Se houver o afastamento de esgoto dessas áreas, pronto. Se você fizer uma consulta à Sabesp a respeito dos planos para essa área, qual será a pergunta? Porque eles vão responder só o que você perguntar.

CAROLINA: Tem que ser preciso, uma tacada.

AMAURI: "Quais são os investimentos previstos para coleta, tratamento ou afastamento de esgotos da bacia nessa região?"; "Qual é a data prevista de implantação?"; "Quais são os resultados e benefícios esperados?'; "Dentro do Projeto Tietê, o que está previsto para essa área?". Mas vai precisar de urbanização, não dá para fazer esgotamento dessa área se não fizer urbanização. E, na gestão atual do município de São Bernardo, isso não será feito em hipótese nenhuma, não tem recurso. Acabou o recurso do PAC, não tem mais recurso de organização civil, o Governo Federal fechou tudo.

CAROLINA: A única chance seria o Governo Federal? Pelo estadual não...

AMAURI: Não tem jeito. A coisa estava toda negociada. Era uma soma de recursos do Banco Mundial, uma parcela do Governo Federal e uma pequena contrapartida do município. Acontece que o Banco Mundial colocou uma série de restrições com relação ao reassentamento. Eles queriam que os proprietários que faziam sublocação, mesmo em local de risco, fossem totalmente ressarcidos, quer dizer, se alguém alugasse três quartinhos para famílias inteiras, mesmo que fosse em área de risco, o Banco Mundial queria que esse sujeito tivesse acesso a três moradias novas. Era impossivel, pela legislação não dava.

CAROLINA: E do ponto de vista econômico...

AMAURI: É a superexploração do mais pobre. O sujeito está tendo renda em cima da locação de uma área que nem é dele, ele não tem a propriedade. Houve toda essa discussão, e o negócio emperrou.

CAROLINA: Nossa, mas foi por isso?

AMAURI: Quem impediu a implantação desse projeto foi o Banco Mundial. 
CAROLINA: Que loucura.

AMAURI: O projeto executivo foi concluído. Tem até um diagnóstico: são 3.200 famílias cadastradas; adutora; oleoduto; o Rodoanel. Estava superbem trabalhado. A área de reassentamento atenderia 1.140 remoções. O projeto do Boldarini era muito bonito.

CAROLINA: Ele é muito bom arquiteto.

AMAURI: O projeto lembrava o Cantinho do Céu. A ideia era revitalizar, tornar o espaço vivo, ter comércio, cabeleireiro...

CAROLINA: Ser um centrinho comercial.

AMAURI: O valor do investimento era de 276 milhões.

CAROLINA: Uma curiosidade, o Banco Mundial empresta para o município?

AMAURI: O município tem que pagar, normalmente tem carência de cinco anos, e o pagamento se dá ao longo de 20 anos, com juros. Era um orçamento pesado. Então, acho que vale a pena perguntar à Sabesp qual é o planejamento para essa área, e para a sub-bacia que está, digamos, na frente. Você precisa delimitar a área.

CAROLINA: É. Precisaria dar uma olhada nas curvas, entender um pouco mais...

AMAURI: Você pode delimitar em Vila Balneárea e Jardim Jussara.

CAROLINA: Porque aquele corregozinho que a gente vê ali já corre na outra direção. Acho que deve ter uma linha de...

AMAURI: Sim. É um eixo paralelo ao Rodoanel. A delimitação da Billings está na...

CAROLINA: Na lei específica, certo?

AMAURI: Na lei específica.

CAROLINA: Amauri, eu tinha a intenção de fazer uma espécie de organograma para entender como se organizam esses órgãos todos. Eu fui mapeando: primeiro a lei dos mananciais em 1975; depois, fiz um salto grande, a Política Nacional de Recursos Hídricos na década de 1990; no fim da década de 1990, a definição e recuperação da área de mananciais; e mais recentemente, em 2009, a lei específica da Billings. Você sente falta de algum outro marco importante? Eu imagino que já é tempo de uma revisão da lei específica, não é?

AMAURI: Sim. Foi proposta uma revisão, mas não foi bem-sucedida. Houve resistências. A proposta era simplificar e tornar mais claros alguns instrumentos que dificultam o licenciamento para a recuperação urbana de assentamentos precários. A legislação do Alto do Juquery, de 2016, e a do Alto Tietê Cabeceiras, de 2015, deixam mais bem especificado o que pode ser objeto de recuperação. Tem um artigo que eu encaminhei...

\section{CAROLINA: Eu posso ler esse artigo?}

AMAURI: Então, o artigo mostra os prescritivos do planejamento regional dos mananciais de São Paulo, trata basicamente dessas questões. Ele apresenta precedentes nas áreas de mananciais. Há referências bibliográficas. E eu tive acesso à uma pesquisa de 
mestrado muito interessante que tratava da implantação do bairro de Interlagos. Muito interessante ver como....

CAROLINA: Como tudo começou.

AMAURI: O Cantinho do Céu é um exemplo. Em 1962, já tinha ocupação de chácaras. Na data da lei de proteção 1.172, em 1976, já havia arruamentos identificados.

CAROLINA: Eu ia fazer uma brincadeira, parece a lei de urbanização, não a lei de proteção.

AMAURI: Pois é. Já existiam loteamentos desenhados, que pela legislação eram ilegais. Em 1994, a ocupação é total, com o Cantinho do Céu e o Gaivotas. Foi um descontrole; em vez de se fazer um controle, fez-se o contrário, houve um processo de incentivo à ocupação.

CAROLINA: Acho que o pessoal do Lab/Hab tem estudado isso há um tempo, o papel da lei na indução da ocupação.

AMAURI: Tem coisas da Raquel Rolnik, da Kato, colega nossa UFRJ, da Luciana Ferrara.

CAROLINA: Foi por ela que eu cheguei até você.

AMAURI: Usei um livro que ela publicou. Dou um panorama da legislação no artigo. Tem o decreto de 1998 que previa saneamento nas áreas ocupadas, mas não permitia pavimentação. Era um negócio meio esquizofrênico

CAROLINA: Muito. Até porque a pavimentação ajuda a evitar o assoreamento.
AMAURI: No Cantinho do Céu, a implantação do sistema de água aconteceu por causa do plano emergencial de 1998. A área era prioritária porque a pressão era muito forte ali.

CAROLINA: Mas foi por conta da ação civil, não?

AMAURI: A ação civil não tinha pressão política e popular. Eram 10 mil pessoas ali. Não dava para fazer abastecimento com carro pipa. A Sabesp, em 1992, tinha feito a instalação de alguns reservatórios precários.

CAROLINA: Agora eu estou entendendo. Você está falando da distribuição de água

AMAURI: Isso. Em 1992, a Sabesp fez a instalação de alguns reservatórios precaríssimos de 5 mil litros. Isso iniciou o comércio de água; tinha o dono da água do reservatório...

CAROLINA: Eu soube. Teve morte, foi bem pesado...

AMAURI: Só se resolveu com o plano emergencial. Em 1998-1999, foi implantado todo o sistema de abastecimento de água da região; e com o Projeto Tietê foi implementado o sistema de esgotos. Não teve urbanização, mas o sistema de esgotos foi feito; por isso, existem dezenas de estações elevatórias no Cantinho do Céu. Se não me engano, eram 15 estações elevatórias, algumas foram desativadas com a reurbanização. Com a pavimentação, a drenagem. o sistema foi totalmente refeito. A legislação melhorou muito.

CAROLINA: Então, eu estava tentando entender quem são os atores das decisões sobre os manan- 
ciais. Por exemplo, o comitê da bacia tem partes governamentais e partes da sociedade civil. Como isso funciona? A nomeação é feita pelo governador? Quem que são os atores presentes no comitê?

AMAURI: Pela legislação do estado, os comitês devem ser tripartites, $\nabla$ do estado; $\nabla$ do município; e $\bigotimes$ da sociedade civil. A sociedade civil tem uma ordenação por categorias: ONG's, defesa ambiental, defesa de direitos difusos, universidades, institutos de pesquisa, usuários, atividades técnicas, são várias categorias. As entidades se cadastram, respeitando os requisitos definidos no estatuto do comitê, e participam de uma eleição dentro da sua respectiva categoria. Por exemplo, dez ONG's se cadastram, mas só há três vagas no comitê, então, as entidades elegem três titulares e três suplentes. No caso dos municípios, todos da bacia do Alto Tietê têm assento. São 36 assentos municípios no comitê. A bacia do Alto Tietê abrange 40 municípios, mas nem todos fazem parte da região metropolitana. São Roque é um exemplo. Também estão fora Guararema e Santa Isabel, que estão em outras bacias hidrográficas. E Vargem Grande Paulista, que embora faça parte da região metropolitana e tenha uma porção na bacia do Alto Tietê, não faz parte do comitê, porque a maior parte do município está na bacia do Sorocaba. Todos os demais municípios estão presentes; 36 ao todo: 18 titulares e 18 suplentes. Do estado, são 18 representantes indicados por secretarias e órgãos estaduais. A Cetesb tem uma vaga, a secretaria do Meio Ambiente tem uma vaga, a secretaria da Energia tem uma vaga e assim por diante. Normalmente, o presidente no comitê é escoIhido entre os prefeitos do conjunto de municípios; o vice-presidente é um representante da sociedade civil; e o secretário executivo normalmente é do estado, do órgão do estado que faz a administração de recursos hídricos.

CAROLINA: Tudo isso acontece por votação?

AMAURI: Por votação Normalmente, a reunião de eleição e posse é feita no fim de março. Mas o comitê tem um problema sério de participação.

\section{CAROLINA: Excesso ou falta?}

AMAURI: Falta de participação dos municípios e de alguns segmentos da sociedade civil O comitê não corresponde à forma como foi concebido. Se você buscar na literatura, vai ver muitas questões, muitas análises de quando foi criado o sistema nacional de gestão de recursos hídricos.

CAROLINA: Isso no final da década de 1990?

AMAURI: Com a lei federal de 1997. Essa legislação muito bem vista na época. Representou a abertura de uma espécie de arena de discussões regionais, em que se tratasse a questão da água e outras questões relacionadas ao uso do solo. Mas isso foi se esvaziando ao longo do tempo. São muito raros os comitês em que existe participação intensa e presença efetiva dos representantes. Normalmente, só comitês em que se trata de escassez de água são fortalecidos, e escassez de água é vista como questão política.

\section{CAROLINA: E não é o caso do Alto Tietê?}

AMAURI: O Alto Tietê importa água de bacias vizinhas, mas não existe articulação política relacionada à escassez. Embora nós tenhamos passado por uma crise extremamente grave entre 2013 e 2016, não houve, principalmente na esfera municipal, a per- 
cepção de que isso fosse uma prioridade da região. A articulação política na região metropolitana de São Paulo é sensivelmente desgastada. Não há unidade como existe na região de Campinas e Piracicaba, onde a escassez de água é vista como um problema grave desde os anos 1980. Não é assim aqui, talvez precisemos passar por outra crise hidráulica.

CAROLINA: É, talvez... Mas voltando, do ponto de vista executivo, as ações de uso e ocupação do solo são atribuições dos municípios?

AMAURI: Sim. Está no Estatuto da Cidade.

CAROLINA: Mas, por exemplo, que ações pensadas dentro do comitê estão vinculadas a essa atribuição dos municípios?

AMAURI: Eu diria que a participação dos municípios tem sido muito pequena. Vou fazer uma comparação, na gestão passada, São Bernardo esteve presente no comitê, fazendo críticas, sugestões, cobranças, foi uma presença importante.

CAROLINA: São Bernardo tem 70\% de seu território em área de mananciais, não é?

AMAURI: Exatamente. Fizeram cobranças relativas à revisão da legislação, propuseram, articularam dentro do consórcio intermunicipal do ABC para ter força na revisão de instrumentos etc. O que se produziu foi uma resolução da secretaria do Meio Ambiente, publicada no começo de 2017, que regulamentou os procedimentos para licenciamento do Programa de Recuperação de Interesse Social, voltado justamente a assentamentos precários na região. Isso foi fruto da pressão dos municípios, liderados por São Bernardo. São Paulo também estava nesse processo, mas eu diria que num plano mais secundário. Na gestão passada, houve uma participação maior do comitê, quando, um pouco tardiamente, o município de São Paulo cobrou ações do estado sobre a crise hídrica, tanto que foi criado o Comitê da Crise Hídrica, que chegou a se reunir algumas vezes, mas foi perdendo razão porque...

CAROLINA: Choveu, não é? O governador foi salvo.

AMAURI: Depois, o estado apresentou um plano de contingência. "Uma papelada que não serviu para nada", segundo afirmaram. Claro que é preciso ter um plano de contingência, mas tem de ser compactuado, todo mundo precisa estar ciente, a sociedade tem que saber. O plano de contingência existe, mas a sociedade não sabe. Não está pactuado com todos os atores que participam do processo, realmente ficou só um papel. Desde 2017, a atuação dos municípios tem sido nula. São Bernardo sequer envia representante, São Paulo enviou representantes absolutamente descolados da realidade.

CAROLINA: Nenhuma afinidade técnica ou política com o tema?

AMAURI: Vão lá para, digamos, cumprir tabela na lista; estão presentes, mas não contribuem, não têm proposta, não criticam.

CAROLINA: Parece que isso se relaciona ao esvaziamento da política como um todo, não é só o caso do comitê. Mas, bom, as questões sobre o comitê, a organização, a escolha da presidência, as eleições... E como e quando acontecem as reuniōes?

AMAURI: Normalmente, a cada dois meses, mas não é uma determinação. Precisa ter a construção 
de uma pauta... Há um site do comitê que você pode consultar.

CAROLINA: Eu consultei, baixei bastante coisa.

AMAURI: Você tem, por exemplo, a agenda do ano passado, as reuniões de câmaras técnicas, os plenários... Este ano ainda não aconteceu nenhum evento, sei que vai ter um no final de fevereiro. $O$ site mostra o estatuto, a estrutura, os subcomitês, que são de caráter consultivo, as câmaras técnicas, a agência da bacia, que está vinculada ao suporte técnico-administrativo, toda a estrutura está aí.

CAROLINA: Como os recursos do FEHIDRO são captados e como se decide aplicá-los?

AMAURI: São duas fontes. Uma são os recursos de compensação de geração de energia elétrica, que são divididos entre os municípios onde existem reservatórios de geração de energia, a União e os estados. Em São Paulo, esse valor vai para o FEHIDRO. A outra parte se refere à cobrança pelo uso da água.

CAROLINA: No caso de São Paulo, a Sabesp.

AMAURI: A Sabesp recolhe um centavo por $\mathrm{m} \otimes$ captado. O custo para a empresa é superbaixo.

CAROLINA: As discussões sobre privatização passam por aí... A água se torna mercadoria, e as questões de compensações e de distribuição perdem força.

AMAURI: Sim, trata-se a água como mercadoria e não como direito.
CAROLINA: É aonde eu queria chegar.

AMAURI: A água é um direito humano. Vários países têm esse conceito na constituição. No Brasil, esse direito não está explicitado na Constituição, então...

CAROLINA: Eu penso que há formas mais justas e menos justas de circulação dessa mercadoria, mas um centavo por m®? Não sou capaz de avaliar quanto isso significa, mas é um centavo por $\mathrm{m \bigotimes}$, é isso?

AMAURI: Aproximadamente.

CAROLINA: Como o comitê pode ser valorizado, se não há recurso para pôr em prática suas ideias? Se o FEHIDRO fosse um recurso parrudo para implantação de melhorias, seria uma forma mais justa de...

AMAURI: Sim. A minha dissertação trata da aplicação dos recursos do FEHIDRO nas áreas de mananciais do Alto Tietê. Essa é minha investigação. A verdade é que o FEHIDRO não resolve tudo, que o recurso não é expressivo. Mostrei para você o projeto de recuperação do Areião: 3.200 famílias, custo de 276 milhões. O projeto é ótimo, ideal para todo mundo, a comunidade aprovou. Vamos arredondar: 300 milhões para fazer uma urbanização para 3 mil pessoas. O valor do FEHIDRO disponível no comitê do Alto Tietê é de aproximadamente 45 milhões anuais.

CAROLINA: Ordem de grandeza...

AMAURI: Seria preciso arrecadar durante 10 anos para realizar um programa de recuperação daquele porte. Mesmo que a arrecadação fosse duplicada, o valor chegaria a 80 milhões, não resolveria as 
questões da bacia do Alto Tietê.

CAROLINA: Dá para pagar o projeto, os técnicos.

AMAURI: Já é alguma coisa.

CAROLINA: Projeto é futuro, certo?

AMAURI: O que o FEHIDRO pode fazer? Pode ser um agente mentor ou de amarração de projetos, em vez de ter atuação pontual, sem foco, digamos, espraiada por toda a área dos mananciais sem obter um resultado efetivo. Talvez numa sub-bacia piloto, talvez fazer uma amarração dos projetos de habitação, saneamento, mobilidade, tudo num projeto só... É disso que trata minha dissertação.

CAROLINA: Qual é seu prazo?

AMAURI: Eu tenho que finalizar até agosto, mas pretendo finalizar em junho, julho no máximo.

CAROLINA: Também queria perguntar para você como funciona o DAEE? Qual a relação do DAEE com...

AMAURI: O DAEE é uma autarquia subordinada à secretaria de Saneamento e Recursos Hídricos, que agora se chama secretaria de Infraestrutura e Meio Ambiente. O DAEE se formou nos anos 1950. É uma autarquia que basicamente controla as outorgas de uso, trabalha muito com a quantidade de água.

CAROLINA: No caso da Prainha, por exemplo, a prefeitura atualmente administra a área, mas é uma outorga que alguém...

AMAURI: No caso da Prainha, não. A EMAE tem a propriedade da área até 50 metros da cota 747 da Billings...

CAROLINA: Sim, a 747.

AMAURI: Então, ela tem a propriedade, e a concessão é administrada pela ANEEL, Agência Nacional de Energia Elétrica; a EMAE tem a outorga, mas não pelo DAEE.

CAROLINA: Não há título de propriedade para as pessoas, certo?

AMAURI: A EMAE pode dar comodato. Por exemplo, os restaurantes que estão lá devem ter comodato. Para fazer aquele pier, a EMAE também forneceu um comodato. Não sei se foi para a prefeitura ou para a iniciativa privada, mas com certeza existe o instrumento de comodato. O espaço é cedido desde que não se faça nenhuma edificação, que se preserve a água, tem uma série...

CAROLINA: Então, é da EMAE, não é do DAEE.

AMAURI: É como se fosse um contrato particular da EMAE com terceiros.

CAROLINA: A mesma coisa no Cantinho do Céu? Foi um comodato dado pela EMAE para a prefeitura?

AMAURI: Do ponto de vista fundiário, foi um processo de licenciamento ambiental. Na verdade, não foi um comodato, foi uma autorização. Foi um documento oficial da EMAE que autorizava a prefeitura a implementar o parque, a utilizar a área. Isso dá para investigar na EMAE. O próprio Edson Escames pode apontar quem cuida disso hoje. A EMAE está quase em processo de extinção, assim como o DAEE; são 
órgãos quase extintos.

CAROLINA: E sobe tudo para essa supersecretaria de Infraestrutura?

AMAURI: Exato.

CAROLINA: É o novo modelito verão 2019.

AMAURI: Junte tudo e não faça nada. Você quer que eu copie o meu artigo?

CAROLINA: Eu quero, por favor.

CAROLINA: Obrigada. A Sabesp também está no comitê?

AMAURI: Sim, como representante do estado.

CAROLINA: O município de São Bernardo pode solicitar os recursos do FEHIDRO de alguma maneira?

AMAURI: Pode, qualquer município pode.

CAROLINA: Encaminha-se uma solicitação ao comitê, avalia-se etc. Tenho algumas perguntas mais políticas, por exemplo, quanto às transformações que aconteceram na Sabesp com a abertura de capital. Há quem diga que a capacidade de investimento da empresa aumentou significativamente.

AMAURI: Sim, há estudos que mostram isso.

CAROLINA: Mas, por outro lado, houve uma mudança simbólica no status da água.
AMAURI: A Sabesp trabalha com o "negócio água".

CAROLINA: Mais uma coisa: não faria sentido o comitê incorporar, como repertório para mananciais, as infraestruturas verdes?

AMAURI: Sim. Um colega meu está fazendo uma tese de doutorado sobre isso. Ele está analisando locais em que infraestruturas verdes foram implantadas: Equador, Holanda, Nova Iorque... Inclusive ele trabalha no Semasa de Santo André.

CAROLINA: Acho que é a forma mais econômica de fazer tratamento de água pluvial.

AMAURI: Sim, e seria economicamente razoável implantar infraestruturas verdes nas áreas de mananciais. Esse é o tipo de projeto com que o FEHIDRO poderia trabalhar. Escolher uma área piloto e avaliar os efeitos.

CAROLINA: Um processo controlado.

AMAURI: Mas, para isso, precisa "abrir a cabeça" de certas pessoas que controlam o FEHIDRO. 
